THE WESTERN QUESTION

IN GREECE AND TURKEY

\title{
A STUDY IN THE CONTACT OF CIVILISATIONS
}

\section{BY}

ARNOLD J. TOYNBEE

'For we are also His offspring'

CONSTABLE AND COMPANY LTD

LONDON · BOMBAY · SYDNEY

1922 
TO

THE PRESIDENT AND FACULTY OF THE

AMERICAN COLLEGE FOR GIRLS AT CONSTANTINOPLE

THIS BOOK IS DEDICATED BY

THE AUTHOR AND HIS WIFE

IN GRATITUDE FOR THEIR HOSPITALITY

AND IN ADMIRATION OF THEIR NEUTRAL-MINDEDNESS

IN CIRCUMSTANCES IN WHICH NEUTRALITY IS

'HARD AND RARE' 


\section{PREFACE}

THIS book is an attempt to place certain recent events in the Near and Middle East in their historical setting, and to illustrate from them several new features of more enduring importance than the events themselves. It is not a discussion of what the peace-settlement in the East ought to be, for the possibility of imposing a cut-and-dried scheme, if it ever really existed, was destroyed by the landing of the Greek troops at Smyrna in May 1919. At any rate, from that moment the situation resolved itself into a conflict of forces beyond control; the Treaty of Sèvres was still-born; and subsequent conferences and agreements, however imposing, have had and are likely to have no more than a partial and temporary effect. On the other hand, there have been real changes in the attitude of the Western public towards their Governments' Eastern policies, which have produced corresponding changes in those policies themselves; and the Greeks and Turks have appeared in unfamiliar roles. The Greeks have shown the same unfitness as the Turks for governing a mixed population. The Turks, in their turn, have become exponents of the political nationalism of the West. The break-up of the Ottoman Empire has been arrested at the borders of Anatolia, where Turkey has asserted her independence as successfully as her former Near Eastern subjects have asserted theirs in the Balkan Peninsula; and in this last stage in the redistribution of Near and Middle Eastern territories, the atrocities which have accompanied it from the beginning have been revealed in their true light, as crimes incidental to an abnormal process, which all parties have committed in turn, and not as the peculiar practice of one denomination or nationality. Finally, 
the masterful influence of our Western form of society upon people of other civilisations can be discerned beneath the new phenomena and the old, omnipresent and indefatigable in creation and destruction, like some gigantic force of nature.

Personally, I am convinced that these subjects are worth studying, apart from the momentary sensations and quandaries of diplomacy and war which are given more prominence in the Press, and this for students of human affairs who have no personal or even national concern in the Eastern Question. The contact of civilisations has always been, and will always continue to be, a ruling factor in human progress and failure. I am, of course, aware that the illustrations which I have chosen involve burning question, and that my presentation of them will not pass unchallenged. Indeed, the comparatively few people interested in disproving or confirming my statements may be my chief or only readers. I had therefore better mention such qualifications as I possess for writing this book.

I have had certain opportunities for first-hand study of Greek and Turkish affairs. Just before the Balkan Wars, I spent nine months (November 1911 to August 1912) travelling on foot through the old territories of Greece, as well as in Krete and the Athos Peninsula, and through my main interest was the historical geography of the country, I learnt a good deal about the social and economic life of the modern population. During the European War, I edited, under the direction 
of Lord Bryce, ${ }^{1}$ the Blue Book published by the British Government on the 'Treatment of Armenians in the Ottoman Empire: 1915' (Miscellaneous No. 31, 1916), and incidentally learnt, I believe, nearly all that there is to be learnt to the discredit of the Turkish nation and of their rule over other peoples. Afterwards I worked, always on Turkish affairs, in the Intelligence Bureau of the Department of Information (May 1917 to May 1918); in the Political Intelligence Department of the Foreign Office (May to December 1918); and in the Foreign Office section of the British Delegation to the Peace Conference at Paris (December 1918 to April 1919). Since the beginning of the 1919-20 Session, I have had the honour to hold the Koraís Chair of Byzantine and Modern Greek Language, Literature, and History, in the University of London; and on the $20^{\text {th }}$ October $1920^{1}$ the Senate of the University kindly granted me leave of absence abroad for two terms, in order to enable me to pursue the studies connected with my Chair by travel in Greek lands. I arrived at Athens from England on the $15^{\text {th }}$ January 1921 , and left Constantinople for England on the $15^{\text {th }}$ September. During the intervening time, I saw all that I could of the situation from both the Greek and the Turkish point of view, in various parts of the two countries. The most important of my journeys and other experiences were shared by my wife, and I have profited more than I can say by constant discussion with her of all that we saw and did together,

\footnotetext{
${ }^{1}$ Whose death has removed one of the most experienced and distinguished Western students of Near and Middle Eastern questions, though this was only one among his manifold interests and activities.

${ }^{1}$ Just a month before the change of government and consequent crisis in Greece, which I (like most other observers at a distance) had not foreseen.
} 
though I alone am responsible for the verification and presentation of the results of our observations.

My itinerary was as follows: ${ }^{2}$

(a) Jan. 15-26: Athens;

(b) Jan. 27 - March 15: Smyrna, and the following journeys into the hinterland:

1. Feb. 1-8: Alashehir, Ushaq, Kula, Salyhly, Sardis;

2. Feb. 11-18: Ephesus, Kirkinjé, Aidin, Tiré, Torbaly;

3. Feb. 26-March 10: Manysa, Soma, Kinik, Bergama, Yukhara Bey Keui, Aivali, Dikeli;

(c) March 17-Aug. 2: Constantinople, and the following journeys into the hinterland:

1. March 27-April 5: Brusa, Pazarjyk, Kovalyja, Nazyf Pasha, Yenishehir, Köprü Hissar;

2. April 7-13: Brusa, Gemlik, Ermeni Sölös;

3. May 24-25: Yalova;

4. June 2-6: Gemlik, Ömer Bey, Yalova;

5. June 13-18: Gemlik, Omer Bey, Armudlu;

6. June 22-27: Armudlu, Gemlik;

7. June 27-July 3: Ismid, Baghchejik, Karamursal, Eregli, Deirmenderé;

\footnotetext{
${ }^{2}$ The route is plotted out on the map at the end of the volume.
} 
(d) Aug. 3-8: Smyrna;

(e) Aug. 9-Sept. 1: Athens, and the following journey into the hinterland:

Aug. 16-26: Tripolitsa, Sparta, Mistrá, Trýpi, Kalamáta, Vurkáno, Mavrommáti, Meligalá, Isari, Astála, Kokolétri, Bassae, Pavlitsa, Kyparissía, Samikó, Olympia, and back via the Pyrgos-PatrasKorinth railway;

(f) Sept. 1-9: Athens to Constantinople via Lárisa and Salonika, with an excursion to Flórina, Kozháni, and Shátishta;

(g) Sept. 9-16: Constantinople.

My wife arrived at Constantinople, a few days before me, in March and started home by sea from the Peiraeus on the $15^{\text {th }}$ of August. Between those dates we were travelling together.

This summary will indicate what facts I am in a position to know, and it is for readers to judge whether I have presented them impartially and drawn fair conclusions. When a writer passes from statements of fact to judgments of right and wrong, his propositions become doubly controversial. But the observer of any conflict is bound to form moral judgments in the process of informing himself about events, and to abstract the one from the other, though it may give the appearance of scientific objectivity, is really less scientific than to put all his cards on the table. I have therefore expressed freely, though carefully, my judgments of right as well as of fact, and I submit that I am not convicted of partiality by the 
fact that, in discussing particular chapters of a long story, I sum up against one party in favour of the other. If that disqualifies me, then every verdict must be accounted a miscarriage of justice. The fact that I am neither a Greek nor a Turk perhaps creates little presumption of my being fair-minded, for Western partisans of non-Western peoples are often more fanatical than their favourites. I hope that it will appear from my method of treatment that my own interest in Greece and Turkey arises from curiosity (the most respectable of human motives), and that I am as much interested in their past, about which it is futile to break lances, as in their present and future.

It may, I fear, be painful to Greeks and 'Philhellenes' that information and reflections unfavourable to Greece should have been published by the first occupant of the Koraís Chair. I naturally regret this, but from the academic point of view it is less unfortunate than if my conclusions on the Anatolian Question had been favourable to Greece and unfavourable to Turkey. The actual circumstances, whatever personal unpleasantness they may entail for me and my Greek friends and acquaintances, at least preclude the suspicion that an endowment of learning in a British University has been used for propaganda on behalf of the country with which it is concerned. Such a contention, if it could be urged, would be serious; for academic study should have no political purpose, although, when its subject is history, its judgments upon the nature and causal connection of past events do occasionally and incidentally have some effect upon the present and the future. 
In this connection I ought to add that I made my journeys in 1921 as special correspondent for the Manchester Guardian, ${ }^{1}$ and to mention the reasons. I did so first in order to pay my expenses; secondly, because the Guardian is a paper which it is an honour to serve; and thirdly, because without this status it would hardly have been possible for me to learn what I wanted. My travels coincided with a historical crisis; and, during such crisis, travelers like myself who are not persons of eminence have little chance of meeting the important people and witnessing the important events, if they travel as students or tourists; while journalists, however unimportant personally, have greater opportunities in such circumstances than under normal conditions.

\section{ARNOLD J. TOYNBEE.}

London, $22^{\text {nd }}$ March 1922.

\footnotetext{
${ }^{1}$ The sketches appended to Chapters IV.-VII. were originally published in the Manchester
} 


\section{NOTE ON SPELLING}

I CANNOT pretend that my spelling of Greek and Turkish proper names, of which this book is full, has been consistent, though I have been careful always to spell the same name in the same way-except in quotations, where I have purposely left the names as they stand. I have used the following symbols:

(i) In Turkish words-

$$
\begin{aligned}
& \text { ‘='ain (impossible to transliterate into the Roman alphabet). } \\
& \text { '=hemzé (a hiatus in the middle of a word). }{ }^{1} \\
& \text { gh=ghain (like the German gutteral } g \text { ). } \\
& \text { q=qaf (hard } k \text { ). }
\end{aligned}
$$

$y$ (when a vowel)=hard yé or hard esseré (something like the $u$ in English 'until' when rapidly pronounced).

other unmodified $\quad\}=$

vowels $\quad\}=$ Italian vowels.

Gardian, and are reprinted here by the kind permission of the Editor.

${ }^{1}$ Except in the proelision of the Arabic definite article (e.g. in 'Abdu'l-Hamid'), which I have indicated by using this sign in the ordinary English way. 
modified vowels=German modified vowels.

(ii) In Greek words-

gh=hard gamma (like ghain).

consonantal $y=$ soft gamma.

$\mathrm{dh}=\mathrm{dhelta}$ (like the th in English 'the')

th=thita (like the th in English 'thin').

$s=$ sigma (like $s$ in English 'this,' but never like $s$ in English 'his').

kh=khi (like $c h$ in Scotch 'loch').

(ii) In Greek words-continued.

$\mathrm{x}=\mathrm{ksi}$ (like $x$ in 'axe,' but never like $x$ in English 'examine').

ph=phi $($ English $f)$.

vowels (as written \}

in this book) $\quad\}=$ Italian vowels

I have often indicated the Greek stress accent, which is as puzzling as the Russian.

However, I have not gone to extremes. In fact, I have hardly used ',', or $q$ at all (the latter only, I think, in 'Saljuq' and 'Ushaq,' which have somehow impressed themselves on my mind in those forms). On the other hand, I have always used vowel $y$ for Turkish hard $i$, except in words familiarly spelt otherwise—e.g. 'Aidin' and 'Osmanli.' To write 'Uthmanly' would be misleading as well as affected. 


\section{TABLE OF CONTENTS}

CHAP.

PAGE

PREFACE

vii

NOTE ON SPELLING Xiii

I. THE SHADOW OF THE WEST 1

$\begin{array}{ll}\text { II. WESTERN DIPLOMACY } & 37\end{array}$

III. GREECE AND TURKEY IN THE VICIOUS CIRCLE 63

IV. THE BACKGROUND IN ANATOLIA 107

$\begin{array}{ll}\text { TWO RUINED CITIES } & 148\end{array}$

V. GREEK AND TURKISH GOVERNMENT 153

A JOURNEY THROUGH THE MOUNTAINS 196

AN AGRICULTURAL EXPERIMENT 201

GREEK PRISONS AT SMYRNA 204

THE TURKISH NATIONAL PACT 207 


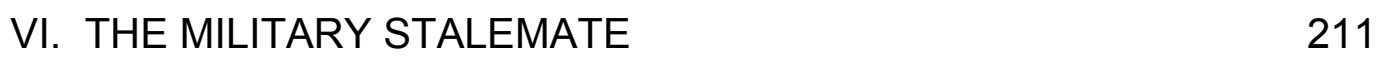

THE BATTLE OF IN ÖNÜ 246

THE ORIGIN OF A LEGEND 254

VII. THE WAR OF EXTERMINATION 259

$\begin{array}{ll}\text { YALOVA } & 299\end{array}$

THE AREA OF THE ORGANISED ATROCITIES 311

VIII. NEW FACTS AND OLD VIEWS 320

TABLE OF DATES 365

$\begin{array}{ll}\text { LIST OF BOOKS } & 371\end{array}$

$\begin{array}{ll}\text { ADDITIONAL NOTE ON CHAPTER V } & 387\end{array}$

ADDITIONAL NOTE ON CHAPTER VII 390

$\begin{array}{ll}\text { INDEX } & 406\end{array}$

MAPS

THE THEATRE OF WAR IN WESTERN ANATOLIA, folding

out at the end of Chapter VI 258

THE DANGER LINE OF ÖMER BEY 314

THE AUTHOR'S JOURNEYS IN 1921, folding out at the end of

the volume

420 


\section{THE SHADOW OF THE WEST}

SAVAGES are distressed at the waning of the moon and attempt to counteract it by magical remedies. They do not realise that the shadow which creeps forward till it blots out all but a fragment of the shining disc, is cast by their world. In much the same way we civilised people of the West glance with pity or contempt at our non-Western contemporaries lying under the shadow of some stronger power, which seems to paralyse their energies by depriving them of light. Generally we are too deeply engrosse in our own business to look closer, and we pass by on the other side-conjecturing (if our curiosity is sufficiently aroused to demand an explanation) that the shadow which oppresses these sickly forms is the ghost of their own past. Yet if we paused to examine that dim gigantic 
overshadowing figure standing, apparently unconscious, with its back to its victims, we should be startled to find that its features are ours.

The shadow upon the rest of humanity is cast by Western civilisation, but it is difficult for either party to comprehend the whole situation. The other human societies, or at any rate the civilised and educated people among them, are thoroughly aware of the penetrating and overpowering effect of the West upon their public and private life, but from this knowledge they draw a mistaken inference. In the Near and Middle East, for example, most observers are probably struck by the fact that their Greek and Turkish acquaintances, who differ about almost everything else, agree in the conviction that Western politics turn upon the Eastern Question, and that the Englishman or Frenchman looks abroad on the world with eyes inflamed by a passionate love or hatred, as the case may be, for the Greek or the Turkish nation. At first one is inclined to attribute this misconception purely to megalomania, and to shrug one's shoulders at it as being the kind of infirmity to which non-Western peoples are heir. Later, one realizes that, erroneous though it is, it arises from the correct understanding of an important fact regarding us which we ourselves are apt to overlook. Just because we are aware of what passes in our own minds, and know that interest in Eastern affairs is almost entirely absent from them, it is difficult for us to realise the profound influence on the East which we actually, though unconsciously, exercise. This conjunction of great effect on other people's lives with little interest in or intention with regard to them, though it is common enough in human life, is also one of the principal causes of human misfortunes; and the 
relationship described in my allegory cannot permanently continue. Either the overshadowing figure must turn its head, perceive the harm that unintentionally it has been doing, and move out of the light; or its victims, after vain attempts to arouse its attention and request it to change its posture, must stagger to their feet and stab it in the back.

It is worth examining these two features in our relationship to other civilisations which are so dangerous in combination. Our indifference-to start with that-is partly temporary, at any rate in its present degree of profundity. Interest in Eastern (as in other) foreign affairs was suddenly and artificially stimulated in all Western countries during the European War. The destinies of England, France, Germany, and even the United States were obviously affected then by the policy of the Greek, Ottoman, and other Eastern Government, and hundreds of thousands of English soldiers, and many thousand French, German, and Austrian soldiers, serving in the East, were constantly in the thoughts of their families at home. But the moment Turkey asked for an armistice and the bulk of the European expeditionary forces were drafted back and demobilised, this unusual interest died away and was followed by an access of apathy, also abnormal, which was partly due to war-weariness and partly to the pressure of more urgent post-war problems nearer home. Greece and Turkey have been pushed into the background by Silesia, the Coal Strike, Reparations, Ireland, the Pacific, Unemployment, and the rift in the Entente. During the eight months of 
$1921^{1}$ which I spent in Greece and Turkey, Greek and Turkish affairs only occupied the attention of Western statesmen or were given prominence in Western newspapers during the three weeks ${ }^{2}$ when a conference of Allied ministers, expressly convened to reconsider the Treaty of Sèvres, was sitting in London. But even on this special occasion the faint interest aroused was immediately eclipsed by a crisis in the relations between the three Entente Powers and Germany.

I generally found the Greeks and Turks incredulous when this was pointed out to them. They insisted (of course erroneously) that the immense effects which were being produced all the time in the East by Western action, must be the result of policy; it was inconceivable that they could be unintentional and unconscious; or at any rate the interest of the Western public was bound in the near future to be aroused by the striking consequences of its unconscious activity. The most effective way to combat this delusion was to remind them that the British public was almost apathetic about the violent disturbances which were then taking place in Ireland, a country next door to Great Britain, vitally affecting our security and actually under our government. Was it likely, then, that Great Britain was or would be interested in Near and Middle Eastern countries for which we had no direct responsibility and whose fate was of secondary concern to the British Empire?

$15^{\text {th }}$ Janaury to $16^{\text {th }}$ September.

${ }^{2} 21^{\text {st }}$ February to $12^{\text {th }}$ March. 
This extreme degree of indifference towards non-Western affairs is no doubt unlikely to be permanent; but in the lesser degree in which it has always existed, it will probably continue, because it is a natural state of mind. Western society is a unity-a closer and more permanent unity than either the independent states that form and dissolve within its boundaries or the Empires compounded of Western and non-Western populations—and its own internal affairs are bound to draw its attention away from the borderlands or the regions beyond them. Our English politics and economics are more closely concerned with the East than are those of any other Western nation, and yet English children at school are still taught French and German and not Hindustani and Arabic_-just because many more individual English people have relations with neighbouring Western nations than with our non-Western fellow-subjects overseas.

This historic Western indifference is strikingly illustrated by the policy of the Hapsburg Monarchy, a Western Power which had vital interests in the Eastern borderlands of our world and might have made its fortune, between A.D. 1699 and 1768, as heir to all the provinces of the Ottoman Empire on this side of Constantinople. Yet though, during this favourable period, the Austrian Government had at its disposal some of the best political talent in Europe, the Drang nach Osten was perpetually arrested and reversed by the attraction of the West. Even to the most sharp-sighted statesmen at Vienna, a province in Germany or Italy looked as large and as desirable as a kingdom in the Balkans. They expended their strength in the three great Western wars of the eighteenth 
century; Russia got ahead of them on the road to Constantinople; and then the spread of Western political ideas among the local nationalities closed the thoroughfare altogether. When Bismarck at last cut off the Austrian Eagle's Western head, and advised the bird to use the other, it was too late. The optical illusion which minimized Eastern and magnified Western objectives in the eyes of eighteenth-century Austrian statesmen, is possibly the principal cause of the break-up of that ancient Western Monarchy in our own generation, and it is certainly characteristic of the permanent attitude of the Western public.

In dramatic contrast to this indifference is the actual influence on Eastern life which the West has long exerted. On the Near and Middle East, at any rate, where the superior vitality and effectiveness of Western civilisation are reinforced by proximity, our influence has been increasing during the last two and a half centuries till it is actually paramount there, while we have remained hardly conscious of a process which now impresses itself upon the local populations at every turn. This combination of maximum actual effect with minimum consciousness and interest has made the Western factor in the Near and Middle East on the whole an anarchic and destructive force, and at the same time it appears to be almost the only positive force in the field. Whenever one analyses a contemporary movement-political, economic, religious, or intellectual—in these societies, it nearly always turns out to be either a response to or a reaction against some Western stimulus. In some form, a Western stimulus is almost invariably there, and a purely internal initiative is rarely discoverable, perhaps even non-existent, the reason being that, before Western penetration began, the 
indigenous civilisations of these regions had partly or wholly broken down. A brief review of these break-downs is necessary for an understanding of the present situation, and in attempting it I can at the same time define my terms.

The term 'Near Eastern' is used in this book to denote the civilisation which grew up from among the ruins of Ancient Hellenic or Graeco-Roman civilisation in Anatolia and at Constantinople, simultaneously with the growth of our civilisation in the West. The two societies had a common parent, were of the same age, and showed the same initial power of expansion, but here the parallel ends. Western civilisation (whatever its ultimate limitations) has so far continued to progress and expand, while Near Eastern civilisation, after a more brilliant opening, broke down unexpectedly in the eleventh century after Christ, and fell into an incurable decline, until, about the seventeenth century, its influence over men's minds became extinct, except in Russia.

The cause of this break-down — to state it briefly and roughly—was the premature development of the Near Eastern state, which reached an efficiency at the very beginning, in the eighth century, which the Western state did not attain until the close of the fifteenth. ${ }^{1}$ This overgrowth of a particular social organ had two fatal effects. First, it stunted or arrested the growth of other social institutions and activities. The Church became a department of state in the various Near Eastern monarchies, not, as in the West, an institution transcending states and

\footnotetext{
${ }^{1}$ Except in the city-states of Northern and Central Italy, where during the fourteenth and fifteenth centuries miniature samples of the modern Western 'Great Power' were grown experimentally, like seedlings in a nursery-garden.
} 
binding a civilisation together; monastic orders, boroughs, marches, bishoprics, and universities never struggled into autonomy, and only the rudiments of new vernacular literatures appeared. The state absorbed or subordinated all, and so there was nothing to mediate between one state and another. The 'East Roman' (that is, the mediaeval Greek) and the Bulgarian Empires, each claiming to be a complete embodiment not only of the political but of the ecclesiastical and spiritual life of Near Eastern civilisation, were incompatible. There was no room for both in the Near Eastern world, and the fatal consequence was the Hundred Years' War (A.D. 913-1019) between these two principal Near Eastern Powers, which resulted in the temporary subjection of mediaeval Bulgaria and the exhaustion of mediaeval Greece. The victorious empire-militarised, distended, and overstrained—became an easy prey to its neighbours, and Near Eastern civilisation, which it had pressed altogether into its service, fell with it.

The inroads of the Central Asian nomads upon Eastern and Central Anatolia in the eleventh century are discussed in Chapter IV., but the first general conquest of Near Eastern society by another came from the West. Near relations are not always the best friends, and any one who reads Liutprand of Cremona's memoir of his embassy to the court of Constantinople ${ }^{1}$ (A.D. 968) or Anna Comnena's description of the First Crusade (A.D. 1096-7), ${ }^{2}$ will be

\footnotetext{
${ }^{1}$ New edition by Becker, J. (Hanover, 1915, Hahn), of Pertz's edition in the Monumenta Germ. Hist., vol. iii.

${ }^{2}$ Annae Comnenae Alexias, ed. Reifferscheid, J. (Leipzig, 1884, Teubner, 2 vols.).
} 
impressed by the mutual antipathy of the Near East and the West at their first encounters.

The Western conquest (begun by the Norman invasions, and completed at the beginning of the thirteenth century by the Fourth Crusade) naturally increased and embittered this antipathy on the Near Eastern side, and hatred of the 'Latins' materially assisted the later and more thorough conquest of the Near Eastern world for Middle Eastern civilisation by the Osmanlis (fourteenth and fifteenth centuries after Christ). On the eve of the capture of Constantinople by the Ottoman Power, 'the first minister of the [East Roman] Empire...was heard to declare that he had rather behold, in Constantinople, the turban of Mahomet than the Pope's tiara or a cardinal's hat'; ${ }^{3}$ and while the submergence of Near Eastern society was naturally accompanied by a general heightening of consciousness among its members of their difference from other civilised communities, the memories of Western domination seem to have overshadowed the actualities of Middle Eastern for at least two centuries. At any rate, down to the middle of the seventeenth century the Near East on the whole displayed greater hostility towards Western than towards Middle Eastern influences.

The exception which proved the rule, while also pointing towards an approaching mental revolution, was the career of Cyril Lukaris. This exceptional man was a Greek and a priest of the Orthodox Church who went westward to study in Venice and Padua, pushed on to Geneva, and (without leaving his own

\footnotetext{
${ }^{3}$ Gibbon, Decline and Fall, ch. Ixviii.
} 
Church) came under the spell of Calvinism. His character and his Western education carried him to the highest positions. In 1602 he was elected Patriarch of Alexandria, in 1621 of Constantinople. He held the Oecumenical Patriarchate for sixteen years; sent numbers of young Greeks to study in the Protestant Universities of Western Europe; and published a Confession of Faith (adapting Calvanistic ideas to Orthodox theological terminology) not only in Greek butsignificant innovation—in simultaneous French, Latin, German, and English editions. And then he fell. The Near Eastern hatred of the West-even when represented by Western opponents of the Roman Church—was stronger than Lukaris's genius. His enemies persuaded the Ottoman Government in 1637 to have him executed as a dangerous innovator, and his doctrine was finally condemned by an Orthodox synod in $1691{ }^{1}$

By that date, however, the mental reorientation of the Near East towards the West was in full swing. The 'Westernisation' of the Near Eastern world is one of the most remarkable phenomena in the intercourse between different civilisations. It appears to have begun rather suddenly in the same generationabout the third quarter of the seventeenth century—among both the Russians and the Greeks, and among the latter, where there was no 'enlightened monarch' like Peter the Great to give it an impulsion, its origins are more mysterious and more interesting. No doubt it was encouraged by the contemporary tendency in the West towards religious toleration, which was at last making Western culture

\footnotetext{
${ }^{1}$ The Roman Catholic missionaries in the Levant were his enemies as well as the anti-Western
} 
accessible without the necessity of accepting some variety of Western religious dogma. At any rate, a movement began among Near Easterners of that generation which will have far more momentous results than the commercial, diplomatic, and military rivalries of Western Powers in the Levant, for which the name of 'Eastern Question' is commonly reserved. The Near East saw its Western neighbours in a new light, no longer as the barbarian Franks, but as 'Enlightened Europe' (a phrase that constantly recurs in he writings of Koraís), and it adopted Western clothes and manners, Western commercial and administrative methods, and above all Western ideas. Western literature was translated, was imitated, and was able to propagate new branches in the Near Eastern vernaculars, which had failed in the Middle Ages to produce a literature of their own. For the last two and a half centuries, the Near East, having lost its distinctive civilisation, has flung itself into the Western movement with hardly any reserves or inhibitions.

Middle Eastern civilisation has broken down in a different way and with different consequences. In this book the term 'Middle Eastern' is used to denote the civilisation which has grown up from among the ruins of the ancient civilisations of Egypt and Mesopotamia. Its parentage is not the same as ours, and it is not our contemporary but our junior by about six centuries. The interregnum, accompanied by barbarian invasions, between the breakdown of Hellenic or Graeco-Roman civilisation and the beginnings of the modern West occurred approximately between the years A.D. 375 and 675 , while the similar 
interregnum, preceding the birth of the modern Middle East, when the Abbasid Empire broke down and the Egyptian and Mesopotamian world was overrun by Turkish and Mongol nomads and Western Crusaders, did not begin till the tenth century A.C. and was hardly over by the close of the thirteenth. The new civilisation which was emerging by the date A.D. 1300 had a not unpromising beginning. There was practical genius in the political and military organisation of the early Ottoman Empire; religious fervour in the Shi'l revival in Persia; architectural beauty in such buildings as the Great Mosque at Ephesus, the Green Mosque at Brusa, the Mosque of Sultan Ahmed at Constantinople, or the Taj Mahal at Agra, which range from the close of our thirteenth to the middle of our seventeenth century. Yet the break-down in Middle Eastern civilisation began at an earlier stage than in Near Eastern. In both the Ottoman and the Indian ${ }^{1}$ Empire, the decline of vitality and creative power was perceptible by the close of the sixteenth century, only about three hundred years from birth; and by A.D. 1774 the Mogul Power in India and the Safawi Power in Persia had perished, while the Ottoman Power seemed to be in its death agony.

Two causes of this Middle Eastern break-down suggest themselves, one connected with the design of the new building, the other with the site on which it was laid out. Middle Eastern institutions, which were worked out most logically in

\footnotetext{
${ }^{1}$ The Mogul dynasty, which did not really secure its hold over Northern India till the beginning of Akbar's reign (A.D. 1556), was only the last and outwardly most magnificent phase of a Moslem state in Northern India which had a continuous history, in spite of changes of dynasty and other vicissitudes, from the conquests of Muhammad Ghori in the last decade of the twelfth century after Christ onwards.
} 
the Ottoman Empire and somewhat less systematically in Northern India, did not lack originality. The selection, education, and life-long discipline of soldiers and officials were as audaciously conceived in the Empire of Muhammad the Conquerer as in the imaginary Republic of Plato, ${ }^{2}$ but they were equally contrary to nature. The new institutions were a thorough-going adaptation to sedentary conditions of the nomad economy which had enabled the ancestors of the Moguls and Osmanlis to make a livelihood on the steppes, and the relations between ruler, servants, and subjects were modeled on those between shepherd, watch-dog, and herd. The system could hardly have survived even if the populations on whom the founders of the new order imposed it had been characterless and impressionable, for the Osmanli watch-dogs rebelled against their Sultan's regulations long before the Near Eastern rayah ${ }^{1}$ challenged the watch-dogs' control. But the principal experiments in this system happened to be made in areas where other civilisations, or at least the ruins of other civilisations, already covered the ground, and this was certainly the second cause of failure. It is not difficult to see why the new civilisation attempted to develop in Northern India and in the Near East. The old centres of Mesopotamian and Egyptian civilisation were exhausted. Persia and Iraq had been trampled down by the first sweep of the nomadic invasions in the interregnum, Syria and Egypt broken by resistance on two fronts, to the Crusaders and the Mongols. It also seems to be

\footnotetext{
${ }^{2}$ See Lybyer, A. H., Government of the Ottoman Empire in the Time of Suleiman the Magnificent (Harvard, 1913, University Press), and compare Lane-Poole, S., Mediaeval India (London, 1903, Fisher Unwin), for the slave system of Firoz Shah of Delhi, in the fourteenth century after Christ.
} 
a law of history that every death, interregnum, and rebirth of civilisation is accompanied by a change of locality. Modern Western civilisation made its first progress not in Greece and Southern Italy, which had nurtured its parent, but on the almost virgin soil of outlying provinces of the Roman Empire; and even Near Eastern civilisation started, away from the centres of Ancient Greek culture, in inner Anatolia, and expanded among the unsophisticated Slavs. But the sites which fell to Middle Eastern civilisation were not untenanted, though its own principal parent had not been the occupant. To conquer and assimilate such venerable, self-conscious, and exclusive societies as the Near Eastern and the Hindu was a difficult enterprise for any young civilisation, and the proximity of Western civilisation, rising towards its prime, made the attempt dangerous. The early break-down of the nomadic institutions was neither surprising nor necessarily fatal in itself. The Teutonic institutions with which the West made its first experiments in construction were equally unsuccessful, yet the failure of the Carolingian system did not kill the new Western civilisation which had begun to develop within that framework. It has lived to build itself a whole series of political mansions. The parallel breakdown in the modern Middle East was less easy to repair because it laid bare the old ruins on the site which had not been worked into the new plan, and set free their original tenants to reconstruct them on the quite different and more attractive Western model.

This 'Westernisation' of the Near East has been discussed above, but it is important to note that the break-down of Middle Eastern civilisation, which helped

\footnotetext{
1 'Cattle.'
} 
to make it possible, has only been partial. Civilisations, like individuals, spring from two parents, and in all new civilisations whose parentage we can trace, the heritage from the civilised mother has been more important than that from the barbarian who violated her. In the West, the Near East, and the Middle East alike, this heritage from the mother civilisation has been handed down in the form of 'universal religions'-Christian churches in the two former cases, Islam in the other. Just as the Western Church survived the failure of the early Teutonic kingdoms, so Islam has survived the collapse of the Mogul and Osmanli Powers. Moreover, because modern Middle Eastern civilisation is six centuries younger than ours, Islam is still a greater force in its world than Christianity now is among us. As an expression of emotions and ideas and as a bond of society, it is at least as powerful as Christianity was in the West in the fourteenth century, and even more indispensable—for in the Middle East no new secular structure has yet been successfully erected, the submerged Hindus and Near Easterners have lifted their horns, and the West has trespassed through the ruined walls. Islam, and nothing but Islam, now holds the Middle Eastern world together.

These considerations explain the difference between the two processes of 'Westernisation' in the Middle East and the Near East which are observable in our generation. The process in the Near East began about 250 years ago and has gone forward fairly smoothly and easily, because the positive previous obstacles had already been removed. In the Middle East it did not begin till a century later. It first manifested itself in the Ottoman Empire after the disastrous Treaty of Kuchuk Kainarjy, imposed by Russia in 1774, and it has been 
constantly retarded and interrupted by the real presence of Islam. In fact, though the Ottoman Empire, by adopting Western methods, has achieved what seemed impossible a century and a half ago and has survived-even though with diminished territory and sovereignty—until our day, it has never so far gone much beyond the minimum degree of Westernisation necessary to save it, at any given moment, from going under. It has borrowed more technique than ideas, more military technique than administrative, more administrative than economic and educational. Thus, if Westernisation were in itself the summum bonum for nonWestern peoples, the Middle Eastern world, just because it is not a tabula rasa, would be a less promising field than the Near Eastern world for the advancement of humanity. But any such notion, though flattering and therefore plausible to Western minds, is surely improbable. Middle Eastern civilisation, while in many respects obviously less successful than ours, is also likely to contain valuable different possibilities, and its disappearance would be a loss, as the disappearance of a distinctive Near Eastern civilisation in South-Eastern Europe has proved to be already. The practical certainty, therefore, that the 'Westernisation,' like the break-down, of the Middle East will only be partial, is a gain and not a calamity. It would only be disastrous if the Islamic element in Middle Eastern civilisation and the constructive element in contemporary Western life were incompatible, for then the survival of Islam in the Middle East might certainly wreck the development of Middle Eastern society and involve our two worlds in an irreconcilable conflict. But this incompatibility, though often asserted, is disproved by the modus vivendi between Islam and the Western 
spirit which the Middle Eastern peoples have been working out, in their internal life as well as in their relations with Western countries, during the last 150 years. Their problem is more complicated than that of their Near Eastern neighbours, it will take longer to solve, and they have begun a century later. But it is certainly not insoluble, and if and when the modus vivendi is completed, it may have more fruitful results than are to be expected from the more thorough-going assimilation of the Near East to the Western character.

Moreover, when the difference between the processes of Westernisation in the Near and the Middle East has been given full consideration, the fact remains that both societies are moving along the same road in the same direction. It would be out of place to digress further here in order to demonstrate this proposition. It is a postulate of this book. It will meet with opposition, partly through prejudice and partly because it is easier to regard objects of thought as constants than as variables. One slips into thinking of Western, Near Eastern, and Middle Eastern civilisation as each something with an unchanging identity, and from this it is only a step to assume that because the Near East is at this moment nearer than the Middle East to the West, it is therefore somehow a priori within the Western pale, and the Middle East permanently outside it. It is more difficult to bear in mind that none of the three are stationary, and that while the Near and Middle East are both approaching the West, at different rates and intervals and from different angles, the West is all the time moving on a course of its own. Yet relativity is as fundamental a law in human life as it now appears to 
be in the physical universe, and when it is ignored, a true understanding of past history or contemporary politics ceases to be possible.

When one turns from generalizations to instances, it becomes clearer that the phenomena produced respectively by the contact with the Middle East and the Near East with the West have more resemblances than differences. As we look into the recent problems and struggles of each of these societies, we find the same necessity to borrow from the West and the same destructive initial consequences. On the one hand, the survival of Near and Middle Eastern communities, after the break-down of their own forms of life and in the face of Western expansion, has only been made possible by the adoption of certain Western elements. The present Greek National State could never have been built up, as it has been since 1821 , if during the preceding century numbers of Greeks had not acquired Western commercial methods and educational ideals. Again, the Ottoman Empire could never have survived the apparently desperate crisis of 1774-1841, during which its indigenous institutions finally broke down and its existence was threatened by Russia, the Greek Revolution, and Mehmed Ali, if it had not taken over successfully a modicum of Western military and administrative technique. Yet all the time this infusion of Western life, which was essential to the peoples that experienced it and was welcomed and brought about by these peoples deliberately because they recognised that it was the alternative to going under, has worked havoc with their lives. It has been new wine poured suddenly and clumsily into old bottles. 
This is equally true of ideas, institutions, and intellectual activities-for example, the Western political idea of nationality. The Near and Middle Eastern peoples had to reorganize themselves on national lines if they were to hold their own at all in modern international politics, because nationality is the contemporary basis of Western states and, owing to the ascendancy of the West in the world, the relations of non-Western peoples to each other and to Western Powers have to approximate to the forms which the Western world takes for granted. Yet this principle of nationality in politics is taken for granted by us simply because it has grown naturally out of our special conditions, not because it is of universal application. The doctrine really is that a sovereign independent territorial state ought to be constituted, as far as possible, of all and none but the speakers of a single vernacular. The existence of a French-speaking population implies for us an 'all-French' sovereign national state, an English-speaking population an English one, and so on. This is common-sense in Western Europe, where languages are on the whole distributed in homogeneous territorial blocks, corresponding to convenient political units. The Western national state has grown up among us because it has brought with it the maximum political efficiency and economy of effort possible for our world, and since it has grown and has not been manufactured, it has accommodated itself to other political realities and not asserted itself à outrance. The survival of Switzerland and Belgium, whose unity is real but not linguistic, is evidence of the political moderation and sanity of Western Europe. But the value of this nationality principle depends on the prevalence of solid blocks of 'homophone' population, a 
condition which is unusual in the homelands of civilisations, which are perpetually drawing into their focus fresh reinforcements of population from all quarters. No doubt this is the reason why no known civilisation except ours has made community of language the basis of political demarcation; and in this the Near and Middle East both conform to the general rule, while we are exceptions.

In the Near and Middle East (at any rate since their contact with the West began) populations speaking different languages have been intermixed geographically, and do not represent local groups capable of independent political life so much as different economic classes whose co-operation is necessary to the well-being of any local state. The introduction of the Western formula among these people has therefore resulted in massacre. The formula has been rigidly applied, because it has had no local history behind it, and local institutions, which might have modified it, had already broken down. It has been applied more and more savagely as it has exacted its toll of suffering and exasperation. The Greek War of Independence, which was perhaps the first movement in this region produced by a conscious application of the Western national idea, ${ }^{1}$ occasioned massacres of Turks throughout the Morea and of Greeks at Aivali and in Khios. Even the nuclei of the Near Eastern national states, though formed in areas where some single nationality predominated, had to be carved out by procrustean methods, and the evil has increased since the

\footnotetext{
${ }^{1}$ The Serbs of course revolted earlier, but Serbian independence, though the influence of Western ideas was no doubt at work from the beginning, came about more by a gradual re-
} 
attempt to reorganize the political map on Western lines has been carried into districts where no single nationality is (or was) numerically preponderant. In the northeastern provinces of Turkey, the massacre of Armenians by Moslems has been endemic since 1895; in Macedonia the mutual massacre of Greeks, Bulgars, Serbs, and Albanians since about 1899; and after the Balkan Wars the plague of racial warfare spread—with the streams of Moslem refugees-from Macedonia to Thrace and Western Anatolia. In the latter country, a Greek and a Turkish population which had lived there side by side, on the whole peaceably, for at least five centuries-even during the wars between Greece and Turkey in $1821-9^{2}$ and in 1897 -have both been seized by fits of homicidal national hatred. It broke out among the local Turks in 1914 and 1916; among the local Greeks at the landing of the Greek Army in May 1919 and, since April 1921, all over the interior of the occupied territory, in parts of which my wife and I had personal experience of it during the May and June of that year. ${ }^{3}$ Such massacres are only the extreme form of a national struggle between mutually indispensable neighbours, instigated by this fatal Western idea, and carried on unremittingly by the other deadly weapons of expropriation, eviction, hostile interference with education and worship and the use of the mother-tongue, and the refusal of justice in courts of law. The recent history of Macedonia and Western Anatolia has been a reductio ad absurdum of the principle of nationality, and has made

grouping of certain indigenous forces in the Ottoman Empire. The movement was not so revolutionary, nor the Western idea so dominant, as in the Greek case.

${ }^{2}$ In Anatolia, in contrast to Rumili, the destruction of Greeks by Turks at Aivali in 1821 was exceptional.

${ }^{3}$ See Chapter VII. 
the Western public begin to see that there are limits to the application of it in nonWestern countries. But the historical interest of these limiting cases lies in the doubt which they cast back upon the fruitfulness of the principle even in those areas where, by hook or by crook, it has been made to work. The historian is led to speculate whether the inoculation of the East with nationalism has not from the beginning brought in diminishing returns of happiness and prosperity. Given the previous break-down of indigenous institutions and the irresistible ascendency of the West, he must admit that it has been inevitable. But when, after a century of waste and bloodshed, the resultant Jugoslav, Rumanian, Greek, Bulgarian, Albanian, Turkish, Arab, Armenian, Georgian, and other Near and Middle Eastern national states have reached (if they ever do reach) some stable equilibrium, he will possibly judge the movement of which they are a monument to have been not to much a political advance as a necessary evil.

Next, let us consider the Westerisation of some institution, like the Ottoman Army. The most important internal struggle in Turkey during the crisis of 1774-1841 was between would-be reformers of the army on Western lines and the interests vested in the lumber of the old, broken-down Osmanli system. Sultan Mahmud's principal achievement was that he got rid of the Janissaries during the Greek War of Independence and built up enough of a new model army to save Constantinople from the Russians in 1828-9. The formation of regional army corps on the Prussian model was carried out in 1843 , and universal service introduced for Moslems in 1880 and for Christian subjects of the Empire after the Revolution of 1908. The progressive Westernisation of the army has 
undoubtedly saved Turkey from extinction during the last century, and has made possible an unprecedented assertion of the Central Government's authority over unruly tribes and outlying provinces. The military schools for officers have also been a valuable instrument of national education. Yet these essential military reforms have almost been the death of the Turkish nation, because they have been introduced artificially and therefore in isolation from the contemporary advances in hygiene, administrative method, and official integrity, which, in the Western countries where universal service has grown up, have counteracted the dangers otherwise attaching to such a vast extension of state power over the life of an individual. The Turks had to mobilize, train and arm in Western fashion a large - too large — proportion of their able-bodied male population in order to preserve the Ottoman Empire's existence, and under this stimulus they mastered the means, but they never learnt to clothe these conscripts adequately, pay them regularly, look after their health, and demobilise them punctually after their proper term of service. Western efficiency was no more natural to nineteenth-century Turks in these spheres than in the sphere of pure military technique, and the necessity for it was less immediately obvious. Accordingly, for several generations the Turkish peasantry have been mobilized to die of neglect or mismanagement or to return home with broken health, perhaps carrying contagious diseases, to find their family dispersed or their property ruined. The drafts of soldiers from Anatolia, shipped off in Western-made uniforms and Western-built steamers to fight in Albania or the Yemen with hardly any of the arrangements for personal welfare which make such campaigns endurable for 
Western troops, were also victims of the fatal side of the contact between the Ottoman Empire and the West. Their Government was not capable of victimising them in this way before it borrowed the necessary minimum of Western technique. All that can be said is that the reduction of the Ottoman Empire to the territories inhabited by a Turkish majority (itself the result of a Western agency, the principle of nationality) may at last bring the Turkish peasant some relief. His antagonists will have unwittingly liberated him, by liberating from his Government those useless alien provinces which used to drain his blood. If the blood of foreign soldiers is shed hereafter among the Albanian or Arabian mountains, it will be Serb, Greek, Italian, Indian, or English blood, not Turkish.

A final example-this time from the intellectual field-is offered by the history of the Modern Greek language and literature. Here, too, sudden contact with the West has sown confusion. It is to the credit of the Greeks that they have been fascinated by the Western intellect as well as by Western fashions, comforts, money-making, weapons, constitutions, and other externals. From the beginning they wanted to conceive and exchange Western thoughts in their own language and bring a new tributary to the great stream of Western literature. But what language? They broke out of the Ottoman Empire not as a Western nation with a long national history but as a commercial class and a provincial peasantry in a Middle Eastern scheme of society. The poverty of their previous social life was reflected, naturally enough, in the poverty of their vernacular. It was poor in syntax, in vocabulary, in power of expression. In the courses of centuries it might no doubt have enriched itself with the progress and experience of those 
who spoke it, but there were no centuries to spare. The language had to be Westernised like the nation. It had immediately to be converted into a vehicle for Western ideas, and it was an inevitable temptation to reconstruct it artificially out of the materials of Ancient Greek. Here was a language-the parent of the living vernacular, never obsolete as the liturgical language of the Church, a link with the mediaeval splendours of Near Eastern civilisation and with the greater ancient splendours of Hellenic. The West admired Ancient Greece as much as Modern Greece admired the West, and the ancient language, having sufficed in its day for a civilisation which enlightened Westerners regarded as the equal of their own, would surely supply now the indispensable medium for a Modern Greek variety of Western culture. Every motive for recourse to Ancient Greek existed - the wish to establish a connection with past greatness, the wish to impress the West and flatter themselves, and the urgent need for a wider range of expression. Modern Greek men of letters, moved by these important and legitimate considerations, persuaded themselves that the ancient language had never been replaced by another, and that in contaminating Modern Greek with Ancient they were really purifying their ancestral language from vulgarisms. The line that they took was inevitable, but short cuts are even more dangerous in literature than in politics, and the ancient language had two fatal defects for their purpose: it was a different language from Modern Greek and it was dead. Their amalgam of dead and living idioms has been unsatisfactory, even for official and technical prose, and poetry rebels against it. Its limitations have become so apparent that in the present generation a movement has set in for purifying the 
purified language in its turn by going back to the elements of the vernacular. But this popularising movement has its own fanaticisms and pedantries, and though it may be healthier in principle, it ignores the problem which the amalgam was intended to solve. The 'popularists' have not satisfactorily discovered how to express Western thought in Modern Greek without calling up reinforcements from the ancient language. The controversy is bitter, and is hampering not only literature but public education. Contact with the West is again the cause of the mischief, and here, too, it is difficult to see any solution.

Such examples seem to support the thesis that the shadow cast by the West, which is affecting these two contemporary civilisations profoundly in every department of life, has at present a destructive rather than a constructive influence. But the most one examines its effects the more one feels that they have hardly yet begun to work themselves out, and this is also indicated by the nearest historical parallel within our knowledge. The ancient civilisations of Egypt and Mesopotamia were in contact with Ancient Hellenic or Graeco-Roman civilisation from the early seventh century B.C., when the first Greek pirates and mercenaries landed in Cilicia and Egypt, to the late seventh century after Christ, when the last official documents in Greek were drafted in the public offices of the Arab Empire. ${ }^{1}$ Out of these thirteen centuries, the two Eastern civilisations may be said to have been overshadowed by Hellenic, as Near and Middle Eastern are overshadowed now by Western, during the ten centuries from the conquests of 
Alexander (334-323 B.C.) to the conquests of the first two Caliphs of Islam (A.D. 632-644). Compared with this millennium, the two and a half centuries of modern Western influence over the Near Eastern world, and the century and a half of its influence over the Middle Eastern world, can be seen in their true proportions. They are only the opening phase in what will be a far longer relationship, and if the ancient analogy holds good, that relationship will change its character as it continues. The contact between the Hellenic world and the two ancient Eastern societies began with the superficial conquests of commerce, war, and administration, and ended with a fusion of religious experiences. Further, while those first external conquests were made by the dominant, overshadowing Power, the religious fusion —-the most thorough and intimate kind of conquest which it is possible for one society to make over another-was substantially a victory for the worlds of Egypt and Mesopotamia. As the relationship worked itself out, it deepened in character, changed from a onesided influence into an interaction, and ended in the spiritual ascendency of the externally conquered party over the original conqueror.

Some similar ultimate reversal in the relations between the modern West and our Eastern contemporaries is not improbable, and we shall view the passing situation with greater interest and in better perspective if we bear this possibility in mind. At the same time, we must recognise that it is still beyond our horizon. Our first act-the Western conquest of the East—is still far from completion, and there is little prospect in the near future of dramatic or catastrophic reactions by

\footnotetext{
${ }^{1}$ One might even say: Until the last translations were made from classical Greek literature into
} 
the Eastern civilisations upon the West, particularly in the field of international politics and war. It would be a mistake, for instance, to take too seriously the bogeys lately dangled before us to draw us into some 'pro-Moslem' or 'antiMoslem' policy. The dangers of a entente between the Turkish Nationalist Power in Anatolia and the Bolshevik Power in Russia have been portrayed now as a reason for crushing the Nationalists, now as a reason for conciliating them. By force or by persuasion, we have been urged to deprive Russia of a formidable ally, but neither school of alarmists ever succeeded in demonstrating that this Russo-Turkish combination was going to be a permanent reality. On the face of it, it has been an entente not for action but for concerted bluff and propaganda. Even within these limits, it has evidently been viewed by both parties with misgiving. They have been forced into it because the Allied Powers have insisted on treating them both as enemies, but both have shown themselves anxious to come to terms with one or all of the Allies (even at their partner's expense), whenever they have seen an opportunity. The continuance of the special intimacy between them, after the removal of its transitory cause, is most improbable. At present Russians and Turks are more alien from each other than either are from the West, and a temporary common danger can hardly efface centuries of antipathy. A genuine rapprochement between Russia and Turkey is only conceivable on common ground produced by simultaneous Westernisation. Reaction against the West seems bound to result incidentally in mutual alienation 
on those deeper planes of consciousness which are not touched by policies of state.

Another recent bogey is the Moplah rebellion in the Madras Presidency of India, on account of which we were asked to believe a general armed rebellion in India imminent unless the British Government's policy towards Turkey were reversed. It is true that the Moplah leaders called their organisation a "Khalifat Kingdom,' but any one who has been following the Khilafat movement in India and has looked up the Moplahs' record, will not be misled by names. The Moplahs are a wild mountain population who have risen periodically against British rule ever since it has been established over them, though for the greater part of the time the British Government have been friendly to the Government of the Ottoman Caliph and have frequently given Turkey diplomatic and military support against her Christian enemy Russia. Thus the name attached to the latest Moplah rebellion is not the true explanation of its origin, and indeed the choice of this name by Indian Moslems who made a rebellion against the British Government an occasion for massacring Hindus, can only have been embarrassing to the educated Moslem leaders of the real Khilafat movement, whose policy has been based on Moslem and Hindu co-operation. The Khilafat movement among the educated classes (the only classes capable of understanding its rather abstract chains of argument) is certainly not a force to be underestimated. Underneath its academic formulas, there is a real sentiment and a real grievance, as is argued below. But the features of the Moplah rebellion indicate that the Khilafat movement will be forced to take a slow and 
peaceful rather than a violent headlong course. The effectiveness of the movement lies in the co-operation of the Hindus, and the Moplahs have demonstrated that while co-operation may not have become possible between Western-educated Hindus and Moslems when confined to Western lines of political agitation, they cannot take up the sword against the British without a danger of their followers turning their swords against each other.

Indeed, all the symptoms at present visible of reflex action by the Near and Middle Eastern worlds upon the West, point to slower and vaguer, though perhaps ultimately wider, movements than those generally prophesied in discussions of international politics. A real and a rather disquieting process is indicated by the word 'Balkanisation.' It was coined by German socialists to describe what was done to the western fringe of the Russian Empire by the Peace of Brest-Litovsk, and it has since been applied to certain general effects of the Versailles and supplementary Treaties upon Europe. It describes conveniently the growing influence in the Western world of Near Eastern peoples who are still only imperfectly assimilated to Western civililsation, and it can be traced in various spheres. It is most obvious in politics. The sovereignty of the Western Austro-Hungarian Monarchy has been superseded over large territories by that of two Near Eastern states, Jugoslavia and Rumania, and Western populations—Germans and Magyars—-have even been brought under the government of Rumans and Serbs. This settlement is in accord with our own Western principle of nationality. The greater part of the redistributed districts are inhabited by the peoples to whose national states they have now been assigned, 
and the new subject Western populations are minorities, some at least of whom were bound to be transferred with the non-Western majorities among which they live. Still, when one compares the standards of the old Austrian, or even the old Hungarian Government with those of the new governments, or the relative civilisation of the new subject minorities and the old subject majorities, one feels that the principle of nationality offers no more than a partial solution for the problems of South-Eastern Europe. Balkanisation is an unmistakable and an unsatisfactory, though it is to be hoped only a temporary, result.

The process is even more disquieting in the economic sphere, for the Western countries, just because they are more civilised and more complicated in their economic organisation, suffered more damage from the War in proportion than the non-Western belligerents. The immense expenditure of munitions on the Western front devastated the industrial districts of Belgium and Northern France far worse than Mackensen's and Franchet d'Esperey's brief campaigns of movement damaged the fields and pastures of Serbia. German industry was crippled by the blockade; Austrian (and to some extent Tchecho-Slovak) by the network of new frontiers; British by the collapse of our best continental customers. On the other hand, Jugoslavia, Rumania, and Greece have been strengthened economically by the great enlargement of their territories, and at any rate the two former by the enhanced value of Near Eastern raw materials, especially food-stuffs, compared with Western manufactures. This change has been as legitimate as the simultaneous redistribution of national wealth among 
the inhabitants of every country, but Westerners cannot regard it with satisfaction.

It is also not fanciful to discern a psychological reaction of the Near East upon the West. It has been pointed out that Western nationalism, introduced into the Near East, has promoted violence and hate. It now looks as if the Near East were infecting conflicts of nationality in Western Europe with the ferocity and fanaticism which it has imported into its own. Before the War, the ancient conflicts of interest between Ulstermen and Catholics in Ireland, or Germans and Poles in Silesia were waged with some restraint, and bloodshed was uncommon. In 1921 both these and other zones of national conflict in the West were a prey to revolutionary bands, semi-official bashy-bozuks, regular combatants whose activities were disavowed while approved by their governments, and all the other indecencies familiar in the Armenian vilayets or Macedonia. This moral Balkanisation is also unmistakable, and it is more dangerous than the political and economic manifestations of the tendency.

For good or evil, the barriers between the West and the Near East are down, and the interchange of currents seems certain to go on increasing until the waters find a common level. It is to be hoped that the Western level will not have to be permanently depressed in order to enable the Near Eastern to rise to it. But at any rate, as has been suggested above, the process will probably be spread over a long period. There is one sphere, however, in which it may produce important immediate effects, and that is in the relations between the West and the Middle East. The equally desirable adjustment between these two 
civilisations is so difficult, and is in so delicate a stage, that it is affected by imponderables. A hardly perceptible Near Eastern pressure in the Western scale at this moment might make the desirable balance between West and Middle East impossible.

This question is the special subject of this book, and is the point of permanent historical importance in the Graeco-Turkish conflict after the close of the European War, for in this connection Greece and Turkey represent respectively the Near Eastern and the Middle Eastern worlds. The other Near Eastern nations-Rumans, Serbs, and Bulgars—which have been brought by the results of the European War into closer connection with Western civilisation, have at the same time broken almost the last of their former links with Turkey. The Treaty of Sèvres, or rather the occupation of Thrace by the Greek Army, which preceded by some weeks the signing of the treaty, even removed the common frontier between Turkey and Bulgaria. The Moslem minorities in these three East European states were no danger to the ruling nationalities and are not conspicuously ill-treated. Thus no controversy remains between Rumania or Jugoslavia or Bulgaria and the Middle Eastern world, and their relations with the West have no bearing on the relations between the West and the Middle East.

It is different with Greece. On the one hand, Greece is in closer touch with the West than her Near Eastern neighbours are. She is more permeated than they are with Western education and more dependent economically than any of them on trade with Western countries. In the commercial and social capitals of Western Europe and the United States_London, Paris, Vienna, Manchester, 
Liverpool, Marseilles, Trieste, New York, Chicago, San Francisco-there are Greek colonies. Many families have lived in the West for several consecutive generations, married into Western families, naturalized as subjects of Western states, sent their children to the best schools of their adopted countries, and become Englishmen, Frenchmen, Austrians, or Americans in everything except a traditional loyalty towards their mother-country. Since there is a very widespread sentiment for Greece in the West, which has had its influence on international politics, this loyalty of the Greeks abroad has seldom conflicted with their new allegiances. On the contrary, a fortunate combination of the two has given the wealthy and the cultivated Greeks abroad (both numerous classes) opportunities of catching the ear of Western business men, Western politicians, the Western Churches, Western men of letters, and, last but not least, the Western Press.

It would have mattered less if the Greeks had only used their exceptional influence in the West against their Near Eastern neighbours like the Bulgarians, but unfortunately they are not only more closely bound up than the other Near Eastern nations with the West. Unlike them, they are still in close relations, and in very hostile relations, with the Turks, and the Osmanli Turkish nation, on its side, enjoys a special position in the Middle Eastern world.

The Middle East fins it most natural at present to express its regard for Turkey through a personal symbol. It feels loyalty to the Ottoman Sultan as Caliph of Islam, and Western scholars have rather perversely exercised their ingenuity in criticising the Sultan's claim to the title. Certainly the claim (which 
only dates from A.D. 1517) is as doubtful as the Carolingians' claim to be Roman Emperors, and even if it were proved good in law, the Osmanli Turks are as remote from the Ancient Middle Eastern world as the Austrasian Franks were from Ancient Greece and Rome. In fact, the title seems to have been regarded as an antiquarian curiosity (something like that sword and crown of Charlemagne at Vienna) by the Ottoman Dynasty till it was exploited by Abdu'l-Hamid, and the new conditions which made it worth his while to do this were chiefly due to the progress of Westernisation. The spread of Western posts, telegraphs, railways, and steamers had made it possible to keep up communications between Constantinople and the large outlying Moslem communities in India, the East Indies, China, and Russia; and the influence of Western nationalism, with its ingrained romantic archaism, had set the fashion of reviving forgotten history, even when it had little real bearing on the present. The Khilafat movement is also part of that wave of sentiment which moves Modern Greeks to think of themselves as the special heirs of Pericles or Alexander, or to overload their language with reminiscences of Thucydides and Homer. Rationally considered, it is rather a maladroit symbol for Islamic unity, since the succession of the Caliphate is the subject of the chief controversies by which Moslems have historically been divided. Technically, the Ottoman claim is rejected by the Shi'i sect (which includes all Islam in Persia and a large percentage of Moslems in Russia, Mesopotamia, and India); by the Imam of San'a in the Yemen; and by the Sherif of Morocco. Even among the more numerous Sunni or orthodox, the 
Osmanli Khilafat is not universally accepted. A puritanical aversion from the Western understanding between the Western and Middle Eastern worlds.

This is the danger in the three-cornered relationship between Western civilisation, Turkey, and Greece. Greece interposes between the other two, and some of her national ambitions cannot be realised without alienating them from each other. Such ambitions have not necessarily been more illegitimate or pursued by more undesirable means than the ordinary policies of other sovereign national states. Only, in this case, the same evils may have disproportionately grave consequences. Greece, who has gained much by the special place she holds in Western sentiment, may fairly be required to forego undue advantages on account of the special position of Turkey in the Middle East; and clearly Western statesmanship cannot afford to leave Greece and Turkey in such bad relations that each stands to gain by the other's losses.

Greece has interposed in the literal sense. In 1921, under the Allied occupation of Constantinople, an Englishman keeping an appointment with an officer at the General Headquarters of the British 'Army of the Black Sea,' or calling on an official at the Embassy, or applying for a visa at the British section of the Inter-Allied Passport Control, had to make his way through a cordon of Greek (or Armenian) door-keepers, interpreters, and clerks before he could get into touch with one of his own countrymen. Sometimes one had difficulties, and then one wondered what happened to Bulgars and Turks on similar errands, with the rival nationality holding the gates, and no other avenue to their English superiors. The employment of Near Easterners as military interpreters seemed a 
particularly hazardous policy. They were numerous, and wore the regular British uniform, with nothing to distinguish them except a green-and-white armlet. ${ }^{1}$ When off duty, it was only natural that some of them should take advantage of their khaki to pay off old scores against the former ruling race at Constantinople; and on duty, whenever they had to interpret between an Englishman and a Bulgar or Turk, they were under constant temptation to misuse their opportunities. Even if they were scrupulously honest, a tone of voice, an expression on their faces, or the mere knowledge of their nationality in the mind of the other party, might do mischief. I came across a very pertinent case when I accompanied the Red Crescent Mission to the southern coasts of the Marmara. ${ }^{1}$ The British officers successively attached to the Mission always brought with them the same Greek interpreter. He was in a painful position. The better he did his duty, the more he exposed the misdoings of-not his fellow-subjects, for he was an Ottoman Greek who had recently taken out British naturalisation papers—but his own nation, in the persons of the Greek troops and the local Greek population. His presence certainly did harm, and yet the British officers could not dispense with an interpreter, and presumably no qualified Englishman or Israelite could be found. Certainly this Karamanly Greek knew his business, and he was typical of his nation. The Greeks have taken Western education seriously. If you visit a Greek divisional or corps headquarters on active service,

\footnotetext{
${ }^{1}$ The interpreters to the French and Italian forces at Constantinople wore armlets but not uniforms. The British regulation was more generous-the foreigner in British service was treated like an English soldier-but the motive was inevitably misunderstood.
} 
you may find clerks and non-commissioned officers studying a French or an English grammar in their intervals off duty. Efficient Greek interpreters are abundant, Turkish or English interpreters rare or unknown. The preponderance of Greek and Armenian interpreters in the British Army of Occupation at Constantinople was a result of the ordinary economic laws of supply and demand. But it did create a real barrier between the British Army and members of the other local nationalities, and both Greeks and Turks regarded it as an indication of British policy. They were wrong, but the misconception has done considerable political damage.

Greece had also interposed geographically by her acquisition of Eastern Thrace under the Treaty of Sèvres. From the Black Sea to the Marmara and the Aegean, an unbroken belt of Greek territory separated Turkey in 1921 from every other state in Europe. You could not telegraph from Constantinople or Smyrna to London or Paris without running the gauntlet of the Greek censorship, for the marine cable passes through a transmitting-station on the Greek island of Syra, and the overland wire from Constantinople crosses Eastern Thrace. In the spring and summer of 1921 , at any rate, the Greek military censorship was stringently exercised over both Press and business messages in transit. In this the Greek Government were only exercising their legal sovereign rights, but it is as much against the general interest that Greece should be invested with the right to control private communications between Turkey and the West as it is that Turkey should control the passage of merchant shipping through the waterway between

\footnotetext{
${ }^{1}$ See itinerary in Preface.
} 
the Mediterranean and Russia. It is no answer to say that this as an exceptional war-measure, for Greece and Turkey might often be at war for years together, and in peace-time the possibilities of surreptitious censorship might be even more objectionable. Presumably more expensive and circuitous telegraphic routes could be organised (for instance, through Varna and Constanza), but this would still leave Greece astride the Oriental Railway between Constantinople and Sofia - the only possible route for quick travelling between Turkey and Western Europe.

But the most serious disturbance in the relations of West and Middle East has been produced by the Greek occupation of Western Anatolia. The mischief has been out of all proportion to the extent of the territory. The area provisionally assigned to Greece round Smyrna under the Treaty of Sèvres was small compared to the territories mandated to Great Britain and France in Syria, Palestine, and Mesopotamia. The whole area carved out of the Ottoman Empire since 1821 to make an independent Greece is even smaller in comparison with the vast French and British dominions over Middle Eastern peoples in India, the Nile Basin, and North-West Africa. It is the misfortune as well as the fault of Greece—and the unmitigated fault of Allied statesmanship—that the occupation of Smyrna has had specially untoward consequences, but the circumstances could not fail to make trouble. The Greek troops were sent to Smyrna, with a mandate from the Supreme Council and under cover of the guns of Allied warships, more than six months after the armistice with Turkey. The landingtechnically camouflaged as a movement of Allied troops for the maintenance of 
order-was probably contrary to the letter of the armistice, for no previous local disorder had been proved, and it was certainly contrary to its spirit. Within a few hours of the landing, the troops committed a bad massacre in the city; within a few days they advanced into the interior; and a new and devastating war of aggression against Turkey began in her only unravaged provinces. In the sixteenth month of this war, the Powers gave Greece a five-years' administrative mandate in the Smyrna Zone, with the possibility of subsequent annexation. Turkey was the leading state of the Middle Eastern world, Greece a Near Eastern state of recent origin. She had been admitted with generous facility into the Western concert of nations; but the mandate now given to her-to govern a mixed population in which one element was of her own nationality—would have been a difficult test, in parallel circumstances, for the most experienced Western Power. It was wanton rashness to make such an experiment at Turkey's expense; and after the experiment had proved a failure, it showed blind prejudice and partiality on the part of Western Governments that they should continue to give Greece material and moral support in her enterprise as an apostle of their civilisation.

This policy would in any case have made bad feeling between the Western and the Middle Eastern worlds, for we had reached a phase in our relationship in which Middle Eastern peoples were—rightly or wrongly—ceasing to tolerate the domination even of the leading Western Powers, in countries which they have governed, on the whole beneficially, for many years. This movement of revolt, which might have been gradual, has been formidably 
accelerated by the consequences of the European War, and our relations have now entered on a phase which is admittedly critical. In these circumstances, the statesmanship responsible after the armistice for the Graeco-Turkish conflict is unpardonable. It introduced a cruel and unnecessary irritant into a dangerous wound, at the risk of making it incurable. It is not as if our misunderstanding with the Middle East had been past mending. It was not, and it may still not be, if the irritant can be removed without leaving malignant after-effects. Conflicts between civilisations are terrible, because civilisations are the most real and fundamental forms of human society. But just because they are ultimate forces, their differential does not consist in externals like colour or physique or birthplace or mother-tongue, but in states of mind; and while the Ethiopian cannot change his skin or the foreigner his accent, and it is difficult for the subject of an efficient government even to forge a birth-certificate, men's minds can be turned, even at the eleventh hour, from the paths of destruction. Civilisations are differentiations of consciousness, and happily there are possibilities of extensive mental adjustments between the members of one civilisation and those of another. The absorption of the Near Eastern into the Western outlook, and the discovery of a modus vivendi between the outlooks of West and Middle East, are not desperate, though they are difficult problems. But at any moment they can be made desperate by errors of judgment on the part of a few men in power. 


\section{WESTERN DIPLOMACY}

ON the $18^{\text {th }}$ March 1912 I was walking through an out-of-the-way district in the east of Krete. The landscape was the bare limestone mountain-side characteristic of the Aegean. Villages were rare, and some of them had been sacked during the civil war of 1897 and not reoccupied. Suddenly, as the path turned the corner round a hillside in the limestone wilderness, a Western countryhouse came into view. It was built in the Jacobean style; the curves and flourishes of its façade were in excellent preservation; one's own friends, or their great-grandparents, might have walked out of the front door. But, after a few steps towards it, the illusion of life faded. The door was half walled-up with loose stones to convert the ground-floor into a sheepfold, the windows stared blindly, the cornice had no roof above it. It was the villa of some Venetian 
landowner or official, and must have been deserted since the great War of Candia, two and a half centuries ago. ${ }^{1}$

The empires founded by mediaeval Western states in Near and Middle Eastern countries are a memento mori for the modern Western Empires which are such an imposing and characteristic feature in the landscape of the contemporary world. That Venetian colony in Krete lasted four and a half centuries, a longer life than any British colony can yet boast of. In Galata, where French, English, and American firms now have their offices, there was once a Genoese settlement, extra-territorial and self-governing in the manner of modern Shanghai. When this Western community had diplomatic difficulties with the Imperial East Roman Government, it used to shoot large stones across the Golden Horn into Constantinople from its municipal catapults. It lived two centuries (A.D. 1261-1453), and planted daughter-colonies in the Crimea and on the Don, which opened up an overland trade with Russia, India, and China. Modern Russia has only been the principal Black Sea Power for the last 148 years. Genoa held that position for about fifty years longer. The Genoese Chartered Company which governed the Aegean island of Khios had as romantic a career as John Company in India. The Florentine bankers who became Dukes of Athens anticipated the exploits of Rajah Brooke and Cecil Rhodes; and the transformations of the Order of St. John in Palestine, Rhodes, and Malta suggest strange possibilities of evolution for the more recently founded Jesuit and

\footnotetext{
${ }^{1}$ A.D. $1644-69$.
} 
Evangelical Missions. About the 1400, the Near East seemed on the verge of becoming an annex to the constellation of miniature Western Great Powers in Northern Italy, and then, within a century or two, this exotic growth of commerce, war, administration, and diplomacy was swept away.

When we look at our present ascendancies in the East through this glass, they too appear unsubstantial, and it becomes possible to imagine that Western manufacturers, garrisons, governors, protectorates, diplomatic understandings and rivalries may be eliminated from the non-Western civilised countries of the modern world before the mental influence of the West upon other civilisations has reached its maximum, and long before their counter-influence upon the West has properly begun. However, the external and material ascendency of the West is one of the realities of the moment, and the most interesting chapter in a story is often the last. In the Graeco-Turkish borderland of the Near and the Middle East, the diplomatic aspect of this ascendency is in the foreground.

During the battle of the In Önü in March $1921,{ }^{1}$ a Greek private soldier said to me: 'This is really a battle between England and France for the possession of Anatolia.' He meant it, I think, in the literal sense, for a majority of the Greek and Turkish combatants in this battle believed that French and British officers were directing operations on opposite sides. ${ }^{1}$ Their misapprehension showed the crudeness of their views about Western diplomatic methods. Western governments which are supposed to be allies are too experienced, and

\footnotetext{
${ }^{1}$ See Chapter VI.
} 
almost too respectable, to act openly against each other. They know that scandal is never worth while; and yet in essence this Greek soldier's remark was true. The distant Western Powers were the protagonists in the war-after-the-war which has devastated considerable tracts of the Near and Middle East, while the local peoples, who were acting and suffering, were pawns. If Mr. Thomas Hardy were to write a drama called 'The Patriots,' he would no doubt present Professor Masaryk, Mr. Venizelos, Mr. Stambolisky, General Pilsudsky, the Emir Feisal, and Mustafa Kemal Pasha as men walking in a dream, like his Pitt and Napoleon; and when the scene dissolved into a vision of the real agent, we should see the grey outlines of rooms and corridors in Downing Street and on the Quai d'Orsay. Perhaps the chorus of spirits would be composed of impotent Western observers like myself.

There is nothing new or paradoxical in this view of the relations between Near and Middle Eastern states and Western Powers. Change the metaphor from chess to sport, and it is a commonplace. The correspondent of the Times at Constantinople subscribed to it on the $5^{\text {th }}$ October $1921,{ }^{2}$ when he reported a rumour that certain circles in the Quai d'Orsay were advising in the Turkish Nationalist Government at Angora to adopt an attitude of reserve towards any suggestions of negotiation until Greece found herself in greater difficulties. 'The policy,' he telegraphed, 'of backing the protagonists (sic) in the present Eastern War as if they were race-horses, is a policy of which each of the Entente Powers in turn has been guilty, and must be abandoned if peace is ever to be restored in

\footnotetext{
${ }^{1}$ See 'The Origin of a Legend,' pp. 254 seqq.
} 
the Levant.' The metaphor was not of his invention. It was an allusion to Lord Salisbury's famous recantation of the policy which he had pursued at the Berlin Conference of 1878: 'We have backed the wrong horse!' The phrase sums of the spirit of which Western Powers have betted and quarrelled in the Near and Middle Eastern arena for the last 250 years, ever since they had the ships, men, and money to fight there if they wanted to. It has been wrong-headed and disastrous behavior. The mere description of it is an indictment, but it is an exposure of the little wisdom in the government of human affairs rather than of any special depravity in Western civilisation.

The exploitation of small states by greater is particularly mischievous when the two groups of states belong to different civilisations, but this difference is not the cause of it. It occurs whenever such small states are hostile to one another and weak and the larger states hostile to one another and strong. A group of small, mutually hostile, and therefore un-self-sufficient states creates automatically a sort of international vacuum, into which the powerful states around are attracted. Their centripetal movement is one form of 'imperialism,' and when several converging imperialisms collide in the vacuum, there may be a general disaster. What has been happening latterly in the Near and Middle East had been going on for four centuries (from about 1470 to 1871) in the bosom of Western Europe. Little rival German and Italian states were backed by the big rivals_Spain, France, England, Austria, Prussia, Sweden, Russia. The dynamic consequences were perpetual diplomatic conflicts and wars, which recurred until

\footnotetext{
${ }^{2}$ See his telegram in the Times of the $10^{\text {th }}$ October 1921.
} 
the national unification of Germany and Italy changed this particular vacuum into a plenum and made a local equilibrium possible. It was after this that the thrust of forces, balanced at last further west, directed itself eastwards into another vacuum and dangerously accentuated the stresses of the 'Eastern Question.'

Such vacua are always a source of danger, and though the Italian and German vacua in Western Europe were removed before they had produced fatal consequences, the sort of catastrophe which they might have brought, and the Eastern vacuum still may bring about, is illustrated by the history of GraecoRoman civilisation in the third and second centuries B.C. The ambitions, fears, and rivalries of the small states round the Mediterranean-Messana, Syracuse, and Saguntum; Aetolia, Pergamon, and Rhodes—involved their powerful neighbours in wars which did not come to an end till one Great Power, Rome, had eaten up four others-Carthage, Macedonia, Syria, and Egypt. The sequel was universal impoverishment and revolution, and the victorious Power also came to an unpleasant end, like a snake in the Zoological Gardens some years ago which, in a tug-of-war with another snake over the same pigeon, swallowed its rival as well as the bird, and died by inches as the foreign body stiffened in its throat.

Only the Great Powers themselves can save each other from such fatalities, as well as from the constant friction and waste of energy into which the presence of vacua more commonly leads them. The first safeguard against the danger is moderation on their part, but the small states cannot be acquitted of responsibility. So long as they are willing to sell their services to some Great 
Power in order to procure that Power's backing against the own small rivals, they deserve to be treated as pawns and no sentiment need be wasted upon them. A remedy for their situation is in their peoples' hands. They can change the vacuum into a plenum by co-operation. When the Italian and German peoples made up their minds to combine into national states, ${ }^{1}$ the traditional displomacy of the Powers was unable to stop them, and from that time onwards Italy and Germany ceased to be arenas of international conflict. Instead, they took their places as Great Powers in the new arena of the Near and Middle East, and began to use the small states here as they had been used themselves. This arena is unhappily still open, but the Eastern peoples can close it by refusing, in their turn, to be pitted against one another. As it is, they are willing victims, and the Powers are in some degree victims as well as villains. In such situations, international politics move in a vicious circle, and the goodwill of all the parties is needed in order to break it.

Having stated the case for the defence of the Powers' diplomacy in the East, I can now proceed with the indictment. In the terms suggested above, the first phase after the European War may be described somewhat as follows. France was backing Poland vigorously, and Hungary tentatively, against Germany and Russia; and she was backing Turkey tentatively against Russia and vigorously against Greece because Greece had been backed by Great Britain. Great Britain was backing Greece against Turkey, because an

\footnotetext{
${ }^{1}$ Between 1848 and 1871.
} 
aggrandised Greece dependent on British support would save Great Britain the trouble of herself imposing her Eastern peace-terms. Italy was backing Turkey against Greece as payment on account for prospective economic concessions in Anatolia; and Russia was backing Turkey against Greece to deter her from purchasing the backing of any of the Western Powers who were Russia's enemies. Russia also backed the Armenian Republic of Erivan to a limited extent against both Turkey and Azerbaijan, as a barrier between possible Turkish 'Pan-Turanian' ambitions and the oil-fields of Baku; and she backed both Erivan and Azerbaijan against Georgia in order to complete the restoration of her authority over her previous possessions in Transcaucasia. In this criss-cross of exploitations Russia's part was perhaps the least blameworthy, because she had the best claim to be acting in self-defence.

As for the pawns, the three Transcaucasian states threw away their brief independence by refusing to settle their boundary disputes and work together. Hungary would sell herself to anybody who would help her to recover her frontiers of 1914, and Poland would almost do the same for the frontiers of 1772. Greece had sacrificed her exchange and her young men's lives for a gambler's chance of realising her utmost national ambitions. Turkey, who was genuinely fighting for her life, deserved the same cautious sympathy as Russia.

Only four small states in the area had begun to shake themselves free from the vicious circle of clientage and exploitation. There were TchechoSlovakia, Jugoslavia, Rumania, and Bulgaria. The 'Little Entente' between the first three ought not to be condemned because its primary motive has been 
mutual insurance against the largely justifiable restlessness of Hungary under the Treaty of Trianon. Short of an uppeasement of the feuds between the small states, it is a gain that they should pursue these feuds among themselves without drawing in the Great Powers as rival backers; and, besides, arrangements originally made for one purpose may often be found serviceable for others. Dr. Benes probably had economic co-operation in his mind from the beginning. This economic motive might attract Austria into the group, and might even bring about the ultimate adhesion of Hungary. One thing is certain: the treatment of minorities everywhere_-including unnecessarily and unjustly subjected minorities-will improve in proportion to the growth of mutual confidence between the state of which they are subjects and the other state of which they would prefer to be citizens.

Bulgaria, defeated and denied her national unity but not embittered, was showing even more remarkable wisdom. Mr. Stambolisky's policy has apparently been to let territorial claims lie, to bring about a reconciliation in feeling as well as in form with Jugoslavia and Rumania, and to build up a 'Green International' of the peasant-proprietors of South-Eastern and Central Europe, who find themselves in a precarious position between the urban capitalism of the Western Powers and the urban communism of Petrograd and Moscow. His movement is complementary to Dr. Benes's, and the two seem bound to converge. The Poles, Tchechs, Slovenes, and Croats, who have common economic interests and no national quarrel with the Bulgars, are the natural intermediaries between Bulgaria and the Rumans and Serbs. 
These are promising materials for the establishment of a plenum in the Near East, and there are Near Eastern statesmen who realise its desirability. For example, Mr. Take Jonescu, the leading advocate of the Little Entente in Rumania, was careful to declare (in a statement published in the Times of the $11^{\text {th }}$ October 1921, after a visit to London): 'I am not following any "French" policy against Britain or any "British" policy against France.' It would have been difficult for Greek and Turkish statesmen at that date to make any similar declaration, though if they are wise, they will take the first opportunity to enable one another to dispense with French, British, or any other backing. Until they succeed, they will both be broken more and more cruelly upon the wheel of a greater rivalry than theirs.

In modern times, since the effacement of the miniature Powers of Northern Italy, there have been three main Western rivalries in the Near and Middle East: between Great Britain and France, between Great Britain and Russia, and between Great Britain, France, and Russia together and Germany. The first is the most important of the three. It is the oldest; it lived on underground after the Entente of 1904 and even during the European War; and since the armistice it has again overtopped the other two.

This Anglo-French rivalry in the Near and Middle East can be traced back to the sixteenth century. It was a commercial rivalry so long as the vacuum which attracted it was only economic and not political. In the eighteenth century, after the break-down of the Mogul Empire, it blossomed out in India into a military struggle for direct dominion, which terminated in the complete defeat of France. 
This was its classic period, but Napoleon's efforts to recover a footing in India by a new route transferred the centre of stress to Egypt and the Ottoman Empire and developed an intermediate form of competition, conditioned by the semirecovery of Turkey from her eighteenth-century decline, and the semi-selfsufficiency of the Near Eastern nations which have been disentangling themselves from her. Since the Congress of Vienna in 1814, France and Great Britain have never fought in the Levant with naval and military weapons (though they have several times been on the verge of open war), but their struggle has been real and sometimes bitter for all that, and though it has not here gone the length of empire-building, it has not been confined to trade. Its characteristic fields have been diplomacy and culture, its entrenchments embassies, consulates, religious missions, and schools. It has flared up on the Upper Nile, in Egypt, on the Isthmus of Suez, in Palestine, in the Lebanon, at Mosul, at the Dardanelles, at Salonika, in Constantinople. The crises of 1839-41 and 1882 over Egypt and of 1898 over the Egyptian Sudan are landmarks on a road that has never been smooth, for conflicts between Sultan Mahmud and Mehmed Ali, Maronites and Druses, Greeks and Turks, Syrians and Hijazis, Arabs and Jews, have perpetually kept alive the combative instinct in French and English missionaries, schoolmasters, consuls, diplomatists, civil servants, ministers of state, and journalists. One cannot understand—or make allowances for-the post-war relations of the French and British Governments over the 'Eastern Question' unless one realises this tradition of rivalry and its accumulated inheritance of suspicion and resentment. It is a bad mental background for the 
individuals who have to represent the two countries. The French are perhaps more affected by it than we, because on the whole they have had the worst of the struggle in the Levant as well as in India, and failure cuts deeper memories than success.

The other two rivalries less immediately concern my subject. The AngloRussian rivalry has been diplomatic and military, with the main stresses in Afghanistan, in Persia, and at the Black Sea Straits. It was prominent from about 1815 until 1917, suffered a sudden eclipse with the collapse of the Russian Power, and is at present a secondary though far from a negligible factor in the Middle Eastern situation. it will reassert itself as Russia recovers, unless the vacuum continues to be occupied by the Anglo-French rivalry, or the formation of a local plenum happily eliminates this arena of rivalry altogether.

The Entente between France, Great Britain, and Russia against Germany has been the shortest and strangest grouping of all. It was only in existence from the Anglo-Russian Agreement in 1907 to the Bolshevik revolution in Russia at the close of 1917 . it never had the solidity of the older Franco-Russian combination against Germany in Europe, and it is unlikely to recur. It lacked the comparatively strong cement of fear, except in so far as it was a corollary to the rapprochement of the same three parties over European politics. Its direct motive was covetousness, and it rested locally on nothing more substantial than the precarious honour among thieves who find their business threatened by a vigorous and talented competitor. Some of the thieves, at any rate, never got out of the habit of picking their temporary partner's pockets. 
The venerable Anglo-French rivalry in the Near and Middle East was not brought to an end by the Entente of 1904, whatever results that agreement may have had in the North-American Fisheries or in Tropical Africa. ${ }^{1}$ This rivalry was more or less dormant during the few years before the War, when the partition of Asiatic Turkey and the alteration of the status of the Straits did not appear imminent. Each Power's attention at that time was mainly taken up by the common rivalry with Germany, and both Powers—-to their credit—-tried to come to agreements with Germany over their respective Eastern interests before the War began. But Turkey's intervention in the War removed all restraint on Western appetites. Germany dreamed of swallowing Turkey gradually but whole, the Allied Powers of dividing her piecemeal. But how was she to be carved up? Their abandonment of any thought of compromise with Germany in the East made it extremely difficult for them to compromise with one another. Their conflicting ambitions, dragging on the leash, pulled them asunder, in spite of their acute common danger; and by the middle of 1915 the tension had become so serious that the problem had to be faced and some immediate definite agreement attempted. The deciding factors were the military breakdown of Russia in the course of 1915 and the overtures made to the British Government in the summer of that year by the Sherif (now King) Husein of Mecca, on behalf of a secret Arab Nationalist Committee at Damascus.

\footnotetext{
${ }^{1}$ Egypt and Morocco came within the purview of the understanding, but not Turkey or Greece.
} 
To prevent the Russian Government from making a separate peace, the French and British Governments acquiesced in the acquisition by Russia of Constantinople and adjoining territories commanding the Black Sea Straits. An agreement was signed, in which these territories were defined. They included the Gallipoli Peninsula and a strip along the European coast of the Marmara joining it to the Peninsula of Constantinople-the whole roughly corresponding to the European section of the 'Zone of the Straits' as laid down in Article 179 of the Treaty of Sèvres and indicated on the map annexed to it. On the Asiatic side, most of the Ismid Peninsula was included, but not the Bigha Peninsula nor the Asiatic parts of the Sèvres Zone between Bigha and Ismid. France and Great Britain did not bind themselves to carry on the war till these terms were enforced on Turkey and her allies, but merely consented to them in advance, in the event of their proving enforceable when peace was concluded. In 1917, however, any claim to annexations was twice ${ }^{1}$ formally and publicly renounced by Russia, and no Russian Government is likely to revive this particular claim, unless either Turkey or the Western Powers establish some régime in the Straits which does not secure a permanent commercial right-of-way for the riverain Powers of the Black Sea.

King Husein's overtures in the summer of 1915 led to long negotiations between him, as spokesman of the Arab National Movement in the Ottoman Empire, and the British Government acting for the Allies, and subsequently to the

\footnotetext{
${ }^{1}$ On the $10^{\text {th }}$ April and the $19^{\text {th }}$ May, both occasions being before the accession of the Bolsheviks
} 
revolt of the Hijaz against Turkey on the $9^{\text {th }}$ June 1916. But they also forced Great Britain, France, and Russia to agree upon a definition of their own respective claims in Turkey-in-Asia. The resulting secret agreement between the three Powers about the disposal of Asiatic Turkey, unofficially and also unjustly known as the 'Sykes-Picot' Agreement, ${ }^{2}$ was signed in May 1916, and its terms were afterwards published by the Bolsheviks when the Petrograd archives fell into their hands.

The parts of this agreement relating to the Arab provinces do not directly concern the Graeco-Turkish conflict. It is sufficient to say that while the letter of these parts could be so interpreted as not to contradict the commitments to King Husein into which we were entering simultaneously, the two sets of arrangements were incompatible in spirit. King Husein supposed that he was securing from the Allies a general undertaking, with certain reservations, to promote and uphold the independence of the Arabs. Meanwhile, the Allies were really arranging among themselves that Great Britain and France between them should exercise varying degrees of political authority over all Arab territories in Asia except the Hijaz itself. It is true that the more attenuated degrees of this ascendency were styled 'Arab independence,' but that technical use of the word

\footnotetext{
to power.

${ }^{2}$ The final text of the agreement was drafted by Sir Mark Sykes and M. Georges Picot on behalf of the British and French Governments respectively, but these two gentlemen only settled details and phraseology. The fundamental points in the agreement had already been worked out in conferences of leading statesmen and officials on both sides, before it was handed over to them for completion. The unofficial name, used for brevity, gives a wrong impression of the part they played, and now that the agreement is discredited and Sir Mark Sykes unable to defend himself, owing to his lamentable death from influenza during the Peace Conference at Paris, it is important that no injustice should be done to his memory. The responsibility on the British side for this agreement lies with the British Government.
} 
'independence'-a novelty even in diplomacy—would no doubt have been misunderstood by the Arabs, and so the text of the Three Power Agreement of 1916 was prudently not communicated to the Hijaz Government. When King Husein subsequently got hold of the Bolsheviks' version, there was a diplomatic storm; and when, after the armistice, the inevitable collision occurred between the Allies' arrangements with the Arabs and their arrangements among themselves, King Husein practically broke off diplomatic relations. No plenipotentiary of the Hijaz Government signed the Treaty of Sèvres.

In the non-Arab territories of the Ottoman Empire, the Allied Governments were not embarrassed at the time by any commitments to the people of the country. The Turks were at war with them; offers previously made to Greece at Turkey's expense had been declined and withdrawn; the Armenians had got themselves massacred by the Turks for helping the Allies without getting the Allies committed in return to doing anything for them. In these territories, therefore, the partition was defined in more downright terms. There were to be no 'independent' spheres of influence here, and each Power recognised the other's right to dispose in whatever way it chose of the zone assigned to it. In this way France was given the absolute disposal of a vast zone including Cilicia, East-Central Anatolia, and Western Kurdistan, the boundaries being identical with those of the 'area in which the special interests of France are recognised' in the Tripartite Treaty of the $10^{\text {th }}$ August 1920 , as defined in Article 5 and set out 
on the published map. Russia received a somewhat smaller territory ${ }^{1}$ bounded by the French Zone, the town of Trebizond, and the pre-war Russo-Turkish frontier. It is worth noting that this area, which Russia, if she chose, was to annex outright, was practically identical with the area which President Wilson, arbitrating in pursuance of Article 89 of the Treaty of Sèvres, has since awarded to an independent Armenia. Russia's intentions in regard to it may be judged, not only from the general record of the Tsardom towards subject nationalities, but from the fact that during the period in 1916 and 1917 when this territory was temporarily under Russian military occupation, General Yudenich began to plant Cossack colonies on lands belonging to local Ottoman Armenians who had previously been deported and massacred by the Turks on account of their supposed sympathy with the Allies. The colonies were meant to be permanent, and natives of Transcaucasia (i.e., practically all Russian Armenians) were declared ineligible! The intention was clear, and the terms of the agreement debarred our Government from protesting against it. Yet at the very time when the agreement was being made, I was being employed by His Majesty's Government to compile all available documents on the recent treatment of the Armenians by the Turkish Government in a 'Blue Book,' ${ }^{2}$ which was duly published and distributed as war-propaganda! The French Government made use of the Armenians in a different way. They promised to erect an autonomous

\footnotetext{
${ }^{1}$ Russia's principal Eastern gains under the secret agreements were (1) Constantinople and the Straits, and (2) the right, apparently conceded by Great Britain, to do as she pleased with the 'Russian Zone' in Persia established by the bipartite agreement of 1907.
} 
Armenian state, under their aegis, in the Cilician part of the Anatolian Zone, and the promise brought them several thousand Armenian volunteers, most of whom were enrolled in the Légion d'Orient and served for the rest of the War. That is perhaps the only asset which France has ever realised from this zone, which looked so substantial an acquisition in the emphatic terminology and highlycoloured sketch-maps of the agreement. What the Armenians have got out of the French Government's promise can only be realised adequately by a study of events in Cilicia since the armistice!

One other point in the 1916 agreement has to be noted. The British Government-which had annexed Cyprus to the British Empire after declaring war on Turkey, had offered it to Greece in 1915, and subsequently had withdrawn the offer-now undertook not to alienate the island without the consent of France. As four-fifths of the Cypriots are Greeks and the other fifth Turks, this pledge has a bearing on the relations of these two nationalities.

The agreement of 1916 was not communicated to the Italian Government any more than to King Husein, but Western Governments are efficient, and the Italian Secret Service discovered its existence. ${ }^{1}$ Under the Treaty of London, in virtue of which Italy had come into the War, the three other Powers had promised Italy_among other things_-an 'equitable' zone in the region of Adalia (in SouthWestern Anatolia) in the event of their making territorial acquisitions in Turkey themselves. Accordingly a new, long, and ludicrous series of negotiations began. The word 'equitable' in itself was an inexhaustible mine of dialectic. How

\footnotetext{
${ }^{2}$ Miscellaneous No. 31 (1916).
} 
was it to be translated into square kilometers? And had it not a moral implication? An assessment of moral damages suffered by being kept in the dark must have swelled the Italian Government's territorial claim, and the immense extent of the Turkish territories eventually assigned to Italy in the secret agreement made by the British, French, and Italian Prime Ministers in April 1917 at St. Jean de Maurienne, indicates that two of these gentlemen had a bad conscience. This Italian Zone consisted of a substantial section which Italy might dispose of as she chose, and a much more modest section north of it in which she was to have the monopoly of giving advice and assistance to an 'independent' native Government. The annexable zone included both Smyrna and Konia, and the total area (the two parts would hardly in practice have been distinguishable) can be most easily described by reference to the 'area in which the special interests of Italy are recognised' in the Tripartite Treaty of the $10^{\text {th }}$ August 1920. It differed from the latter area in excluding its north-western corner, while including practically the whole of the 'territory of Smyrna' afterwards provisionally assigned to Greece under the Treaty of Sèvres. A portentous commitment—but there was a way out, for the instrument contained a legal flaw. Here, however, I shall follow the example of Herodotus, when he touches upon mysteries, and 'though I know, prefer to hold my tongue.' This particular mystery is indeed common knowledge among those interested—not least among Italians. At the same time, I cannot discover that it has been made public in the technical sense, either by the Allied Governments or by their enemies, and

\footnotetext{
${ }^{1}$ I had this information recently from an excellent Italian source.
} 
certainly my own knowledge of it was originally obtained through official channels. An even more pertinent reason for passing it over is the undesirability of reviving old grievances at a time when co-operation and goodwill between the Western Powers in the East are of particular importance. . . .

So the validity of the St. Jean de Maurienne agreement remained debatable, but the controversy has become academic. One need only turn to the public 'Tripartite Agreement between the British Empire, France, and Italy respecting Anatolia, signed at Sèvres, $10^{\text {th }}$ August 1920.'1 Here the French and Italian Zones (with the modifications in the Italian Zone above mentioned) reappear, but their bold colours and solid outlines have faded into something rather blank and thin. They have become merely 'areas in which the special interests of France and Italy are respectively recognised' by them and by Great Britain. The treaty only binds the three Powers; Turkey is not a party to it; the 'special interests' are defined in Article 1 as a 'preferential claim. . . to supply assistance ... in the event of the Turkish Government or the Government of Kurdistan being desirous of obtaining assistance in the local administration or police.' The only unconditional advantage now attaching to the zones is that 'the Contracting Parties undertake not to apply, nor to make or support applications on behalf of their nationals, for industrial or commercial concessions in an area in which the special interests of one of the said Powers are recognised, except in cases where such Power declines or is unable to take advantage of its special 
position.' ${ }^{1}$ Moreover, an unconditional obligation to 'accept therewith the responsibility for supervising the execution of the Treaty of Peace with Turkey with regard to the protection of minorities' is undertaken ${ }^{2}$ by each Power in the area within which its special interests are recognised.

The advantages respectively appropriated by the three Powers in this treaty are so remarkably small compared with those envisaged in the agreements of 1916 and 1917, that one seeks a reason. Did it lie in the necessity in this case for publicity, and if so, did the public document simply mean to the initiated what its secret predecessors said outright? This explanation is supported by the precedent of the Anglo-Russian Agreement of 1907 concerning Persia—a public bipartite agreement between two Powers, who mutually proclaimed zones of respective 'disinterestedness' in Persia in each other's favour. Persia was not a party, and the analogy of form with the present Tripartite Treaty concerning Turkey is very close. On the other hand, the AngloRussian Agreement in practice rapidly approached results analogous to those avowedly contemplated in Turkey according to the two secret agreements. ${ }^{1}$ Did the authors of the Tripartite Treaty of 1920 calculate that in Turkey, too, the same transformation could be effected without too much scandal in the course of time? This explanation is plausible but cannot easily be reconciled with the subsequent

\footnotetext{
${ }^{1}$ Treaty Series No. 12 (1920), not to be confused with the Treaty signed at Sèvres on the same date by all the Allies (except Jugoslavia and the Hijaz) and Turkey.

${ }^{1}$ Article 2.

${ }^{2}$ Article 9.

${ }^{1}$ The transformation of the other party's zone of disinterestedness into one's own zone of interest (in the most unfettered sense) would undoubtedly have been completed in Persia at the end of the War, if the process had not been cut short by the Russian Revolution. The Russian
} 
policy at any rate of the French Government. On the $20^{\text {th }}$ October 1921, M. Franklin-Bouillon, acting for his Government, made an agreement with Yusuf Kemal Bey, acting on behalf of the Turkish National Government of Angora, and in this agreement the French Zone was tacitly abandoned. The claim to special interests was passed over without a word; the rights of minorities were confirmed not by France nor even jointly by both contracting parties, but by the Great National Assembly of Turkey; and the sole economic concession secured to a French group was the exploitation of the Bozanty-Nisibin section of the Baghdad Railway. ${ }^{2}$ When they ratified this agreement with Angora, the French Government can hardly have contemplated putting aggressive interpretations on the Tripartite Agreement thereafter.

Before searching further for the cause of these far-reaching abatements of claims, it will be well to compare with the original claims of the Powers the assets actually held by them in Turkey in the autumn of 1921.

The Russian claim to Constantinople and the Straits had disappeared. The Constantinople and Ismid Peninsulas remained under Ottoman administration, but three Allied High Commissioners were in control and there was a mixed British, French, and Italian garrison. There were also Allied troops on Gallipoli and at Chanak Kalé, and the Straits were commanded by the Allied navies.

Government intended this transformation from the outset. The British did not, but had to follow the Russian lead.

${ }^{2}$ In his personal letter of the $20^{\text {th }}$ October 1921 to Mr. Franklin-Bouillon, Yusuf Kemal Bey also offered the concession of one group of mines (with 50 per cent. Turkish population) and promised benevolent consideration of future French applications. 
The Powers had recognised the nominal independence of all the Arab territories of the Ottoman Empire in Asia, even of those which they had left at one another's absolute disposal under the secret agreement of 1916; and the 'control,' contemplated in the 1916 agreement, over 'independent' Arab territories had been conferred by a mandate from the League of Nations. In 'independent' Palestine, and half-dozen 'independent' states which France, as mandatory, had set up in Syria, the British and French Governments respectively were wielding all the powers of sovereignty. In Syria the French mandate had actually been established by military operations. The Arab National Government formed at Damascus after the Turkish evacuation had been overthrown by force in July 1920 and a war indemnity had been imposed.

In Mesopotamia, which was conquered by the British Army from the Turks during the War, British troops had remained in occupation, and many small risings of the Arab population, and one big rising in the summer of 1920, had been put down. But the mandatory Power had since set up a single Arab government for the whole country and was rapidly reducing its garrisons. It looked as if the Mesopotamian Arabs would become genuinely independent before long, and if this happened, the independence of Syria was likely to follow. The Syrians being more ripe for self-government than the Mesopotamians, the liquidation of British control in Mesopotamia seemed bound to hasten that of French control in Syria. Thus, even in the Arab area, the claims staked out in the secret agreements were far from having been realised, and a still further 
diminution of the authority exercised there by the British and the French Governments was probable in the near future.

But the difference between claim and actuality was far more striking in Anatolia. Here three immense zones, swallowing up two-thirds of the whole country and placed at the absolute disposal of Italy, France, and Russia respectively, had simply disappeared from the map. The Soviet Russian Government had not only renounced the Russian claim but had even ceded to Turkey (under a treaty signed at Moscow with the plenipotentiaries of Angora ${ }^{1}$ ) territories possessed by Russia in 1914. France had renounced her claim, in the Franklin-Bouillon Agreement of the $20^{\text {th }}$ October 1921; and she had incidentally made a vicarious sacrifice on behalf of Italy, for Italy could no more avoid following the French lead in regard to Anatolian Zones than France the British in regard to mandates over Arabs. The paper structure of Western dominion had collapsed, and the site was occupied by a national Turkish Government. This Government had laid solid foundations; it disposed of a formidable army; and its independence was a reality, not a fiction of an experiment like that of the new Arab Governments at Beirut, Damascus, Aleppo, and Baghdad.

But the picture has still to be completed, for in the autumn of 1921 one Power held not only everything accorded to her by treaty but a great deal more,

\footnotetext{
${ }^{1}$ The terms of this Treaty of Moscow between Angora and Russia had been anticipated in the Treaty of Alexandropol, imposed by Angora on the Armenian Republic of Erivan after Kiazym Kara Bekir Pasha's campaign in the autumn of 1920. They were afterwards confirmed in a third treaty signed at Kars by representatives of Angora and the three Transcaucasian Soviet Republics. For dates see the table at the end of the book.
} 
and that was Greece. Under the treaty signed by the Allies and Turkey at Sèvres on the $10^{\text {th }}$ August 1920 , Greece acquired provisionally a zone round Smyrna which had been assigned to Italy by the agreement of St. Jean de Maurienne, and the whole of Eastern Thrace except the Constantinople Peninsula-including the strip along the Marmara and the Dardanelles assigned to Russia in 1915, as well as the interior. All this was now in her effective possession, and not only this but almost the whole north-west of Anatolia up to the rivers Maeander and Sakkaria, ${ }^{1}$ with the two strategic positions of Afium Kara Hissar and Eski Shehir. This was an extraordinary reversal. In the secret agreements made during the War, Greece had had no share. She had been a small Near Eastern state and an unpopular neutral. And now, in the fourth year after the armistice, she alone could point to substantial acquisitions, while the three self-styled 'Principal Allied Powers,' who had borne the brunt of the fighting and the intriguing in Asiatic Turkey, had got next to nothing in hand, and nothing lucrative at all. This was the fact, but what was its moral? Taking the situation at its face value, a Greek might have been tempted to suppose that his nation had more virility and 'survival-value' than the English, French, and Italians. Here was 'little Greece' making good her treaty rights when greater Powers were waiving theirs, and standing up to the Turkish Nationalists of whom the West had fought shy. The Turks, and their Indian admirers, might have drawn similar conclusions. They, for their part, had got rid of the French and Italian Zones; they had even

\footnotetext{
${ }^{1}$ Except for the Peninsulas of Haidar Pasha and Bigha, which, like the Constantinople Peninsula,
} 
secured the retrocession by France of a long strip of frontier territory, containing the permanent way of the Baghdad Railway, which the Treaty of Sèvres had included in the French mandated territory of Syria; they had recovered from Russia territories which she had taken from them in 1878; and they looked forward confidently to forcing the Greek army out of Anatolia and the Allied garrisons out of Constantinople. This was an unmistakable turn of the tide. Which looked decadent? The West or Turkey?

Many Turks and Greeks have seen things in this light during the last few years. Their consequent exaltation of spirits has been one of the obstacles to a settlement. But in so far as they have thought and felt like this, they have ignored the most important fact in the situation. Whatever the Western Powers had sacrificed in the Near and Middle East, they were none of them any longer at war there, while Greece and Turkey, in the fourth year after the armistice, were fighting with all their might.

Here we have the key to the diplomatic situation. The renunciations made by the Western Powers in the Near and Middle East were neither uncompensated nor involuntary, while the price of her gains was proving ruinous to Greece. The striking inconsistency between the Powers' claims before the armistice and their later policy is certainly damaging to the reputation of the few dozen British, French, and Italian officials and politicians who made the secret agreements. The long tradition of professional rivalry had obsessed them. They were stupefied by the stale, poisonous atmosphere of 1839,1882 , and 1898 , 
which still hung about their consulates, embassies, and foreign offices; and the clandestine and unedifying activities on which they were employing their energies during the most critical moments of the War had little relation to the present or the future. They were completely out of touch with the public opinion of their respective countries. They not only miscalculated the relative values which their public would set upon peace and Oriental annexations after the War. They even misjudged their own ability to coerce or cajole their publics into carrying out their policy.

But the folly of the Western diplomatists has been the measure of the Western public's common-sense. During the War, the Eastern 'side-shows,' though frequently criticised, were rightly regarded as a technical military problem. They were a part of the general conduct of the War, and a comparatively small proportion of our man-power and material resources was involved in them. The public let them be, and the diplomatists made their secret agreements on the supposition that the men and money available in the East for military purposes during the War would remain at their service for political purposes after it. But from the moment of the armistice, public opinion began to assert itself. The main operations on the Western front had been terminated by complete victory; why should subsidiary fronts be kept in being? The soldiers who had been defending the heart of France, Italy, and England were being demobilised; why should their comrades be kept under arms to hold down unwilling populations in outlandish Eastern countries, where neither they nor their families had any interests at stake? And why should the taxpayers, on whom the national struggle for 
existence had imposed crushing burdens, accept further burdens for the sake of their diplomatists' professional struggle for power? The soldiers and the taxpayers revolted against the further expenditure of lives and money to which the diplomatists had secretly committed them. British troops in Transcaucasia and Mesopotamia, and French troops in Cilicia, clamoured to be demobilised; French sailors in the Black Sea refused to operate against the Bolsheviks; Italian reinforcements refused to embark for Albania, not to speak of the Central Desert of Anatolia, which Italian diplomatists had worked so hard to acquire for their countrymen; and there had been a growing opposition in the Press and the Parliaments. Confessions about the strength of the respective military forces in the East, their casualties, their cost of maintenance, and about the budgets of the civil administration in the occupied territories, had been wrung out of unwilling Governments and subjected to unanswerable criticisms.

This internal struggle had been going on simultaneously and with similar fortunes in all three countries. Official resistance had been very stubborn, and at first the unspent momentum of the War and the distraction of the public mind enabled the officials to carry on. They were not prevented from embarking on costly aggressive operations in Russia, though they were forced to break them off; and as recently as the summer of 1920 the French Government found ways and means of conquering Syria and the British of reconquering Mesopotamia. But it was always a losing battle, and the last offensive ended in rout. M. Franklin-Bouillon's agreement with Yusuf Kemal Bey and our own Government's treaty with the Emir Feisal were unmistakable admissions of defeat. 
Substantially, the Western nations have demonstrated their comparative wisdom and strength of character at their representatives' expense. They have reestablished an effective, though belated, limited, and rather negative 'democratic control' over their public servants, and they have realised more quickly than the 'experts' that the days of Oriental dependencies are numbered. Under post-war conditions —especially political conditions—these pieces of property are going to bring in diminishing returns, and their owners, the Western nations, have therefore begun to force their official overseers to liquidate them. ${ }^{1}$ But this victory and defeat are incidents in an internal struggle, and it would be as absurd to treat them as a defeat of Great Britain by the Arabs or a victory of the Turks over France, as it would be to represent the rejection by the American Senate and people of President Wilson's projects in the Old World (which included a mandate over the northern half of Turkey) as a defeat of American by European imperialism. Had she chosen, America could have taken up her mandate as far as the European Powers were concerned; and in the same way Great Britain, France, and Italy were physically capable at the time of the armistice of executing the secret agreements. They had the ships, men, and money to overcome any resistance which could then have been put up by the local populations. The deciding factor was not any stronger 'will to live' on the part of the Greeks, Turks, and Arabs, but the deliberate preference of the British, French, and Italian

\footnotetext{
${ }^{1}$ On the other hand, public opinion may insist on the retention of Tropical African dependencies,
} which will probably remain profitable, and may even have them exploited by methods at which 
peoples to conserve their remaining resources instead of squandering them abroad.

It is necessary to insist on this in order to explain the sequel, for the illusions of the local nationalities have been utilized by the Western diplomatists in order to save something from the wreck of their schemes. The harder they have found it to coax supplies out of their own Parliaments, the more they have turned their attention to other ways and means; and they have found these nations much more 'suggestible' than the comparatively well-educated, sophisticated, and politically experienced public of Western Europe-particularly in regard to Eastern affairs, which involve their national freedom, unity, and honour, while only very speculative material interests are at stake for Frenchmen, Englishmen, and Italians. Greeks and Turks can be swayed and stampeded by visions of 'The City,' 'Ionia,' 'The Abode of Felicity,' or the Holy Sepulchres of Edirné. The herd-instinct can be relied on, as it cannot be in the West, to override the interest and judgment of the individual; and a kind of 'Juggernaut' national personality can be conjured into existence and induced, by offerings attractive to its divinity, to drive over its worshippers' bodies. On the international chess-board such pieces make excellent pawns, and the Western diplomatistswrapped up in their tradition and instinctively using every available means to carry on their professional activities—have not neglected them. 'This is really a battle between England and France.' The Greek and Turkish pawns carried on the game of the French and English players. This pawn-playing, however, has 
not been so odiously cold and disingenuous as an analysis makes it appear. The trap in which the victims have been caught in order to be exploited was not cunningly hidden. They rushed into it with their eyes open because they could not resist the bait. This second phase of Western diplomacy is rather less discreditable to its authors than the secret haggling during the War. There has been less conspiracy about it and more sport, and-most disarming defence-it has been just as stupid. The statesmen miscalculated again. Their fellowcountry-men had the means to carry out their policy but not the will; their pawns had the will without the means. They were too weak to perform the role marked out for them, however great the bribe. They could not struggle on to the eighth square and turn into queens. On the contrary, they have displayed an exasperating faculty of making queens out of the opposing pawns. Greek and Turkish armies, fighting French and English battles, have aroused, and always will a rouse, more resistance than they can overcome.

more high-minded, than its servants. 


\section{GREECE AND TURKEY IN THE VICIOUS CIRCLE}

THE last chapter was an attempt to analyse the post-war problem on the Near and Middle Eastern chess-board. If the analysis was correct, it ought to throw light on the particular roles of Turkey and Greece. A game played with living pieces may be a cruel spectacle, and, half through her own fault, Greece has been the principal victim. The fault is only half hers, for at first she struggled hard not to be drawn into the rivalries between the Powers, and the struggle cost for her internal unity. But instead of common-sense and moderation prevailing, as since the armistice they have begun to prevail in the West, they were overborne by the pressure of the Entente Powers and the imperious personality of Mr. Venizelos; and Greece, more than ever divided at home, was pushed into that 
foreign policy of reckless aggrandisement towards which the blind herd-instinct under the surface of her politics was all the time impelling her. At last, fatally at war within herself and at the same time fatally united for war against a neighbouring nation, she was brought to a point from which she could neither reach internal or external peace, nor retreat without loss or even disaster. The world has sympathised with the personal tragedy of Mr. Venizelos. There is a greater pathos in the national tragedy of his country.

Mr. Venizelos is tragic not on account of his fall, but because of the change of part which was the cause of it. He came to Greece in 1910 in order to banish personal partisanships from her politics. It has been his fate-the fatal conjunction of his country's circumstances and his own character-to reimport into the old feuds a ferocity to which they have seldom been degraded since the worse moments of demoralisation during the War of Independence. ${ }^{1}$ He made his mark as a great peace minister, and like Pitt he left his poor country involved in a desperate war. In the first war through which he guided her destinies, he showed striking moderation in the hour of victory. After the second war, he grasped at such excessive territorial prizes that he failed to secure the greater prize of peace. Being a statesman of great force and great charm of character, he has been able to give ample effect to his policy, and when it has been mistaken, his country has therefore suffered its consequences to the full.

${ }^{1}$ e.g. The civil wars of November 1823 to June 1824 and of November and December 1824. 
There has been a parallel change in the part latterly played in international politics by Greece. At the beginning, Greece distinguished herself from her neighbours by holding aloof from the European War. Serbia had no choice; Turkey and Bulgaria were committed by a few men in power; Rumania's intervention seems mainly to have been decided by party leaders and by Russian coercion, and though made at leisure, to have been not exactly a national decision. In Greece alone of the Near and Middle Eastern belligerents, there was a real canvassing of opinion comparable to the internal struggle which preceded the intervention of a Western nation like Italy, or to the post-armistice struggle in the principal Western Allied countries, alluded to above.

The controversy was brought on by a private offer from the Allied Governments to Mr. Venizelos, at that time premier and at the height of his prestige, of territorial acquisitions for Greece on condition that she intervened on their side. The territories offered were very large—a much bigger zone in Western Anatolia than that provisionally assigned to Greece under the Treaty of Sèvres, and Cyprus in addition-and the scheme, as worked out by Mr. Venizelos, would have diminished the risks of departing from neutrality, for he proposed to purchase the co-operation of Bulgaria (also still neutral) by ceding to her Eastern Macedonia. Yet it was after all a policy of adventure, and nothing but the fact that it suited our interests has made us think ill of King Constantine for rejecting it. The hard things said about him may be true, but his opposition to Mr. Venizelos on this question does not prove them. Neutrality, during the whole period during which we respected the King's legitimate claim to insist upon it, 
was more prudent for Greece, and more dignified, than the purchase of territory by intervention; and it makes for the general betterment of international relations if small states always and everywhere keep as clear as possible of the rivalries between Great Powers. Indeed, King Constantine was not alone in his views. Possibly a majority among the politically educated people in Greece agreed with him, and such sentiment for Germany as really counted in the controversy (its importance has been exaggerated) was natural and proper. Greece had not borrowed Western civilisation only from the three Western Powers that happened to be on one side in the European War. In her eager apprenticeship she had sought instruction from all members of Western society. By the decision of the British, French, and Russian Governments of the day, ${ }^{1}$ her first Western instructors had been Bavarians. Their tutelage was not a success, but a number of them married Greeks and founded families in the country, and the link thus created with Germany as well as with the other Western nations was perpetuated by the intellectual gifts which Greece has since received from her. German archaeologists like Schliemann and Dörpfeld have taught the Modern Greeks how to rediscover the history of their predecessors, and Greek students have gone to German universities as well as to Paris and Oxford. Our murderous civil war in the West naturally produced a mental and sentimental schism in Greece, which contributed to the political cleavage in the country.

\footnotetext{
${ }^{1}$ Convention of London, $7^{\text {th }}$ May 1832.
} 
Thus Greece rapidly became divided against herself, and the conflict took more and more violent forms. There was a bad tradition of violence and personal vendetta in the politics of Greece, which was not surprising considering the suddenness and recentness of her political Westernisation. The miracle was that the Fathers of the Revolution-that incongruous assemblage of peasants and merchants, brigands touched by romanticism, and philosophic Ottoman high officials - had been able to found anything resembling a Western parliamentary state. Considering the initial difficulties, the political development of Modern Greece has been rapid; but she could not be expected to skip stages in the process, and it is not surprising that by 1914 she had not left behind her the spoils system of nineteenth-century America and the personal treatment of politics that prevailed in England before the Reform Bill. Since 1910 she had been making efforts to shake herself free from these anachronisms. The profound disturbance of her internal life by the War has fastened them upon her once more. In a milder form we have been suffering from the same symptoms of political deterioration in Great Britain.

The schism widened quickly. Mr. Venizelos fell. The Allies' offers were declined and withdrawn. Mr. Venizelos returned to power. The Dardanelles expedition failed, the Allies landed an expeditionary force on Greek territory at Salonika, and a few days later Bulgaria entered the War. Mr. Venizelos fell again, and the hostility of the two factions in Greece towards one another mounted up, as they were driven nearer to committing their country to one side or the other in the battle of Great Powers. The Greek Army under the King's 
control menaced the rear of the Entente Army at Salonika, whose intrusion had brought the War on to Greek territory. An army corps handed over Fort Rupel in Eastern Macedonia to the Bulgarians, and surrendered. The Allies retaliated by subjecting Greece to the naval blockades, which produced more speedy and acute distress there than in Germany. On the $25^{\text {th }}$ September $1916, \mathrm{Mr}$. Venizelos left Athens for Krete, went on to Salonika, set up a provisional Government over the Greek territories controlled by the naval and military forces of the Entente Powers, and organised a contingent of Greek volunteers to fight for them on the Salonika front. On the $1^{\text {st }}$ December 1916, there was an armed conflict in Athens, in which Allied soldiers and Venizelist civilians were killed by Royalist soldiers and reservists. On the $11^{\text {th }}$ June 1917 , King Constantine was forced by a French commissioner, M. Jonnart, to abdicate, and a few days later Mr. Venizelos was brought back to Athens by Allied troops. After this coup d'état, his Government-thus established in the capital and placed in control of all Greek territory not occupied by the Central Powers-formally entered the European War as a member of the Entente Alliance. As such, it subsequently presented its claims at the Peace Conference held by the victorious states at Paris.

Every event referred to in the last paragraph raises controversial issues. Did the elections and by-elections of 1915 prove or not that Mr. Venizelos was supported by a majority of the Greek nation? If he was, had the King a right to dismiss and exclude him from office? Did her treaty with Serbia legally and morally bind Greece to fight when Bulgaria intervened? Had the Allies received 
a genuine invitation from Mr. Venizelo's Government to land at Salonika? Which side was morally the aggressor in the fight at Athens on the $1^{\text {st }}$ December $1916 ?$ Was the will of the Greek nation or the military power of the Entente the real cause of Mr. Venizelos's triumph over King Constantine between his flight from and return to Athens? These controversies lie behind the horizon of this book; many of them had only an ephemeral interest; others are incapable of settlement. In particular, it is almost impossible to adjudicate upon the relative strength and merits of the two Greek factions. Each contains a few fine and many inferior individuals and a contingent of bad characters. Neither has a solid hold upon the nation, which has fluctuated between them under the pressure of foreign armies, the fancied interests of the moment, or irrational emotion; and at each turn of the wheel there has been provocation and retaliation. Royalists terrorized Venizelists in 1915 and 1916; Venizelists proscribed and imprisoned Royalists from the coup d'état of the $11^{\text {th }}$ June 1917, down to the elections of November 1920; and after the return of the King, Venizelist placemen were systematically retired, transferred, or otherwise removed to make way for the men whom they had themselves displaced three and a half years before. Each time yet another turn of the wheel has been hoped for and worked for by the temporarily discomfited party, but reversals of party fortunes, when they involve such consequences as these, are nothing but a misfortune for a nation, and Greece cannot begin to rebuild her shattered political life so long as it remains dominated by personal rancours. The point of historical interest is not to pass judgments on these mischievous parties and their unprofitable vicissitudes, but to trace how a 
war between the Western Powers has played havoc with the internal development of a Near Eastern country, and then to observe how this internal disharmony has reacted prejudicially upon that country's foreign policy under a succession of party governments.

At the Paris Conference Mr. Venizelos, on behalf of Greece, put forward startling demands. He asked for the whole of Western and Eastern Thrace up to the Black Sea and the Chatalja lines, and for the entire vilayet or province of Aidin, ${ }^{1}$ in Western Anatolia, with the exception of the one sanjak or department of Denizli, but with the addition of a corridor to the south coast of the Marmara. The first claim meant interposing a continuous belt of Greek territory between Turkey and other European states and between Bulgaria and the Aegean. The second meant taking from Turkey the richest province and principal port of Anatolia, bringing a large Turkish population under Greek rule, and leaving the two nations, with these new seeds of discord sown between them, to face one another along an immense land frontier.

These claims, imprudent in themselves, came strangely from Mr. Venizelos, who had stood for a totally different policy after the Balkan Wars. In 1913 he handed Western Thrace over to Bulgaria, though the coast-line had been occupied during hostilities by the Greek Navy, and he doubted the wisdom of annexing Eastern Macedonia (the lower Struma valley) and the port of Kavala. He realised that Greece must live on good terms with Bulgaria, and that unless

\footnotetext{
${ }^{1}$ Of which Smyrna is now the provincial capital.
} 
Bulgaria had unhampered access to the Aegean, an adjustment of interests would be impossible. In 1915 he was still developing this policy in his proposal to cede Eastern Macedonia to Bulgaria in exchange for Anatolian compensations to Greece. But in 1919 he deliberately took the contrary line; maintained that Bulgaria, by a second aggression, had shown herself incapable of responding to a policy of confidence; and submitted that it was no use attempting to conciliate her in the new settlement. As a measure of justice, she should have an economic right-of-way to some port or ports on the Aegean, but sovereignty over the seaboard, even in Western Thrace, ought to be taken from her and given to Greece.

He made a similar change of front in regard to Turkey. In 1913 he had shrewdly eliminated all land frontiers between Greece and the Ottoman Empire. In Europe he separated the two countries by the assignment of Western Thrace to Bulgaria, and in Asia he took pains to show that the acquisition of the islands of Khios and Mitylini by Greece would not necessarily menace Turkish sovereignty on the neighbouring mainland of Anatolia. The Ottoman Government had insisted so strongly on this danger that although these islands were inhabited by an overwhelming Greek majority and had been conquered by Greece in the first Balkan War, the question was referred for adjudication to a Conference of Ambassadors of the Powers. This Conference awarded the islands to Greece, and there is no doubt that they were largely influenced in doing so by a belief in the good faith and moderation of Mr. Venizelos. Their confidence seemed justified when, some months later, he signed a convention 
with the Porte for the inter-migration of Turkish minorities in Macedonia and Greek minorities along the western littoral of Anatolia. ${ }^{1}$ It was a loyal attempt to assure the Turks that, in pressing her claim to the islands, Greece had nothing in view but a local application in her favour of the principle of nationality-that she had no intention of taking advantage of their strategic position commanding Smyrna, and of the proximity of a powerful Greek minority on the mainland, in order to use them in the future as a 'jumping-off ground' for an imperialistic policy in Anatolia. And then, at Paris in 1919, he justified the Turks' worst suspicions and incidentally endorsed their arguments for the reunion of the islands with Turkey. He not only claimed the mainland province opposite the islands, but actually counted in the population of the islands in supporting his mainland claim by statistics of the Greek percentage in the population, on the very ground (put forward by the Turks in 1913) that mainland and islands formed an indivisible geographical unity!

In fact, at Paris the only vestige of Mr. Venizelo's old statesmanship was his handling of the Straits and Constantinople. He ostentatiously refrained from claiming either the city or the territories immediately commanding the Bosphorus and the Dardanelles, on the express assumption that they would be placed under some international régime. He saw that Greece would be involved in dangerous conflicts of interest, especially with Russia and the other Black Sea riverains, if she acquired the sovereignty over these strategic positions, and that on the other

\footnotetext{
${ }^{1}$ See Chapter IV., p. 141, below.
} 
hand the Greek element in Constantinople would become the dominant local nationality if Ottoman sovereignty came to an end and Greece stretched up to Chatalja. But why, if he realised this, did he ignore the still greater dangers in which he was involving Greece by his policy towards Bulgaria in Thrace and towards Turkey in Anatolia? If the governing consideration in the Thracian case was the alleged implacability and incorrigible aggressiveness of Bulgaria, and if friendship with her had been proved impossible by experience, then he ought to have aimed first at securing for Greece the best possible strategic frontier. Instead of that, he proposed a settlement which would produce the longest possible land frontier between the two countries, and would put all the strategical advantages on Bulgaria's side. In regard to Turkey, again, the desirability of avoiding a common frontier and of interchanging the minorities had surely been re-demonstrated rather than disproved since 1913. The Turks had shown themselves bellicose and merciless to minorities. A straggling land frontier in Anatolia as well as in Thrace would be a permanent military anxiety, and though the local Greek minorities stood to gain if Greece acquired the province of Aidin (for they could be protected without having to emigrate), the much larger minorities scattered through the interior and remaining under the Turkish Government's power would be exposed to greater danger, as in the event they have been exposed—with deplorable consequences. ${ }^{1}$

${ }^{1}$ See Chapter VII. 
What had happened to Mr. Venizelos? Before the formal presentation of his claims to the Council of Ten, he expressed unlimited optimism about the practicability of carrying them out. He refused to admit that in opening the Anatolian question he was implicitly reopening the question of the islands; maintained that the Greek Army could hold his projected Anatolian frontier on a peace-footing; and suggested that so long as they were given economic outlets to the sea, Bulgaria and Turkey would be reconciled to the losses of territory and population which he hoped to inflict upon them. Had he simply been infected by the hysterical atmosphere of the Peace Conference? Had the sudden passage from the verge of defeat to apparently absolute victory blinded him to the fact that the momentarily prostrate enemy nations would some time become Powers again? Had his head been turned by his Western colleagues' recognition of his personal qualities? All these things happened to other prominent members of the Conference, but it is difficult to believe that a statesman with such a long experience, such a record of liberalism and moderation, and so much intellectual originality and strength of will, can have based an elaborate programme upon passing impulses and emotions. These may have weakened his judgment, they can hardly have overthrown it. The less improbable explanation is that his optimism was largely feigned, that he was taking the risks with his eyes open, and that his policy was decided partly by some force majeure and partly by the expectation that the dangers, while real, could be discounted by some effective means of insurance. 
The force majeure is not far to seek. It lay in the necessities of Greek internal politics. Mr. Venizelos must have known-what his Western colleagues never realised - that his position at home was precarious. He had only been brought back into power by foreign bayonets; he had had to intern or exile many hundreds of his leading opponents in order to maintain himself; and it was doubtful whether the country was behind him. He had not to deal with the comparatively sober and united nation which had followed him from 1910 to 1914, but with a nation exasperated by suffering and faction and then demoralized by unexpected success. If he had not exploited this tremendous opportunity to the utmost-if, besides Constantinople, he had renounced other great traditional (and non-party) national claims-the Royalists might have cried 'Traitor,' and who knows if Greece might not have echoed them? If, on the other hand, he succeeded, by his undoubted personal magnetism and prestige, in obtaining for his country even more in Thrace and Anatolia than the ordinary patriotic public expected, he might prolong his tenure of office for an indefinite period and devote all his abilities to warding off the dangers which the necessities of the moment bade him incur. The post-armistice period was an 'acid test' for all Entente politicians then in power. Reason and honesty were more important than they ever had been in politics, but it needed high moral courage to act up to them. Was there the same failure of nerve in Mr. Venizelos as in Mr. Lloyd George?

Possibly the idea of finding insurance for his risks took shape in Mr. Venizelo's mind during his intercourse with Mr. Lloyd George at Paris. 
Undoubtedly Mr. Lloyd George was more responsible than any other representative of the 'Principal Allied Powers' for the substantial triumph, at the Conference, of Mr. Venizelos's claims. From that time onwards, the personal attitude of Mr. Lloyd George became one of the most important factors in the Graeco-Turkish conflict. But the British Prime Minister's views are not always to be found in the official documents which will eventually pass into the Public Record Office, and there is no reason to expect that he will ever write an illuminating autobiography. The play of his mind in regard to Turkey and Greece will therefore probably always remain a matter of conjecture, and as we cannot leave it out of account, we must make the best guesses that we can.

Why did Mr. Lloyd George back Greece at the Conference, and go on backing her, with unusual constancy, when to all appearance he was losing on her? One must allow something for sentiment—uninformed religious sentiment on behalf of Christians in conflict with non-Christians, and romantic sentiment towards the successors of the Ancient Greeks. He is reported to have read something late in life about the Hellenic or 'Ancient Greek' civilisation, and to have been influenced by the identity of name. The words 'Christian' and 'Greek' possess a magical power of suggestion - the political bearings of which are discussed in Chapter VIII. It is no insult to suppose that the Prime Minister's sentiment rested on common fallacies, if we assume that it was sincere as far as it went. But it would be wrong to treat it as other than secondary to practical calculations, and there is reason to believe that he calculated as follows: The British Government cannot keep troops mobilized in the East to enforce eventual 
terms of peace upon Turkey; Greece can provide the troops and enforce the terms with British diplomatic and naval backing, and she will gladly do so if these terms include her own claims. If Greece makes these claims good through British backing, she will have to follow Great Britain's lead. She is a maritime Power, a labyrinth of peninsulas and islands, and the territories that she covets in Anatolia are overseas. In short, if Turkey can be dominated by the sea-power of Great Britain, and so the British Government can still carry out their war-aims in the Near and Middle East without spending British money and lives.

Subsidiary motives may have entered in. From what is known of Mr. Lloyd George's character, it may be guessed that the immediate practical problem of finding some military substitute for British divisions which had to be withdrawn from the Caucasus, the Straits, and Syria, was more present to his mind than any general principle of policy for the future. In his mind, the general appears to flower out of the particular by some esoteric process. Incidentally, his policy on this occasion smothered the awkward question of Cyprus. Eighty per cent. of the population of Cyprus are Greeks who want to be united with the Greek Kingdom; the British Government had no case for incorporating the island in the Empire; ${ }^{1}$ yet since the armistice they had shown no inclination to give it up. But if Greece were acquiring vast territories elsewhere with Great Britain's assistance, the

\footnotetext{
${ }^{1}$ Under the Cyprus Convention, secretly negotiated between the British and the Ottoman Government on the $4^{\text {th }}$ June 1878 (between the Treaties of San Stefano and Berlin), Turkey consented to the occupation and administration of Cyprus by Great Britain so long as Russia retained Kars, Ardahan and Batum, Great Britain undertaking in return to resist further Russian
} 
Greek Government at least would be debarred from taking up the Cypriots' cause and creating an open international scandal. There were many possible motives on Mr. Lloyd George's side for coming to an understanding with Mr. Venizelos. Did the Welsh and the Kretan statesmen deceive themselves or one another? Something was wrong with their calculations, for the bargain turned out badly for both. Probably each deceived himself, and that by overestimating the other's power, in contingent circumstances, to perform more than his bond. Whatever the mutual understanding was (and it may never have been precisely formulated), one need not suppose that either actually promised more than he could perform or expected that their joint contributions would be insufficient to bring about their combined aims. On the other hand, one cannot believe that either was blind to the risks jointly incurred. Unexpectedly effective opposition from the Turks, the Russians, or one or the other of the Allies might render the contemplated Greek military effort unequal to their task, and here some selfdeception may have come in. Each party may have been reckoning, for insurance, upon greater efforts being forthcoming, in case of need, from the other when once committed to action. If Mr. Venizelos were playing for Thrace and Smyrna, would he hesitate to borrow a few more millions, send a few more divisions, sacrifice a few more lives in order to win the game? And if Mr. Lloyd George were playing for ascendency in the Straits and indeed throughout the Levant, would he not in the last resort reinforce the Greek Army with his own to gain so great a prize? So Mr. Lloyd George and Mr. Venizelos may have 
calculated respectively in their private thoughts, for it is evident that neither realised the limits of the other's power over his fellow-countrymen. The British Premier ignored Greek party-politics; the Greek Premier ignored the limiting veto possessed and since exercised by British public opinion over the commitments of His Majesty's Government in the East.

This is, and only can be, conjecture, but at any rate it offers a reasonable explanation of what actually occurred; for if these two statesmen's minds did work in the way suggested, one can see how circumstances conspired to give their policy its opportunity. Sir Arthur Balfour, with a less naïve appreciation of Ancient Greece than Mr. Lloyd George, may have been tickled by the conceit of Modern Greek 'harmosts' administering 'lonia.' President Wilson was ignorant and flouted his able expert advisers. M. Clemenceau, always symbolic, adopted the characteristic Western attitude towards the 'Eastern Question.' He thought it tedious and unimportant, and was ready to humour his colleagues when Mosul and Smyrna were on the agenda in order to be all the more obstinate over the Saar, the Rhine, and Reparations-somewhat in the spirit in which insurance companies pay small claims and fight big ones. On this tack he was prepared to go to the utmost lengths which the small but energetic Colonial Party in France permitted. Mr. Venizelos adroitly smoothed M. Clemenceau's path by sending two Greek divisions to fight the Bolsheviks in Southern Russia during the early winter months of 1919, a job against which the French Navy mutinied. It was an earnest of what he could get his countrymen to do, on the mere expectation of 
favours to come, in a cause which appealed to French bondholders. Even if the French Government had foreseen all the consequences, they could hardly have raised opposition when, a month or two later, the very Greek troops which had served French policy at Odessa were shipped off to serve Greek and British policy at Smyrna.

The fatal decision was precipitated by the public disagreement between Italy and the other Powers over the Adriatic. On the $24^{\text {th }}$ April 1919 , the Italian Delegation withdrew from Paris. They were back again by the $5^{\text {th }}$ May. But lovers' quarrels between statesmen in Western capitals may produce more serious breaches of amity between their representatives in the Near and Middle East, who have been trained in jealousy for generations. On the $29^{\text {th }}$ March, the Italian claim in Anatolia had been staked out by a naval and military occupation of Adalia, and during the interregnun at Paris the Italian forces began to occupy one point after another on the coast from Adalia northwestwards in the direction of Smyrna. The diplomatists came back, but the occupations went on, and the local representatives of the other Powers took alarm. Smyrna was at Italy's disposal according to the agreement of St. Jean de Maurienne, and the installment of an Italian garrison there would more than compensate for flaws in the legal validity of a scrap of paper. The only certain way to keep the Italians out was to forestall them. Could this be done under the armistice, signed on the $30^{\text {th }}$ October 1918, with Turkey? According to Article 7 of this instrument, 'The Allies have the right to occupy any strategic points in the event of any strategic situation arising that threatens the security of the Allies.' That was good enough, 
but what troops to send? The telegrams passed to and fro between Constantinople and Paris, Mr. Venizelos saw his opportunity, and the 'Big Three' took their decision. The Porte was informed that Allied troops were to be landed at Smyrna for the maintenance of order. An Allied naval squadron left the Bosphorus for Smyrna, with Admiral Calthorpe, the British High Commissioner, in command. The local Allied control-officers were instructed to disarm and remove the Turkish troops remaining in the city, in accordance with Articles 5 and 20 of the armistice. In the act of compliance, the Turkish authorities were troubled by a rumour. The troops that were to be landed next day were Greek! They made urgent inquiries from the control-officers, and were simply informed that the troops would be 'Allied,' as announced already. The answer, technically correct, was of course a deplorable prevarication. The Greek troops went on shore, under the guns of the Allied warships, the following morning.

Various consequences of this landing occupy most of the remaining chapters in this book. The diplomatic consequences may conveniently be narrated here in anticipation. Within he first few weeks, so much bloodshed and destruction occurred that the Allied and Associated Governments sent a commission of senior officers, under the presidency of Admiral Bristol, United States High Commissioner at Constantinople, to put a stop to the fighting and establish the responsibility for the atrocities already committed. But the mischief could not be undone so easily. The Commissioners arranged an armistice line; they could not demobilise the forces already opposing one another in this new war. They reported on the crimes committed, but their report has never been 
published by their Governments. ${ }^{1}$ Possibly they were tactless. It may have been difficult to indict Greeks and Turks who had killed, burnt, robbed, and violated in the vilayet of Aidin without reflecting upon statesmen who had made decisions at Paris. There is no doubt that the 'Big Three' were morally as well as technically responsible for the consequences of this particular decision, for they cannot plead that they were badly informed. The suggestion of a Greek landing at Smyrna had been aired in official circles for some weeks before it was carried into effect, and had evoked emphatic comments and forecasts from the local representatives of the several Powers who were controlling the execution of the armistice on the spot. These representatives cannot be blamed for having reported, as they were in duty bound to do, the danger of an Italian coup de main upon Smyrna. They could not know the diplomatic situation at Paris, or foresee that a Greek occupation would be the safeguard selected by their Governments. The 'Big Three' were responsible, and if any of them demur to this, they can be challenged to publish, or to invite their successors in office to publish, the official information on which they acted, as well as the Bristol Report. Their unwillingness to publish the report is not incomprehensible, and besides, Mr. Venizelos threw all his personal influence into the scale. He objected to the publication of evidence which had been taken by the Commission without the presence of a Greek assessor, and in which the names of the witnesses were

\footnotetext{
${ }^{1}$ Unofficial versions of their findings are current.
} 
withheld. ${ }^{1}$ There was, of course, a good reason for this, which reflected on the local Greek authorities and not on the Western Commissioners. The individuals giving damaging evidence against the Greeks were living under a Greek military occupation and could not safely be exposed to reprisals. There were the same legal flaws in the Bryce Reports on Alleged German Atrocities in Belgium and on The Treatment of Armenians in the Ottoman Empire. Did the Allied Governments hesitate to publish these documents on that account? And so, on the $10^{\text {th }}$ August 1920 , when the atrocities committed by the Greeks at their landing were fifteen months old and the war which they had started had spread far into the interior, a treaty of peace with Turkey was signed at Sèvres—by plenipotentiaries unrepresentative of all the implicated nationsunder which a zone on the mainland of Anatolia round Smyrna was provisionally assigned to Greece (Articles 65-83). It was a very much smaller territory than that which Mr. Venizelos had originally claimed, but even if his claims had been granted in full, the consequences for Great Britain and France, for Turkey and

\footnotetext{
${ }^{1}$ On the $22^{\text {nd }}$ March 1920, the following answer to a question by Earl Winter ton was given in the House of Commons by the Prime Minister:--

'His Majesty's Government . . . consider it inadvisable to allow the Report of the Commission in question to be published owing to the conditions under which the inquiry was conducted. As the Commission was investigating charges against the Greek Army, the Supreme Council decided that a Greek officer should be allowed to follow the proceedings, but not to vote or take part in the preparation of the Report. The Commission, however, when it began its inquiries, decided not to allow any Greek representative to be present, on the ground that Turkish witnesses might be afraid of giving evidence. M. Venezuelans immediately protested against this proceeding on the ground that it was contrary to the rules of justice in every civilised country that charges should be investigated and witnesses heard without the accused person being allowed to know the charges and the evidence against him. The Supreme Council were of opinion that M. Venezuelans' protest was justified, but before it could alter the procedure the inquiry was completed. Inasmuch as it has not been possible to communicate to the Greek Government the evidence against them
} 
Greece, for Mr. Venizelos himself and eventually perhaps even for Mr. Lloyd George, could hardly have been more unfortunate.

Poetic justice got to work quickly. Mr. Venizelos fell only three months after the treaty was signed, and the return of King Constantine led to an open rift between France and Great Britain.

The position of Mr. Venizelos in Greece has been so little understood in Great Britain and France that his fall has been regarded as inexplicable. No doubt he partly suffered for being ahead of his fellow-countrymen. The police regulations against furious driving and cruelty to animals which he introduced at Athens were as unpopular as the similar innovations of the inter-Allied police at Constantinople. The lawyers worked against him at the elections because he insisted on their liability to military service. The families of the influential politicians, officials, and officers whom he had interned or exiled were naturally his enemies; and during his prolonged absence at the Peace Conference in the West, his henchmen exercised something like a reign of terror at home. Mr. Grýparis, who was the Kretan chieftain's mighty man of valour, is stated to have silenced Royalist deputies in the Chamber at the point of his revolver, and the murder of Mr. loánnis Dhraghúmis by Kretan ‘Special Constabulary' as he was driving into Athens from the country was only a particularly shocking instance of a régime of violence—unhappily more durable than party fortunes—from which prominent Venizelists had also suffered previously to June 1917 and have suffered again since the change of government in 1920. But these causes of 
unpopularity were either petty or were confined, in their direct operation, to a comparatively small section of the population. They do not account for the sweeping success of the anti-Venizelist parties in the elections of November 1920. However influential their partisans may have been individually, they were not numerous and they were out of power. Simple superiority of electioneering organisation could not account for the solid anti-Venizelist vote in remote rural districts. There must have been some general and impersonal grievance against Mr. Venizelos of old standing. It cannot have been war-weariness, for after Mr. Venizelos's fall, Mr. Goúnaris's ${ }^{1}$ Government were able to carry on the war under more discouraging conditions on a larger scale, calling one class after another to the colours. War-weariness did not begin to dominate the internal political situation till the late summer of 1921. In fact, Mr. Venizelos's fall was not the direct consequence of his policy at the Peace Conference. Rather, that policy was an unsuccessful attempt to placate a feeling against him to which his subsequent fall was due.

This feeling is not yet generally realised in England, but it must have been evident to any Englishman who has travelled since in Greece. The Greek nation cannot forgive Mr. Venizelos for having resorted to foreign support against his political opponents. They do not so much resent the steps taken by Great Britain and France to force Greece out of her neutrality. They recognise that our vital interests were at stake, and that at the Peace Conference we did our best to make amends for previous injuries perhaps pardonably afflicted. But they 
cherish their right as an independent nation to have remained neutral during the European War if they chose. Their right to this was just as precious (though more difficult to exercise, owing to their weakness and their geographical proximity to the theatre of war) as the right of the United States. But whereas America did make up her mind freely and intervened when she thought good, Greece had her hands forced by Mr. Venizelos. The King's policy may have been wrong, but Mr. Venizelos had no business to associate himself with foreign Powers in coercing him. The Commander of the Allied Army at Salonika, in the situation in which he found himself, may have been justified by military necessity in exacting guarantees from the Greek Army; but Mr. Venizelos ought never to have let himself be reinstalled in the government offices at Athens by an Allied expeditionary force. The fact that his pro-Entente policy put Greece on the winning side does not diminish the objection to the precedent that he has established for the treatment of Greek sovereignty by Great Powers; and violations of right are not made less humiliating by patronizing payments in compensation. The territorial acquisitions of Greece under the Treaty of Sèvres are regarded by the Greek nation as their due, by virtue of the principle of nationality, and though they may be mistaken about the application of this principle, it is surely the proper basis on which such claims should be considered. Greece could not, with any self-respect, accept Thrace and Smyrna as rent for the damage caused by the passage of the European War, any more than Belgium could accept the offers which accompanied the German ultimatum. Still

\footnotetext{
${ }^{1}$ I have spelt this well-known name in the usual way, instead of 'Gunneries.'
} 
less could she accept them as a personal tribute to Mr. Venizelos for his eminent services to the Allied cause and his distinction of character. This view, however, was ventilated in the French and British Press, if not among responsible officials and statesmen, whenever the Greek claims were discussed, and especially at the time when the Treaty of Sèvres was signed and published. This exasperated Greek public opinion, and when a few months later the accident of King Alexander's death gave it the opportunity, it is not surprising that it expressed itself as it did. Mr. Venizelos failed in Greece for the same fundamental reason as Generals Kolchak and Denikin and Wrangel in Russia, and foreign intervention did the same service to King Constantine and Mr. Goúnaris as to Trotsky and Lenin.

The return of King Constantine brought to light a divergence between French and British policy in the Near and Middle East, which had been growing during the long and laborious incubation of the treaty which was supposed to embody their common policy. It arose directly out of the joint decision of Mr. Lloyd George and M. Clemenceau to disembark Greek troops at Smyrna in May 1919 , and it is a striking instance of sinister reflex action produced by Western interference in the East upon the internal relations of the Western world.

Whose fault was the divergence? It is not so easy to say. By the end of 1921, France had obviously reversed her policy, while Great Britain had changed hers little and that unwillingly. But passivity is no proof of virtue. The original joint policy—which was the British Prime Minister's policy—may have been wrong from the start; or circumstances may have altered; or at any rate the 
reasonable interpretation of the situation may have been modified by experience. It may or may not be possible to justify the change in French policy, but at least it is not difficult to explain it.

In the first place, France had obtained no relief for herself in the East by the employment of Greece as a pawn. On the contrary, she had had additional burdens thrown upon her soldiers and taxpayers. The disembarkation of the Greek troops at Smyrna did not merely produce a guerilla warfare in the hinterland. It created the Turkish National Movement, which rapidly secured control of the whole interior of Anatolia with its military resources. ${ }^{1}$ The new Nationalist organisation set out to recover for Turkey, if necessary by force of arms, all territories inhabited by non-Arab Moslem Ottoman majorities, and the French were in occupation of such territories on the northern borders of Syria. Nationalist forces attacked the weak French garrisons here in January 1920, and France found herself involved in a costly campaign in difficult country. She tried many expedients. There were repeated changes of command; at one moment the Cilician Armenians were given arms and encouraged to hold the front; at other times they were held in leash, the Turks in the occupied territory conciliated, and temporary truces arranged with the enemy. In attempting to escape from an unwanted military burden, France heedlessly embroiled the local nationalities with one another, and made it almost as difficult for them to live together after her evacuation as it has been made in the territories temporarily

${ }^{1}$ See Chapters V. and VI. 
occupied by Greece in Western Anatolia. But these precarious provisional arrangements did not solve the problem, and all the time the resentment at the drain of French lives and money was mounting up at home. It became clear that the drain could only be stopped by coming to terms with the Angora Government over the future frontier between Turkey and Syria, and this was the main object of the agreement signed by M. Franklin-Bouillon and Yusuf Kemal Bey on the $20^{\text {th }}$ October $1921,{ }^{2}$ nearly two years from the beginning of the Cilician campaign. In this agreement France conceded practically all the Turkish demands. ${ }^{1}$ She not only undertook to evacuate Cilicia, which was left under Turkish sovereignty by the Treaty of Sèvres. She also retroceded a large strip of territory (mainly inhabited by non-Arab Moslems) along the northern fringe of Syria. It is noteworthy that this territory contains all the strategic positions essential for the defence of Syria towards the north-for instance, the Amanus tunnel, the railway bridge over the Euphrates, and practically the whole track of the Baghdad Railway east of the tunnel, except the loop where it runs down to Aleppo. The French 'will to power' in the East had become so weak that the French public preferred to hold Syria by the goodwill of the Turks, in order to avoid military commitments on the frontier altogether, rather than to hold it by their own military strength along the line where it could be held thus with the minimum of effort.

\footnotetext{
${ }^{2}$ Published, with an English translation, by the British Government as a White Paper (Turkey No. 2) $(1921)=$ Cod. 1556).

${ }^{1}$ The only important concession made by the Turks was that Alexandrite should be left to Syria, with provision for the linguistic and cultural autonomy of the Turkish element there.
} 
The Greek landing at Smyrna created no corresponding problem for Great Britain, for though Mesopotamia and Turkey had been left with a short common frontier, east of the Tigris, by the dispositions of the Treaty of Sèvres, the contact was only nominal. The line ran through tribal hill-country-a no-man's land in which neither Ottoman, British, nor Arab authority was effective-and the Turkish Nationalists had too much trouble with the Kurds to attack the Mesopotamian plains on the other side of their fastnesses. It is one of the ironies of FrancoBritish rivalry that French jealousy was the cause of this British immunity, for till within two months of the first Nationalist offensive, the British Army had been responsible for the defence of Northern Syria. The Anglo-Franco-Arab forces which overthrew the Turks in Palestine, in the autumn of 1918, and forced Turkey to sue for an armistice, had consisted mainly of British and Indian troops and had been under General Lord Allenby’s supreme command. When Syria and Cilicia were occupied, this arrangement was continued; Lord Allenby remained in supreme command over the zones respectively garrisoned by the several Allies, and British and Indian garrisons actually held the dangerous outpost at Marash, among the hills. But as the Peace Conference procrastinated over the settlement of Turkey, French opinion became more and more uneasy about this interim régime. A condominium in Egypt had once resulted in a solely British ascendency. ${ }^{1}$ Was history to repeat itself in Syria? Already Mr. Lloyd George

\footnotetext{
${ }^{1}$ The merits of the old controversy over Egypt are beside the point. The effacement of France may have been her own fault, Great Britain may have been blameless. The relevant point is that
} 
had persuaded M. Clemenceau into parting with Mosul, which had been assigned to the French sphere under the secret agreement of 1916. The British Government was no less committed to its Arab allies than to France, and Prince Feisal's army was in occupation, under Lord Allenby, of all Eastern Syria. Pressure was put upon the French Government by French opinion to bring the interim arrangement to an end, and the British Government wished nothing better. They had no intention of making a breach with France by themselves seeking a mandate over Syria; they could no longer defend in Parliament their expenditure upon a prolonged occupation from which the country was to derive no benefit; and they were anxious to get rid of their responsibility for keeping the peace before the French and the Arabs came to blows. Agreement was therefore easy, and in November 1919 the British garrison at Marash was replaced by French troops, the British forces retired from all places north of the northern boundary of Palestine, and Lord Allenby's command over the French and Arab forces came to an end. Thus the French had incurred their new military commitments in Cilicia deliberately, and their unfounded suspicions of British policy in Syria were to blame, as well as the real errors of British policy in regard to Greece and Turkey. But this truth, besides being unpalatable, offered no practical solution, but the British Government could not have sent their troops back to Cilicia even if the French Government could have brought themselves to ask for them. The line of least resistance for France was to come to terms with coloured the French view of the situation in Syria. 
the Turks and to put all the blame on the British, and in effect this is what the French Government did.

Indeed, one of the direct motives for the reversal of French policy in the Near and Middle East was hostility towards Great Britain, through fear that she might gain a permanent predominance in the old competition between the two Powers. Since the beginning of the War, she had secured a formidable lead. She had become patroness of the Arab National Movement; she had displayed a military power which overshadowed the Eastern effort of France; the knock-out blow to the Turks had been delivered by a British commander; and now Mr. Lloyd George's policy of partnership between British sea-power and Greek power on land promised a British ascendency not only in the Black Sea Straits but over Greece and what was left of Turkey. There is no evidence, of course, that any such British ascendency—to the exclusion of Italy, France, and America—was in Mr. Lloyd George's mind. It is much more likely that he was simply trying to coordinate the available means for controlling the situation, without clearly distinguishing for whose benefit the control would be exercised. This particular disadvantage of his policy from the French point of view could have been avoided if, from the moment $\mathrm{M}$. Clemenceau had accepted it, the French Government had worked for it as energetically as the British did. But they did not do so, partly because they had not originated the idea, and partly because the whole intention was to saddle Greece with the military effort and to limit the Allies' liabilities to naval and diplomatic contributions. The French Government could no more embark on fresh military operations in the Aegean area than the 
British, but at the same time they could hardly make an equal naval and diplomatic contribution. British prestige and British naval power were both far greater than French in the East after the armistice. In practice, the Allied contribution to the policy was bound to come principally, as the idea had come originally, from the British side; and therefore, if the policy were successful, the Greeks would look on the British as their benefactors and the Turks would look on them as their masters. Automatically, the role of France would dwindle and French influence tend to be effaced.

This influence-in the fields of diplomacy, finance, and culture-is the commodity traditionally at stake in Western rivalries in the Near and Middle East, and in this as in other spheres contemporary France clings anxiously to the assets to which she regards herself as entitled. During the twenty years before the armistice, her cultural property in the Ottoman Empire had been trespassed upon by Germany; indeed, she had been violently evicted from it by Germany after the outbreak of war. She had a cultural Alsace-Lorraine to recover in the East as well as a political Alsace-Lorraine in Europe, and in both cases she wanted an 'integral' restitution. She regarded both assets as her property, and the acquisition of them by others as robbery, and on the whole it is less odious to be robbed by one's enemies than by one's allies. That is perhaps the fairest statement of the French point of view. One might put the same thing in another way by saying that France was eager to step into Germany's shoes and appropriate her monopoly of influence over Turkey by carrying on the German policy of diplomatic cajolery, intellectual bedazzlement, financial control, and 
studied disinterestedness in the Ottoman Government's treatment of subject populations. But this less charitable formulation is also really less correct, for the German policy was nothing but the policy invented for France nearly four centuries ago by Francis I. and habitually practiced by her till Wilhelm II. filched it from her. Whether the desire of France to revive it on her own account was creditable to her may be questioned; but, rooted as it was in a sense of property, and in an old national tradition, the impulse was not so easy to restrain as if it had been a new ambition.

These were the French motives. They were reinforced by the collapse of the last 'White' movement in Southern Russia in the autumn of 1920, for if the Bolsheviks could not be destroyed by civil war they might still be kept at bay by the hostility of neighbouring nations. French publicists began to think of Turkey as an Eastern Poland. In fact, a French policy took shape for using Turkey against Russia in much the same way as Mr. Lloyd George was already using Greece against Turkey.

As for the recall of King Constantine to Greece by plebiscite, which occurred a short time after the flight of General Wrangel's army from the Crimea to Constantinople, it was not a motive but a pretext for the reversal of French policy, and France would not have reverted to the 'Lloyd George policy' to which she had been committed by M. Clemenceau, even if the King and all his supporters had been turned out and Mr. Venizelos set up again, before $\mathrm{M}$. Franklin-Bouillon had begun to negotiate his agreement. The change of government in Greece was a welcome screen for the somewhat risqué 
metamorphosis in which French policy was already engaged. The screen was not wholly transparent. The French public did genuinely dislike seeing a brotherin-law of the ex-Kaiser reascend a European throne; and they did mind the death of the French marines killed by Royalist Greek troops at Athens on the $1^{\text {st }}$ December 1916. But one can either stimulate or check such feelings. When the Franklin-Bouillon agreement was made public, it was not swept away by public indignation with the Turkish Nationalists for the treacherous killing of Frenchmen (in this case, prisoners of war) during the recent campaign. Nor was France unduly perturbed by the armed raids of the ex-King Charles of Hungary, though they were far more dangerous to the Versailles settlement than King Constantine's constitutional restoration. The French had been looking out for a grievance against Greece, and they had found it. They could not be expected to relinquish it readily.

Great Britain, on the other hand, would not readily relinquish the policy initiated by her Prime Minister. He, too, wielded a screen (the diplomatist's substitute for a buckler). In his case it was the protection of the Christian minorities hitherto subject to Turkey, and here also there was a traditional public sentiment to give the diplomatic form some substance. It is true that the Greek campaign in Anatolia was having the opposite effect to that generally assumed in Great Britain. The minorities in the occupied territories were being compromised and the more numerous minorities in the vast unconquered interior exposed to 
reprisals. ${ }^{1}$ But public feeling is no more rational in England than in France. It is inclined to take satisfaction in the liberation of one Christian from Moslem rule, even if this involves the subjection and oppression of ten Moslems on the spot and the massacre of two Christians at a distance. It takes it for granted that the liberation of Christians is always and everywhere an application of the principle of nationality, just because it was so on the whole in the territories taken away from Turkey between 1814 and 1913. It does not face the fact that in Anatolia, where the Christians are in a minority, the two things conflict and can only be promoted at the expense of one another. Nor is its faith shaken by atrocities, for a majority of people in England believe that atrocities are committed only by Turks, an that daily, while the rest mostly believe more or less the same thing about Greeks or Bulgars. Every report of fresh atrocities committed by members of one or other Eastern nationality therefore simply strengthens the existing anti-Turk or antiGreek or anti-Bulgarian persuasion, as the case may be. As people read of them, they have the double luxury of being confirmed in their views (for they seldom read the other side) and of giving way to moral indignation. They write to the Press or petition the Government to take active measures against the offending nation. They rarely reflect that previous measures of the kind for which they appeal may have provoked the very atrocities which have just aroused their feelings. Because they are indulging their feelings, and not using their reason as they would use it in circumstances where they are more directly responsible for

${ }^{1}$ See Chapters VII. and VIII. 
what was to be done, they thirst for vengeance and forget to look for remedies. Thus they overlook the obvious and fundamental fact that atrocities are committed in similar exceptional circumstances by people of every nation and civilisation, and that whatever may be the duties of Governments, the mission of philanthropists is not to punish crime but to remove its cause. ${ }^{1}$

This was the sentimental link between British public opinion and Mr. Lloyd George's policy towards Turkey and Greece, but it was no more the motive for the British Government's constancy than hostility to King Constantine was for the French Government's volte-face. In either case sentiment screened supposed interest, and British policy was slow to change because co-operation with Greece against Turkey did, on a short view, seem better calculated to serve the interests of Great Britain than those of France. The Greek campaign in Anatolia did temporarily lighten for the Allies the task of controlling the Black Sea Straits, and Great Britain cared more about the maintenance of this control than France-not, as the French supposed, because she aimed at a monopoly of political and naval ascendency there, but because the British carrying trade with the Black Sea riverains through this waterway had been more important than the French before the War. The British nation hoped to renew this trade at the earliest opportunity. The French, intending to make no peace with the Bolsheviks until they honoured the debts of the Tsar, were comparatively indifferent as to whether the commercial route were open or closed. Indeed, they might prefer to see it

\footnotetext{
${ }^{1}$ See Chapter VII.
} 
closed, if that would bring additional pressure to bear upon Russia. Thus there was a positive British interest to be served by employing Greece as a pawn, and in the summer of 1920, when the Asiatic shores of the Straits were actually threatened by the Turkish Nationalist forces, Mr. Venizelos did play his part according to the understanding. Without any expenditure of British money or lives, the littoral of the Straits was cleared by the Greek Army's advance and the Nationalists driven away into the interior. ${ }^{1}$ This was a substantial service, and the British Government, who had accepted it in order to extricate themselves from an awkward position, were committed by it more deeply than before to the Anglo-Greek entente in virtue of which it had been rendered. The Greek Army was so immediately convenient that British statesmen ignored the fact that its presence in Anatolia had really created the hostile movement which it showed such obliging readiness to combat, and the still more serious fact that this movement was potentially stronger than the force which had called it into being. They only slowly realised that the Greek military position in Anatolia must ultimately prove untenable, and that when the inevitable evacuation occurred, the Straits would not only be left uncovered but might be exposed to attacks from a military Power driven into hostility towards Great Britain on account of her support of Greece-a Power which did not exist at the time of the original Greek landing at Smyrna. ${ }^{2}$ Meanwhile, it had become difficult to change and doubtful whether any change at this stage could heal the rift between a Greece backed by

\footnotetext{
${ }^{1}$ See Chapter VI.
} 
Great Britain and a Turkey backed by France. This rift had disastrous effects upon the local situation, because it made the French and British Governments impotent, on the few occasions when they attempted it in a half-hearted way, to arrest the mischief for which they were jointly responsible.

On the $21^{\text {st }}$ February 1921 the three Western Allied Governments and the Japanese Government held a conference in London at which the Graeco-Turkish problem was the first item on the agenda, and the Government of Athens, Constantinople, and Angora ${ }^{1}$ were invited to send delegations. After listening to statements of the Greek and Turkish case, the Allied statesmen laid before each party the following proposal:--

'Viewing the difference of opinion that has arisen concerning the populations of Eastern Thrace and Smyrna in the areas assigned to Greece by the Treaty of Sèvres, the Powers are willing to refer the question of the populations of those two areas to an International Commission to be appointed by themselves, with instructions to examine into the figures both before and since the War, and to proceed with its investigations on the spot without delay, on the clear understanding, which shall be accepted by both parties—namely, by Turkey and by Greece-

'(a) That they will accept the results of such arbitration;

\footnotetext{
${ }^{2}$ See Chapters V. and VI.

${ }^{1}$ The Angora delegates were nominally received as members of the Constantinople Delegation, in order to save the dignity of the Allied statesmen whose treaty of peace they were defying. The Constantinople delegates solved the problem by entrusting the presentation of their case to Bekir Samy Bey, the chief representative of Angora.
} 
(b) That the remaining clauses of the Treaty of Sèvres

shall remain unaltered, and shall be loyally accepted both by Turkey and Greece.'2

Had the Supreme Council instituted such an investigation two years earlier, before sending the Greek troops to Smyrna, the facts which would have come to light might have impressed them sufficiently to enable them to resist the temptations of opportunism. But they had left undone those things which they ought to have done and done those things which they ought not to have done, and there was no health in their diplomacy. The Turkish delegation, through its spokesman Bekir Samy Bey, did indeed accept the proposal, with certain stipulations as to the conditions of investigation and reservations in regard to the remainder of the Sèvres Treaty; but the Greek representative, Mr.

Kaloyerópoulos, replied that he had 'instructions from the Greek National Assembly to base himself on the Treaty of Sèvres.' 'Physician, heal thyself!' No doubt the Greek Foreign Minister divined that the identical formula presented by the Allied Governments concealed a divergence of view. Did Mr. Lloyd George really desire a recount of the population in the disputed districts, based this time not on the collation of interested estimates but on a genuine inquiry? ${ }^{1}$ The acceptance of the proposal by the Turks showed that, at least in their belief, such an inquiry might prove damaging to the 'Lloyd George policy.' In rejecting it,

\footnotetext{
${ }^{2}$ Quoted from the official communique published in the Times of the $26^{\text {th }}$ February 1921.

${ }^{1}$ For the statistics on which the Supreme Council justified the dispositions of the Treaty of Sèvres in regard to the Smyrna Zone, see Chapter IV., p. 133.
} 
therefore, the Greeks might not incur the displeasure of at least one of the parties that had put it forward, and with a calculated temerity they refused to abandon by negotiations what they still hoped to hold by force.

After this first rebuff, an alternative proposal of a very different character was submitted by the Allied Governments on the $12^{\text {th }}$ March. The document ${ }^{2}$ consisted of a series of proposed modifications of the Treaty of Sèvres. Concessions were offered to Turkey in regard to her admission to the League of Nations, her contingent expulsion from Constantinople, ${ }^{3}$ the chairmanship of the Straits Commission, the scheme for judicial reform, the strength of the Turkish Army, the area of the zone of the Straits, the military status of Constantinople, the size of the Turkish Navy, foreign financial and economic control, and the admission of residents in Turkey to the privileges reserved for nationals of the Allied Powers. There were also territorial concessions. In regard to Kurdistan, the Allies 'would be prepared to consider a modification of the Treaty in ${ }^{1}$ a sense in conformity with the existing facts of the situation.' In regard to Armenia, the stipulations of the Treaty ${ }^{2}$ 'might be adapted on condition of Turkey recognizing the rights of Turkish Armenians to a national home on the eastern frontiers of Turkey-in-Asia.' But the crucial territorial proposals came at the end:-'In regard to Smyrna, the Allies would be ready to propose an equitable compromise with a view to ending the present

\footnotetext{
${ }^{2}$ Published in extensor in the Times of the $14^{\text {th }}$ March 1921.

${ }^{3}$ See Treaty of Sèvres, Article 36.

${ }^{1}$ Articles 62-64.
} 
unhappy state of hostilities and ensuring the return of peace.

'The region called the Vilayet of Smyrna would remain under Turkish sovereignty, a Greek force would remain in Smyrna town, but in the rest of the sanjak ${ }^{3}$ order would be maintained by a gendarmerie with Allied officers and recruited in proportion to the numbers and distribution of the population as reported by an InterAllied Commission. The same proportional arrangement, equally according to the report of the Commission, would apply to the administration.

'A Christian governor would be appointed by the League of Nations and assisted by an elective assembly and an elective council. The governor would be responsible for payments to the Turkish Government of annual sums expanding with the prosperity of the province.

'This arrangement would in five years be open to review on the demand of either party by the League of Nations.'

The terms of this second proposal proved that Mr. Kaloyerópoulos had shown good judgment in rejecting the first. The investigation originally proposed in Thrace had been dropped altogether, and in the district round Smyrna the proportion between the two national elements in the population, though it was still to be investigated, was only to tell in Turkey's favour within limits previously

\footnotetext{
${ }^{2}$ Articles 88-93.

${ }^{3}$ The zone provisionally assigned to Greece by the Treaty of Sèvres included the town of Aivali and the sanjak of Manysa as well as the sanjak of Smyrna.
} 
defined. Turkey was indeed assured on paper of the permanent maintenance of her sovereignty, but what was that assurance worth? Autonomy under a Christian governor, paying tribute and flying the Ottoman flag, called up in Turkish minds the precedents of Moldavia and Wallachia, Serbia and Bulgaria and Eastern Rumelia, Samos and Krete and the Lebanon. In all these cases, such arrangements had been pressed upon Turkey by the Western Powers with the solemn guarantee that they would go no further, and invariably they had resulted in the complete separation from the Ottoman Empire of the provinces so differentiated. In the new proposal in regard to Smyrna, they were to be reinforced by the presence of a foreign garrison. No doubt all this was interpreted by both the Turkish and the Greek delegations as a method of executing the Sèvres clauses in a more roundabout way; and if it were a choice between the two, the Turks would probably have preferred the less long-drawnout operation. According to their experience, the lesion involved in autonomy was equally certain to sever the province from Turkey in the long run, an the revival of this traditional diplomatic device was an indication-all the more insulting if unintentional—-that the Powers meant to keep the 'Sick Man' prostrate by applying the old-fashioned treatment. This proposal was therefore as unacceptable to the Turks as the former had been to the Greeks; and as it promised to promote the 'Lloyd George policy' by securing for the Greeks the substance of what they wanted, it seemed unlikely that it represented the real wishes of France and Italy, even though it had been put forward (like its predecessors) in the name of all three Powers. The Greeks, on their side, were 
not enthusiastic over it. It was, after all, a whittling down of their claims; without the consent of the Turks, it was valueless in practice; with a military offensive (to which they were looking forward with mistaken self-confidence ${ }^{1}$ ) seemed to them a more promising solution. Would it put them in the wrong? They ascertained that in 'forestalling an enemy attack' they ran little risk of incurring their backer's displeasure. ${ }^{1}$ So the Conference broke up; the delegates went their ways to lay the second proposal before their principals; but the latter never had to draft their refusals, for within less than a fortnight the Greek Army launched its ill-fated Spring offensive. Because of the rift in the counsels of the Allied Governments, Greek and Turkish soldiers killed each other to no purpose at the battle of In Önü.

On the $21^{\text {st }}$ June 1921 , four months after their first failure and on the even of a much larger Greek offensive, for which preparations had been going forward ever since the In Önü reverse, the Allied Governments attempted mediation again. After a consultation between Allied statesmen, the British Government telegraphed to the Greek Government in the name of the three Western Allied Powers, deprecating further military operations:

'They were prepared to attempt the task of conciliation if the Hellenic Government were disposed to place its interests in their hands. Should the Greek Government decide that

\footnotetext{
${ }^{1}$ See Cheaper VI.
} 
it was not prepared to accept outside intervention or advice, the Allied Powers could not persevere in an action that would obviously be fruitless. In such a case the responsibility for the consequences of [a] renewed struggle would rest upon the Greeks themselves. On the other hand, should the Hellenic Government decide in its own interests to accept the intervention of the Powers, the latter were prepared to state the terms upon which their assistance would be proffered, and, in the event of these being accepted, to approach the Turkish Government with a view to the immediate suspension of hostilities and to negotiations for the conclusion of peace. ${ }^{2}$

The Allied representatives duly 'proceeded to discuss the terms in question, and arrived at a general agreement as to the lines on which they would proceed,' but this belated second demarche on their part in the cause of peace was terminated by a prompt through courteous refusal from the Greek Government. The Powers were informed that 'the conduct and decisions of the Greek Government can be dictated by military considerations only. . . Any adjournment of the operations would compromise the situation to the disadvantage of Greek and the encouragement of enemy resistance. ${ }^{11}$ For three months Greece had been mobilizing her reservists and depreciating her currency

\footnotetext{
${ }^{1}$ Bekir Samy Bey also did business with the backers of Angora; but the agreements which he negotiated privately with the French and Italian Governments were repudiated by the Great National Assembly on his return.

${ }^{2}$ Quoted from a statement made on the $23^{\text {rd }}$ June 1921 , in the House of Commons, by Mr. Chamberlain in answer to a question by Major-General Sealy.
} 
in order to make her maximum military effort. On the eve of delivering the longprepared blow, the Greek Government could hardly be expected to submit the destinies of their country to a court in which they had good reason to believe that two out of the three judges were prejudiced against her; and in their reply they pertinently remarked that 'this situation ... is caused by the application of the penalties contained in the treaty with regard to the Near East. ${ }^{1}$ Neither they nor the Turks nor the Allies themselves were yet able to break the vicious circle into which the 'Lloyd George policy' had drawn them. Because the Allied Governments were no more unanimous and impartial in June 1921 than they had been in February, Greek and Turkish soldiers again killed each other fruitlesslyand this time in much larger numbers-at Kiutahia and Eski Shehir and on the Sakkaria in July, August, and September.

These attempts at peace-making really came to nothing because the Powers each still expected in their hearts to gain more by playing their pawns against each other than by stopping the game, while the pawns each believed and openly declared that, with such powerful players behind them, they had a sporting chance of checkmating their adversaries. Nothing struck me more forcibly during the eight months that I was in touch with the Greek Army and public, than the universal belief that Great Britain, or rather the Prime Minister wielding the resources of Great Britain, would see them through. It was the one point on which all Greeks-Ottoman subjects and Hellenic, literates and

\footnotetext{
${ }^{1}$ Quoted from the semi-official précis of the Greek Government's Note, issued at Athens on the $25^{\text {th }}$ June and published in the Times on the $27^{\text {th }}$ June 1921.
} 
illiterates, Royalists and Venizelists, civilians and soldiers, privates and generals-were in enthusiastic agreement. 'With Great Britain supporting us we are not afraid of anything.'-'But are you sure we are supporting you? Most English people aren't interested in Greece or the Eastern Question.'-'Well, Lloyd George is supporting us, and he will throw the resources of Great Britain into the scale if we can't do the job by ourselves.'-'But Mr. Lloyd George isn't an autocrat. He can only help you if public opinion lets Parliament vote him the men and money.'-'Oh! You will vote them. You know your own interests. You know how useful a Greater Greece can be to a naval Power like yours.'-'Yes, but it isn't worth our while to quarrel with our Allies, and you forget that we have recently made a joint declaration of neutrality!'-_Oh, we know all about British policy. We have watched you for years. We have seen you throw dust in people's eyes before. You will be with us all right when the moment comes. We aren't afraid. Here is to the health of a noble son of the great country which is the benefactress of Greece!' It was always the same conversation. I lost count of the number of times that I repeated my part; and the Turks on their side, as soon as I began to gain their confidence, used to express equal assurance in the support of Italy and France.

I feel certain from my own experience that the 'will to war' in both nations was sustained by nothing so much as by this belief that they had stronger Powers behind them, and that their ardour would have been damped and their claims moderated to the point of compromise, if once they had both been convinced that there would be no more Western backing for either party. In order 
to convince them some very emphatic demonstration of Anglo-French solidarity was necessary, for optimism in politics is their one common national characteristic, and they both enormously exaggerated the amount of support which they had been receiving or were likely to receive from one or other of the Allied Powers. Neither the Greeks nor the Turks realised the narrowness of the means allowed to the French and British Governments by their public for carrying out policies in the East, and hence they did not perceive that these backers of theirs value their services only in so far as they relieved them from making efforts themselves. They did not suspect how quickly pawns in distress become an embarrassment, or how little the players care if they disappear from the board. These Near and Middle Eastern nations are still inexperienced, and their backers have never undeceived them. Occasionally, indeed, they may actually have deluded them and led them on. In the autumn of 1921, for example, both belligerents were more inclined than they had previously been (and, above all, simultaneously inclined) towards peace. The Greek Army had made its supreme effort and had failed to deliver the knock-out blow; the Turkish Army had been shaken and had only just escaped destruction. The Greek 'will to war' was weakening and the Turkish had not yet begun to recover srength. ${ }^{1}$ Most encouraging symptom of all, the British Government were at last facing the facts and preparing a proposal for combined Allied mediation on the basis of an evacuation of Anatolia by Greece. But the favourable moment passed, and there

\footnotetext{
${ }^{1}$ See Chapter VI.
} 
is some evidence that the failure to seize the opportunity for negotiations was due to advice deliberately given by Paris to Angora. I came across such evidence myself, and a report to the same effect was made independently by the correspondent of the Times at Constantinople:

'I learn on good authority,' he telegraphed on the $5^{\text {th }}$ October, ${ }^{2}$ 'that the Porte has been informed by its delegate Nabi Bey, who recently has held several conversations with prominent French officials and politicians, that French political circles are not likely to consider favourably a Greek request for Allied mediation, should such be made in the near future. They believe it would be a false step for the Nationalists to demand or accept European intervention at the present juncture, and that [the] weariness of the Greek Army will finally compel Greece to accept European mediation on terms far more favourable to the Turks than it will now accept.'

The Times correspondent's information and my own is supported by the fact (which was not then public knowledge) that M. Franklin-Bouillon and Yusuf Kemal Bey were at that time actually engaged in negotiating a separate agreement between the French and the Nationalist Governments. But if our information was correct, Angora was very badly advised by its new Western friends. It was already evident that the campaign in Anatolia would be terminated

\footnotetext{
${ }^{2}$ Times, $10^{\text {th }}$ October 1921.
} 
either by mediation or by exhaustion, ${ }^{1}$ and that though the method of exhaustion would undoubtedly break the Greek 'will to war' first, the process might complete the devastation of the richest part of the Turkish national home. No government can afford to prolong a war which is being fought in its own country. Yusuf Kemal Bey would have done well to visit the devastated regions in France and ask himself whether the French victory in the fifth year of the European War was better for France than if she had made peace by negotiation two years earlier. Indeed, both belligerents, if they had recognised their true interests, would have made up their minds to enter into direct negotiations with one another rather than allow the Western Powers to exploit them any longer; and the Western Powers, on their side, would have taken common action to bring a settlement about. Our interest in stopping the Graceo-Turkish War was not so immediate as that of the combatants. Our countries were not being ravaged by it nor our currency sensibly depreciated nor our young men killed. Yet the continuance of this remote conflict was seriously affecting our own relations. So long as the Greeks and Turks (confirmed in their bellicose mood by our real or fancied encouragement) continued to fight each other, they each had the strongest incentive to make mischief between Great Britain and France, in order to make sure of retaining our respective backing. I think I never met a Greek who did not speak ill to me purposely of the French and Italians, and when the Turks forgot for a moment that I was English and spoke as they were in the habit

\footnotetext{
${ }^{1}$ See Chapter VI.
} 
of speaking to members of the other two Allied nations, they used the same language of my fellow-countrymen. During the battle of In Önü, ${ }^{1}$ I was continually told by Greek soldiers of every rank that French and Italian officers had been seen directing the fire of the Turkish artillery; and I afterwards saw a series of articles by Madame Gaulis, a French correspondent who was present at the same battle on the Turkish side, in which she reported stories told her by the Turks of unneutral and indeed atrocious behaviour by the British officers attached as observers to the Greek Army. Both stories, as I was in a position to know, were untrue, but both were genuinely believed and eagerly passed on by Greeks and Turks to Englishmen and Frenchmen respectively in order to make mischief between us.

When I accompanied the Ottoman Red Crescent Society's expeditions to evacuate the survivors of atrocities committed by the Greeks along the southeastern coasts of the Mamara, ${ }^{2}$ the Greek authorities more than once compromised British honour in an exceedingly unpleasant way by hoisting Red Ensigns side by side with the Greek flag over the scenes of their misdoings. The French and Italian flags were conspicuously absent, and the effect was not lost upon the Allied officers attached to the expedition, the Red Crescent representatives, and the terrorised Turkish population. At the headquarters of the Greek Tenth Division at Gemlik, I witnessed an amusing piece of unconscious counter-propaganda. Our three Allied officers had gone inside to

\footnotetext{
${ }^{1}$ See 'The Origin of a Legend,' p. 254.
} 
discuss procedure with the Greek Chief-of-Staff, leaving their three orderlies in the courtyard; and these Western soldiers, who had been working for several weeks together and were the best of friends, stood in a group of khaki, blue and grey-smoking, communicating by broken words and gestures, and laughing with evident good humour. The spectacle of this fraternisation between nations who ought to have been at loggerheads on their account was altogether too much for the Greek soldiers on duty. Could a man in English uniform really be on speaking terms with the common enemies of Greece and Great Britain? They could not keep their countenances. Some scowled from the upper windows; another-hit in the face by this appalling spectacle as he came suddenly round a corner-stopped dead with his jaw dropping, while the innocent causes of this consternation went on with their conversation in complete ignorance of the effect which they were producing. Yet at Gemlik, too, there were unpleasant features. In the summer of 1920 the Nationalists had originally been driven out and the town occupied by the British Navy co-operating with the Greek forces, ${ }^{1}$ and the building now used as Divisional Headquarters by the Greek General Commanding in the zone of the Greek atrocities, ${ }^{2}$ had formerly served as ours. Notices painted up in English were still visible on the walls; and in the neighbouring Turkish village of Ömer Bey, which was daily expecting to share the fate of the villages north of it, we were told that the British naval authorities, before they left, had arranged the surrender of arms. If the inhabitants had only

\footnotetext{
${ }^{2}$ See Chapter VII.

${ }^{1}$ See Chapter VI.

${ }^{2}$ See Chapter VII.
} 
known that a few weeks later the British were going to hand them over to the Greeks, they would have fought, they said, there and then rather than find themselves later, defenceless, at the mercy of their national enemy. There was plenty of material for mischief-making, and it was not neglected by either party.

Such perpetual propaganda on the part of all the members of the local nationalities with whom they have to do; undoubtedly does make mischief between local representatives of the Powers. They may be on their guard against it; they may make loyal efforts to feel and display mutual goodwill, but the constant suggestion accords with the tradition of Anglo-French rivalry which they have inherited from many generations of predecessors, and with the palpable divergence in the policy of their Governments which appears in the instructions which they are perpetually receiving from home. So the old Eastern feud between France and Great Britain is revived in situ, and is communicated to 'official circles' and to public opinion in Paris and London, where it is echoed in the Press, magnified by unsatisfactory conferences between the Prime Ministers, and re-communicated, in a more acute form, to the already infected embassies, consulates, schools, and missions where it started.

The Agreement between France and the Turkish Nationalist Government, signed at Angora on the $20^{\text {th }}$ October 1921, was a danger-signal. Its contents, with which a fair-minded British critic might have little fault to find, were not what mattered. It was all to the good that the campaign in Cilicia should come to an end; that France should abandon her economic zone in Anatolia; and that the principle of nationality should be applied more fairly than it had been under the 
Treaty of Sèvres in the borderland between Turkey and Syria, by the restoration of a strip of territory to the former. ${ }^{1}$ The strategic danger to Mesopotamia involved in the arrangements made by the French and the Nationalist Government about the Baghdad Railway is rather theoretical; and as for the Christian minorities in the abortive French zone, which France undertook to protect by the Tripartite Treaty of the $10^{\text {th }}$ August 1920 , it is evident that no situation could have put them in greater danger than the previous state of warfare, and that an understanding between Paris and Angora at least offered the possibility of securing them better conditions. In fact, an unprejudiced reader of the correspondence ${ }^{1}$ between the French and British Governments, which arose out of the Franklin-Bouillon Agreement, will probably concede that the Quai d'Orsay had the best of the argument on nearly every concrete question. But on the main issue the British Government were obviously in the right. A separate peace (and this was in reality a separate peace) between France and the Nationalists obstructed a general peace in the East and put a dangerous strain upon the Entente.

The damage done to the prospects of a general Near and Middle Eastern settlement was clear. Even if the French Government did not explicitly advise Angora to be unaccommodating, the conclusion of the separate agreement was bound to have an equivalent effect upon the Nationalists' minds. Bellingerency is

\footnotetext{
${ }^{1}$ There are certain Arab and Armenian minorities in the retroceded strip, but the great majority of the population is Turkish and Kurd.

${ }^{1}$ White Paper (Turkey No. 1 (1922)=Cod. 1570).
} 
a hysterical condition at the best, and when a belligerent finds its hands suddenly strengthened, it is hard for it to keep its head.

The strain imposed upon the Entente by this open rift between the two Governments in their Oriental policies at last aroused some alarm in the minds of the French and British public. There is no need here to point out the general issues at stake. The moment that the possibility of a breach in the Entente was faced, they became appallingly apparent. This book is only concerned with the particular catastrophe which such a breach would bring about in the relations between the Western and the non-Western worlds. The crisis upon which these relations have now entered has been discussed in Chapter I., and in this crisis Great Britain and France are joint trustees for Western civilisation. Between them they control, directly or indirectly, the greater part of the Middle Eastern world. Germany has forcibly been excluded from the advantages and responsibilities of representing our civilisation in the East. The Italian dominions in North Africa are an enclave, the Dutch dominions in the East Indies an outlying province. France and Great Britain, though they are far from embodying the total strength and wisdom of the West, have taken upon themselves the tremendous task of guiding West and East out of the paths of destruction. If they do their best and do it together, they may just succeed. If they fall out, failure is certain; and if they fail, they will not be forgiven ${ }^{1}$.

\footnotetext{
${ }^{1}$ It would be unfair to close this chapter without referring to the joint memorandum drawn up on the $22^{\text {nd }}$ March 1922 by the Foreign Ministers of France, Great Britain and Italy as a result of the five days' conference at Paris, and communicated by them to the Press (see Times of the $28^{\text {th }}$
} 
IV

\section{THE BACKGROUND IN ANATOLIA}

ON the $15^{\text {th }}$ May 1919, a destructive force was let loose in Western Anatolia, as sudden and apparently incomprehensible in its action as the eruption of a volcano. One morning, six months after the close of the European War, civilians and disarmed soldiers were massacred in the streets of Smyrna; whole quarters and villages were plundered; then the rich valleys in the hinterland were devastated by further arson and bloodshed, and a military front came into existence, which cut off the ports of Smyrna and Constantinople from the interior and ruined their trade. As the war continued, capital investments like houses, bridges, and tunnels (with which the country was already too poorly provided) were steadily destroyed, cattle lifted, crops commandeered, human beings conscripted, deported or otherwise driven away, if they escaped being murdered. In fact, a wholesale ruin of the country and extermination of its inhabitants began, over an area which extended with alarming speed. Within eight months the destruction that had started on the Smyrna quays was at work in Cilicia, at the

March 1922 for the text). In tone, even more than in substance, this document showed a welcome departure from the customary dictatorial style of the Supreme Council. Its authors frankly admitted the inability of the Western Powers in the actual circumstances to settle the Near and Middle East by force, and addressed themselves in courteous and conciliatory terms to the belligerents, supporting each proposal that they made by well-reasoned arguments. For the first time, they gave evidence of a genuine determination on the part of the Powers to act in unison and with impartiality. Lord Carson's account of the conference, in a speech delivered on the $30^{\text {th }}$ March 1922 in the House of Lords, confirmed and amplified the memorandum. The conference took place while this book was in the press, but by the time it was printed off, there were some indications that the change for the better in London, Paris and Rome was producing a corresponding change at Athens, Angora and Constantinople. While this development could not undo the facts set out in this chapter, it did (at the time of writing) give more ground for hope that the worst possibilities might be avoided. 
other end of Anatolia. Within eighteen months, it had overwhelmed the Armenian Republic of Erivan, beyond the north-eastern boundaries of Turkey-in-Asia.

Of course, volcanic action is not the isolated, supernatural phenomenon which it appears to be. The force discharged with such terrible consequences at a particular point has been accumulated there slowly by stresses and strains converging from all quarters; and if we look sufficiently far behind the date and beyond the place of the eruption to take into account all the factors, we find ourselves confronted by nothing outside the ordinary course of nature. So it is with the war-after-the-war in Anatolia. We cannot understand it if we begin our investigation with the landing of the Greek troops in May 1919, for that was only a symptom of the deeper disturbances discussed in the foregoing chapters. The break-down of Near and of Middle Eastern civilisation, the introduction of the Western idea of political nationality, the traditional rivalries of the Powers and the attraction of Greece and Turkey into the vicious circle, remote though they may have seemed, are the necessary prologue to the Anatolian drama. This prologue is not complete without some description of the doomed region and its people, as they were before the smoke and the flames and the burning streams of lava overwhelmed them.

The earliest relevant point in the historical background is that Anatolia was one assimilated by Ancient Hellenic civilisation. The propagation there of the Ancient Greek language and of the city-state went on through the whole course of Graeco-Roman history. In the twelfth century B.C. the first Greek colonies were planted on the western littoral. The sixth century after Christ saw the final 
extinction of the pre-Greek languages in the interior. This process belongs to a closed chapter. None of the civilisations now in contact in Anatolia were yet in existence. It has to be mentioned here partly because of the romantic appropriation of the Ancient Hellenic past by the Modern Greeks, and partly for its bearing on the next point.

This second point is that Anatolia did not cease to be Greek during the interregnun (about A.D. 375-675) between the submergence of the Ancient Hellenic and the emergence of the Modern Western and Near Eastern civilisations. Before its break-down the Ancient civilisation had retired from its broad eastern domains into a citadel, Constantinople, flanked by two glacis, the Balkan and Anatolian Peninsulas; and finding itself too weak to hold both outworks, the beleaguered society chose to concentrate its defensive efforts on the Anatolian frontier. The Balkan Peninsula was abandoned to be overrun by nomads and Slavs. For several centuries Salonika was continuously blockaded by the barbarians. Even the Peloponnese, the heart of the Ancient Greek world, was largely occupied by Slavonic settlers, who were only afterwards assimilated by the Modern Greeks through being converted to the new Near Eastern civilisation. In Anatolia, on the other hand, the barbarians never gained a foothold, and there was therefore a gradual transition from the old civilisation to the young one. Ancient Greek ceased to be a living language and was replaced by Modern Greek in the mouths of the people. But Ancient Greek remained the language of literature (like Latin in the West) and the affiliations of the vulgar tongue were not obscured or forgotten. In Anatolia the Modern Greek constituent 
of Near Eastern civilisation was evolved out of the Ancient Greek constituent of the preceding Graeco-Roman culture.

Anatolia, in fact-and this is the third point—was the cradle of the Near Eastern civilisation which was growing up from the eighth to the eleventh century after Christ. In the 'East Roman Empire' (the leading state in the early Near Eastern world) the dynasties, the nobility, and the territorial army were recruited from Anatolia, and the Anatolian provinces (which officially included the regions now called 'Western and Eastern Thrace') ranked above the European. Constantinople the capital was the 'bridgehead' of the Empire in Europe (to quote the phrase of a distinguished Byzantine scholar). Like Ottoman Constantinople, it took and did not give. The Imperial enclaves in European Greece only forwarded their surplus revenues to the Treasury after defraying their own expenses. The Anatolian revenues, on the other hand, were paid directly to, and the Anatolian troops and officials remunerated directly from, the centre. Anatolia was at once the cradle of Near Eastern civilisation, the birthplace of the Modern Greek people, and the backbone of the mediaeval Greek state. From this source a new culture radiated among the Bulgars, Jugoslavs and Rumans, the Ukrainians and Russians, and the peoples of the Caucasus.

The fourth relevant point in the history of Anatolia is its relation to that premature break-down of Near Eastern civilisation which has been discussed in Chapter 1. East-Central Anatolia was the first part of the East Roman Empire to be touched by decay. The strain of the Hundred Years' War (A.D. 913-1019) between the Greek and Bulgarian states weakened the East Roman 
Government's control over these distant but vital provinces. The local officials and commanders turned into a feudal nobility, which encroached on the lands and liberties of the peasantry. From the first years of the Bulgarian War there were agrarian troubles here, with which the Government failed to deal effectively. In fact, the Government itself began to fall under the landlords' control. During the breathing-spaces in the Bulgarian War, the military efforts of the Empire were wantonly kept at a stretch to conquer fresh territories for feudalism on the eastern border. ${ }^{1}$ After exercising this fatal influence on state policy, feudal anarchy finally prevailed over state authority in the Near East about the time when Western Governments-the Normans in England and Sicily and the Capetians in France-were organising Western feudalism into a system serviceable to the state's activities. Thus, a superficial and temporary extension of the East Roman Power in the Balkan Peninsula and the fringes of the Middle East was accompanied by a serious internal break-down of Near Eastern society in EastCentral Anatolia, which was tested almost immediately by the inroads of the Saljuq Turks from Central Asia (1064-75). After raiding not only the new provinces but the whole of Anatolia up to Smyrna and Isnik, the Saljuqs remained in permanent occupation of the East and Centre, and Turcified it.

This process of Turcification in East-Central Anatolia is one of the puzzles of history. Four centuries earlier the Constantinople Government, then

\footnotetext{
${ }^{1}$ The Arab Marches of Malaria were conquered between 920 and 942; Cilicia and Northern Syria between 962 and 976 (this by feudal usurpers on the Imperial throne); and Basil II., the slayer of
} 
apparently far weaker and undoubtedly less civilised than it was in the eleventh century, had succeeded in repelling the invasions of a formidable civilised Power-the Arab Empire in its prime. But now the sedentary, civilised population of East-Central Anatolia was assimilated by a barbarous nomadic people, driven out of its native environment on the steppes by some periodic variation of climate. The Saljuqs had not even numbers on their side. The Greek population which they found in the country must have been comparatively dense, while the contemporary records, as well as our general knowledge of nomadic social conditions, indicate that the invaders' numbers were small. The usual importance of numbers in deciding the issue when two peoples mix is illustrated in the almost simultaneous conquest of England by the Normans. Here everything but numbers was on the invaders' side. They were superior in culture, politics, and military technique, and they kept up a close connection with their kinsmen on the Continent. But their numerical inferiority outweighed all these advantages, and eventually they were assimilated by the backward population which they had conquered. How, then, did the Greeks fail to assimilate the Saljuqs though they had numbers as well as civilisation in their favour?

The radical change in language and nationality which occurred in EastCentral Anatolia after the eleventh century of our era, really has no parallel in Western history. Since the close of the Dark Age, the changes in the distribution of nationalities in Western Europe have been singularly small. The linguistic frontiers between French and Flemish or French and High German have hardly 
varied, and even on our eastern borders, the encroachments of Germans on Poles, or of Poles on Ukrainians, have been sporadic. They have produced enclaves and minorities, not homogeneous transformations of population. The Germanisation of the greater part of Silesia has been something exceptional. The openness of the country towards the North German plain, the decimation of the Polish population by a Mongol raid in the thirteenth century, the presence of coal and iron and the consequent influx of German industrial workers during the past century, and the political union of Silesia from an early date with non-Polish countries, were a strong combination of special causes. Yet in spite of all this, the Polish nationality has retained sufficient footing in Silesia to produce one of the most difficult problems of national demarcation in the settlement after the European War. The case of Bohemia is more characteristic. Here, two streams of German colonisation almost encircled an originally less civilised Slav population; the first German university east of the Rhine was founded at Prag; the Kingdom was nearly always connected politically with German territories and was at last subjected continuously to Austria. Yet the German colonists have never pushed far out from the mountain-rim of Bohemia into the central plain, ${ }^{1}$ and in the end the Tchechs, assisted by the physiography of their country and by the fortunes of war, have established a political ascendency over the German immigrants. In Ireland, again, the rapid spread of the English language, since the introduction of national primary education between 1833 and 1845 and the great

annexation of Armenian principalities (A.D. 999-1046).

${ }^{1}$ That is, the agricultural colonists-for in districts where the rural population remained Theca, there was a Germanizing tendency, of varying strength and duration, in the towns. 
emigrations to America, has been only a linguistic phenomenon. It has been accompanied by no change of religion, and the separate national consciousness has been heightened, not diminished.

The change in East-Central Anatolia was of quite another order. Here, a military occupation in weak force by nomads was followed by the almost total extinction of Near Eastern civilisation, Orthodox Christianity and the Greek language and this was not accomplished by massacre. There is no contemporary evidence that the Saljuqs killed off the inhabitants they found and repeopled the country with their own stock, and the physical type of the modern population forbids any such hypothesis. The Central Asian 'Mongoloid' type is found in Anatolia, but it is rare, and the great mass of the Turksih-speaking peasantry are 'Alpines,' with a marked tendency towards the 'Armenoid' type which is already portrayed in representations of Hittites on Egyptian bas-reliefs of the fourteenth and thirteenth centuries B.C. The mediaeval Greek population was not exterminated by the Saljuqs but converted. As they had once turned from Hittites and Phrygians into Greeks, so they turned again from Greeks into Turks, under the influence of a few nomad intruders. This is the fact to be explained, and as analogies seem to show that the Saljuq conquest in itself was an insufficient cause, we must seek an explanation in the local developments that preceded it.

We must infer that, by the time of the conquest, the feudal anarchy in East-Central Anatolia had alienated the peasantry from their lords, and that education and the mental life which maintains the distinctive character of a 
civilisation were confined to a handful of lay and ecclesiastical landowners. Near Eastern civilisation here, in spite of an imposing exterior, must have become a hollow crust which broke under the nomads' horse-hoofs. The submerged peasantry profited by the break-down, and loved their old masters so little that in shaking off their yoke they did not hesitate also to discard their culture, in which the peasant had had only a nominal share. In fact, in the eleventh century A.C. the Anatolian peasantry, in contrast to the ruling class, may have been a more or less uncultivated people like the nomadic invaders and ready, like them, to adopt any way of life which offered them a better future. The Orthodox Church was bound up with the old oppression. Islam was untried and was attractively equalitarian in its professions. Saljuq nomads and Anatolian peasantry were amalgamated by their common conversion, ${ }^{1}$ and the nomad element was absorbed. In fact, the Saljuqs were not the cause but simply the instrument by which the peasantry of East-Central Anatolia were transferred from one civilisation to another.

This early Turcification of East-Central Anatolia was a separate event from that of the West and North-West, which did not begin till two hundred years later. Here there was more urban life and perhaps more rural liberty; the first Saljuq

\footnotetext{
${ }^{1}$ The traditional date for the conversion of Saljuq, the eponym of the Saljuq Turks, is A.D. 956 (Sir T.W. Arnold, The Preaching of Islam, $2^{\text {nd }}$ ed., London, 1913, Constable). But though many nomadic peoples (e.g. the modern Kirghiz Kazaks) have been nominal Moslems, Islamic institutions do not generally get hold of nomadic peoples unless or until they settle down. Probably most of the eleventh-century invaders of Anatolia were still Shamanisms in practice, and the second swarm driven westwards in the thirteenth century were certainly so. There is some evidence that even Ertoghrul, the father of Osman, was a pagan (H.A. Gibbons, Foundation of the Ottoman Empire, Oxford, 1916, Clarendon Press).
} 
raiders were driven out again within twenty years, and Greek nationality and civilisation had a new lease of life. The causes of Turcification in this region, where it only began in the latter part of the thirteenth century, are also easier to analyse. In one respect history repeated itself, for another exhausting struggle in Europe-this time against the Western conquerors who came on the Fourth Crusade-loosened the hold of the East Roman Empire upon its remaining Asiatic territories. North-Western Anatolia was occupied by fresh parties of Turks while the Greeks were recovering Constantinople and the Morea; and the vanguard of these Turks (including the party led by Ertoghrul the father of Osman) were again Central Asian nomads, flying now not only from a drought ${ }^{2}$ but from the Mongols. In most other ways, however, the situation was different from that of the eleventh century. The new nomad immigrants in the North-West had behind them, in the Saljuqs of East-Central Anatolia, a population of their own language from which valuable reinforcements could be drawn, and these settled Turcified Anatolians, like the other sedentary Islamic peoples, were beginning to build up a new Middle Eastern civilisation. The main features of it have been discussed in Chapter I. From approximately A.D. 1300 onwards, it became a more attractive form of life than the prematurely overstrained and now moribund civilisation of the Near East. It offered not only a refuge for the

\footnotetext{
${ }^{2}$ The historical evidence afforded by recorded dates of the eruptions of nomads from the steppes into China, Russia, the Near and Middle East, and India, indicates a 600-year cycle of alternating dry and moist periods. The two Turkish invasions of Anatolia both fall within the dry period, A.D. 950-1250. It is not an accident that that period almost coincides with the interregnum (circa A.D.
} 
oppressed but a more promising career for the able and the ambitious, and the young Osmanli Power (as well as the neighbouring Turkish principalities which it subsequently conquered) was largely built up by renegade Greek nobles and officials. The classical instance of this is the family of Evrenós, the fortunes of which were made by the last Greek governor of Brusa. He surrendered the city to the Osmanlis after a long defence, when at last he despaired of help from the East Roman Government, and then turned Turk—carrying over with him, it seems, many of the notables and other inhabitants. ${ }^{1}$ Two generations later, a descendant of his conquered Macedonia for the Ottoman Empire and led the first Osmanli expedition into the Morea. For these services the family was invested with a fief at Yenije Vardar, which was still in their hands at the beginning of the nineteenth century. This assimilation by young Middle Eastern communities of the best energies that remained in the Near Eastern world was no doubt assisted by the Near Easterners' hatred of their mediaeval Western conquerors. ${ }^{1}$ The Ottoman conquests in South-Eastern Europe down to the close of the fifteenth century (a continuation of the movement that substituted the Turkish for the Greek nationality in Western Anatolia) were largely made at the expense of French and Italian rulers. But while in Europe the Osmanlis were the sole agents of Middle Eastern expansion, Western Anatolia was mostly Turcified by other new Turkish Powers, like the principalities of Sarukhan and Aidin in the valleys of the Hermus and the Maeander. Thus, in two distinct stages, all Anatolia was

975-1275) between the Ancient and the Modern civilisations of the Middle East. (For these climatic cycles see also Chapter VIII.)

${ }^{1}$ See H.A. Gibbons, Foundation of the Ottoman Empire, p. 48. 
appropriated by Turkish-speaking Moslem communities belonging to the new Middle Eastern world.

The next point of importance in the history of Anatolia is the unification of the separate Turkish states, of which there were forty or more in existence at the beginning of the fourteenth century. The Osmanli state, grown strong by acquisitions in Europe, turned round upon its Turkish neighbours eastward, and, in spite of the diversion made in their favour by Timur Lenk, they were all conquered and annexed before the end of the fifteenth century. Thus Anatolia again became a political unit after being partitioned and fought over for 400 years, only the predominant nationality was no longer Greek but Turkish. By the date A.D. 1500, Turcification had perhaps proceeded about as far as Hellenisation had when Ancient Anatolia was united under the Roman Empire, and it looked as if, in the modern case, political unification would again carry the linguistic and cultural process to completion. Certainly, during the succeeding centuries of Ottoman dominion, the Greek impress was more and more effaced and a Turkish impress substituted upon the plastic features of the Anatolian people, but in the end the parallel has not worked out. Of course the process was impeded by an obstacle which did not exist in the earlier age, when Greeks were made out of Phrygians and Lydians. A Modern Greek who turned Turk had not only to change his language and ways of life, but to get over the difference between two mutually exclusive religions, and this barrier would check assimilation except when mass-conversions were brought about by some special

\footnotetext{
${ }^{1}$ See Chapter I.
} 
inducement or pressure. Yet the Turkish language did in time become the vernacular of most of the unconverted Christian minorities that remained in Anatolia; and in Syria, under more or less parallel conditions, the barrier between the two rival universal religions has largely been broken down.

In Syria, where a Christian Syriac-speaking population was conquered in the seventh century after Christ by Moslem Arabs, the majority of the population was ultimately converted to Islam (as, in the later case, the majority of the Anatolians were), and the Christian remnant took to an Arabic (as in Anatolia it mostly took to a Turkish) vernacular. But in Syria there also survived or grew up a certain community of feeling between these Arabic-speaking Christians on the one side and the converted majority, with its infusion of genuine Arab immigrants, on the other. The early Arabic literature and culture were to some extent adaptations of Graeco-Roman originals, for which the Christian Syrians were the intermediaries. Arabic literature was thus not an exclusively Islamic affair, and there were Christians even among its distinguished men of letters. This created a common inheritance in which all speakers of Arabic, whether Christians or Moslems, could take pride, and in recent years, since Syria began to be affected by the Western idea of political nationality, some sections of the Christian minority have thrown in their lot with their Moslem fellow-countrymen. It may be 
a mistake to build too much upon the possibilities of co-operation between them, but undoubtedly the tendency is there. ${ }^{1}$

Nationalism has reacted quite differently upon the Turkish-speaking Christians in Anatolia, as has been demonstrated by their action during the European War. On the Palestine front, where Orthodox ${ }^{1}$ Christian Arabicspeaking Syrians were serving side by side with Moslem Syrians under Prince Feisal in order to liberate their common country from the foreign rule of the Turks, there were also Turkish-speaking Gregorian Christians from Anatolia who had enlisted in the French Légion d'Orient to fight on the anti-Turkish side, though they came from the same country as the Turks and used their language. Both these contingents of Christian soldiers were equally right or wrong in doing what they did. Both were technically rebels against their lawful sovereign. Both were probably justified by their previous treatment at the hands of the Ottoman Government, and certainly by the current Western doctrine of nationality. The interesting difference is that the Syrian Christians felt themselves to be of the same nationality as the Moslems with whom they shared their language and their country, while the Anatolian Christians regarded the Anatolian Moslems as foreign oppressors and found their national ideal in union with their Armenianspeaking co-religionists in Transcaucasia. One obvious reason for this difference

\footnotetext{
${ }^{1}$ Since the armistice, a parallel tendency has shown itself among the Christian Copts in Egypt to make common cause with the Moslem Nationalists against the British ascendency.

${ }^{1}$ The attitude of the Catholic Christian Arabic-speaking Syrians is more obscure, but there is reason to doubt the official French view that they feel themselves a separate nation from other Syrians and want an entirely independent state of their own.
} 
is that the Turkish-speaking Moslem majority in Anatolia, being the ruling nation in the Ottoman Empire, were able to oppress the local Christian minority, while in Syria the Moslem majority and the Christian minority were both under Turkish domination. But there is another reason of at least as great importance, namely, that, whereas there is no national community outside Syria and Egypt to which the Syrian Orthodox and the Copts respectively could feel that they belonged, the Turkish-speaking Gregorians of Anatolia have the Transcaucasian Armenians to look to and the Turkish-speaking Orthodox the European Greeks.

Before discussing the phenomena of nationalism produced in Anatolia by these special conditions, it is worth noting exactly how far the process of amalgamation between the different races, languages, and religions there has gone. There is a great variety of physical type in Anatolia. The basic 'Alpine' stock is crossed with 'Mediterranean' on the coast and with 'Mongoloid' and 'Nordic' (the latter in surprisingly large proportions) in the interior. But it is impossible to identify the source and date of introduction to these various strains, for they now crop up indiscriminately among members of all religions. 'Mediterranean' and 'Nordic' Moslems, 'Alpine' Orthodox and 'Mediterranean' Gregorians can be noted almost everywhere by the passing traveller.

There has been at least as much intermixture and interchange in language.$^{1}$ Among the Orthodox Christian minority in the extreme north-east ('Pontus'), colloquial Greek has survived continuously since the time before the

\footnotetext{
${ }^{1}$ See R. M. Dawkins, Modern Greek in Asia Minor (Cambridge, 1916, University Press).
} 
Saljuq invasion. In some groups of Orthodox villages between the Kyzyl Yrmak and the Cilician Highlands ('Cappadocia'), the spoken language is at present in transition from Greek to Turkish. The Gregorian Christian Highlanders, as well as the Orthodox element in the central vilayet of Konia (the former Turkish principality of Karaman), have almost entirely taken to Turkish in place of their respective Armenian and Greek mother-tongues. ${ }^{2}$ Eighty or ninety years ago, when the American Evangelical Missions started work in the interior, one of their first steps was to publish Turkish translations of the Bible in Greek and Armenian characters, to serve the needs of the local Christian communities. This combination of a borrowed vernacular and an inherited script has become characteristic of the Anatolian Christian minorities. At the village of Gölde, north of Kula, in the interior of the Aidin vilayet, I have seen such Turkish-Greek inscriptions on the tombstones in the churchyard, and mustered up all the Turkish I knew to talk to the 'bekji' (Turkish for 'guard') who was attending mean Orthodox Christian with 'Nordic' hair and eyes and nothing but Turkish on his tongue. Even at Kirkinje, an Orthodox village in the hills above Ephesus, a few miles from the coast and a few hours by train from Smyrna, the boys are only just learning Greek at school and the men have still to talk Turkish at home to their wives, who show no signs of becoming bilingual. At Adalia, on the south coast, I have heard that at one time in the latter part of the nineteenth century the Christians were speaking Turkish and the Moslems Greek—the Christian being

\footnotetext{
${ }^{2}$ Greek is still spoken in one or two Karamanly villages like Sill.
} 
the Turcified indigenous population and the Moslems refugees from Krete, where Greek is the universal language of both denominations.

From these influences of language and neighbourhood certain social results have followed. The Turkish-speaking Karamanly Christians who settled in Constantinople as small shopkeepers (often in Moslem quarters) certainly feel themselves different from the Greek-speaking Christian natives of Rumelia and the Kingdom of Greece. They are pleased if you talk to them in Turkish, and proud of their home and name. They do not appear to become assimilated to their Greek-speaking co-religionists, unless or until they make their fortunes and so mix socially with the leaders of the 'Millet-i-Rum'1 in the capital. There are also positive personal links created by mutual economic services, which have often given rise to hereditary friendships between Moslem and Christian families. But unhappily many of these links have been broken by the events of the last few years, and such good feeling has always been personal rather than corporate. If anything like a common national consciousness had grown up in Anatolia before the War, the Turkish-speaking Gregorian Christians of Cilicia would not have served in the French Légion d'Orient nor the Orthodox Christians of the Aegean and Marmara littoral have given assistance to the British Navy. Nationality is a question of sentiment, not of language or race, and in sentiment these Christian minorities have undoubtedly been anti-Turk. Without facing the inherent

\footnotetext{
${ }^{1}$ The autonomous organisation of the non-Bulgarian Orthodox Christians of Turkey for ecclesiastical and educational affairs and questions of 'personal statute' (e.g. registration,
} 
geographical, economic, and administrative difficulties, they have aspired to break their political connection with Turkey and to become citizens respectively to a Greek and an Armenian national state, and they have staked their lives and property on the slenderest expectations of realising this ambition. It has been a remarkable triumph of emotion over interest among people who set a high value upon material prosperity, and of the Western idea of political nationality in the most unsuitable environment. This deserves investigation, and, leaving the Armenian case aside, we have now to review the rise of Greek nationalism in Anatolia as a feature in the process of Westernisation.

The key to the present situation is the revulsion of feeling among the Near Eastern peoples towards the West which occurred in the latter part of the seventeenth century an has been discussed in Chapter I.; but it was about a century before this movement perceptibly affected the relations between Christians and Moslems in Anatolia. Then, in the last quarter of the eighteenth century, a Modern Greek revival began there, under Western influences, which bears resemblance in many points to the ancient process of Hellenisation.

The Modern movement started, like the Ancient, with colonisation, the best example of which is the settlement of Aivali. ${ }^{1}$ Here an obscure little Christian village rose to eminence in the space of a few years, apparently through the accident that a priest born and bred there subsequently gained

marriage, inheritance), under the presidency of the Oecumenical Patriarch (who, as the recognised head of this organisation, is an official of the Ottoman Government).

${ }^{1}$ See G. Sackers, Astoria ton Kydhonión (Athens, 1920, Vitsikunákis). 'Aivali' is the vernacular Greek name, being an adaptation of the Turkish 'Aivalyk,' but the purists have translated this into 'Kydhoniés' (which means 'Quince Orchard' in Greek, as 'Aivalyk' does in Turkish). 
favour in 'official circles' at Constantinople. About the year 1773 (in reward for services about which many legends have grown up) he obtained a firman from the Sultan granting his native place the privilege that no Moslem should thenceforth reside within the communal boundaries, and conferring considerable rights of self-government. This was the first opportunity given to the Modern Greeks for territorial self-government, ${ }^{1}$ and the extent to which the Western notion of political nationality was already in the air is indicated by the eagerness with which they took advantage of it. Though the territory was tiny and not particularly fertile, there was an influx of Greek colonists from other parts of the Ottoman Empire, especially from the Aegean Islands and the Morea, which has left its record in the predominance of the 'Mediterranean' type among the present population. The rocky soil was turned to account for the intensive cultivation of olives, and economic links with the West were formed by the exportation of oil and soap. At the outbreak of the Greek Revolution (1821), there were about 30,000 Greeks in Aivali and its dependent villages; 40 oil-mills, 30 soap-works; 2 hospitals; and an academy. ${ }^{2}$ This colony has survived the two catastrophes of 1821 and 1917.

There has also been colonisation inland, especially along the trade-routes radiating from Smyrna. The Greeks have incidentally benefited by the extension of the commercial hinterland of Smyrna, which has been going on ever since the

\footnotetext{
${ }^{1}$ They already enjoyed a somewhat precarious 'cultural autonomy' all over the Ottoman Empire, under the institutions of the 'Millet-i-Rum' (see above).

${ }^{2}$ George Finaly, History of Greece, vol. vii. pp. 179-80 (Oxford, 1877, Clarendon Press).
} 
sixteenth century, when the modern communities of Western merchants started business in the city. Western enterprise has enabled an increasing population to make a livelihood in Smyrna, and the newcomers have largely been Greeks, starting generally as clerks or shopkeepers and rising in many cases to be merchants on the Western scale. Since the building of the French and British railways in the hinterland after the Crimean War, the immigration of Greeks has been especially noticeable. ${ }^{1}$ They have settled along the lines as railwaymen, as agents of Smyrna firms, as local traders and shopkeepers, and have shown a tendency to invest their profits in land. Estates that have passed into the hands of Greek landlords have naturally attracted Greek labourers, particularly for specialized forms of production, like olive or currant-farming, in which the peasantry of European Greece and the islands is skilled.

At Kula, about half the Christian element in the mixed population of the town are Turcified descendants of the original mediaeval Greek inhabitants, but the other half are recent immigrants from Samos and other islands. At Aidin, before the catastrophe of 1919, there was a recently-built Greek quarter inhabited by about 12,000 shopkeepers, merchants, workmen, manufacturers, professional men, and landowners, and there were similar settlements on a less ambitious scale at smaller inland centres like Salyhly. At Bergama, every Greek as well as every Turkish householder possesses land, on which he lives and

\footnotetext{
${ }^{1}$ This has been partly due also to the incipient Westernisation of the Ottoman Empire, for railways could not be built till the Central Government had re-established security in the provinces
} 
works at certain seasons, even if this is not his staple economic occupation. At Kinik and other places in the Kaikos valley east of Bergama, there are now several purely agricultural Greek villages.

This colonisation has been accompanied by a revival of the Greek language among the Turcified native Christians. A Greek officer who had just visited the town of Nazylly up the valley of the Maeander, told me in the winter of 1921 that one of the Christian notables there, after showing great distress at not being able to communicate with him in the national tongue, finally put his hand on his heart and said to the interpreter in Turkish: 'Tell him that though my tongue is Turkish my heart is Greek.' Many of this notable's more studious co-religionists have already taught their tongues the language of their hearts, and in this they have been helped by the immigrants, who have not only brought their language with them but have founded schools. As soon as their olive plantations began to bear fruit, the Aivaliots were no longer content with primary education. Their celebrated Academy was started, with the Ottoman Government's permission, in the years 1800-3; and the Evanyelikì Skholì at Smyrna—founded in 1708, refounded in 1733, reorganized and recognised by the Ottoman Government in 1810 , and again in 1828 - has a longer history. The prominence of the schools and the number of the teachers are the most striking feature of Kirkinje, and zeal for education has gone hand in hand with economic prosperity. Since the beginning of the present century the revival of the Greek language, through 
schools largely staffed and supported from the Kingdom, has started among the distant Christian minorities in Karaman and Cappadocia.

The mainspring of the Greek revival in Anatolia is that instinct for corporate life on a small scale which was the soul of the earlier revival in Rumili and the Morea. The communal patriotism which one finds among the Anatolian Greeks to-day constantly reminds one of travellers' descriptions of Ýdhra, Pétses, Ghalaxídha, Ambelákia, and other European centres of Greek life a century ago. The mukhtar (head-man), the priest, the schoolmaster, the doctor, take a mutual interest in their respective duties and know how to work together. Voluntary subscriptions are forthcoming not only from merchants and landowners but from shopkeepers and labourers for the building and upkeep of church, school, and hospital, and for the salaries of clergy and teachers. At Bergama, where the Greek community were driven out in 1914 and spent six years in exile, they have burdened themselves, since repatriation, with an onerous loan in order to restart their secondary school, and have assigned the hospital building to it, because the former school building has been too much damaged for immediate repair. They have a genius for clubs. The 'Ladies Union' and 'Girls' Union' at Bergama have each made themselves responsible for particular pieces of reconstruction, and the re-opening of the Community Club was one of the first things done. In all these Greek communities the Boy Scout movement has been taken up and turned to account. In Anatolia the Greeks show an admirable faculty for making themselves at home in the wilderness and striking local roots. A shanty becomes a café, railway-platform an esplanade. No matter how 
unpromising the present, they have a radiant belief in the future of the place in which they have invested their energies. At Aidin I met a Greek doctor-a French subject belonging to a family of doctors educated in France from father to son-who had been on the point of retiring to France on his earnings when the catastrophe came. The Greek quarter was gutted, his house burnt to the ground, his safe broken open, his savings lost, and now he was starting out to rebuild his fortunes. His unshaken belief in the future of Aidin still gave his life the necessary savour of hope.

The political expression of this economic and cultural revival is a sense of unity with the Greeks of the Kingdom and a desire to turn the feeling into accomplished fact. In 1921 this political nationalism seemed to me strongest at Aivali, and there is less obstacle here than elsewhere to its realisation. The population is homogeneous and has hardly any intercourse with the Turkish hinterland beyond its olive-groves, while it is in constant communication by sea with Mitylini, Greece, Western Europe, and even America. The economic links with Greece are so strong that here alone, in the whole occupied area, the Greek currency had completely driven the Turkish out of circulation. In fact, in nationality and economic life Aivali is as much isolated from the rest of the Anatolian mainland as if it were an island, and it would not be impracticable to attach it to Greece as an enclave, somewhat as Zara has been separated from Dalmatia and attached to Italy.

At Smyrna, too, Greek national feeling is naturally strong. The Greek element in the city is far the largest aggregate of Greek population in Anatolia, 
and has the most frequent and direct communication with Athens. Many Smyrna Greeks are Hellenic subjects, either by immigration or by naturalisation. At the same time, the prosperity of the Greeks, like that of the entire business community, at Smyrna depends on maintaining and increasing the economic intercourse with the hinterland, and in this respect there could be no greater contrast than between Smyrna and Aivali. Smyrna is not a self-contained community, and you cannot stay there without being conscious every moment that the roots of its prosperity strike deep and far afield in the soil of Anatolia. You are also conscious that the Smyrniots are being torn in two between their national inclinations and their economic interests. They are in the same dilemma as the Germans of Danzig and the Italians of Fjume and Trieste-three Western commercial cities for which it has been particularly hard to devise a satisfactory settlement.

But the most difficult problem created by political nationalism is among the small scattered Greek communities in the interior. Here this Western novelty has been breaking the linguistic and economic ties between a minority and the majority on whose goodwill their livelihood if not their life depends, and has been giving them new ties of language and sentiment with Greece-a distant country hostile to the Ottoman Empire. They can only get political union with Greece in one of two ways: either emigration, which means exile if not ruin, or the annexation by Greece of the vast territories over which they are spread, and of the Moslem majorities among whom they live. The second solution is impossible (as is demonstrated by the history of the last three years), and attempts to realise 
it only drive the Turks into imposing the alternative in the drastic form of eviction or deportation. But if it were conceivable that Greece should annex all parts of Anatolia where Greek-feeling Orthodox Christians at the moment constituted over 25 per cent. (say) of the population, and if the rights and feelings of the subjected Turkish 75 per cent. were left out of account, even then the settlement would not be permanent. These Greek minorities may be regarded politically as rearguards of a retreating nation or as outposts of an advancing one, but they also have a positive economic reason for being in their present situation. A certain minority of Christian traders and artisans is at present the necessary complement to a certain majority of Anatolian Moslem peasants, and if this minority emigrated to Greece, or the Moslem majority in Anatolia gave place to a solid Greek population, their occupation would be gone, and they would have to find some other peasant-country, like Egypt or Russia, where they could earn their living as a scattered minority once more. Whatever national aspirations he may have, the Near Eastern petty trader is just as much bound to settle among backward cultivators as fishermen are to follow their shoals or the Labrador Indians their caribou.

For the Greek minorities in the interior, nationalism has been a will-o'-the wisp enticing them to destruction. Yet they, as well as the Smyrniots and Aivaliots, have been attracted by it, partly because the latent sense of insecurity, inherent in minorities, makes them susceptible to movements promising cohesion and backing, and blind to their inevitable dangers; partly, too, because of the romantic vein introduced into all modern nationalism through the special 
circumstances of its origin in the West. Owing to the virtual stability of our linguistic boundaries since the Dark Age (alluded to above), the romantic appeal to the past is a possible emotional basis in Western Europe for the demarcation of modern national states. Where Frenchmen or Italians held tournaments or built cathedrals in the Middle Ages, there are mostly still French and Italian populations anxious to be citizens of modern France and Italy. But in most parts of Anatolia where in the Middle Ages there were Orthodox Greeks belonging to the Near Eastern world, there are now Middle Eastern Moslem Turks. The continuity has been interrupted; the past offers not foundations but treacherous ruins; and the Greeks make matters worse by digging down below the mediaeval stratum to memories of Ancient Hellenism. For this folly we Westerners are largely to blame, for while we prudently refrain from importing the exploits of Ancient Romans, Gauls, or Goths into our contemporary national politics, and content ourselves with King Alfreds and Hohenstaufens and Joans of Arc, we have taught the unfortunate Greek peasant and merchant to say, parrot-wise, 'I am a descendant of Pericles,' like foolish parents who bring up their children to be more affected than themselves. In Anatolia this extravagance is unfortunately encouraged by perpetual suggestion. The country abounds in imposing remains of mediaeval and classical antiquity, and the very stones cry out to any one who is foolish enough to lend an ear. At Kula, certain fragments of sculpture dating respectively from about the sixth century B.C. and the second century after Christ, were pointed out to me as a serious argument for including the town in Greece in 1921. The offensive against Angora was going to 'cut the Gordian 
Knot'; the first day's advance inaugurated 'a new Catabasis of Alexander'; the official communiqué ran: 'We have occupied Dorylaion (Eski Shehir), ' the modern name being added in brackets for the benefit of readers who had not made a profound study of the classical geographers. Political romanticism is essentially unhistorical, being an attempt to telescope past and present into one another, and it has an unlimited capacity for ignoring what is inconvenient. At Gölde, the Christians were hyperconscious of the twelfth-century Byzantine church and of the Greek characters carved on the nineteenth-century tombstones, but took no account of the equally significant fact that the Greek script now recorded Turkish words. No doubt the Moslems of Gölde, when they go to school in imitation of their Greek neighbours, will claim the church as a monument of Saljuq art and argue that Turkish was the original language of the country, spoken by Lydians and Phrygians and Hittites before their temporary Hellenisation!

Turkish nationalism, indeed, is already in the field, and Anatolia has lately become its stronghold. But the Ottoman Turks have been about a century later than their Near Eastern neighbours in adopting this Western notion, and the Turks of Anatolia have taken to it last of all. In this as in other spheres of Westernisation, the Turks have only borrowed under pressure of necessity, and they felt the need for our political ideas considerably later than for our military and administrative methods. As the ruling race in the Ottoman Empire, they identified themselves with the state, like the German Austrians in the Hapsburg Monarchy, and, like them, they developed no separate national consciousness 
until the triumph of the subject nationalities forced them to put on the same armour in self-defence. The parallel holds in detail. In Austria, the German National Movement started among the German Styrians and Bohemians, who found themselves at grips with militantly nationalist Slav populations; and in the Ottoman Empire, the Turkish National Movement started among the Turkish minority threatened by Greek, Bulgarian, and Serb nationalism in Rumili. The Young Turk Movement first declared itself in the interior of Macedonia. Salonika was the home of the Committee of Union and Progress. It was not until the victories of the Balkan States in the war of 1912-13 had given a painful demonstration of what national enthusiasm and organisation can achieve, that the idea seems to have made any general impression on the Turkish people, and it was only then that the seeds of it were sown in Anatolia.

Up to that time the Anatolian Turks, like the Germans of Upper and Lower Austria, had been remote from the pressure of foreign ambitions, which had converged on Salonika and Constantinople. In their own country they were in an overwhelming majority, and the non-Turkish minorities (principally Circassians, Armenians, and Greeks) were learning to speak Turkish and giving little trouble. Their security was broken by the Greek conquest and annexation of the islands of Mitylini, Khios, and Samos lying a few miles off their coast, and their feelings were aroused by the arrival of thousands of destitute Moslem refugees from the lost provinces of Rumili. Hitherto they had drawn a distinction between their Orthodox Christian neighbours of the 'Millet-i-Rum' (i.e. Romyí, or 'East Romans') and the foreign Greeks in the hostile kingdom of 'Yunanistan.' But now 
the enemy was at their gates and the Rum were showing sympathy with him. Greek nationalism in Anatolia was felt by the Turks not only as a menace but as a betrayal, and the Christian minority was bound to suffer, just as the Italian minorities in Trentino, Trieste, Istria, Dalmatia, and other territories retained by the Hapsburg Monarchy after the wars of 1859 and 1866 were adversely affected by the liberation of their kinsmen in Lombardy and Venetia. In a Western monarchy like Austria, repression seldom went beyond the falsification of census returns and hostile discrimination in matters of government service or of state education. In the Near and Middle East, similar situations at present lead to spoliation and massacre.

Thus, before the Greek troops landed at Smyrna on the $15^{\text {th }}$ May 1919 , a Turkish as well as a Greek National Movement was already in existence in Anatolia, occasions for conflict had arisen, and conflicts had occurred. Apologists for the landing (or rather for the several statesmen who brought it about) will make the most of this fact, because it offers them their most plausible line of defence. They will argue that the landing cannot fairly be represented as the cause of the calamities that followed it, because these were the inevitable product of a previous situation and were bound to occur, whatever policy had prevailed at the Peace Conference in Paris. It may be doubted whether the defendants will appreciate this plea of impotence, for in statesmen it is a confession of bankruptcy. But as they may be driven to it, it requires examination. My personal belief is that, bad though the conditions of the previous ten years had been, the situation created in Anatolia by the armistice 
offered the Allied Governments, who then became responsible, a genuine opportunity for putting an end to the conflict and pouring oil into the wounds which it had made. I am convinced that after the armistice the unfortunate population of Anatolia might have been given a new start, and need not have been plunged, as it has been, into an internal war of extermination, which even those who consider it unavoidable will admit to be something far worse than the evils which the conflict between Greek and Turkish nationalism had produced in this country before. But just because I hold this view, I am bound to make all allowance for the other and to examine how far the breach had gone before the armistice was concluded.

One need not look back beyond 1908, for in Anatolia nowadays both Greeks and Turks testify to the comparative prosperity which they enjoyed before the Ottoman Revolution. 'Under Sultan Abdu'l-Hamid,' they have often said to me in almost identical words, 'we had little to complain of. We lived at peace with one another.' There is always something mythical about a 'Golden Age'memory, like glass, gets an iridescence by decay—but this myth contains something true. From the end of the Greek War of Independence down to the fall of Abdu'l-Hamid, there was no blood-feud between the Anatolian Greeks and Turks, and the Graeco-Turkish war of 1897 in Thessaly had singularly little repercussion on the other side of the Aegean. The trouble began after that. What was the status quo, that is, the relative strength of the two nationalities before they entered upon their struggle? 
The Anatolian Greeks had three great advantages: their highly-developed corporate life with its faculty for teamwork, their zeal for education, and the stimulus of having to rely on their own efforts without state-aid. The last point is the fundamental one. It was the same stimulus that the Tchechs enjoyed as compared with the Germans in Austria, or English Noncomformists and Catholics as compared with members of the Established Church. It came out most strongly in the success of their schools. A Greek school in Anatolia being supported entirely by local endowments and subscriptions, and administered by a committee representing the benefactors and beneficiaries, everybody is interested in its welfare and it is the chief object of communal pride. The Turkish schools, on the other hand, have mostly been paid for and administered by the State, and the school-masters have less direct connection with the religious and administrative authorities, perhaps still less with the local Turkish population. In contrast to the life of a Greek community, one is struck by the isolation of the Turkish civil official, gendarmerie inspector, mufti, and schoolmaster from one another. They are linked up through the Government offices at the provincial capital or at Constantinople, and Departments in Stamboul appear to be as inimical to each other's interests and activities as they are in Whitehall. Indeed, the evils of bureaucracy in Turkey are incomparably greater than in England, and far outweigh the advantage which the Anatolian Turks ought to have derived from the fact that the sums assigned to education out of the public revenue (to which the Anatolian Christians contributed their share) were in practice expended almost exclusively for their benefit. The Christians contributed compulsorily to 
Moslem education as well as paying voluntarily for their own, and they could afford to do so, largely because the superior education which they provided for themselves made them much wealthier than the Moslems per head of the population. It as an outlay which brought in an immediate and a lucrative return.

In fact, the Greeks were stronger in everything except numbers, in which, of course, the Turks had an overwhelming superiority. Before discussing this, it must be mentioned that no census had or has been taken in Anatolia or any other part of Turkey, and that all possible figures for the relative strength of denominations and nationalities rest on rough estimates, mostly made by the interested parties. The decision at the Peace Conference to send Greek troops to Smyrna did not arise from considerations of nationality, as I have attempted to show. On the other hand, after the fait accompli of the landing, the demarcation of the zone round Smyrna provisionally assigned to Greece under the Treaty of Sèvres was based on a comparison and synthesis of the data then available in print. This was all that could be done by the officials to whom the authors of the policy resorted, after the event, for justification of the fatal step which they had taken. But the most painstaking collation of these untrustworthy statistics could not approximate to the truth. ${ }^{1}$ I can only say that in February and March 1921 , when the evicted and deported Greeks had been repatriated and numbers of

\footnotetext{
${ }^{1}$ The Allied Governments tacitly admitted this at the Conference of London in February 1921. Having recognised that the mischief which they had made must be undone if possible, their first step was to propose a recount of the population in the Smyrna Zone and Thrace (see Chapter III.).
} 
Turks evicted in their turn, ${ }^{2}$ my personal impression was that even in the Sèvres Zone the Turks were in an unmistakable majority. I spent six weeks travelling over the zone under Greek auspices and took particular pains to visit the Greek communities, and I state my impression, with the reservation that no certainty is possible until an impartial investigation is made on the spot-a step proposed by the Powers, accepted by Turkey, and rejected by Greece at the Conference of London. $^{1}$

The Greeks naturally feel that numbers ought not to be decisive; that (at present at any rate) they could make far more out of the country than the Turks have done, and that under Greek control there would be a rapid increase in the Greek population. The Turks feel about Greek immigrants as the Mesopotamian Arabs do about Indian, or the Californians, British Columbians, Australians, and New Zealanders, about Chinese and Japanese. They admit that the country in which they at present constitute the majority of the population is under-populated and under-developed, and that if such immigrants were allowed free entry and a free hand, they might bring the agricultural and mineral resources of the land to their maximum of productivity at an earlier date than the nationality in possession are likely to do for themselves. But they do not consider this a sufficient ground

\footnotetext{
${ }^{2}$ I am certain that this number far exceeds that of the evicted or deported Greeks who have failed to return, through death or disinclination, since the armistice.

${ }^{1}$ See above, Chapter III., p. 93. At the Conference of London in February and March 1921, the Greek and Turkish delegations submitted quite irreconcilable figures. On the Turkish side, Dr. Nihad Reshad Bey claimed that the Turks amounted to 75 per cent. (or roughly 1,250,000 out of $1,500,000$ ) in the vilayet of Aidin, and the non-Greeks to 57 percent. in Smyrna city. On the Greek side, Mr. Ghunarákis, taking the Sèvres Zone as his area, put the pre-war population at
} 
for their being supplanted and forfeiting to new-comers the right of exploitation. Is not the latent wealth of the country their own? May they not do what they like with it? What grievance has the rest of the world if they let it lie until they or their children are ready to make use of it? This is, of course, the Parable of the Talents translated into terms of nationalism, and so far no peaceful solution has been worked out. The argument of the modern American and Australian might have been used against the original English-speaking colonists of the New World and Australasia by the Red Indians and Blackfellows, if they could have supported it by effective resistance. Unlike them, the Turkish majority in Anatolia has proved itself able to fight successfully for its point of view, and the utilitarian argument of the Greeks has been turned against its authors by their ruinous failure to assert it by force of arms.

The Hamidian status quo was disturbed at once by the introduction of parliamentary institutions, which opened a field for all the potential conflicts of nationality in Anatolia, as in other parts of the Ottoman Empire. The Turks complain that the Greeks did not use the new liberty of the Press and of elections to secure their legitimate share in the management of the Ottoman Empire, but took advantage of it to promote their own secession from Turkey and union with the Kingdom of Greece-in fact, that they accepted the position of Ottoman citizens in order to behave as traitors. The Greeks on their part complain that, while extending their nominal rights, the Young Turks had designs against the few substantial privileges which the Christian minorities had previously enjoyed. 
They assert that the Committee of Union and Progress, and especially its local branches in the provinces, preached the doctrine of 'Ottomanisatin'; demanded allegiance to the Ottoman Empire to the exclusion of traditional loyalties; foreshadowed the abolition of the 'millet' system; stirred up fanatical national and religious feeling among the Turkish masses; and created such tension that it became unsafe for the Christians in the inland town of Anatolia to travel on business or to visit their country estates.

Probably both complaints were well-founded. The Turkish revolutionaries had a simple-minded belief that a parliamentary constitution would at once remove long-standing inequalities of status and create an 'Ottoman' political consciousness among the enfranchised elements. They forgot that injustices rankle even after they are brought to an end, and they did not reckon with the momentum which Greek nationalism had already acquired in Anatolia through a century or more of existence. The Greeks could not be expected to renounce a cherished tradition and valuable prescriptive rights for the sake of a hazardous political experiment, over which they themselves would have little control. That would have been a rare sacrifice of interest and sentiment, and their refusal to make it, though it may have been narrow-minded, was not a sign of special bad faith. Exactly the same line was taken by the other non-Turkish nationalities in the Empire which had independent national states outside to look to, like the Bulgars and the Serbs. Even the Moslem Albanian and Kurdish tribesmen rebelled, to maintain the privilege of lawlessness which Abdu'l-Hamid had

Turks. (See Times, $25^{\text {th }}$ February 1921.) 
allowed them. The only non-Turks who made a genuine attempt to work the Constitution of 1908 were civilised populations, like the Armenians and the sedentary Arabs, which had no preferable allegiance as an alternative.

On the other hand the Greeks, exasperated by the glaring contrast between the Young Turks' professions of liberalism and their chauvinistic practice, made insufficient allowance for the difficulties of their position and the confusion in their minds. The Young Turks, during their exile in Paris, took current Western political thought as they found it. They were not troubled by the underlying antinomy between nationalism and democracy, its two leading ideas. They did not see that in a non-Western country with a mixed population, the two principles were dangerously incompatible. They set about applying both with unintentional inconsistency, and by the time that they were driven by events to choose between them, they had become so embittered by the attitude of the Powers and of the minorities that they sacrificed the more generous to the more militant doctrine.

Thus a serious rift had opened by the autumn of 1912, but on both sides it was the inevitable disillusionment of inexperience, and the misunderstanding might have been diminished by time. A much worse situation was created by the outbreak of the Balkan War.

It is quite impossible for Greeks and Turks to look at the First Balkan War from the same angle of vision. For the Greeks it was a war of liberation against a tyranny, incompletely successful in so far as a single Greek was left under Turkish sovereignty at the conclusion of peace. Any Turks ruling over Greeks 
were felt to be oppressors, even if they were in a local majority, for here the romantic element came in. If the Turks had secured a majority, that, in the eyes of the Greeks, was only one robbery the more. Wherever they were and whatever their numbers, they were intruders, and pretensions based on the present could be put out of count by a monument, an inscription, a legend, or a name. In any war with Turkey, Greece could not feel herself the aggressor. In invading Ottoman territory she was simply recovering what she regarded as her own. A war of liberation always seems to those who make it to be morally a war of defence, even when they take the offensive.

The Turks, on their side, felt themselves victims of a wanton attack by neighbouring states at a moment of weakness. They were weak, they believed, because they were voluntarily experimenting in those Western institutions which the Great Powers and the Near Eastern nations had always been trying to force upon them. The invaders were kinsmen of the very elements in the Ottoman Empire which had most to gain by the reforms. Yet Western public opinion was giving the invaders its benediction and the kindred minorities in the Empire were praying for their victory. In these circumstances the Turks were almost bound to forget that their weakness arose not so much from the constitutional régime itself as from their long delay in attempting the necessary adjustment of their political life to Western conditions. They did not reflect that the reforms had not so far been working very successfully, and that if they were a failure, the status of the minorities might become more unfavourable than it had been before. With the enemy assaulting the Chatalja lines and the guns making themselves heard in 
Constantinople, they could not see the other side of the case, and everything that foreigners had said about Turkey now seemed sheer hypocrisy. Not the improvement but the spoliation of Turkey must after all have been the ulterior object of the traditional denunciations.

As for the distinction between technical and moral aggression, which seemed so obvious to the Balkan peoples and their Western sympathizers, it could not survive the spectacle of streams of Turkish refugees fleeing before the face of the Serbian, Greek, and Bulgarian armies. As the Turkish forces fell back, the Christian population rose against the Moslem minority in the invaded provinces. Villages were looted and burnt wholesale; there was also murder and violation; and the reign of terror by no means ceased when the victorious states took over control. ${ }^{1}$ The hundreds of thousands of refugees who arrived at Constantinople, and kept on arriving after the conclusion of peace, were destitute and terror-stricken. The following are the figures of those who actually passed through the hands of the Ministry of Refugees (a melancholy Department of States), without allowing for the unknown numbers that were dealt with by private charity or perished before they could be assisted at all:--

$\begin{array}{lrrrrrl} & 1912-13 & 1914-15 & 1916-17 & 1918-19 & 1919-20 & \text { Total } \\ \text { A. } & 177,352 & 120,566 & 18,912 & 22,244 & 74,848 & 413,922 \\ \text { B. } & 68,947 & 53,718 & 1,252 & 6,736 & 12,536 & 143,189\end{array}$

\footnotetext{
${ }^{1}$ See Report of the International Commission to inquire into the causes and conduct of the Balkan War, ch. ii. 1 (pp. 71-7). (Washington, D.C., 1914, Carnegie Endowment for International Peace.)
} 
$A=$ Moslem refugees from all territories lost by Turkey in the Balkan Wars (191213).

$B=$ Moslem refugees from territories acquired by Greece from Turkey in the Balkan Wars (1912-13).

In 1921, I myself came across refugees encamped in mosque courtyards at Constantinople who had been in that condition ever since 1912, but the great majority were resettled, by the exertions of the Ministry of Refugees and the Ottoman Red Crescent Society, in Anatolia. Their numbers were so great that they appreciably affected the population. At Yalova, for example, when I was helping to evacuate the Turkish survivors of Greek atrocities and was making lists of names of the men of military age whom the Greek authorities were detaining, ${ }^{1}$ I found that about one in three came from the Yannina district in Epirus. At Gemlik and other places it was the same-and now the racial war, passing from Europe into Asia, had overtaken them, and they were being uprooted again. ${ }^{2}$ There had been settlements of Moslem refugees in Anatolia before-Kretans, Bosniaks, Dobrujalys, Circassians—but they had never come with such a rush, and the Circassians, though perhaps more numerous in the aggregate, had been distributed over the entire Empire. Moreover, except in the case of the Kretans, the people who had evicted them had not been of the same nationality as the local Anatolian Christian minorities, and the Kretan settlers had

\footnotetext{
${ }^{1}$ See 'Yalova,' at the end of Chapter VII., p. 299 below.
} 
been so turbulent that they had not gained the sympathy of their new Turkish neighbours and co-religionists. For all these reasons, the arrival of the Rumelian refugees from the end of 1912 onwards produced an unexampled tension of feeling in Anatolia and a desire for revenge; and so the Balkan War had two harvests of victims: first, the Rumili Turks on the one side, and then the Anatolian Greeks on the other. In writing of these events, Greeks and Philhellenes have sought to differentiate between the two cases. One pamphlet that lies before me describes the uprooted populations as 'émigrées d'une part, expulses de l'autre.' ${ }^{3}$ No such distinction is warrantable. The fundamental truth was that a number of Near Eastern Christians and Middle Eastern Moslems were bearing the brunt of one particular clash in a vast interaction between civilisations. But if differences in their degree of suffering are to be noted and compared, then surely one must judge that the Rumili Turks, who were driven out first and amid the terrors of invasion and battle, were the more unfortunate.

The Turkish reprisals against the West Anatolian Greeks became general in the spring of $1914 .^{1}$ Entire Greek communities were driven from their homes by terrorism, their houses and land and often their movable property were seized, and individuals were killed in the process. Not only communities on the coast opposite the three liberated islands of Mitylini, Khios, and Samos, but settlements

\footnotetext{
${ }^{2}$ At Constantinople I came across one family of Turkish refugees from Thrace who had been uprooted no less than six times since the beginning of the First Balkan War. Three or four successive evictions were not an uncommon experience.

3 'L'Hellénisme de l'Asia Mineure et la Jeune Turquie: Protestation et appel. . . par un témoin oculaire. ...' (Anonymous, without place or date of publication.)

${ }^{1}$ It must be remembered that the provocation was continuing. In 1914 and 1915, 53,718 fresh Turkish refugees from the Ottoman territories just annexed by Greece passed through the hands of the Ministry of Refugees. (See table above.)
} 
at some distance inland were affected. What happened at Bergama, for instance, was described to me at first hand in 1921 by repatriated exiles. One morning in the spring of 1914, the Bergama Greeks were informed by the local Ottoman authorities that they could not guarantee their safety if they remained that night in the town. Abandoning everything but what they could carry in their hands, they got down before nightfall to the skala of Dikeli, crossed over to Mitylini as soon as transport could be found for them, and remained there six years. The procedure bore evidence of being systematic. The terror attacked one district after another, and was carried on by 'chetté' bands, enrolled from the Rumili refugees as well as from the local population and nominally attached as reinforcements to the regular Ottoman gendarmerie. The definition of 'chettés' and the history of their employment may be left to Chapter VII. It is sufficient here to state that the same method was used previously in Macedonia and subsequently_against both Armenians and Turks—in this and other parts of Anatolia, and that various Near and Middle Eastern Governments have successively soiled their hands with it under parallel conditions.

In 1914 the process was happily checked before it had been applied to larger Greek centres like Vurla, Aivali, or Smyrna itself. First some restraint was put upon it by the negotiation of an agreement between the Greek and Ottoman Governments, and then it was more effectively interrupted by the European War, since, during the period when Greece was still neutral while Turkey had become a belligerent, the latter had a strong motive for refraining from action which might bring Greece in on the other side. The previous agreement was the work of Mr. 
Venizelos, and though he has been criticised on account of it by some of his fellow-countrymen, it will probably rank among the minor triumphs of his statesmanship. In an exchange of notes, ${ }^{1}$ a regular interchange of the minorities left on the wrong side of the new frontiers was provided for, and a mixed commission set up to see that the intermigration was conducted in a humane and orderly manner. The emigrants were to be given time and means to remove their portable property and to dispose of their real estate at a fair valuation-the valuations to be passed through a clearing house and each party, on their arrival in their new homes, to be compensated out of the property left behind by the others. The mixed commission contained neutral members as well as Greeks and Turks. This is the most constructive scheme that has yet been tried in the Near and Middle East for the solution of the minority problem; and if it is objected that in this case it did little to diminish the suffering and economic loss, the answer is that it was not given a fair trial. If it had been already embodied in the Treaty of Bukarest $\left(10^{\text {th }}\right.$ August 1913$)$ and had not been suspended by the intervention of Turkey in the European War (end of October 1914), it might not only have saved the minorities but have brought about a good understanding between the two countries. As it is, it is a precedent to which the utmost attention ought to be given.

From the outbreak of the European War until the spring of 1916, the West Anatolian Greeks (for the diplomatic reasons above mentioned) suffered

\footnotetext{
${ }^{1}$ Greek Government's note of $24^{\text {th }}$ June and Ottoman Government's answer of $8^{\text {th }}$ July 1914.
} 
relatively little. Certainly their position was unenviable enough, for, with the sudden cessation of Western control, the Turks behaved like children out of school. Local Christian merchants, as well as those of Entente nationality established in the country, were subjected to crushing requisitions, and Christian Ottoman subjects (who had been liable to military service since the Constitution of 1908) were mobilized wholesale. They were mostly drafted into labour battalions which, like the gangs of British prisoners from Kut, were made to work under shocking conditions and had an appalling mortality from explore and starvation. This was to a great extent due to that piecemeal assimilation by the Ottoman Government of Western military methods (discussed in Chapter I.), which often bore just has hardly upon its Moslem soldiers. At Manysa, for example, Greek inhabitants have described to me how, during the European War, the Turkish garrison was literally starving, though this was a substantial town in a peaceful agricultural district with railway communications. On the other hand, there is no doubt that the sufferings of the Greek (as well as the Armenian) labour battalions were partly deliberately brought about by the malignity of Turkish officers in charge, for which the Ministry of War, and ultimately the Ottoman Government, must be held responsible.

But unhappily this was not the worst, for in the spring of 1916 the Ottoman military authorities started deportations, first partial and then wholesale, of the Greek population along the Aegean and Marmara littoral. This may partly have been a political counter-demonstration to the establishment of Mr. Venizelos's revolutionary pro-Entente Government at Salonika, but the hostile occupation of 
the three neighbouring Greek islands by the naval forces of the Entente Powers themselves was probably the main cause. These deportations (in contrast to the previous deportations of the Armenians) bear marks of having been a genuine measure of military precaution. While in 1914 there were sporadic outrages in the interior too, the deportations of 1916-18 appear to have been practically confined to places within range of hostile naval operations. ${ }^{1}$ They were carried out with great brutality. At Aivali, for instance, which had survived in 1914, all inhabitants between the ages of twelve and eighty (that is, in effect, the entire population) were turned out of their homes on the $27^{\text {th }}$ March 1917, and some were transported great distances—-the former French vice-consul, M. Sapaunjoghlu, a gentleman of advanced age, as far as Kaisaria. But his case was apparently exceptional. The majority of the Aivaliots seem to have been transported only as far as Balykesry, and to have remained there till the end of the War; and though they suffered great hardships and were shamelessly fleeced by the Turkish peasants from whom they were forced to hire transport, they were not massacred on the road, or driven on and on till they dropped, or marooned in deadly swamps and deserts, like the still more unfortunate Armenians. The extent of their loss and suffering largely depended upon the behaviour of their Moslem neighbours. At Armudlu, a mixed Greek and Turkish village on the Yalova-Gemlik Peninsula, ${ }^{2}$ the Greek inhabitants told me in 1921 that, when during the European War they were deported to Brusa, the local Turks looked

\footnotetext{
${ }^{1}$ e.g. There was no deportation, as far as I can make out, at Manysa or Aidin.
} 
after their property for them till their return. But from what I saw myself in $1921,{ }^{3}$ I fear that such cases were exceptional. At Kinik, Bergama, Aivali, and Dikeli, I can state from personal observation that the Greek communal buildingschurches, schools, hospitals, baths-were wantonly desecrated and defaced and mercilessly ransacked, even beams and window-frames being removed; and that the private houses were thoroughly plundered and then occupied by Moslems. The destruction seemed to have been most savage at Aivali-probably because it was a self-contained Greek community and there was no local Moslem population which might have had some personal link, however little, with the deportees. Aivali was made over, after the $27^{\text {th }}$ March 1917, to Rumili Moslem refugees embittered by years of misfortune, and the damage that they did was proportionately great. In 1921 the Turkish numerals painted on the doors of the Greek houses assigned to these intruders were still visible, and it looks as if here, at any rate, the change of population was intended to be permanent.

The only possible ${ }^{1}$ defence of all this is that the deportation of potentially hostile persons from war-areas, even without definite suspicion, was practised by Western Government also_for instance, by our own Government on the East Coast. In Western Anatolia the Greeks were not only suspect as ardent

\footnotetext{
${ }^{2}$ See Chapter VII. for what has happened there since.

${ }^{3}$ I visited Kinik, Bergama, Aivali, and Dikeli, but not Phokiés, where some of the worst excesses are said to have been committed during this period.

${ }^{1}$ One defence of the Turks in this matter, which is accepted rather too readily by British, French, and American non-official residents in Turkey, is that these Anatolian deportations, too, were the work of a Western Power-Germany. The plan is attributed to General Liman von Sanders, and though it is not usually assumed that he foresaw the consequences, it is argued that he who wills the end wills the means. I have so far discovered no evidence for this allegation, which seems to rest on nothing more than the unconvincing presumption that the Turks could not have devised and executed such measures on their own account.
} 
Venizelists (that is, sympathisers with the party in Greece that wanted to intervene on what was the enemy side from the Turkish point of view), but they did actually do intelligence work for the Allied navies, as was admitted to me freely at Aivali. The fact that, instead of being a handful of 'enemy aliens,' they were Ottoman subjects and amounted to a large percentage of the population, is one of the anomalies of the present state of affairs in the East, from which both they and the Turks have suffered; and the roughness with which they were treated (as compared with persons deported or interned by the Western belligerents) did not fall below current Near and Middle Eastern standards. But any defence is wholly irrelevant. The various incentives and provocations that have been mentioned explain, but do not excuse, the Turks' treatment of the West Anatolian Greeks between 1914 and the armistice, just as the history of Macedonia since the Treaty of Berlin merely explains without excusing the Balkan Allies' treatment of the Rumili Turks in 1912 and thereafter. The important fact is that by the time of the armistice, when the victorious Western Powers became masters of the situation in the East as no group of Western Powers had ever been before, upwards of half a million Rumili Turks on the one part and as many Anatolian Greeks on the other had been cruelly affected by six years of almost continuous warfare. At that date, could the Powers have saved the situation? Could they have put an end in Anatolia to the national conflict between Greeks and Turks? Having now described, without, I think, minimising, the proportions to which the evil had then grown, I reiterate my belief that they could. 
Between the $30^{\text {th }}$ October 1918 (the date of the armistice with Turkey) and the $15^{\text {th }}$ May 1919 (the date of the Greek landing at Smyrna), the Allies had the future of Anatolia in their hands. The country was ringed round by their naval and military forces occupying the Arab Provinces, the Straits, and Transcaucasia, and was under the surveillance of control-officers superintending the execution of the armistice terms. Even in comparatively remote places, this control was working effectively until the news of the Greek landing arrived. The Turkish civil and military authorities were obeying the orders conveyed to them, troops were being disbanded, arms and munitions called in. The railways were intact (for there had been no military operations in Anatolia) and were running. The dislocation produced by the blockade was being repaired. The country as a whole was not in disorder, and though there may have been disturbances at this time in the far north-east, there certainly was no breach of the peace in the neighbourhood of Smyrna, which afterwards became the theatre of the new war. In these circumstances, there were three alternative ways of dealing with the Graeco-Turkish nationality-problem, between which the Supreme Council had to choose. One possible policy was thorough-going segregation. The respective nationalities had been so far uprooted since 1912, and national feeling so fiercely roused, that it might have seemed wisest not to reverses what had been done by violence, but only to mitigate the suffering and injustice by a belated application of the principles of the 1914 Agreement. Another alternative was to restore the status quo. The Anatolian Greeks evicted or deported since 1914 might have been repatriated, and the Turkish refugees who had supplanted 
them either resettled elsewhere in Anatolia (which was under-populated and under-developed) or given the choice of returning to Rumelia, where fair treatment could have been secured for them from the Greek Government by the Principal Allied Powers. Either of these policies could have been adopted without fresh changes of frontier. The third alternative was to carve out a sort of territorial reservation for the Anatolian Greeks in Anatolia-a policy which combined the disadvantages of the two others. It involved both a complicated redrawing of frontiers and also a reshuffling of populations (not less undesirable for being only local). It was in contradiction with the geographical structure of Anatolia, and with the economic relations between the Greeks and Turks in the country. Worst of all, it was a one-sided arrangement, giving advantages in Western Anatolia to the victorious nationality which no one proposed to give in Macedonia (where the circumstances were parallel but the positions reversed) to the defeated nationality.

However, this was the policy which the Supreme Council elected to pursue. Its consequences are sufficiently described in other parts of this book. One ultimate consequence will probably be that the first alternative-that of radical segregation—will have to be applied under conditions far less favourable than those prevailing from November 1918 to April 1919. But we have still to ask whether at that time the second alternative-the restoration of the national status quo-was really feasible? The Allied Armies in the East were in course of demobilisation. The ring of garrisons round Anatolia was in any case going to be attenuated till it almost faded away. Would the authority of the Allied control- 
officers in Anatolia have survived its disappearance? Would not Greece and Turkey in any case have taken the situation into their own hands, as they have actually done, and with just as disastrous results? Of course, either answer to these questions is hypothetical, but the negative is much the more probable. Greece could never have invaded Anatolia without the consent of the Allies, even if they had withdrawn all their troops from the East, owing to their permanent command of the sea; and Turkey would never had expelled the Allied controlofficers if there had been no Greek invasion. On the contrary, she would have felt their presence a security against the eventuality of that Greek occupation of Smyrna which, rightly or wrongly, the Turks regard as a mortal blow to their national life. It is thus exceedingly unlikely that the political situation established in Anatolia after the armistice would have been violently disturbed, and meanwhile the economic factor would have been operating powerfully to bring the two conflicting nationalities in the country together. During those six months after the armistice, the economic prospects of Anatolia were more brilliant than they ever were or probably will be. In the industrial countries of Western Europe, there was then an unprecedented demand for wheat, wool, leather, cattle, and other food-stuffs and raw materials which Anatolia produces; the internal transport system of the peninsula (though scanty) was intact; and in the temporary dearth of shipping, its proximity to the European markets gave it an enormous advantage; but above all Anatolia would have benefited by the economic disorganization and isolation of Russia, the country which normally placed the same products on the same market in greater volume. The 
opportunity was remarkable, and the French and British merchants of Smyrna and Constantinople, heavily though they had been hit by the War, started out confidently to take advantage of it. The prosperity to which they looked forward would have been shared by the Turkish agriculturist and the Greek middleman. The destruction of the previous six years (which, after all, was not comparable to the devastation of Serbia or Poland or Northern France) would rapidly have been made good; the repatriated exiles would have found their feet; common economic interest would have linked the various classes (which in Anatolia are equivalent to the nationalities) together; and the balance would have been held by that new and long-needed factor: a neutral control. Even after what had happened, I found personal links between Anatolian Greeks and Turks still holding at Manysa and Armudlu in 1921. If the Greek troops had never landed, assuredly the breach could have been healed and the status quo restored. But the policy actually chosen by the Supreme Council not only kept the wound open; it inflamed it almost beyond hope of cure.

\section{TWO RUINED CITIES}

[Written at Smyrna on $21^{\text {st }}$ February 1921.]

I approached Ancient Ephesus from the slopes of a limestone hill spangled with crimson anemones, gashed with the quarries from which the stones of the city were hewn, and crowned with the remnants of towers and curtain walls. I had chosen my direction so as to descend upon the theatre from above, and the view, suddenly disclosed, of the vast cavity, with the seats still in 
place and the stage buildings standing, was as impressive as I had expected it to be. Beyond it, the great central thoroughfare of the city, a streak of marble pavement showing up against the green of the plain, led down to the ancient harbour, now a reed-bed, yellow and brown. Parallel to the thoroughfare on our left stood the mountain of Koressos, with Lysimachus's fortifications on the skyline. Beyond, on a separate and lower hill of limestone, stood the 'Prison of St. Paul,' a tower in a salient of the city's defences. Beyond that again lay the sea, deep blue against the horizon, and to our right stretched the plain of alluvium which has choked the harbour and driven the sea away. The river Cayster, which built the plain and cooperated with the folly of man to the city's undoing, wound like a snake in spiteful loops and curves through the feverish levels which it has laid down.

The Austrian archaeologists who were excavating Ephesus before the War have only laid bare the main outlines, but the view from the top of the theatre-and still more the view from the summit of Koressos, which I climbed next day—gives one an impression of how great the city was. The vast circuit and finely cut masonry of Lysimachus's walls, the immense circumference of the harbour, an artificial basin dug in defiance of the Cayster's malice, record and ambitions of its founder. In this same spirit the Germans built the port of Haidar Pasha and the Baghdad Railway, and the prize they strove for was the samethe conquest of a commercial hinterland extending into the heart of Asia.

Lysimachus was one of Alexander's generals and heirs, and he laid out Ephesus at a moment when all Asia, from the Aegean to the Pamirs, had been 
opened to Greek enterprise by Alexander's conquests. From Ephesus, the caravan-routes led up the three rivers into the interior, as the railways lead up them from Smyrna now. But Ephesus was greater than Smyrna has ever been. In the time of the geographer Strabo (about the beginning of the Christian era) the economic hinterland of Ephesus had spread into the provinces of Sivas and Kaisaria, diverting their exports from the ports of the Black Sea, ${ }^{1}$ and it was a more prosperous as well as a wider hinterland over which Ephesus ruled. As I stood in the orchestra of the theatre and thought of the crowd shouting 'Great is Artemis of the Ephesians,' and the city clerk standing perhaps where I stood and trying to calm them down, my eye caught an inscription on the base of a vanished statue: 'To the Emperor and God Caesar Augustus Vespasianus, in the proconsulship of Lucius Mestrius Florus, the townspeople of Simav, for the temple of the Emperors at Ephesus....' The townspeople of Simav! I had seen their modern representatives the other day, coming with their strings of camels to market at Kula, inside the Greek lines—veritable types of primitive man, with wild faces and outlandish costumes. The modern Simavlys do not erect monuments in Smyrna. Civic organisation, art, and all that the marble base and its inscription imply, must be things utterly beyond their horizon. The contrast is a measure of the difference between Anatolia now and then. Modern Anatolia could not support so great a city as Ephesus, and when the crimes and blunders which ruined Ancient Civilisation had reduced Anatolia from its former to its present

\footnotetext{
${ }^{1}$ Strabonis Geographica, ed. by Meineke, A. (3 vols., Leipzig, Teubner, Classical Texts Series),
} 
condition, the city deserted Lysimachus's ambitious site and retreated to the little hill at the back of the plain where the original settlement had been. Here, out of touch with the sea (a dangerous rather than a lucrative neighbour in times of anarchy and decline), stood the Byzantine Church of St. John and the citadel walls, and below the citadel there still stands the shell of the fourteenth-century Saljuq mosque, the latest and in some ways the most beautiful monument of all. Except where a few masses of brickwork rise above the soil or where the excavators have laid marble pavements and foundations bare, Lysimachus's city has disappeared. Its extent is only indicated by the fine-ground fragments of bricks and masonry that strew the fields. Could Smyrna, the modern Ephesus, be blotted out as completely, if statesmen in London and Paris and Rome cooperated with the alluvium of the River Hermus to destroy it? I speculated on this as I walked along the ridge of Koressos and heard the Lewis guns popping a few miles away over the hills, where the economic hinterland of Smyrna is at present cut short by the boundary between the Greek and the Italian Zone. Next day I went on to Aidin, and saw how the process could be begun.

The Greek quarter of Aidin had been a miniature European city. It had its finely placed church, its well-equipped hospital, its school, its theatre, its cinema, its electric light, its flour mills, its factories for crushing olives and making soap. There were doctors and lawyers, merchants and manufacturers, a municipality and a club. This life and prosperity were a recent growth. It was one of those Greek colonies which had sprung up along the railways built from Smyrna into

Vol. II. p. $758=$ Casaubon, p. 540. 
the interior. It had survived the Committee of Union and Progress and the European War. Destruction overtook it nine months after the armistice, in July 1919, when the Greek forces, after landing in Asia Minor, made a premature advance up the Maeander Valley, occupied Aidin, and were temporarily driven out. When they reoccupied the town a few days later, this was what they found. It does not matter for the moment who began the destruction. I have heard the most conflicting accounts and do not propose to deliver a verdict, ${ }^{1}$ especially as one has been delivered already, I believe, by an inter-Allied commission which examined and reported not long after the events took place. Anyhow, whether in reprisal for previous provocation or not, the Greek quarter was reduced to ruins and the Greek community partly massacred and partly carried away into captivity beyond the Maeander. The work was deliberately done. The buildings were not destroyed in the heat of battle but burnt one by one, and there is a sudden sharp boundary between the gutted Greek houses and the intact Turkish centre of the town. Here were twisted bedsteads, there safes with holes knocked in their sides, here a shred of clothing or a boot. I was shown gardens where people were killed wholesale, and a gulley where individuals, entered on a written list, were taken out and slaughtered one by one. I visited these ruins in the late afternoon of a fine day. Below us stretched the plain of the Maeander, covered with olives and fig trees, one of the most beautiful views that I have ever seen. Above us the setting sun was turning the spurs of the mountains to purple and

\footnotetext{
${ }^{1}$ For further discussion of these events at Aidin, see Chapter VII., pp. 273-4.
} 
crimson, and my boots were grinding a rubble of brick and masonry which reminded me suddenly of the fields on the site of Lysimachus's city.

If these psychological guarantees could be brought into existence, the atmosphere would have been created for a reciprocal acceptance of some administrative machinery. The alternatives are legion, but there would be much to be said for the negotiation of a treaty between (for instance) Turkey, Greece, and the Armenian Republic of Erivan, establishing not only identical rights for the respective Armenian, Greek, and Turkish minorities in each country, but an identical system of inspection. A single commission, appointed by the League of Nations in consultation with the states concerned, and charged to inspect the relations between majorities and minorities in all their territories, would be an appropriate organ. Reciprocity and sympathy with their kin would be the main inducements for the implicit sacrifice of sovereignty by the participating states, but they might also acquire a direct interest in such an inspectorate's activities, if its terms of reference were wisely framed. Persecuted minorities are not necessarily blameless because they suffer. As has been pointed out in the last chapter, the accusations of sedition brought against them by their persecutors are often partly true, though they are generally stultified by the disproportionate savagery of the repression. An obligation of loyalty on the minorities' side is the equitable quid pro quo for a genuine conferment of rights on the part of the ruling majorities; and it should be the duty of an impartial inspectorate to examine whether the minorities, as well as the Government under which they lived, were fulfilling their engagements. If it performed this part of its functions effectively as 
the other, the minorities would be checked in their ruinous temptation to disloyalty, and if they yielded to it, the threatened Government would have impartial testimony to the fact that its measures of defence, however excessive or wrong in character, had at least not been taken without cause.

Such avenues offer the Near and Middle Eastern peoples the best prospect of eventually coming together, but reciprocity is the password. The possibility of these better relationships depends on mutual respect if not esteem, and here once more the Western factor comes in. Greeks and Turks will not learn to treat each other as equals so long as the Western public, by vulgar insults and hardly less vulgar applause, encourages them to strut like fightingcocks and stimulates all their feelings of hatred and scorn. Western sentiment about the Greeks and Turks is for the most part ill-informed, violently expressed and dangerously influential. It is an irresponsible revolutionary force-a signal instance of that fatal conjunction of unconsciousness and power which characterises the modern Western attitude towards the rest of mankind.

Among the Western public, the names 'Greek' and 'Turk' are chiefly familiar as pegs on which people hang false antitheses-always to the Turks' disadvantage, except among a small minority who are generally driven by exasperation into the opposite extreme. I have heard believing Western Christians, in comparing the Turks with the Near Eastern Christian peoples, stigmatise the former as 'incapable of progress.' These same Christian 
Westerners would be horrified at the doctrine that negroes, or women, ${ }^{1}$ have no souls. Yet this is only a theological form of the proposition which they make, with regard to the Turks, without hesitation. It is not the first case in which theological prejudice has led estimable people to count fellow human-beings among 'the beasts that perish.' Western statesmen are little better, for though they have recently become more chary of religious allusions, the other current defamations of the Turks could hardly have been more pithily formulated than they were by the Allied Governments in a note dated the $11^{\text {th }}$ January 1917 and addressed to President Wilson, in which they enumerated, among their war-aims, 'the expulsion from Europe of the Ottoman Empire, which has proved itself so radically alien to Western civilisation.' This diplomatic document and the sectarian prejudice alluded to above cover between them the principal fallacies by which the confused relations of the Greeks and Turks with the West and with one another have been worse confounded. These are the three false antitheses of Christianity and Islam, Europe and Asia, civilisations and barbarism. They are so deeply rooted in Western minds and so unfortunate in their effect upon the minds of Near and Middle Easterners that, at the risk of pedantry, I shall attempt to confute them.

The first is false because 'Christian' is not equivalent to 'Western' nor 'Islam' to a negation of Western ideals. The name of Christianity, though borne

\footnotetext{
${ }^{1}$ But I have heard this doctrine as regards women attributed by them-I believe with no foundation whatever-to Islam. The doctrine about Negroes was, of course, propounded by
} 
in common by the religions which most modern Westerners and Near Easterners and a small minority of Middle Easterners profess, is not the mark of any contemporary community of religious ideas and institutions, ${ }^{1}$ but merely a record that three now distinct civilisations have a single parent in common. The early Christian Church was the last phase of Ancient Hellenic or Graeco-Roman society, which died after it had had intercourse with other societies and had given birth to several children, and these children have spent a considerable part of their lives in disagreeing with one another. The Middle Eastern Christianity of the Nestorian and Monophysite Churches (religions begotten of Hellenism by the spirit of Ancient Mesopotamia and Egypt) parted company with the Catholic Church as early as the fifth century after Christ. These movements of dissent were the first attempts of the reawakening Middle East to undo the preceding process of Hellenisation. They were, in fact, the forerunners of Islam, which accomplished the spiritual liberation to which they aspired. Again, the Near Eastern Christianity of the Orthodox Church parted company with the Western branch of the Catholic Church in the eighth century, when the divorce took place between modern Western and Near Eastern civilisation. From the respective dates of these schisms, the several Christian churches, though they have kept their family name, have had no religious experiences in common. The other churches have no part or lot in the great men and movements of our Western

\footnotetext{
Protestant divines in the Southern States of the American Union before the Civil War. The Turks, like other Moslems, are free from prejudice about colour.

${ }^{1}$ Except, of course, among converts to (or Uniates with) Roman Catholicism and Protestantism from the Orthodox, Monophysite, and Nestorian Churches.
} 
Christendom from Gregory the Great onwards, nor we in theirs. Our 'common Christianity' is not a living fact, but a historical curiosity.

Islam, on the other hand, is not a totally alien and contradictory ideal of life, as Westerners vulgarly believe. Its relation to Western Christianity differs in degree rather than in kind from that of Monophysitism. In their theological disguise, both were monotheistic reactions against trinitarianism (of different form and intensity), and in their essence revolts of the Middle East against Hellenism. At the same time, both had in their veins the blood of the parent whom they repudiated. The influence of Ancient Greek originals upon early Islamic literature, of Roman upon Islamic law, and of Hellenistic upon Islamic ideas and institutions is more and more engaging the attention of modern Orientalists.

But is Islam incompatible with progress? I am writing these lines in the year of the Hijra 1340, which, reckoning by solar years, is the thirteen hundred and fifty-fourth since the birth of the founder. ${ }^{1}$ As we cannot look into the future, let us take a parallel from the past and imagine a detached and philosophic observer speculating about the future of our Western civilisation towards the middle of the fourteenth century after Christ. We will not suppose him a Moslem (who might be suspected of anti-Christian prejudice) but a Far Easterner-for example, some Chinese statesman who has been convinced by his Confucian education of the equal absurdity of all theistic religions. He has travelled,

\footnotetext{
${ }^{1}$ Muhammad was 'probably born in the year A.D. 571. His Hijra or migration from Mecca to Medina, from which the Islamic era is reckoned, occurred in A.D. 622. The year of the Islamic calendar is a lunar one.
} 
perhaps, on an embassy from the last sovereign of the Mongol Dynasty round various courts of Western Europe. What are his conclusions in the memoir for the Imperial Academy of Sciences which he has composed after his return? 'These Westerners,' one fancies him writing, 'are still children. They are not altogether unpromising. They have some charming arts and crafts and a noble architecture; they have started interesting experiments in municipal government; their vernacular poetry has recently made strides, and like ourselves they possess the priceless treasure of an ancient classical literature, though through ignorance and indifference they have lost the better half of it. Their characteristic qualities are a rude vitality and an aptitude for war. It is a pity that this nascent civilisation, in spite of the good elements which it contains, is precluded from all possibility of progress by its deplorable religion and even more deplorable ecclesiastical institutions. The dogmas are childish, the priesthood power-loving, the spirit fanatical. I see no prospect of this incubus being shaken off. Christianity has wound itself like a python round the limbs of young Western society. A few more generations, and it will have crushed and devoured its victim.'

This hypothetical appreciation could have suggested itself, I believe, to quite a competent outside observer of that particular moment in the long course of Western history, and yet, with the Renaissance beginning and the Reformation in sight, it would have been fantastically wrong. Can we be any surer of our ground in forecasting the effect of Islam upon the future of Middle Eastern civilisation? The general proposition that Islam is incompatible with progress is 
sufficiently disproved by the past. The religion has surely gone through as many phases and affected as many sides of life as the various branches of Christianity had done by the fourteenth century of their existence, and the society that has taken shape inside the Islamic chrysalis has evinced a capacity for breaking out into an independent life of its own. The original nomadic institutions of the Ottoman Empire and its modern experiments in Westernisation have doubtless been influenced, and the latter perhaps retarded, by Islam, but they have not been inhibited.

The unconscious grievance of the West against Islam is not that Islam is incompatible with progress of any kind, for we are practically indifferent to progress or stagnation on Islamic lines. We really resent the fact that Islam offers an alternative system of life to our own. Rightly or wrongly, we consider this alternative inferior, and we feel that if only it were not held before them, the peoples that at present cling to it might have caught us up at one stride and entered into full possession of the best that we have to offer them. The fact that the other branches of Christianity (for reasons suggested in Chapter I.) have ceased to exercise a rival attraction upon their adherents is what secretly commends them to us, rather than their identity of name with our religion; and, on account of this rather negative virtue, the Eastern Churches are sometimes tenderly regarded by Westerners who have no love for Western Christianity, but who retain a human pride in the prestige and the attractiveness of Western civilisation. But do Westerners who have this secret quarrel with Islam feel unmixed satisfaction at the results of the unreserved abandonment of their own 
traditions and pursuit of Western ideals by Near Easterners? Or, to bring the argument home, do they reproach our comparatively backward Western ancestors of the fourteenth century because they did not try to exchange their painfully developing individuality for some temporarily more advanced form of life, like that of fourteenth-century Far Eastern society? Do they regard this as a gran rifiuto, and regret it from our point of view as a loss of valuable possibilities? Those are the logical corollaries of their attitude towards Islam. But perhaps they are able to realise in our own case that distinctive traditions of civilisation cannot be surrendered or borrowed $b$ a society precipitately without a general shock to its system, which is likely to tell more heavily in the long run than any immediate gains which this or that organ might make by the change.

The second antithesis, between 'Europe' and 'Asia,' is false, to begin with, because the Greeks are not specially at home in the one continent nor the Turks in the other, and also for the more fundamental reason that the so-called continents themselves are fictions, with no relation to the real geographical entities. If one took the conventional boundaries seriously, one might indeed have to class the Modern Greeks as Asiatics and the Osmanli Turks as Europeans. It has been mentioned in Chapter I. that the cradle of the Modern Greek people, of the East Roman Empire, and of Near Eastern civilisation was Central and Eastern Anatolia. The first piece of free Greek soil in modern times was Aivali; ${ }^{1}$ and Koraís, the first Modern Greek man of letters to be treated as an

\footnotetext{
${ }^{1}$ See Chapter IV., pp. 121-2.
} 
equal by Western intellectuals, came from Smyrna. On the other hand, the Ottoman state found its destiny on the continent of Europe. It was the conquest of Thrace and Macedonia that differentiated it from the other Turkish principalities of Anatolia, and the strength derived from these European possessions that enabled it eventually to conquer its Asiatic neighbours. The centre of gravity remained in Rumili down to the Berlin Treaty of 1878; its transference to Anatolia was only faced by the Turkish nation after the Balkan War, and was not avowed till Mustafa Kemal Pasha summoned the Great National Assembly to Angora in 1920.

But 'Europe' and 'Asia' are conventions which are only possible on a small-scale two-colour map. The scientific physical geographer knows of no barrier between the two continents. In the tundra-zone or the forest-zone or the steppe-zone, where is the division? Or at what point does one pass out of Europe into Asia along the Trans-Siberian or the Trans-Turkestan Railway? What are the political frontiers between Russia or Turkey 'in Europe' and Russia or Turkey 'in Asia'? The boundary between the continents, which bisects their city, does not disturb the inhabitants of Constantinople, many of whom sleep in Asiatic houses and earn their daily bread in European offices, with a pennysteamer to take them to and fro. Again, when one comes to the Aegean, one finds no boundary there. The European mountain ranges which dip under the sea at Athos and Sunium raise their crests above the waves in chains of islands, and reach over into Asia from the peninsulas of Cheshmé and Mykáli and Knidos. The physiographical unity of the Aegean basin, without distinctions of 
continents, is the strongest point in the claim advanced by Greece to Smyrna, and what is true of the Aegean holds on a larger scale for the entire Mediterranean. The traditional partition of Eurasia into two continents is unreal, and the Ancient Greek scientists who first introduced it as a parochial division in their miniature world, never succumbed to the illusion that there was some mysterious difference of soil or climate predisposing 'Asiatics' to vice and 'Europeans' to virtue. After giving full weight to the environmental factor, they concluded that the human differences which were so striking in their own day, were functions not of continents but of cultures, and they attributed most importance to the political dissimilarities between Hellenic and Ancient Middle Eastern society. 'Both the Hellenic and the non-Hellenic inhabitants of Asia,' as one of them observed, 'who happen not to be under autocractic government but to be independent, and who therefore exert themselves for their own benefit, are the most warlike people in the world. ${ }^{1}$

The real entities of human geography, which are cultural and which in this book have been called civilisations, have been defined in Chapter I., and the vulgar conception of 'Europe' is, of course, a confusion between the fictitious continent and the reality of Western civilisation. 'Western' is what people mean when they talk of 'European' in this connection. Yet Western civilisation grew up

\footnotetext{
${ }^{1}$ Corpus Hippocrateum: De Aeribus, Aquis et Locis, ch. xvi. (edited by Kuelewein, H., Leipzig, 1894, Teubner).
} 
in Western Europe only ${ }^{2}$ and succeeded in crossing the Atlantic and seeding itself in the New World before it made any headway, east of Riga and Cattaro, in those 'European' countries where other cultures had already encumbered or exhausted the ground. If the Allied statesmen were right, and being 'radically alien to Western civilisation' is a valid reason for 'the expulsion from Europe of the Ottoman Empire,' any other non-Western European states, beginning with Greece herself, will have to pack their bags and remove their baggage. But 'Europe for Westerners only' is a monstrous and a most impolitic claim, for, if titles go by continents, what standing have we Westerners, who have colonised the four quarters of the world, to our holdings in America, Africa, and Australasia? This is not a line of argument which Australians would like to present to the Japanese, or South Africans to the Bantus.

The third false antithesis, between civilisation and barbarism, is generally more picturesquely expressed. The Greeks 'have Hellen the son of Deucalion to their father,' while the 'Unspeakable Turk' is a 'nomad from the steppes' and shares the odium of the Scythian, the Mongol, and the Hun. This is the greatest nonsense of all. If it is a question of physical transmission, our Modern Greek contemporaries have about as little Hellenic blood in their veins as our Osmanli contemporaries have of nomadic. If it is one of spiritual heritage, I hope I have sufficiently demonstrated that the Hellenic civilisation of the Ancient Greeks and the Near Eastern civilisation of the Modern Greeks are totally distinct from one

\footnotetext{
${ }^{2}$ The name 'Evrópi' is ordinarily used by the Modern Greeks in this sense, as a term excluding
} 
another; that we Westerners have as good a claim as any Near Easterners to be the true Hellens' spiritual descendants; and that there is even a perceptible Hellenistic strain in the Osmanlis' Middle Eastern culture.

The common statement that Ancient Greek literature was handed down to us by the Modern Greek refugees from the final wreck of the East Roman Empire in the fifteenth century, is inexact. The Modern Greeks did copy, preserve, and eventually sell to Western Connoisseurs the manuscripts of the Ancient authors. They also kept alive a knowledge of the grammar and vocabulary of the Ancient language. But the part played by Modern Greeks in the revival of Classical Greek studies in Western Europe and America has been remarkably small. From the end of the fifteenth century onwards, the whole reconstruction and reinterpretation of the Greek Classics has been done by Western scholars. The Modern Greeks provided the texts and the linguistic key, but the most important qualifications of the Western Grecians were their previous familiarity with the Roman adaptations of Ancient Greek literature and their membership in a living society which rivalled the greatness of Hellas in her prime. Koraís, the great Modern Greek scholar who made the fruits of Western Classical scholarship accessible for the first time to any considerable number of his fellow-countrymen by editing the Classics with introductions and notes in the Modern Greek language, went as a young man to the French University of Montpellier to study medicine; was diverted from technology to scholarship under the influence of his Western professors; and spent the remaining forty-six years of a long life in 
Paris, where he found a more congenial atmosphere for Ancient Greek studies than on the classic soil of his native Smyrna.

It is worth noting that the differentiation of Near Eastern from Ancient Hellenic culture came about by a deliberate breach with the past, and not by a tearful parting. The Academy of Athens, founded by Plato, was not broken up by the Turks. It was closed, in the ninth century of its existence and just forty years before the first Turks visited Constantinople, ${ }^{1}$ by Justinian, the Near Eastern sovereign who built Aya Sofía and who figures as a worthy in the legend of Modern Greek nationalism. Seven philosophers who refused to embrace the Christian religion took refuge in the dominions of Justinian's Middle Eastern rival Khosru, ${ }^{2}$ and the Persian Government stipulated for the repatriation and toleration of these last representatives of Hellenic culture in a treaty of peace with the East Roman Power. ${ }^{3}$ The cult of the Olympian gods survived three centuries longer in the Mani, the most inaccessible promontory of the Morea, which was cut off from the East Roman Empire by the Slavonic migrations at the close of the sixth century. But in the latter part of the ninth century, when the Moreot Slavs had been reduced to subjection, this scandalous survival of Ancient Hellenic usages attracted the attention of the Constantinople Government. The Olympian cults of the Maniots were suppressed and the last taint of Hellenism

\footnotetext{
${ }^{1}$ The Academy was closed in A.D. 529; the first ambassadors from the Khan of the earlier Turkish Empire in Central Asia arrived at Constantinople in A.D. 569.

${ }^{2}$ It must be admitted that the Hellenic philosophers did not find themselves at home at the Middle Eastern court.

${ }^{3}$ In A.d. 533.
} 
was purged out of the Near Eastern world. ${ }^{4}$ The repudiation of the Hellenic tradition had already been symbolized by a change in the use of names. 'Hellene' had come to mean a heathen outsider, in contrast to the Christian subject of the East Roman Empire. The latter was the orthodox pattern of the primitive Modern Greek, and Romyós, or 'East Roman,' as has been mentioned in Chapter IV., became the national name in the vernacular. The Modern Greek merchants and peasantry of the Ottoman Empire only learnt to call themselves Hellenes from the children of the French Revolution in the West, who delighted to speak of Switzerland as the Helvetian Republic and to have their portraits painted in the costume of Roman Senators. This classical affectation was a Western fashion which the Modern Greeks borrowed with other promiscuous properties of our puppet-show, just as the classical scholarship of Koraís was a part of his enlightened advocacy of Western culture among his fellowcountrymen.

This profound student who so impressed by the alienness of the Near Eastern spirit both from the Modern West, to which he had given his spiritual allegiance, and from Ancient Hellenism, to which he turned for the same inspiration as his Western models, that in his writings he frequently attacked the greatest of all Near Eastern institutions, the East Roman Empire.

'If the Graeco-Roman Emperors had given to the education of the race a small part of that attention which they gave to the

\footnotetext{
${ }^{4}$ See Konstandínos Porphyroyénnitos (='Constantine Porphyrogenitus'): On the Administration
} 
multiplication of churches and monasteries, they would not have betrayed the race to other rulers more benighted than themselves.

For all the evils which we have suffered from the maniac Moslems, we are indebted to those fleshly and material-minded Christian Emperors. ${ }^{11}$

Koraís's verdict is borne out by the following passage from the memoirs ${ }^{2}$ of his contemporary Theódhoros Kolokotrónis, one of the most celebrated Moreot captains in the War of Independence:--

'In my young days, ${ }^{3}$ when I might have learnt something, schools and academies did not exist. There were hardly a few schools in which they learnt to read and write. The old-fashioned hoja-bashys, who were the local notables, hardly knew how to write their own names. The majority of arch-priests knew nothing but their ritual, and that only by picking it up; not one of them had been properly taught. The Psalter, Chant Book, Book of Offices, and other prophetical works were the books I read. It was not till I went to Zante ${ }^{1}$ that I came across the history of Greece in plain Greek. The books I read often were the History of Greece, the History of Aristoménis and Gorgó,

of the [East Roman] Empire, ch. 1. (ed. by Bekker, I., Bonn, 1840, Weber).

${ }_{1}^{1}$ Koraís: Apánthisma Epistolón, pp. 46-7; cp. pp. 4 and 133 (Athens, 1839).

${ }^{2}$ Kolokotrónis, Th.: Dhiíyisis symbándon tis Elinikis Phylis (1770-1836), $2^{\text {nd }}$ ed. (Athens, 1889 , Estía).

${ }^{3} \mathrm{He}$ was born in 1770 .

${ }^{1}$ An island then under British occupation, which had been under almost uninterrupted Western government for the preceding six centuries. Upper-class Zantiots used to complete their education in Italian universities. 
and the History of Iskender Beg. It was the French

Revolution and Napoleon, to my mind, that opened the

eyes of the world.'

The klepht was as well aware as the scholar of the quarter from which light and warmth were beginning to radiate through the Near and Middle Eastern dusk. Neither of them tried to pretend that the sun that was showing its face in their western heavens was a refracted image of Ancient Hellenic Hyperion, who had descended for ever into the shadowy underworld. That myth is one of the extravagances of Western Philhellenism.

Equally extravagant is the frequent reference of anything that is or is thought to be objectionable in Osmanli psychology and institutions to the influence of nomadism. ' 'Grass does not grow where the Turkish horse-hoof has trod!' Whichever conquered nationality invented this much-quoted proverb had evidently no acquaintance with the economics of life on the steppes. Had the

\footnotetext{
${ }^{2}$ So subtle a writer as Sir Charles Eliot seems to slip into this rut in his brilliant book on Turkey in Europe (revised edition, London, 1907). In describing the proclivity shown even by cultivated and well-to-do Turks for living from hand to mouth, taking things as the find them, and omitting to furnish their houses or to keep them in repair, he suggests that it may be due to some kind of inherited nomadic instinct. I feel great diffidence in criticising an observer of such ability and penetration, but a comparison between accounts of Modern Turkey and of the Southern States of the American Union before the Civil War suggests to my mind what is perhaps a less far-fetched explanation. If one reads standard descriptions of the South, like Olmsted's, one cannot fail to be struck by the apparent resemblance, in this very respect, between old Southern and contemporary Turkish life and manners. Can one discover a common cause? I believe that one can. In both societies there was the conjunction of a racial ascendency with an abnormal mobility of population. In the South it was a white ascendency over Negroes, in Turkey a Middle Eastern ascendency over Near Easterners. In America the movement of population was due to the economic attraction of the untenanted West, in the Ottoman Empire to the eviction of the outlying Turkish minorities by their former Near Eastern subjects. But this conjunction of circumstances, however brought about, might well have the same rather demoralising and unsettling effect upon the ruling element in either society, and a very natural form of it would be the encouragement of
} 
metaphor any relation to reality, those primaeval Turks who first took to stockbreeding would not have survived their first twelve months in business, for the nomad moves in an annual orbit, and drives his herds each season over the ground on which he has pastured them at the same season the year before. His perpetual motion is not a symptom of waywardness and perversity. It is as scientific as the agriculturist's rotation of crops or performance of different operations in different fields at different times of year. Both are perpetually shifting the scene of their activities in order not to exhaust a particular parcel of ground. There is only a quantitative difference in the range of their oscillation, conditioned by the difference between their media of productivity. The nomad, ranging widely in order to convert grasses into human food through chemical transformations in the bodies of tame animals, regards the agriculturist as a stickin-the-mud. The agriculturist, raising edible seeds and roots in sufficient quantities out of a much smaller area of land, regards the nomad as a vagabond.

There would be nothing more in this than the common-place mutual contempt of different trades, if the frontiers between nomad's land and peasant's land were stable. On his own ground, each of them is following that mode of life which the experience of generations has shown to be economically the most productive. He is in equilibrium with his environment and therefore more or less harmless and amiable. In fact, the nomad who visits the peasant or the peasant who visits the nomad at home is generally agreeably surprised at the courtesy of his reception. 'Those splendid horse-dairy-farmers the Abioi, who live on a milk 
diet and are the justest of mankind,' is the earliest reference to the Central Asian nomads that I know of in the literature of a sedentary society, ${ }^{1}$ and if nomads were literary-minded, I daresay they would compliment us occasionally in equally gracious phraseology. The traditional bitterness between peasant and nomad arises from a physical cause for which neither is to blame. Their respective environments and the frontiers between them are subject to periodic change. Recent meteorological research indicates that there is a rhythmic alternation, possibly of world-wide incidence between periods of relative desiccation and humidity, ${ }^{2}$ which causes alternate intrusions of peasants and nomads into one another's spheres. When desiccation reaches a degree at which the steppe can no longer provide pasture for the quantity of cattle with which the nomads have stocked it, the herdsmen swerve from their beaten track of annual migration and invade the surrounding cultivated countries in search of food for their animals and themselves. On the other hand, when the climatic pendulum swings back and the next phase of humidity attains a point at which the steppe becomes capable of bearing cultivated roots and cereals, the peasant makes his counteroffensive upon the pastures of the nomad. Their respective methods of aggression are very dissimilar. The nomad's outbreak is as sudden as a calvary charge, and shatters sedentary societies like the bursting of some high explosive. The peasant's is an infantry advance. At each step he digs himself in with 
mattock or steam-plough, and secures his communications by building roads or railways. The most striking recorded examples of nomad explosion are the intrusions of the Turks and Mongols, which occurred in what was probably the last dry period but one. ${ }^{3}$ An imposing instance of peasant encroachment is the subsequent eastward expansion of Russia. Both types of movement are abnormal, and each is extremely unpleasant for the party at whose expense it is made. But they are alike in being due to a single uncontrollable physical cause, and it is as erroneous to attribute its workings to human wickedness in the one case as in the other. Yet while the intrusive nomad has been stigmatized as an ogre, the intrusive peasant has either escaped observation or has been commended as an apostle of civilisation. The reasons for this partiality are clear. One is that the nomad's tactics are more dramatic than the peasant's and make a correspondingly greater impression on the imagination. The other is that history is written for and by the sedentary populations, which are much the most numerous and sophisticated portion of mankind, while the nomad usually suffers and pines away and disappears without telling his tale. Yet, if he did put it on record, he might paint us as monsters.

\footnotetext{
${ }^{2}$ See Dr. Ellsworth Huntington's works passim, but especially The Pulse of Asia (Boston and New York, 1907, Houghton Mifflin Co.), and The Climatic Factor as illustrated in Arid America (Washington, D.C., 1914, Carnegie Institution).

${ }^{3}$ Research has not yet proceeded far enough on the meteorological side to infer the length of period with any certainty from the scientific data. But the historical records of movements of population produced by this now well-established physical cause, point to a total period-length of 600 years between the respective 'wet' and 'dry' maxima. We are probably at present in the early stages of a 'wet' phase, the last 'dry' phase having extended from about 1550 to 1850, the preceding 'wet' phase from 1250 to 1550 , and the previous 'dry' phase—of which the Turkish and Mongol explosions were a consequence-from A.D. 950 to 1250.
} 
The relentless pressure of the cultivator is probably more painful in the long run, if one happens to be the victim of it, than the nomad's savage onslaught. The Mongol raids were over in two or three generations; but the Russian colonisation, which has been the reprisal for them, has been going on for more than four hundred years-first behind the Cossack lines, which encircled and narrowed down the pasture-lands from the north, and then along the Trans-Caspain Railway, which stretched its tentacles round their southern border. From the nomad's point of view, a peasant Power like Russia resembles those rolling and crushing machines with which Western industrialism shapes hot steel according to its pleasure. In its grip, the nomad is either crushed out of existence or racked into the sedentary mould, and the process of penetration is not always peaceful. The path was cleared for the Trans-Caspian Railway by the slaughter of Türkmens at Gök Tepé. ${ }^{1}$ But the nomad's death-cry is seldom heard. During the European War, while people in England were raking up the Ottoman Turks' nomadic ancestry in order to account for their murder of 600,000 Armenians, 500,000 Turkish-speaking Central Asian nomads of the Kirghiz Kazak Confederacy were being exterminated—also under superior orders—by that 'justest of mankind' the Russian muzhik. Men, women, and children were shot down, or were put to death in a more horrible way by being robbed of their animals and equipment and then being driven forth in winter time to perish in

${ }^{1}$ In 1881. 
mountain or desert. A lucky few escaped across the Chinese frontier. ${ }^{2}$ These atrocities were courageously exposed and denounced by Mr. Kerensky in the Duma before the first Russian Revolution, but who listened or cared? Not the Tsar's Government, nor the great public in the West.

So much, in vindication of the genus Hun. But even on the assumption that they are a generation of vipers, is nomadic ancestry as irretrievable as original $\sin$ ? If it is, then where are we to stop? We may give up the nomaddescended Near Eastern Bulgars, and even the Westernised Magyars, as lost souls. (After all, they were both on the wrong side of the War!) But what about all the other nations of the Western world-including incidentally the French, the Belgians, the Italians, and ourselves-who speak languages of the IndoEuropean family? ${ }^{3}$ Does not our speech bewray us and convict us of the ineffaceable nomadic taint? Where did these languages come from? Our Western philologists trace them back to the same steppes from which the Turanian languages issued later. At any rate, the migrants who propagated one branch of Indo-European speech in Persia and India must have crossed the steppe to get there, and could hardly have lived except by practising the nomad economy on their way. ${ }^{1}$ Yet their dubious origin is never cast up against the

\footnotetext{
${ }^{2}$ For details see Czaplicka, M.A.: The Turks of Central Asia in History and at the Present Day (Oxford, 1918, Charendon Press), p. 17. The respective estimates of the total numbers of murdered Kazaks and Armenians are both conjectural.

${ }^{3}$ The only populations in Western Europe, besides the Magyars, who speak non-Indo-European languages are the Finns and Lapps (incidentally both 'Turanian'), and the Basques-honourable exceptions, but hardly numerous enough to save our reputation!

${ }^{1}$ This conjecture is supported by the fact that the Iranian and Sanskrit names for the staple agricultural instruments are not derived from the same roots as those common to so many Indo-
} 
speakers of the modern Iranian and Prakrit vernaculars, even by those Westerners who are least inclined to believe that natives of India will ever be capable of governing themselves. Not only the morphology of the Sanskrit language, but the mythology and institutions of those proximate descendants of nomads who first gave that language its literary form, have been extravagantly admired by Westerners too fastidious to overlook the nomadic ancestry of the Osmanli Turks.

Such inconsistencies make havoc of the prejudice that nomads generically are abominable, and few words need be wasted in exposing the fallacy in the case of the Osmanlis. It has been mentioned in Chapter IV. that, for good or evil, they have actually inherited an infinitesimal quantity of nomadic blood; and in Chapter I. some allusion has been made to their experiment in governing sedentary subjects by an adaptation of nomadic institutions. If they are to be condemned because that experiment broke down, or because they have bungled in borrowing Western institutions as a substitute, they cannot fairly be accused at the same time of never having got out of their unfortunate nomadic habits. An unprejudiced study of Ottoman history does point to the conclusion that, down to the latter part of the seventeenth century, their secular institutions (apart from the immense field covered by the system of Islam) were to a large extent conditioned by their nomadic antecedents. But it indicates equally strongly that, at any rate the use of these implements during their migration and rediscovered or borrowed them independently. 
since the time of Sultan Mahmud II. (1808-1839), the traces of nomadic influence upon their social life and politics have disappeared.

The best commentary on all this false history and false sentiment which prejudice the thoughts of the Western public about the Greeks and the Turks (on the rare occasions when it thinks about them at all) is the judgment of those Westerners who speak from personal experience. They are few in number, but they are mostly educated men, and the different vocations which have drawn them to the Near and Middle East enable them to see the situation from independent points of view. Some have gone as business men, others as soldiers, others as doctors, others as consuls, others as missionaries. Any point on which the majority of these diverse first-hand observers agree, cannot easily be dismissed as a delusion; yet they are almost unanimous ${ }^{1}$ in the verdict that, as an individual human being in the local environment, the Turk is not the Greek's inferior. They find him no less honest in his dealings, no less admirable in his character, and no less pleasant as a companion.

This consensus among Westerners who have had direct relations with both nationalities cannot possibly be the product of Turkish propaganda. In the first place, the people who hold this view have formed it as the result of experience; and, secondly, the Turks, as a nation, are almost ludicrously innocent of the propagandist's art. The difference between Western and Middle

\footnotetext{
${ }^{1}$ The chief exceptions are, of course, to be found among the missionaries, but (i) whenever I have heard the maintain the superiority of non-Western Christians over Moslems, it has been a
} 
Eastern social conventions has restricted those forms of personal contact on which propaganda (as well as the more reputable forms of self-revelation) largely depends. The revolution in the position of Turkish women, which has been in progress for the last ten years, is beginning to break this barrier down, but it is still there. In addition to this material obstacle, there are subjective inhibitions. The Turks are aware of the prejudice against them that exists in Western minds, and are inclined to despair of the possibility of overcoming it. This pessimism arises partly from discouraging experiences and partly from pride, for the Turks have not lost possession of their distinctive Middle Eastern civilisation. It may have been a failure; it may even be inherently inferior to that of the West, yet it is, after all, a system of life which is a law unto itself and has its own standards and ideals. The more the West displays contempt and aversion, the more it discourages the Middle East from the pursuit of a modus vivendi and impels it to retire into itself. If there is any question of propaganda, it is on the other side. This questionable art, which is unfortunately characteristic of Western culture (the very name having originated in the bosom of our greatest Western institution, the Roman Catholic Church) has been acquired by the Greeks with uncommon virtuosity. The Greek colonies in the principal urban centres of the Western world, with their intimate affiliations-through business, naturalisation, and intermarriage — with 'influential circles' of Western society, are admirably equipped for practising it. They will themselves be the first to admit that they have not neglected their opportunity. This is not to their discredit, but it does 
suggest that the influence of propaganda is to be traced in the second-hand opinions of the majority of the Western public that has stayed at home, rather than in the first-hand experience of the minority that has been in contact with the Greeks an the Turks in their native surroundings.

The natural explanation of this minority's judgment is that it is correct, in so far as categorical judgments are applicable at all in a realm of relativity, where the positions of Greeks, Turks, and Westerners are changing all the time in respect of one another. If 'suggestion' plays any part, it is rather an 'inverse suggestion' set up by the false prejudice with which the Western observer on the spot has previously been indoctrinated. The mental associations of 'Christianity,' 'Europe,' and 'Hellenism,' which the Modern Greeks have taken such pains to attach to their own image in Western minds, are really prejudicial to them. Because (as I have tried to show) they do not correspond to the facts, they cause embarrassment as soon as Greeks and Westerners who have theoretically accepted them attempt to establish personal relations. Each finds himself in a false position. The Greek assumes a character which he does not possess. He poses as a scion of Ancient Hellenic society, who has rejoined his long-lost Western brother after an interval of adversity, due to the accident of a brutal barbarian conquest. The Westerner, on his side, starts from the generous assumption that the only essential difference between them consists in his own accidental better fortune, and that if the Greek bears the marks of what he has been through, it is only delicate to draw a veil over a temporary infirmity. From 
the moment of contact, however, these mutual assumptions begin to break down, and the process of disillusionment is so awkward, and sometimes even painful, for the Western party to the relationship that he tends to bring it to an end and to avoid its renewal. In fact, he often cherishes a quite unjust resentment against the Modern Greek, because the latter does not come up to expectations which he would never have entertained if he had exercised his judgment. It is not to the interest of either Greeks or Westerners that this source of misunderstanding should be perpetuated.

This phenomenon in the relationships between people of different civilisations is a commonplace in those between individuals of different classes in the same society. A cultivated class, for example, finds most difficulty in getting on with another which has acquired part—but only part—of its culture and customs, and which seeks on this account to establish the convention that no class-distinction is there, when both parties are secretly aware of its presence. On the other hand, it is comparatively at ease in its intercourse with members of one which makes no pretensions to similarity. In this relationship both parties can be themselves, and they can each enjoy the experience of discovering the other's distinctive qualities, without the discomfort of detecting insincerity in his attitude and their own. Indeed, this relationship inclines people to be, if anything, unduly charitable. Each party having assumed that the other's standards differand that legitimately—-from his own, is easily led to suspend judgment. A working-man often makes allowances for an acquaintance who is a gentleman, and a gentleman for a working-man, which they would not either of them make 
readily for individuals of their respective species, or ever for a shopkeeper. This well-known psychological fact has not been without benefit to the Turk. When a Westerner meets a Turk (whether it be an unsophisticated peasant or a Westerneducated doctor, official or officer), he finds himself in contact with an individual who has traditions, standards, manners, and a soul of his own. Social relations with him are straightforward and full of interest. They possess all the charm and vividness of intercourse with a live human being, with a minimum of those moral commitments which ordinarily follow. The Western traveller takes the same aesthetic enjoyment in his live Turk as in the fictitious personalities of a novel or a play, or as in the ghosts of a dead civilisation. The author, and every reader after him, of Paradise Lost can idealise and sympathise with Satan in the imaginary world of that poem, without having to feel the disapproval obligatory when much less serious offences are committed in this world by sons of Adam. Scholars, too, can take delight in the poetry of Aeschylus, the heroism of Leonidas, and all the glories of Ancient Hellenic civilisation, without being unduly distressed by the paederasty and infanticide which co-existed with them. In the same way, a Westerner who has once made friends with a Turk will shake hands with him again, next time he visits Turkey, without embarrassment, however red the hands of other Turks may have been stained, since his last visit, by massacre. Without his being aware of it, the conventional picture of the 'bloodstained Turk,' with which he has been familiarised since infancy, has made him proof against being shocked by the reality. This feature in the personal relationship between Westerners and Turks, on its present footing, is as 
undesirable as that noted above in the case of Westerners and Greeks; but it has the same psychological origins, and neither feature will disappear until the ‘complex' of prejudice in Western minds has been removed.

It is imperative to remove it, for unwarrantable prejudice and unwarrantable indulgence do not in this case counter-balance one another. When you have made a spoilt-child of the Greek, it is no good rounding on him as an impostor; and when you have used the Turk as a whipping-boy, you do not heal the stripes that you have inflicted by congratulating him on his fortitude. Unnatural treatment is made doubly harmful by inconsistency in its application, and the deplorable effects of Western behaviour towards both nationalities are written large on the characters of the present generation. In both cases, the evil that we have done to them exceeds, and will probably outlive, the good.

It is not my intention to minimise the advantages which the Greeks-to consider them first—have derived from Western goodwill. Our sympathy has stimulated their efforts, our charitableness encouraged them to retrieve their mistakes, our exceptional disinterestedness and even generosity towards them has thrown open to them the highest career as a nation for which they may be qualified by their talents. When they took up arms for their independence and began to be worsted in an unequal struggle, Great Britain, France, and Russia agreed on intervention, ${ }^{1}$ and a few months afterwards the power of the Ottoman and Egyptian Governments to carry on the war was broken-'accidentally on

\footnotetext{
${ }^{1}$ Treaty of the $6^{\text {th }}$ July 1827 for the Pacification of Greece.
} 
purpose'-by the Allied fleets at Navarino. ${ }^{1}$ Again, when state organisation had to be provided for the liberated Greek nation, Western statesmen bestowed on Greece, from the outset and on their own initiative, that 'sovereign independence' which they and their successors have always refused (in practice if not in theory) to Turkey. The demand for the realities of this status, formulated in Article 6 of the Turkish National Pact of $1920,{ }^{2}$ has been stigmatized as ridiculous and impertinent. On the other hand, the first point settled in a Protocol signed by the three Powers at London on the $3^{\text {rd }}$ February 1830 was that 'Greece shall form an independent state, and shall enjoy all the political, economic, and commercial rights attaching to complete independence.' Yet, at that date, the Greeks had given no proof of capacity for self-government. They had fought two civil wars before they were half-way through their war against the Turks, squandered their Western loans, and generally ignored their Western advisers. The grant of sovereign independence in these circumstances was an act of faith on the part of Western statesmen, and if it has been justified by the event in Greece, they might be well advised to repeat the experiment for the benefit of Turkey.

At the same time, Greece has, on the whole, received greater injury than advantage from the Western attitude towards her during the first century of her independent existence. The general stimulus to her vitality and the concrete services rendered to her are outweighed by the demoralising effects upon her national character. We have encouraged her to be conceited and pharisaical—to

\footnotetext{
${ }^{1}$ On the $20^{\text {th }}$ October 1827.
} 
over-estimate her own merits and achievements, and to ignore the qualities of the Turk (in spite of the fact that those qualities gave him the dominion over her for four centuries). Taking as their standard of comparison their respective degrees of Westernisation, the Greeks have learnt to regard the Turks as immeasurably their inferiors. They do not realise that their present relative positions, even in this respect, are only temporary; and having staked their fortunes on assimilation to the West, they do not suggest that, in the long run, it may prove no disadvantage to a non-Western people to have remained 'radically alien to Western civilisation.' In national conflicts, it is courting disaster to misconceive the potentialities of an adversary, and the Anatolian campaign, the history of which has been narrated in Chapter VI., is an illustration of the misfortunes which Greece has several times brought upon herself by this error of judgment. But the worst elements introduced into the Greek character by intercourse with the West have been the more impalpable weaknesses of superficiality and lack of originality. Having by our sympathy stimulated the Greeks to make efforts, we have often tempted them to relax them by premature and insincere commendation; and by placing our spiritual heritage unreservedly at their disposal, we have led them to turn their backs upon their own.

Instead of indulging in complacent reflections on their superiority to the Turks, it would be salutary for the Greeks to compare themselves with the Russians-a people of their own Near Eastern civilisation, who came into contact with the West at about the same date as they and under parallel conditions. Why

\footnotetext{
${ }^{2}$ See Text of the Turkish National Pact, pp. 207-10 above.
} 
has Russia made so much more mark than Greece during the last two centuries? Why, in particular, has she had a more momentous and intimate effect upon the destinies of Western society? Her greatness cannot simply be explained by material factors, such as her earlier assertion of her independence against her Middle Eastern conquerors, ${ }^{1}$ or her larger territory, population, and resources. These, of course, account for her military and diplomatic achievements, but not for her contributions to literature and music-spheres in which greatness has no connection with man-power, minerals, armaments or frontiers. The secret of Russia's mental greatness appears to be that she has kept her spiritual individuality. While embracing the West, she has refused to surrender herself to it entirely. This persistent independence of mind (if without first-hand knowledge one may venture an opinion) is the dynamic force in recent Russian history-the source from which both works of genius and 'times of trouble' have come. In politics, its protean presence is discernible in movements of the most opposite complexion. The reactionary Slavophilism of the nineteenth century was a recoil from Westernisation and a harking back towards a mythical 'Golden Age,' before the raw human life of the marshes and forests had received the distinctive impress of any civilisation. Again, the revolutionary Bolshevism of the twentieth century is an enthusiastic acceptance of a condemnation passed by the Western conscience itself upon the structure of Western society. The West was content to put its self-criticism on record. Russia has taken it in earnest, and has

\footnotetext{
${ }^{1}$ The Khans of the 'Golden Horde' (the north-western group of the Mongol Confederacy)
} 
attempted to make it a basis for reconstructing her life on a new non-Western plan. ${ }^{1}$ The same vein of aloofness from the West and repugnance towards it pervasive influence on Russian life has surely been the inspiration of Russian literature. Its uncanny clear-sightedness, its superhuman breadth of vision, its power of objective description and analysis, its melancholy, and the subtle disquietude which it succeeds in communicating even to Western readers, seem traceable to this psychological origin. Nothing could be more different than the genius of this other modern Near Eastern people from the spirit of Modern Greece. What Russia has preserved and created gives the measure of what Greece has lost, or failed to win, and enables us to find a formula for the curse which the West has set upon her. It is spiritual pauperisation.

The Turks have been demoralised in a different way. Certainly we have avoided killing them by kindness, and if it is wholesome for the character never to be flattered or favoured and to be thrown upon one's own resources, we have done them some negative service in this respect. In fact, the Turks have not only had the discipline of 'self-help.' As depositaries of the Caliphate and as the only even quasi-independent Power surviving in the Middle Eastern world, they have been looked up to by the other members of Middle Eastern society, and have had to shoulder some part of their burden in addition to their own immoderate load. This ordeal of acting as bulwarks against Western aggression might have

maintained an effective domination over Russia from A.D. 1238 to 1478.

${ }^{1}$ I must guard myself by mentioning that I regard the Bolshevik régime as a 'time of trouble' and its effects as disastrous. It is one of the destructive manifestations of the Russian attitude towards the West. At the same time, I maintain that, on the balance, that attitude has been more fruitful than the Greek. 
been preferable to being made, like the Greeks, into protégés of the Western intelligentsia, if their Western adversaries had shown chivalry or had even played fair. But unhappily the record of the West in its dealings with Turkey has been not only ungenerous but unscrupulous. This was forcibly illustrated by the attitude of the West in and after 1908, when the Turks tried to throw off their chains as the Greeks had done in 1821. Almost every Western Power took some selfish advantage of the situation. Austria completed her acquisition of Bosnia-Herzegovina by a formal annexation, and persuaded Bulgaria to give her countenance by a simultaneous repudiation of Ottoman suzerainty—both without provocation and in violation of the Treaty of Berlin. Italy, after careful preparation, shamelessly invaded and seized the outlying Ottoman provinces of Tripoli and Benghazi, and thereby gave Turkey's Near Eastern neighbours their long-sought opportunity to fall upon her and take from her almost all her remaining territories in Rumelia. Great Britain, though to her credit she did not attempt at that time to alter the status quo in Egypt, adopted a supercilious if not hostile attitude, or at least (what had the same appearance from the Turkish angle of vision) she permitted such an attitude to be adopted by those who represented her at Constantinople. Germany guilefully assumed the rôle of the friend in need, in order to make Turkey subservient to her designs and to involve her, as it turned out, in their disastrous miscarriage. France alone ${ }^{1}$ can claim the negative distinction of not having rendered herself odious in some way or other to

\footnotetext{
${ }^{1}$ In 1908, Russia was temporarily paralysed by her recent defeat at the hands of Japan, but it
} 
the Turks during the years between the Revolution of 1908 and the European War. This fact, which is generally overlooked in Great Britain, goes far to explain the recent comparative cordiality of Franco-Turkish relations.

But, as in the case of Greece, the concrete actions of Western Powers in war and diplomacy have mattered less, for good or evil, than the overwhelming though imponderable 'suggestion' exercised upon the Turkish by the Western mind. We have injured the Turks most by making them hopeless and embittered. Our skepticism has been so profound and our contempt so vehement, that they have almost ceased to regard it as possible to modify them by their own action. They incline to accept these Western attitudes as fixed stars in their horoscope, with a fatalism which we incorrectly attribute to the teaching of their religion, without realising that our own conduct has been one of its potent causes. But while they are discouraged, they are not deadened to resentment. They see us in a light in which we too seldom look at ourselves, as hypocrites who make selfrighteous professions a cloak for unscrupulous practice; and their mastergrievance against us so fills their minds that it leaves little room for selfexamination. If a charge is brought against them from a Western source, that is almost enough in itself to make them harden their hearts against it, however just it may be. They do not get so far as to consider it on its merits. They plead 'not guilty,' and put themselves in a posture of defence, to meet what experience has led them to regard as one of the most effective strokes in the Western tactic of aggression. In 1921, I seldom found the Turks defend the fearful atrocities which 
they had committed six years previously against the Armenians, but repentance and shame for them were not uppermost in their minds—not, I believe, because they were incapable of these feelings, but because they were preoccupied by indignation at the conduct of the Allied Powers in fomenting a war-after-the-war in Anatolia. Remorse cannot easily co-exist with a grievance, and until we relieve the Turks of the one, we shall certainly fail, as we have done hitherto, to inspire them with the other.

In attempting to express and explain the Turkish point of view, I am not seeking to suggest that it is right, or to deny the charges brought against the Turkish nation and Government for their treatment of subject peoples during the past century. Their crimes are undoubtedly exaggerated in the popular Western denunciations, and the similar crimes committed by Near Eastern Christians in parallel situations are almost always passed over in silence. At the same time, the facts substantiated against the Turks (as well as against their neighbours) by authoritative investigation are so appalling that it is almost a matter of indifference, from the point of view of establishing a case, whether the embroideries of the propagandists are counterfeit or genuine. The point which I wish to make is that, if our aim is not simply to condemn but to cure, we can only modify the conduct of the Turks by altering their frame of mind, and that our only means of doing that is to change our own attitude towards them. So long as we mete out one measure to them, another to the Greeks, and yet a third to ourselves, we shall have no moral influence over them. 
If it be objected that moral influence is not a relevant factor, on the ground that Turkish-speaking Moslems with a nomadic strain in their blood have an innate criminal tendency, it may be answered that there is no logical connection whatever between these linguistic, religious, and economic characteristics on the one hand and a depraved moral constitution on the other, and that the empirical method of injury leads to opposite conclusions. To illustrate this, one has only to compare the Osmanli Turks with the Kazan Tatars, another Turkish-speaking Moslem people descended from a minority of nomad immigrants grafted on to a more numerous sedentary population. The chief physical and cultural difference between the Osmanlis and the Kazanlis is that while the ancestors of the former were mostly Greek-speaking Orthodox Christians with a Near Eastern civilisation, the non-nomadic ancestors of the Kazanlis were uncivilised Finns. Philhellenes are bound to admit that if the moral character of a nation is determined once foro all by race, language, and religion, there are more promising ingredients in the Osmanli compound. In view of this, I commend to their attention the following passages from a British official publication, compiled by a distinguished English scholar: ${ }^{1-}$

'The Volga Turks are, on the whole, distinguished by their sobriety, honesty, thrift, and industry. By their assiduity they often acquire considerable wealth. They live on the best of terms with

\footnotetext{
${ }^{1}$ Manual on the Turanians and Pan-Turanianism, compiled by the Geographical Section, Naval Intelligence Division, Naval Staff, Admiralty (author's name not published): sold by H.M. Stationery Office.
} 
their Russian peasant neighbours. The chief occupation of the Kazan Turk is trade, to which he turns at once when he has acquired a small capital by agriculture. On his commercial journeys he is always a propagandist of Islam. His chief industries are soap-boiling, spinning, and weaving. He is sometimes a worker in gold. He makes a good shoemaker and coachman. ... These Turks are more cleanly in their houses than the Russian peasantry. . . .

'Till the end of the sixteenth century, no mosques were tolerated in Kazan, and the Tatars were compelled to live in a separate quarter. But the predominance of the Moslems gradually prevailed, so that in the second half of the eighteenth century there were as many as 250 mosques in the Government of Kazan. A ukase of tolerance promulgated in $1773^{2}$ helped the cause of Islam among these Turks. Far from being won by Russian tolerance, the Moslems of the Volga have in modern times become more closely united than ever with the Mohammedan world. . . .

'There has been a rapid increase in the number of mosques and a steady improvement in the status of Moslem

\footnotetext{
${ }^{2}$ The date of the Ottoman Government's charter to the Greek community of Aivali (see Chapter IV.). Russian and Turkey, being engaged at the time in a desperate war, each found it advisable to make concessions to subject minorities of the same civilisation as the enemy Power.
} 
schools in the Government of Kazan. ... These schools have not been affected in the least by the Russian educational system. . . .

'In consequence of the attention paid to education, the percentage of Kazan Turks who cannot read and write is extremely low. The production of printed books has also been considerable among these Moslems. . . .

'Thus, during a period of 360 years of Russian rule, the Asiatic conservatism of these Kazan Moslems has in no way been weakened or influenced by Russian culture. ... No conversion except among their ruling families takes place, and only the quite uneducated element is liable to be absorbed in the Russian population. ...'

Take this passage; substitute 'Anatolian Greek' for 'Volga Turk,' 'Osmanli' for 'Russian,' and 'Orthodox Christianity' for 'Islam'; and then read it again, without altering the dates or even omitting the meaningless word 'Asiatic.' You will find in it an accurate summary of the facts and events already discussed in Chapter IV. of this book. The bent for commerce and manufacture, even down to the specialization in soap-making and the carpet-industry; the renascence after several centuries of alien domination; and zeal for education and the rapprochement with more numerous and powerful co-religionists abroad; the imperviousness to the culture of the surrounding majority-feature by feature, with astonishing exactitude, the portrait of the Orthodox Christian minorities in 
Anatolia is reconstructed in this description of the Volga Turks. Confronted with this, can any one any longer maintain that the character of Osmanli and Kazanli Turkish-speaking Moslems, or indeed that of Greek and Russian Orthodox Christians, is determined a priori by their race, language, and religion, and is not the product of the particular political, social, and economic environment in which they happen to find themselves for the time being? There is a legend that male, white-coated, blue-eyed Angora cats are invariably deaf, by a law of nature which has never been fathomed but which always works. I have made no personal investigations, but I venture to submit that if specimens were examined and fifty per cent. of them turned out to be sound of hearing, the legendary hypothesis would have to be discarded.

The unfortunate effect of all these misconceptions upon the life of the Greeks and the Turks would not, however, be a tragedy of any great interest, except for the victims themselves, if our attitude towards them were not a test case of our relations with the great contemporary non-Western societies to which they respectively belong. That is the interest and the danger of the situation. Inveterate prejudices in regard to two minor nationalities, ploughing furrows in Western minds, have not only dug trenches across the fields of Anatolia, but actually threaten to dig the graves of civilisations.

Now that, for good or evil, the living civilisations of the world have come into contact with each other, three alternative possibilities lie before them-a struggle for supremacy, non-co-operation, or the discovery of a modus vivendi. Of these, the struggle for supremacy has unhappily been an element in the 
situation from the beginning. The present dominion of Western Powers over non-Western countries and peoples was in most cases established originally by military conquest; and though Western imperialism has been honourably distinguished by a desire to place its authority on a moral basis, the spirit of the 'dominant race' flares up in us whenever our non-Western subjects cross our wills. It comes out strikingly even in our attitude towards the theoretically sovereign and independent Osmanlis. For example, in approaching the problem of protecting the alien minorities in Turkey, we are tempted to give way to pride at the expense of humanitarianism. We cannot bear that our wishes regarding this or any other matter should be set at defiance by a non-Western Power; and we go on attempting to settle the minorities question by force (often with disastrous consequences to our would-be protégés), because we cannot bring ourselves to negotiate with the Turks as equals, to consider their point of view, or to enlist their goodwill. 'The Turk understands nothing but force.' If true, that is a condemnation of his teachers, for Western diplomacy has given him no reason for believing in anything else. When and how did Turkey succeed in shaking off the galling shackles of the Capitulations? Not in peace-time, and not by the liberal consent of the Western parties to these onerous diplomatic contracts. She shook them off first during the European War, by a unilateral act of denunciation which the Entente Powers could not, in the circumstances, prevent or the Central Powers refuse to sanction. The Capitulations were imposed again immediately after the armistice, and re-embodied in the Treaty of Sèvres. They were shaken off a second time by force of arms in the territories liberated from Allied control by 
the Nationalist Movement. With these precedents, it will need a diplomatic tour de force to transfer the question of the Capitulations, or any other question pending between Turkey and the Western Powers, from the plane of force to the plane of rational negotiation. The same tradition of violence prejudices almost all the relations of the West with non-Western societies, and the reaction of the Turkish Nationalists to it has its parallel in wider anti-Western movements like militant Pan-Islamism. It is unnecessary to point out that if this state of mind prevails it will be disastrous to all parties, but there is some need for Westerners to remind themselves that the main responsibility for banishing it rests upon them. He who takes the sword shall perish by the sword, unless another spirit moves him in time to put up his sword into the sheath and to heal any wound which it may have inflicted.

The second alternative of non-co-operation has recently been preached as a doctrine in India by Mr. Ghandhi and pursued impulsively by the people of the United States. But is it really possible for different societies, when once they have met, to recover their original independence of one another? Even the Americans are not thorough-going in their avoidance of commitments. They have refused a political mandate in the Near and Middle East, but they have not recalled their educationalists and missionaries. ${ }^{1}$ These devoted American

\footnotetext{
${ }^{1}$ When Japan adopted the policy of non-co-operation in the seventeenth century, she was more drastic. In 1636 the Japanese Government 'ordained that no Japanese vessel should go abroad, that no Japanese subject should leave the country, and that, if detected attempting to do so, he should be put to death' (Encyclopedia Britannica, vol. 15, p. 234). The Abyssinians, who expelled all Westerners, neck and crop, from their country within a year or two of their expulsion from
} 
apostles of mental and spiritual union between West and East have been labouring for a century in the Turkish, Syrian, Persian, Indian, and Far Eastern fields, and have received wider support among their distant compatriots at home than the missionaries of any European country (except possibly Scotland). The trader already follows, and he is only late in the field because American industry has hitherto been pre-occupied with the exploitation of its own continent. The exceptional opportunity for internal expansion that has existed in the United States has been the psychological foundation of the 'Monroe Doctrine,' but the vacuum will not continue for ever, and, as soon as it is filled, the economic energies previously attracted into it will be driven to search for foreign outlets. As for the other great industrial countries of the Western world, they have depended on the Middle Eastern, Indian, and Far Eastern markets since the beginning of the Industrial Revolution. Without the mass-demand of non-Western peoples for cotton goods, modern Lancashire (for example) would hardly have come into existence, and it certainly could not continue to support its present population if that demand were brought to an end by Mr. Gandhi's preaching.

From the Western point of view, therefore, non-co-operation involves such economic dislocation that a serious adoption of this policy by the other side might lead us into the fatal course of repression. But, again, is it a strategy which Mr. Ghandhi's countrymen could carry to a conclusion, even if they did not encounter violent forms of opposition? The obvious way, after all, to drive out one nail is time, for it enabled both peoples to preserve their independence unbroken. On the other hand, 
with another. The organisation (as distinct from the mere generation) of a massmovement is itself a characteristically Western idea, and Mr. Ghandhi has used the Western technique of newspaper and conference to translate it into action. His movement, passing as it almost inevitably would from non-violence to the use of force, might conceivably succeed in bringing to an end the military, political, and economic ascendency of a particular Western Power over the territory of India, but the process might very possibly establish the ascendency of Western civilisation over Indian society. The products of the Lancashire factories are surely less likely to be driven out of India by the spinning-wheels and hand-looms which the mahatma commends to his followers, than by similar products of similar factories at Poona. The English civil servant will hardly be relieved of his functions by the Indian guru until the latter has transformed himself from a saint into an administrator; and the transfer of authority will probably be postponed till the day when a native Indian army has sufficiently mastered the Western technique of war to measure itself against the Western army of occupation. The Westerner might go, but his works would remain, and the Indian—labouring ten hours a day in order to supply wants learnt from the West by tending Western machinery, spending perhaps three years of his life in compulsory military service, and making the other sacrifices of happiness demanded from human beings by the Western system of society—might find that in order to liberate his body he had given the West dominion over his soul. In other words, the policy of non-co-operation is not likely to attain or even to approach its goal. If carried to 
any lengths, it would merely revive the struggle for supremacy and reverse the rôles of the antagonists. As the process worked itself out, the material and therefore comparatively superficial ascendency previously exercised by Western Powers would be wrested from them by the subject populations, but Western civilisation would invade and subjugate the inner life of non-Western societies to a degree which might not have been possible when it was working through a handful of Western conquerors, and not through the hearts and minds and daily habits of the conquered peoples. Such a result might delight Mr. Thomas Hardy's Spirit Ironic, for it would be just as disastrous as that of open war. A positive modus vivendi is the only escape from these other alternatives, and the task of finding one must principally devolve upon the West. At the moment, ours is the greatest civilisation in the world, and though our superiority may be temporary, it imposes obligations on us so long as it lasts. By our exuberant vitality, if by no finer qualities, we have profoundly affected the development of other societies, deflected them from their course, and set forces in motion within them which may not only transform their characters but may react perilously upon ours. It is thus our interest as well as our duty to forecast and if possible avert these dangers by laying the foundations of a wider society, in which the several great societies now existing may take their place as members, and so contrive to live side by side without bringing one another to destruction. The material problems connected with this task need not cause us anxiety. World-systems of finance, commerce, and transport have been created 
already by the Western genius, and it is not beyond our wit to plan the political machinery for an all-inclusive League of Nations. The test of our greatness will be our success in creating the necessary mental atmosphere-that charity between members of different civilisations, without which it profiteth nothing to have the gift of prophecy and to understand all mysteries and all knowledge.

If the right moral has been drawn in this book from the events with which it deals, such charity can only be imported into our unhappy contemporary relationships by a combination of the two principles of reciprocity and individuality. Their combination is the essential condition, for the failure of our differential treatment of the Greeks and Turks demonstrates the inadequacy of either principle in isolation from the other. It needs little virtue, indeed, to give a seat at our banquet to the stranger who has obligingly put on our wedding garment; or, again, to tolerate his companion's outlandish costume, if we keep him in outer darkness as a penalty for his obstinacy in refusing to change it. True charity means sitting at the same board without formalities or conditions, and taking pleasure in the differences as well as in the likenesses between ourselves and our fellow human beings.

At present, these differences are a stumbling-block. The non-Western societies are oppressed by our chilly shadow, while we are resentful when they assert their individuality. This is partly what arouses our animus against the Turks and the Russians. They do not fit into our Western scheme, and so it bothers us to be reminded of their existence. At the same time, our lack of interest in them, to which attention has been drawn repeatedly in the preceding 
chapters, is probably a sign of well-being in our own society. So long as a civilisation is fulfilling its potentialities and developing in accordance with its genius, it is a universe in itself. Impressions from outside distract it without bringing it inspiration, and it therefore excludes them as far as possible from its consciousness. But no civilisation has yet found the secret of eternal youth, still less of immortality. Sooner or later, they are each overtaken by some irreparable catastrophe, which not only cuts short their growth but strangely transmutes their essence. The steel, formerly so clear and hard, becomes soft and rusty. It is a tragic transformation. Yet this rust, which in the craftsman's eyes is a foul accretion, is revealed to the scientific vision as a subtle compound, in which unlike elements, miraculously blended, acquire properties foreign to each of them before their union.

'When thou wast young, thou girdedst thyself, and walkedst whither thou wouldest; but when thou shalt be old, thou shalt stretch forth thy hands, and another shall gird thee, and carry thee whither thou wouldest not.' For a living creature, the supreme agony is to be caught thus on the wheel of circumstance. Yet no man liveth to himself and no man dieth to himself, and the power which girds and carries whither they would not the civilisations whose creative force is spent, is nature herself. She will not suffer any of her creatures to pass out of existence until they have reproduced their kind, and higher organisms cannot do this except by intercourse with one another. For this reason, no society is ever able to hold itself permanently aloof from its contemporaries. Our spiritual ancestors the Ancient Greeks, in whom Hellenic civilisation had been incarnated, 
believed, in the pride of their youth, that they were of a different clay from the Ancient Orientals. They would have been incredulous if it had been prophesied to them in the fifth century before Christ that nature would one day bring them together in order to bring us, their descendants, to birth. Yet the century which carried them to the pinnacle of their greatness quickly struck them down by the catastrophe of the Peloponnesian War. From that time forward they walked no longer whither they would. They stretched forth their hands to grope after a fellowship which they did not suspect, and from which, they had divined it, they would still have recoiled in surprise. Their Oriental contemporaries understood the course of nature more clearly than they did, and the last act of their tragedy was foretold to them, rather less than five centuries after the outbreak of the fatal conflict between Athens and Sparta, by a Hellenised Jew from a cosmopolitan town in Cilicia.

'Then Paul stood in the midst of Mars' hill, and said, "Ye men of Athens, I perceive that in all things ye are too superstitious. For as I passed by, and beheld your devotions, I found an altar with this inscription, TO THE UNKNOWN GOD. Whom therefore ye ignorantly worship, him declare I unto you.

"God that made the world and all things therein, seeing that he is Lord of heaven and earth, dwelleth not in temples made with hands; neither is worshipped with men's hands, as though he needed anything, seeing he giveth to all life, and breath, and all things; and hath made of one blood all 
nations of men for to dwell on all the face of the earth, and hath determined the times before appointed, and the bounds of their habitation; that they should seek the Lord, if haply they might feel after him, and find him, though he be not far from every one of us; for in him we live, and move, and have our being; as certain also of your own poets have said, For we are also his offspring."'

\section{TABLE OF DATES}

1914 November 5 Great Britain declared war on Turkey.

1915 October 1 Allied officers arrived at Salonika to arrange for the landing of an expeditionary force.

" " $\quad 3 \quad$ Russian ultimatum to Bulgaria. 


\begin{tabular}{|c|c|c|c|}
\hline "“ & “ & 5 & Allied diplomatic representatives left Sofia. \\
\hline “ & " & 5 & $\begin{array}{l}\text { King Constantine received and accepted Mr. } \\
\text { Venizelo's resignation. }\end{array}$ \\
\hline 1916 & April & 10 & $\begin{array}{l}\text { The Allied Powers informed the Greek } \\
\text { Government of their intention to } \\
\text { establish naval bases on Greek islands } \\
\text { in the Aegean. }\end{array}$ \\
\hline “ & August & $30(?)$ & National Defence Movement started at Salonika. \\
\hline “ & September & 25 & Mr. Venizelos left Athens for Krete \\
\hline “ & October & 9 & $\begin{array}{l}\text { Mr. Venizelos arrived at Salonika and formed a } \\
\text { provisional government. }\end{array}$ \\
\hline “ & December & $1-2$ & $\begin{array}{l}\text { Action between Greek and Allied troops at Athens, } \\
\text { followed by the imposition of the blockade } \\
\text { upon Greek territories under the Royal } \\
\text { Government's control. }\end{array}$ \\
\hline 1917 & June & 11 & $\begin{array}{l}\text { Ultimatum presented by M. Jonnart, High } \\
\text { Commissioner of the Allied Powers, to King } \\
\text { Constantine's Government in Athens. }\end{array}$ \\
\hline “ & " & 14 & King Constantine left Greece \\
\hline “ & “ & 25 & $\begin{array}{l}\text { Mr. Venizelos returned to Athens, escorted by a } \\
\text { French expeditionary forces, from Salonika. }\end{array}$ \\
\hline “ & “ & 27 & $\begin{array}{l}\text { Mr. Venizelos formed a new Government at Athens, } \\
\text { which formally intervened in the War on the }\end{array}$ \\
\hline
\end{tabular}


side of the Allies.

1918 October $30 \quad$ Turkey concluded an armistice with the Allies.

1919 March $29 \quad$ Italian troops landed at Adalia.

" April $24 \quad$ Signor Orlando left Paris for Rome; the Italian

Delegation officially suspended its participation in the Peace Conference.

“ May

5 Signor Orlando left Rome for Paris again, but the deadlock over the Adriatic Question continued.

" 15 GREEK TROOPS LANDED AT SMYRNA.

“

21 Mr. Sterghiádhis arrived at Smyrna.

“ By end of May

Greek forces had occupied Manysa and Aidin, and Italian forces Scala Nuova.

“ June

17 Ottoman Delegation (Damad Ferid Pasha, Tewfik

Pasha, and Riza Twefik Bey) stated their case before the Council of Ten at Pais.

1919 June

26 Text of the Council of Ten's Reply published.

“ July

5 British War Office, in an official communiqué, attributed a Kurdish rising at Suleimanie to the instigation of Turkish agitators.

11 Mustafa Kemal Pasha outlawed by the Ottoman Government of Constantinople. 
" "

4

“

August $24 \quad$ First sitting of the Commission of Inquiry sent to Smyrna by the Governments of the Principal Allied Powers and the United States.

“ September 13 October 5 Damad Ferid Ministry at Constantinople replaced by an Ali Riza Ministry, with a mandate from the Sultan to hold a general election.

" 7 Mustafa Kemal Pasha telegraphed to the Ottoman Government the peace-terms formulated at the Congresses of Erzerum and Sivas.

“ November

4

Aintab taken over by French forces from the British; withdrawal of British forces from the Taurus begun.

“ Deember 10

British War Office announced the completion of the withdrawal of the British forces from Cilicia and Syria to the south side of the Palestine frontier.

1920 January 11 Session of the Ottoman Parliament began at Constantinople. 
"4

6

" "

“

“

February

“

19

19 The Circassian chetté-leader Anzavur Bey drove the Nationalist forces out of Bigha.

26 Debate in the House of Commons at Westminster on the future of Constantinople.

“ March

“ “

15 Prominent Turks at Constantinople arrested during the night by British officers and deported to Malta.

16 In the House of Commons, Mr. Lloyd George refused to publish the report of the Smyrna Commission of Inquiry. 
16 Naval and military occupation of Constantinople by the Allied Powers and simultaneous recall of the Allied control-officers from the interior of Anatolia.

“ “

“ “

“ By April April

“

“ $\quad$ “

(1)


Riza Ministry, all denouncing the Nationalist Movement.

" "

" "

" 6

"By end of April

“ April

24(?) Turkish Great National Assembly met at Angora and set up a Government.

“ Before end of Aprili (?) Military convention concluded by the Governments of Angora and Moscow.

“ May

6 Peace Delegation of the Constantinople Government arrived at Paris.

11 Draft of the Peace Treaty handed to the Constantinople Delegates.

"

12 Draft of the Peace Treaty published in the British Press.

28(?) French garrison of Bozanty taken prisoner by Turkish Nationalist forces, while attempting to retreat to the coast.

30(?) Armistice arranged between the French and Turkish forces in Cilicia. (N.B. This broke down within a fortnight.) 
" By end of May

“ June

1920 June

“

"

6

Nationalist forces had occupied Adapazar and Yalova.

3 Albanians attacked the Italian garrison of Avlona after delivering an ultimatum (see Times of $31^{\text {st }}$ July 1920); Italian railwaymen and seamen refused to handle munitions for the Albanian War.

11 Mutiny of Italian troops at Trieste when ordered to embark for Albania.

15 Turkish Nationalist forces attacked the British Indian garrison of Ismid.

Conference between Mr. Venizelos and Mr. Lloyd George at No. 10 Downing Street.

Conference at Hythe (Present: Mr. Lloyd George, M. Millerand, Mr. Venizelos, Marshal Foch, General Weygand, Field-Marshal Sir Henry Wilson).

20 All British naval units in the Mediterranean ordered to Constantinople.

21-2 Conference of Allied Powers at Boulogne.

22 Mr. Venizelos announced to the Press that the Boulogne Conference had sanctioned military action by Greece in Anatolia. 


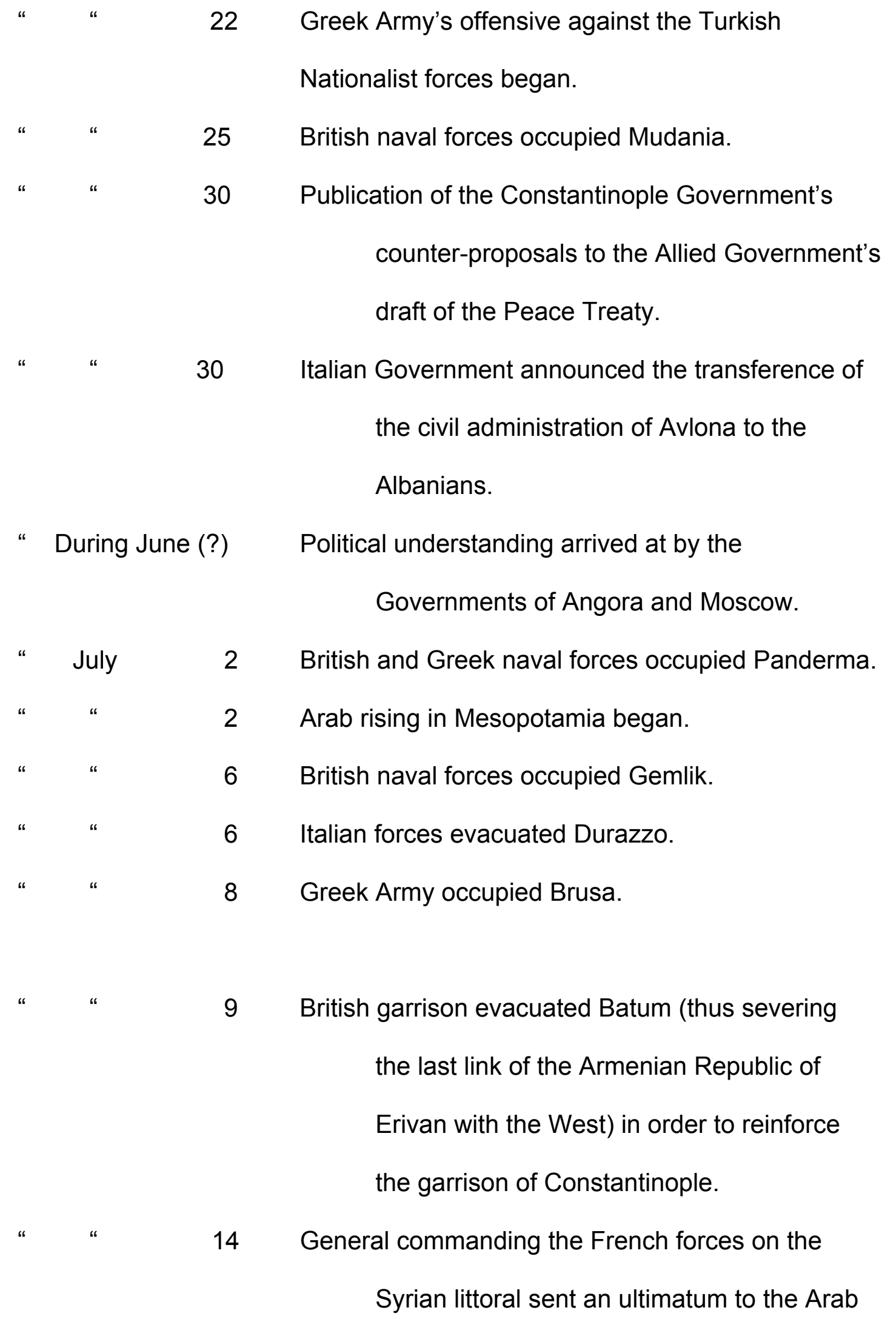


National Government of Damascus.

"

"

"

"

“

“

“ August

1920 August

15 French forces invaded the territory of the Arab

National Government.

20 Greek and British forces occupied Rodosto.

23 French forces occupied Aleppo.

25 Greek forces occupied Adrianople, taking Ja'far

Tayar Bey prisoner.

25 French forces occupied Damascus and overthrew

the Arab National Government.

3 Agreement signed by the Italian and Albanian

Governments, assigning Avlona to Albania

and the island of Saseno to Italy.

10 Signature at Sèvres of (i) Treaty of Peace between

the Allies and Turkey; (ii) Tripartite Treaty

between Great Britain, France, and Italy

regarding Anatolia; (iii) Treaty between

Greece and the Principal Allied Powers

regarding minorities; (iv) Treaty between

the Armenian Representatives and the

Principal Allied Powers regarding

minorities; (v) Protocol between Greece and

Italy regarding Rhodes and the Dodekanese.

29 Greek Army occupied Ushaq. 
“ September 5(?) Last Italian troops left Avlona.

“

17 India Office announced that Sir Percy Cox was being sent to Mesopotamia with the mission of setting up an Arab State there.

"Before end of September Turkish Nationalist forces under Kiazym Kara Bekir Pasha invaded the Armenian Republic of Erivan.

" October 15 Fall of the Armenian town of Hajin in the Cilician Highlands, and massacre of the inhabitants by Turkish Nationalist forces.

" 4

17 Soviet Government of Moscow sent an ultimatum to the Republic of Erivan.

“

20 British War Office announced the completion of the principal operations for the re-establishment of British military control in Mesopotamia.

25 Death of King Alexander of Greece.

31 Soviet forces broke through General Wrangel's lines at Perekop.

“ November 2 Kiazym Kara Bekir's forces captured Kars.

14 General Election in Greece.

14 General Wrangel's Army evacuated Sebastopol.

16 General Wrangel's Army arrived at Constantinople. 
“

“

December

2

17 Mr. Venizelos resigned office.

Overthrow of the Dashnakist Government and establishment of a Soviet Government at Erivan.

4 Ultimatum from the Government of Moscow to the Turkish Nationalists, forbidding them to advance further into Armenian territory; followed within a few days by signature of peace between the Governments of Angora and Erivan.

" “

5 Plebiscite held in Greece on the question of the recall of King Constantine.

19 King Constantine arrived at Athens.

" By end of December The last tribes had capitulated to the British forces in Mesopotamia.

1921 January 9 Greek reconnaissance in force from Brusa to In Önü.

" February 21 Conference of the Allied Powers at London, attended by Delegations from the Governments of Athens, Constantinople, and Angora.

“ March $12 \quad$ Conference of London terminated.

1921 March 16 Treaty signed at Moscow by the Governments 
of Moscow and Angora.

23 Greek Spring Offensive began.

" April 4 Greek Spring Offensive terminated.

"Middle of April Greek organised atrocities began.

“ May 18 Proclamation of neutrality and designation of a

neutral zone by the three Allied High

Commissioners at Constantinople.

"Beginning of June Turkish organised atrocities began.

“ June $21 \quad$ British Government invited the Greek Government to accept the mediation of the Allies.

" "

25 Semi-official summary published at Athens of the

Greek Government's note declining mediation.

“ “ 25-30

Greek forces evacuated the Ismid enclave and the Yalova Peninsula.

“ July $\quad 10 \quad$ Greek Summer Offensive began.

“ " $\quad 17 \quad$ Greek Army captured Kiutabia.

“

19 Greek Army captured Eski Shehir.

21 Turkish counter-attack against the Greek Army east of Eski Shehir failed.

“ August $14 \quad$ Greek Army began a fresh advance eastwards.

" " 24

24 Greek Army began a general offensive against the new Turkish positions on the Sakkaria and the 
Gök Su.

“ September 8 Turkish counter-attacks began.

" " $\quad$ 12-13 Greek Army recrossed the Sakkaria.

" " $16 \quad$ Withdrawal of the Greek Army began.

“

23 Greek Army halted at its previous positions covering

Eski Shehir.

" October 13 Treaty signed at Kars by the Governments of Angora

and of the three Transcaucasian Soviet

Republics.

20 Agreement signed at Angora by M. Franklin-Bouillon and Yusuf Kemal Bey.

1922 March 22 British, French, and Italian Foreign Ministers met in Conference at Paris and proposed an armistice in the Graeco-Turkish War, on the basis of the evacuation of Anatolia by the Greek Army.

"

26 British, French, and Italian Foreign Ministers communicated proposals for a peacesettlement to the Government of Athens, Constantinople, and Angora. 


\section{LIST OF BOOKS ${ }^{1}$}

\footnotetext{
${ }^{1}$ This list is neither called, nor intended as, a bibliography. It is simply a summary guide to further information about various questions discussed or referred to in the text of this book. Original authorities are seldom mentioned, except for the events of 1921. A catalogue of them would fill a volume by itself. I have marked with an asterisk* the references which I have not been able to verify.
} 


\section{CHAPTER I}

(i) Rise and Break-down of Near Eastern Civilisation (pp. 5-7).

DIEHL, CH.: 'Byzance, Grandeur et Décadence.' (Paris, 1919, Flammarion.)

DIEHL, CH.: 'Histoire de l'Empire Byzantin.' (Paris, 1919, Picard.)

GELZER, H.: 'Byzantinische Kulturgeschichte.' (Tübingen, 1909, Mohr.)

GRENIER, P.: 'L’Empire Byzantin, son Évolution Sociale et Politique.' (2 vols., Paris, 1904.)

HESSELING, D. C.: 'Essai sur la Civilisation Byzantine.' (French translation from the Dutch, Paris, 1907.)

JORGA, N.: 'The Byzantine Empire.' (London, 1907, Dent.)

NEUMANN, C.: 'Weltstellung des byzantinischen Reiches vor den Kreuzzügen.' (Leipzig, 1894, Duncker \& Humblot.)

RAMBAUD, A.: 'Etudes sur l'Histoire Byzantine.' (Paris, 1919, Colin.) [Contains a study of the Hundred Years' War between the East Roman Empire and Bulgaria.]

'VASIL'EV, A. A.: 'History of the Byzantine Empire.' (Vol. i. down to 1081, Petrograd, 1917.) [In Russian.]

ZLATARSKI, V. N.<SLATARSKI, W. N.>: 'Geschichte Bulgariens 679-1396’ = Bulgarische Bibliothek, no. 5, vol. i. (Leipzig, 1918.)

(ii) Rise and Break-down of Middle Eastern Civilisation (pp. 9-12).

GIBBONS, H. A.: 'The Foundation of the Ottoman Empire, 1300-1403.' (Oxford, 1916, Clarendon Press.) 
HAMMER, J. VON: 'Des osmanischen Reichs Staatsverfassung and Staatsverwaltung.' (2 parts, Vienna, 1815.) [Documented.] HAMMER < -- PURGSTALL>, J. VON: 'Geschichte des osmanischen Reiches.' (10 vols., Pest and Vienna, 1827-35; 4 vols., Pest, 1835-6; French translation, 18 vols. [and atlas], Paris, 1835-43.

JORGA, N.: 'Geschichte des osmanischen Reiches.' (First 4 vols. down to 1774, Gotha, 1908-11, Perthes.)

KOJA (or KUJY) BEG: 'Abhandlung über den Verfall des Osmanischen Staatsgebäudes seit Sultan Suleiman dem Grossen,' German translation by W.F. A. Behrnauer in Z.D.M.G., xv. pp. 277-332. (Leipzig, 1861, Brockhaus.)

LANE-POOLE, S.: 'Mediaeval India, 712-1764'=Stories of the Nations Series. (London, 1903, Fisher Unwin.)

LYBYER, A. H.: 'The Government of the Ottoman Empire in the Time of Suleiman the Magnificent'=Harvard Historical Studies, xviii. (Cambridge, Mass., 1913, University Press.)

MORELAND, W.H.: 'India at the Death of Akbar: An Economic Study.' (London, 1920, Macmillan.)

OWEN, S.J.: 'The Fall of the Mogul Empire.' (London, 1912, Murray.)

RYCAUT, Sir P.: 'The Present State of the Ottoman Empire.' (London, 1668 ${ }^{1}$.) 
TISCHENDORF, P. A.: 'Das Lehnwesen in den moslemischen Staaten, insbesondere im osmanischen Reiche, mit dem Gesetzbuche der Lehen unter Sultan Ahmed I.' (Leipzig, 1872.)

(iii) Westernisation of the Modern Greeks (pp. 7-9).

ANON.: 'Perì tìs en Dhimitsáni Ellinikìs Skholis ke perì ton kathidhritòn ke proton aftìs dhidhaskálon.' <'The Greek School of Dhimitsana, its Founders and First Teachers.'> (Athens, 1847, Koromilas.) [In Greek.]

BLANCARD, TH.: 'Les Mavroyéni.' (Paris, no date, Flammarion.)

CHASSIOTIS, G.: 'L'Instruction Publique chez les Grecs dupuis la Prise de Constantinople par les Tures jusqu'à nos jours.' (Paris, 1881, Leroux.) KOLOKOTRÓNIS, TH.: 'Dhiíyisis Symbándon tìs Ellinikis Phylís, 1770-1836.' (Athens, $1889^{2}$, Estía.) [In Greek.]

LUNZI, E.: 'Storia della Isole lonie sotto il Reggimento dei Reppublicani Francesi.' (Venice, 1860.)

MENDELSSOHN-BARTHOLDY, K.: 'Graf Johann Kapodistrias, mit Benutzung handschriftlichen Materials.' (Berlin, 1864.)

NEROULOS, J. R., ancien premier ministre des hospodars grecs de Valachie et de Moldavie: 'Histoire de l'Insurrection Grecque, précédée d'un précis d'Histoire Moderne de la Grèce.' (Paris and Geneva, 1834.) 
PHOTAKOS $<=$ PH. KHRYSANTHÓPULOS, principal aide-de-camp to Theodore Kolokotrónis>: 'Memoirs.' (2 vols., Athens, 1899, Sakellários.) [In Greek.] *STAMATIÁDHIS, E. I.: 'Vioghraphíe ton Ellínon Meghálon Dhierminéon.' <'Biographies of the Greek Grand Dragomans.'> (Athens, 1865.) [In Greek.]

(iv) Cyril Lukaris (p. 8).

LUKARIS, KYRILLOS, OECUMENICAL PATRIARCH: 'Omoloyía tis Khristianikis Písteos: Confessio Christianae Fidei.' (Geneva, 1633.) [Greek and Latin parallel versions.]

METTETAL, A.: 'Études Historiques sur le Patriarche Cyrille Lucar.' (Strassburg, 1869.)

PICHLER, A.: 'Geschichte des Protestantismus in der orientalischen Kirche im 17 Jahrhundert.' (Munich, 1862.)

RENIÉRIS, M.: 'Kýrillos Lúkaris, o ikumenikòs Patriárkhis.' (Athens, 1859, Mavrommátis.) [In Greek.]

SMITH, THOMAS: 'Miscellanea, in quibus continentur . . . brevis et succincta narratio de vita, studiis, gestis et martyrio D. Cyrilli Lucarii, Patriarchae Constantinopolitani ...' (Lond, 1686.)

(v) Westernisation of Osmanli Turks (pp. 12-14). 
AHMED EMIN: 'The Development of Modern Turkey as measured by its Press'=Columbia Studies in History, Economics, and Public Law, lix. (142). (New York, 1914.)

CAUSSIN DE PERCEVAL, A. P.: 'Précis Historique de la Destruction du Corps des Janissaires (1826), traduit du turc.' (Paris, 1833, Didot.)

DE CHÉNIER, L.: 'Les Révolutions de l'Empire Ottoman.' (Paris, 1789.)

DE JUCHEREAU DE ST. DENYS, A.: 'Les Révolutions de Constantinople en 1807 et 1808.' (2 vols., Paris, 1819.)

JORGA, N.: 'Geschichte des Osmanischen Reiches.' (Vol. v., 1774-1912, Gotha, 1913, Perthes.)

MANDELSTAM, A.: 'Le Sort de l'Empire Ottoman.' (Lausanne \& Paris, 1917, Payot.)

MIDHAT, A. H.: 'Life of Midhat Pasha.' (London, 1903, Murray; Paris, 1908 [in French]; Constantinople, 1909 [in Turkish].)

MOLTKE, H. K. B. VON: 'Briefe über Zustände und Begebenheiten in der Türkei, 1835-9.' (Berlin, 1875; 1911, Mittler.)

MUHAMMAD AS AD SAFVAT. See Caussin de Perceval, A. P.

OTTOMAN LAW of the $12^{\text {th }}$ March 1917 , by which all ecclesiastical courts and the official connected with them were placed under the authority of the Ministry of Justice. (Official text in the Takvym-i-Vak'ý (Gazette) of the Ottoman Empire, No. 2840; German translation in the Neuer Orient of Berlin, $15^{\text {th }}$ September 1917, p. 546.)

PEARS, SIR E.: 'Abdu'I-Hamid.' (London, 1917, Constable.) 
POULGY, G.: 'Les Emprunts de l'État Ottoman.' (Paris, 1916.)

UBICINI, J. H. A.: 'Lettres sur la Turquie, ou Tableau Statistique ... depuis le Khatti-chérif de Gulkhané, 1839.' (2 vols., Paris, 1853-4².)

URQUHART, D.: 'The Spirit of the East.' (2 vols., London, 1838.)

YOUNG, G.: 'Corps de Droit Ottoman.' (7 vols., Oxford, 1905-6, Clarendon Press.)

(vi) Mutual Influence of Ancient Hellenic and Oriental Civilisations (p. 22).

BEVAN, E. R.: 'The House of Seleucus.' (2 vols., London, 1902, E. Arnold.) BOUCHÉ-LECLERCQ, A.: 'Histoire des Seleucides.' (2 parts, Paris, 1913.) CUMONT, FR.: 'Les Religions Orientales dans le Paganisme Romain'=Musée Guimet, Annales, Bibliothèque de Vulgarisation, vol. xxiv. (Paris, 1906.) FERGUSON, W. S.: 'Greek Imperialism.' (London, 1913, Constable.) HARNACK, A. VON: 'Mission und Ausbreitung des Christentums in den ersten drei Jahrhunderten.' (Leipzig, 1906²; English translation, 2 vols., London $1908^{2}$, Williams \& Norgate.)

LAKE, KIRSOPP: 'Landmarks in the History of Early Christianity.' (London, 1920, Macmillan.) 
MOMMSEN, TH.: 'The Provinces of the Roman Empire.' (Vol. ii. of English translation, London, 1886, Bentley.)

REITZENSTEIN, R.: 'Die Hellenistischen Mysterienreligionen.' (Leipzig and Berlin, 1910, Teubner.)

WENDLAND, P.: 'Die Hellenistisch-Römische Kultur in ihren Beziehungen zu Judentum und Christentum.' (Tübingen, $1912^{2}$ und $^{3}$, Mohr.)

(vii) Relations between the Russian Soviet and the Turkish Nationalist Governments (pp. 23-24).

RANSOME, ARTHUR: 7 articles on 'Russian Policy in the East,' dispatched from Reval $4^{\text {th }}-9^{\text {th }}$ July 1921 , and published in the Manchester Guardian $12^{\text {th }}-$ $22^{\text {nd }}$ July 1921.

(viii) Spread of Western Political Nationalism in the Near and Middle East (pp. 15-18).

BRAILSFORD, H. N.: 'Macedonia, its Races and their Future.' (London 1906, Methuen.) [With Maps.]

'DIPLOMATIST': 'Naitonalism and War in the Near East.' (Oxford, 1915, Clarendon Press.)

DURHAM, M. E.: 'Twenty Years of the Balkan Tangle.' (London, 1920, G. Allen and Unwin.) 
SETON-WATSON, R. W.: 'The Rise of Nationality in the Balkans.' (London, 1917, Constable.) [With Maps.]

'TEKIN ALP' <==Cohen, Albert>: 'Türkismus und Pan-Türkismus.' (Weimar, 1915, Kiepenheuer.)

"VARANDIAN, M.: 'Les Origines du Mouvement Arménian.' (2 vols., Geneva, 1913, Fédération Révolutionnaire Arménienne.)

(ix) The 'Language Question' in Greece (pp. 20-21).

GREEK MINISTRY OF CULTS AND PUBLIC INSTRUCTION: Bulletin, Supplement 3: 'Language-Teaching in the First Three Classes of the National Schools.' (Athens, 1919.) [In Greek.]

GREEK MINISTRY OF CULTS AND PUBLIC INSTRUCTION: Bulletin, Supplement 5: 'Language-Teaching in the Fourth Class of the National Schools.' (Athens, 1920.) [In Greek.]

KHATZIDHÁKIS, G. N., \& KRUMBACHER, K.: ‘To Próvlima tis Neotéras ghraphoménis Ellinikís, ypò K. Krumbacher; ke apándisis is aftòn, ypò G. N. Khatzidhákis < The Problem of Modern Written Greek, by K. Krumbacher; and a reply to him, by G. N. Khatzidhákis>.' (Athens, 1905, Sakellarios.)

KRUMBACHER, K.: 'Das Problem der neugriechischen Schriftsprache.' (Munich, 1903, Verlag der K. B. Ak. Wiss.) [German original of first part of Khatzidhákis, cited above.] 
PALLIS, A.: 'Iliádha.' (Paris, 1904, Chaponet; Liverpool, 1917, 'Liverpool Booksellers.') [Translation of the Iliad into popular Modern Greek.]

PALLIS, A.: 'I Néa Dhiathíki katà to Vatikáno Kheróghrapho Metaphrasméni.' (Liverpool, 1910², 'Liverpool Booksellers.') [The New Testament in popular Modern Greek.]

PHOTIÁDHIS, Ph. Dh.: 'To Ghlossikòn Zitima k’ I Ekpedheftikí mas Anayénnisis <The Language Question and our Educational Resurrection>.' (Athens, 1902, 'Estía’ Press.)

PSICHARI, JEAN: Works, 1901-13. (Paris, Welter; Athens, 'Estía' Press.) [Mr. Psichari's ambition is to make Modern Greek into a vehicle for the ideas of Western civilisation without having recourse to Ancient Greek morphology and syntax. He draws upon the Ancient vocabulary, but transposes the words he borrows into Modern forms.]

ROÏDHIS, E. Dh.: 'Ídhola: Ghlossikì Meléti.' (Athens, 1893, 'Estía’ Press.)

TRIANDAPHYLLÍDHIS, M.: 'Prin káun: I Alíthia ya t' Anaghnostikà tis Dhimotikís.' (Athens, 1921, 'Estía' Press.)

YANÍDHIS, E. ': 'Ghlóssa ke Zoï: Analytikì Meléti tu Ghlossikù Zitímatos Language and Life: An Analytical Study of the Language Question>.' Athens, $1914^{3}$, 'Estía' Press.)

\footnotetext{
${ }^{1}$ Spelt 'Gianídhis' in the Greek script.
} 
(x) The 'Caliphate Question' in the Moslem World (pp. 28-32).

AMER ALI, Right Hon. SYED: 'The Caliphate: A Historical and Juridical Sketch.' Contemporary Review, June 1915.)

BARTHOLD, W.: 'Studien über Khalif und Sultan.' (Der Islam, Band vi.)

*DAVENPORT, J.: 'Essay upon the Caliphate.' (Calcutta, 1884.)

INDIAN KHILAFAT DELEGATION (1920): ‘1. The Turkish Settlement and the Indian Muslim Attitude.' (London, 1920.) [Address presented to the Viceroy at Delhi on the $19^{\text {th }}$ January 1920 and Manifesto of the All-India Khilafat Conference passed at the Session of the $15^{\text {th }}-17^{\text {th }}$ February at Bombay.]

INDIAN KHILAFAT DELEGATION (1920): '2. The Secretary of State for India and the Indian Khilafat Delegation.' (London, 1920.) [Report of an interview with the Right Hon. H. A. L. Fisher, acting on behalf of the Secretary of State, on the $2^{\text {nd }}$ March 1920.]

INDIAN KHILAFAT DELEGATION (1920): ‘3. The Prime Minister and the Indian Khilafat Delegation.' (London, 1920.) [Minutes of Proceedings at a Deputation to the Prime Minister on the $19^{\text {th }}$ March 1920.]

LANE-POOLE, S.: 'The Caliphate.' (Quarterly Review, July 1915.)

MARGOLIOUTH, D. S.: 'The Caliphate.' (New Europe, vol. xiv., no. 182 of the $8^{\text {th }}$ April 1920.)

NALLINO, C. A.: 'Appunti sulla Natura del Califfato in Genere, e sul presunto Caaliffato Ottomano.' (Rome, 1917.) 
TOYNBEE, A. J.: 'The Question of the Caliphate.' (Contemporary Review, February 1920.)

\section{CHAPTER II}

(i) Empires of Mediaeval Western Powers in the Levant (pp. 37-38).

ANDREÁDHIS, A. M.: 'Perì tis Ikonomikìs dhiikíseos tis Eptanísu epi

Venetokratías.' (2 vols., Athens, 1914, Estía.) [In Greek.]

BROWN, H. F.: 'The Venetians and the Venetian Quarter in Constantinople to the Close of the Twelfth Century.' (Journal of Hellenic Studies, vol. xl., pt. 1, 1920.)

DE MAS LATRIE, J. M. J. L.: 'Privilèges Commerciaux accordés à la République de Venise par les Princes de Crimée et les Empereurs Mongols de Kiptchak.' (Paris, 1868, École des Chartes, Série VI., vol. iv., p. 580.)

FOTHERINGHAM, J. K. and WILLIAMS, L. F. R.: 'Marco Sanudo, Conqueror of the Archipelago.' (Oxford, 1915, Clarendon Press.)

HEYD, W.: 'Colonie Commerciali degli Italiani in Oriente nel Medio Evo.' (Italian translation, 2 vols., Venice, 1866-8, Antonelli.)

HEYD, W.: 'Geschichte des Levantehandels im Mittelalter.' (2 vols., Stuttgart, 1879; French translation by P. Raynaud, 2 vols., Leipzig and Dessau, 1885-6.)

HOPF, K.: 'Les Giustiniani Dynastes de Chios.' (French translation, Paris, 1888, eroux.) 
JEGENLEHNER, J.: 'Beiträge zur Verwaltungsgeschichte Kandias im 14 ten ahrhundert.' (Byzantinische Zeitschrift, xiii., 1904.)

LUNZI, E.: 'Della Condizione Politica delle Isole Ionie sotto il Dominio Veneto.' Venice, 1858; Greek original, Athens, 1856, Philadhelphéfs.)

MILLER, W.: 'Essays on the Latin Orient.' (Cambridge, 1921, University Press.) Specially interesting on the Genoese.]

MILLER, W.: 'The Latin Orient'=Helps for Students of History, No. 37. (London, 1920, S. P. C. K.)

MILLER, W.: 'The Latinis in the Levant.' (London, 1908, Murray.)

PAGANO, C.: 'Delle Imprese e del Dominio dei Genovesi nella Grecia Libri iv.' (Genoa, 1846.)

SAULI, L.: 'Della Colonia dei Genovesi in Galata.' (2 vols. Turin, 1831, Bocca.)

SCHAUBE, A.: 'Handelsgeschichte der romanischen Völker des

Mittelmeergebiets bis zum Ende der Kreuzzüge.' (Munich and Berlin, 1906, Oldenbourg.)

TANFANI CENTOFANTI, L.: 'Niccolò Acciajuoli.' (Florence, 1863.)

(ii) Anglo-French Rivalry in the Levant (pp. 44-46).

ABBOTT, G. F.: 'Turkey, Greece, and the Great Powers: A Study in Friendship and Hate.' (London, 1916, Scott.) [With Maps.]

CHARRIĖRE, E.: 'Négociations de la France dans le Levant'=Collection de Documents Inédits sur l'Histoire de France, 1tere Série, Histoire Politique.' (4 vols., Paris, 1848-60.) 
DE SAINT PRIEST, F. E. DE GUIGNARD, COMTE: 'Mémoires sur l'Ambassade de France en Turquie et sur le commerce des Français dans le Levant.' (Paris, 1877, Leroux.)

EPSTEIN, M.: 'The Early History of the Levant Company.' (London, 1908, Routledge.)

FOREIGN OFFICE, HISTORICAL SECTION: 'The Eastern Question'=Peace Handbooks, No. 66. (London, 1920, H. M. Stationery Office.)

FOREIGN OFFICE, HISTORICAL SECTION: 'France and the Levant'=Peace Handbooks, No. 66. (London, 1920, H. M. Stationery Office.)

HOLLAND, T. E.: 'The European Concert in the Eastern Question.' (Oxford, 1885, Clarendon Press.) [Documented.]

MARRIOTT, J. A. R.: 'The Eastern Question: An Historical Study of European Diplomacy.' (Oxford, $1918^{2}$, University Press.)

MASSON, P.: 'Histoire du Commerce Français dans le Levant au xvii siècle.' (Paris, 1896.)

STRUPP, K.: 'Ausgewählte diplomatische Aktenstücke zur Orientalischen Frage.' (Gotha, 1916, Perthes.)

URSU, J.: 'La Politique Orientale de François I. 1515-47.' (Paris, 1908.)

(iii) Secret and Public Diplomatic Agreements since the Outbreak of the European War (pp. 47-106). 
March 1915: Note addressed to Russia by her Allies (in answer to her Note of the $4^{\text {th }}$ March 1915 addressed to them), recognizing her title to the possession of Constantinople and adjacent territories commanding the Straits. [This title was implicitly renounced, after the Russian Revolution, by successive Russian Governments, in proclamations published on the $10^{\text {th }}$ April and the $19^{\text {th }}$ May 1917 . The text of the Russian Note of the $4^{\text {th }}$ March 1915, with a précis of the Allies' reply, as embodied in an official memorandum in the Russian archives, was afterwards published by the Bolsheviks.]

$26^{\text {th }}$ April 1915: Agreement between France, Russia, Great Britain, and Italy, signed at London. [Secret, afterwards published officially=British Parliamentary Paper, Cmd. 671 (Miscellaneous, No. 7), 1920.]

May 1916: Agreement between Great Britain, France, and Russia regarding the disposal of Asiatic Turkey='Sykes-Picot Agreement.' [Secret, afterwards published by the Bolsheviks.]

April 1917: Agreement made at St. Jean de Maurienne between the Prime Ministers of Great Britain, France, and Italy in pursuance of Art. 9 of the Agreement of London. [Secret.]

$30^{\text {th }}$ October 1918: Armistice between the Allied Powers and Turkey. [Official text published in the Times of the $2^{\text {nd }}$ November 1918.]

11 ${ }^{\text {th }}$ May 1920: Draft Treaty presented to the Delegates of the Ottoman Government of Constantinople. [Official summary published in the Times of the $12^{\text {th }}$ May 1920.] 
$10^{\text {th }}$ August 1920: Treaty of Peace with Turkey, signed at Sèvres=British

Parliamentary Paper, Cmd. 964 (Treaty Series, No. 11), 1920.

10 ${ }^{\text {th }}$ August 1920: Tripartite Agreement between the British Empire, France, and Italy respecting Anatolia, signed at Sèvres=British Parliamentary Paper, Cmd. 963 (Treaty Series, No. 12), 1920.

$10^{\text {th }}$ August 1920: Treaty $<$ respecting the protection of minorities $>^{1}$ between the Principal Allied and Associated Powers and Greece, signed at Sèvres=British Parliamentary Paper, Cmd. 960 (Treaty Series, No. 13), 1920.

$20^{\text {th }}$ October 1921: Accord signé à Angora, le 20 Octobre 1921, entre M. Franklin-Bouillon, ancien ministre, et Youssouf Kemal Bey, Ministre des Affaires Étrangères du Governement de la Grande Assemblée Nationale d'Angora. [Published, as an enclosure to a dispatch from the British Ambassador at Paris, in British Parliamentary Paper, Cmd. 1556 (Turkey, No. 2), 1921.]

$5^{\text {th }}$ November to $15^{\text {th }}$ December 1921: Correspondence between His Majesty's Government and the French Government respecting the Angora Agreement of October 20, 1921=British Parliamentary Paper, Cmd. 1570 (Turkey, No. 1), 1922.

$29^{\text {th }}$ March 1922: Decisions concerning the Near East, communicated by the Foreign Ministers of Great Britain, France, and Italy, sitting in conference

\footnotetext{
${ }^{1}$ A similar treaty was also signed by the representatives of Armenia.
} 
at Paris, to the Governments of Athens, Constantinople, and Angora.

[Official summary published in the Times of the $28^{\text {th }}$ March 1922.]

\section{CHAPTER IV}

(i) Position of Anatolia in the East Roman Empire (pp. 109-110).

BURY, J. B.: 'The Imperial Administrative System in the $9^{\text {th }}$ century, with a revised text of the Kleterologion of Philotheos'=British Academy Supplemental Papers, I. (London, 1911, Oxford University Press.)

GELZER, H.: 'Genesis der Byzantinischen Themenverfassung'=Abhandlungen Phil.-Hist. Classe der Kon. Sächs. Gesellschaft der Wiss., vol. xviii. No. 5. (Leipzig, 1899, Teubner.)

PHILOTHEOS. See Bury.

(ii) Agrarian Question in East-Central Anatolia during the

Tenth and Eleventh Centuries (pp. 110-114).

TESTAUD, G.: 'Des Rapports des Puissants et des Petits Propriétaires Ruraux dans l'Empire Byzantin au x Siècle.' (Bordeaux, 1898.) 
'USPENSKY, TH.: 'On the History of Peasant Proprietorship in Byzantium.' (Petrograd, 1883, Journal of Ministry of Public Instruction, vol. ccxxv. pp. 30-87 and 301-60.) [In Russian.]

'USPENSKY, TH.: 'Considerations of the History of Agriculture in Byzantium.' (Petrograd, 1888, Journal of Ministry of Public Instruction, vol. cclix. pp. 229-59.) [In Russian.]

${ }^{1}$ VASIL'evsky, V.: 'Materials for the Internal History of the Byzantine Empire: I. Measures for the Protection of Peasant Proprietorship.' (Petrograd, 1879, Journal of Ministry of Public Instruction, vol. ccii. pp. 160-232.) [In Russian.]

(iii) Turcification of Anatolia (pp. 111-120).

DAWKINS, R. M.: 'Modern Greek in Asia Miner.' (Cambridge, 1916, University Press.)

LAURENT, J.: 'Byzance et les Turcs Seljoucides dans l'Asie Occidentale jusqu'en 1081'=Annales de l'Est, 28 Année, fasc. ii. (Nancy, 1919, Berger-Levrault.)

RAMSAY, Sir W. M.: 'The Intermixture of Races in Asia Minor: Some of its Causes and Effects'=Proceedings of the British Academy, vol. vii. (London, 1917, Oxford University Press.)

${ }^{1}$ References taken from Krumbacher, K.: 'Geschichte der Byzantinischen Literatur.' (Munich, 1897, Beck.) 
RAMSAY, Sir W. M.: 'The Turkish Peasantry of Anatolia.' (Quarterly Review, January 1918.)

TSAKYROGLU, M.; 'Peri Yurúkon <Yuruks>: Ethnoloyikì Meléti.' (Athens, 1891.)

WÄCHTER, A.: 'Der Verfall des Griechentums in Kleinasien im xiv Jahrhundert.' (Leipzig, 1903, Teubner.)

(iv) History of Arab Nationalism in Syria (p. 117).

AZOURY, NEGIB: 'Le Réveil de la Nation Arabe dans l'Asie Turque.' (Paris, 1905, Plon-Nourrit.)

ISKANDER OF BEYRUT: 'The Lebanon in Turmoil: Syria and the Powers in 1860'-translated from the Arabic by Scheltema, J. F.=Yale Oriental Series, Researches, vol. 7. (New Haven, 1920, Yale University Press.)

(v) Greek Renascence in Anatolia (pp. 121-129).

DIETRICH, K.: 'Das Griechentum Kleinasiens'=Länder u. Völker der Türkei, Heft. ix. (Leipzig, 1915, Veit.) [English translation published by AmericanHellenic Society (New York, 1918, Oxford University Press, American Branch).]

MACCAS, L.: 'L'Hellénisme de L'Asie Mineure: Son Histoire, sa Puissance, son Sort.' (Paris, 1919, Berger-Levrault.) 
PONTUS, NATIONAL DELEGATION OF THE EUXINE: 'Memorandum submitted to the Peace Conference.' (Manchester, 1919, Norbury \& Natzio.)

(vi) Aivali (pp. 121-122).

APOSTOLÁKIS, I. DH.: 'Kydhoniakè Meléte ke Parallilismí: vol. i. pt. 1: Ta pro tis Katastrophís.' (Kydhoniés=Aivali, 1914, 'Ilios' Press.)

SAKKARIS, G.: 'Istoria ton Kydhonión’ (Athens, 1920, Vitsikunákis.)

(vii) Conflict between Greek and Turkish Nationalism in Anatolia, 1908-18 inclusive (pp. 131-145).

ANON.: 'L'Hellénisme de l'Asia Mineure et la Jeune Turquie: Protestation et Appel à l'Humanité Civilisée, par un témoin oculaire des crimes turcs.' (Place and date of publication omitted.) [Greek source.] CARNEGIE ENDOWMENT FOR INTERNATIONAL PEACE, DIVISION OF INTERCOURSE AND EDUCATION: 'Report of the International Commission to Inquire into the Causes and Conduct of the Balkan Wars.' (Washington, D.C., 1914.) [For the connections between the exodus of Turkish civilians from Rumelia and the persecution of Greek civilians in Anatolia, see Chapter IV., pp. 138-139, of this book.] 
GREEK MINISTRY FOR FOREIGN AFFAIRS: 'Persecutions of the Greek

Population in Turkey since the Beginning of the European War, according to Official Reports of Hellenic Diplomatic and Consuler Agents.' (London, 1918, Constable.)

GREEK MINISTRY FOR FOREIGN AFFAIRS, PRESS BUREAU: 'LeS

Persécutions Antigrecques en Turquie de 1908 à 1921 devant la 3

Assemblée Nationale à Athènes, Séances des 5, 6, et 8 Avril 1921.'

(Athens, 1921.)

MATARANGA, A.: 'Black Days in the History of the pure Hellenic Provinces of Kydhoniès and Moskhonísia <Mávre Imére ton Ellinikotáton Eparkhiòn Kydhoniòn ke Moskhonisfon>: An Accurate Narrative of their Persecutions, Deportations, and other Sufferings, 1914-19.' (Smyrna, 1919, 'Mélissa' Press). [In Greek.]

PATRIARCHATE, OECUMENICAL: 'Persecution of the Greeks in Turkey, 191418.' (Constantinople, 1919.)

\section{CHAPTER VI}

(i) Geography of Anatolia (pp. 212-219).

BAEDEKER, K.: 'Konstantinopel and Kleinasien.' (Leipzig, 1914, Baedeker.)

FOREIGN OFFICE, HISTORICAL SECTION: 'Anatolia'=Peace Handbooks, No. 59. (London, 1920, H. M. Stationery Office.)

KONDOYÁNNIS, P. M.: 'Yeographía Mikràs Asías.' (Athens, 1921, Petrákos.) 
PHILIPPSON, A.: 'Reisen and Forschungen im westlichen

Kleinasien'=Ergänzungshefte 167, 172, 177, 180, 183 zu Petermann's

Mitteilungen. (Gotha, 1910-15, Perthes.)

RAMSAY, SIR W. M.: 'CCities and Bishoprics of Phrygia.' (2 vols., Oxford, 1895-

7, University Press.)

RAMSAY, SIR W. M.: 'Historical Geography of Asia Minor'=Royal Geographical

Society, Supplementary Papers, vol. iv. (London, 1890, Murray.)

RAMSAY, SIR W. M.: 'Historical Geography of Asia Minor'=Royal Geographical

Society, Supplementary Papers, vol. iv. (London, 1890, Murray.)

(ii) Maps.

ANDERSON, J. G. C.: Asia Minor, $1: 2,500,000=$ Murray's Handy Classical

Maps Series. (London, 1903, Murray.)

BRITISH ARMY, GENERAL STAFF, GEOGRAPHICAL SECTION: No. 2907, Asia Minor, 1:250,000. (London, War Office.)

KIEPERT, R.: Karte von Kleinasien, 1:400,000. (Berlin, Dietrich Reimer <Ernst Vohsen>.)

PHILIPPSON, A.: Topographische Karte des westlichen Kleinasiens 1:300,000, 6 sheets. (Gotha, 1910, Perthes.) 
SCHWEIGER-LERCHENFELD, A. VON: Kulturkarte Kleinasiens, 1:2,000,000. (Vienna, 1878, Mitteilungen der K. K. Geographischen Gesellschaft, vol. xxi.)

\section{CHAPTER VII}

(i) Past Treatment of Minorities in the West (pp. 267-269).

ARNOLD, C. F.: 'Ausrottung des Protestantismus in Salzburg unter Erzbischof Firmian und Seiner Nachfolgern'=Verein für Reformations-geschichte, Nos. 67 and 69. (2 Heften, Halle, 1901-2.)

LEA, H. C.: 'The Moriscoes of Spain: Their Conversion and Expulsion.' (London, 1901, Quaritch.)

SOKOLOW, NAHUM: 'History of Zionism, 1600-1918.' (2 vols., London, 1919, Longmans.)

TURBERVILLE, A. S.: 'Mediaeval Heresy and the Inquisition.' (London, 1920, Crosby Lockwood.)

VECCHIO, A. DEL, E CASANOVA, E.: 'Le Rappresaglie nei Communi medievali e specialmmente in Firenze.' (Bologna, 1894.) [With bibliography.]

(ii) Past Treatment of Minorities in the Middle East (pp. 267-269).

(a) Under the Arab Empire.

ARNOLD, SIR T. W.: 'The Preaching of Islam.' (London, 1913, Constable.) 
BELIN, F. A.: 'fetoua ralatif à la condition des Zimmis. . . depuis l'établissement de l'Islamisme jusqu'au milieu du viii siècle de l'Hégire, traduit de 'Arabe.' (Paris, 1852.)

GOTTHEIL, R. J. H.: 'Dhimmis and Moslems in Egypt,'=Old Testament and Semitic Studies in Memory of W. R. Harper, vol. ii. (Chicago, 1908, University Press.)

MARGOLIOUTH, D. S.: 'The Early Development of Mohammedanism,'=Hibbert Lectures, $2^{\text {nd }}$ series. (London, 1914, Williams \& Norgate.)

MUHAMMAD IBN ‘ALI, called ibn-al-Nakkash. See Belin, F. A.

(b) Under the Ottoman Empire.

FRANCO, M.: 'Essai sur l'histoire des Israélites de l'Empire Ottoman, depuis les origins jusqu'à nos jours.' (Paris, 1897, Durlacher.)

MENDELSSOHN, S.: 'The Jews in Asia, especially in the $16^{\text {th }}$ and $17^{\text {th }}$ centuries.' (London, 1920, Kegan Paul.)

STEEN DE JEHAY, F. VAN DEN: 'De la Situation Légale des Sujets Ottomans Non-Musulmans.' (Brussels, 1906.)

TRIETSCH, DAVIS: 'Die Juden der Türkei,'=Länder und Völker der Türkei, No. 8 (Leipzig, 1915, Veit.)

(iii) Massacres of Armenians (pp. 265-266).

HARRIS, J. RENDEL \& H. B.: 'Letters from the Scenes of the Recent Massacres in Armenia <1895-7>.' (London, 1897, Nisbet.) 
BRITISH GOVERNMENT: 'The Treatment of Armenians in the Ottoman Empire: Documents presented to Viscount Grey of Fallodon, Secretary of St ate for Foreign Affairs,'=Parliamentary Paper, Miscellaneous, No. 31, 1916.

LEPSIUS, J.: 'Deutschland und Armenien, 1914-18: Sammlung Diplomatischer Aktenstücker.' (Potsdam, 1919, Tempelverlag.)

(iv) Massacres of Greeks and Turks in Anatolia since the $15^{\text {th }}$ May 1919 (pp. 270-319).

GEHRI, M. (Délégué du Comité International de la Croix Rouge): 'Mission d'Enquête en Anatolie, 12-22 Mai 1921,'=Extrait de la Revue Internationale de la Croix Rouge, 3 Année, No. 31, 15 juillet 1921, pp. 721-735. (Geneva, 1921.)

INTER-ALLIED COMMISSION OF INQUIRY, dispatched by the British, French, and Italian High Commissioners at Constantinople: 'Reports on Atrocities in the Districts of Yalova and Guemlek and in the Ismid Peninsula,'=British Parliamentary Paper, Cmd. 1478 (Turkey, No. 1), 1921.

OTTOMAN GOVERNMENT, Ministry of Interior, Department of Refugees:

Publications, Nos. 4 and 5='Greek Atrocities in Turkey, First and Second Books.' (2 vols., Constantinople, 1921, Ahmed Ihsan \& Co.'s Press.) [In English.]

PONT, CONSEIL CENTRAL DU (Athens, Rue Paparigopoulou 15): 'Livre Noir: La Tragédie du Pont, 1914-22.' (Athens, 1922.) [In French and English.] 


\section{CHAPTER VIII}

(i) Western Prejudice (passim).

TOYNBEE, ARNOLD J.: 'The Murderous Tyranny of the Turks.' (London, 1917, Hodder \& Stoughton.) [An example-perhaps not worse than the average—of the wrong attitude towards the 'Eastern Question.']

(ii) Break-up of Ancient Christendom (pp. 328-329).

(a) Secession of the Middle Eastern Churches.

KLEYN, H. G.: 'Jacobus Baradaeus, the founder of the Syrian Monophysite Church.' (Leyden, 1882, Brill.) [In Dutch. Jacob Baradaeus destroyed the authority of the Catholic Church in Syria and Egypt by building up a revolutionary Monophysite ecclesiastical orgaisation. He spent a large part of his life 'on the run,' but the Roman Government could not cope with him.]

LABOURT, J.: 'Le Christianisme dans l'Empire Perse sous la Dynastie Sassanide.' (Paris, 1904, Lecoffre.)

TER-MINASSIANTZ, E.: 'Die Armenische Kirche in ihren Beziehungen zu den syrischen Kirchen bis zum Ende des 13 Jahrhunderts.' (Leipzig, 1904, Hinrichs.)

WOODWARD, E. L.: 'Christianity and Nationalism in the Later Roman Empire.' (London, 1916, Longmans.)

(b) Breach between the Catholic (=Western) and the Orthohdox 
(=Near Eastern) Church.

BRÉHIER, L.: 'La Querele des Imaes, 8 -9 siècles.' (Paris, 1904, Bloud.)

BRÉHIER, L.: 'Le Schisme Oriental du xi siècle.' (Paris, 1899, Leroux.)

COVEL, DR. J.: 'Some account of the Present Greek Church.' (Cambridge, 1722.)

GARDNER, A.: 'Theodore of Studium, his Life and Times.' (London, 1905, Arnold.)

HELLADIUS, A.: 'Status praesensEcclesiae Graecae, in quo etiam causae exponuntur cur Graeci Moderni Novi Testamenti editions in GraecoBarbarâ Linguâ factas acceptare recusent.' (Nuremberg (?), 1715.)

NORDEN, W.: 'Papsttum und Byzanz, bis 1453.' (Berlin, 1903, Behr.)

PARGOIRE, J.: 'L'Église Byzantine, A.D. 527-847.' (Paris, 1905, Lecoffre.)

RYCAUT, SIR PAUL: 'The Present State of the Greek and Armenian Churches, A.D. 1678.' (London, 1679.)

(iii) Hellenistic Element in Islam (p. 329).

BECKER, C. H.: 'Christentum und Islam' (Tübingen, 1907, Mohr.)='Christianity and Islam.' (New York, 1910, Harper.)

BROWNE, E. G.: 'A Literary History of Persia: vol. i., from the Earliest Times until Firdawsi.' (London, 1902, Fisher Unwin.)

CARRA DE VAUX: 'Les Penseurs de l'Islam: vol. i.., Les Souverains, l'Histoire et la Philosophie Politique; vol. ii., Les Géographes, les Sciences Mathématiques et Naturelles.' (Paris, 1921, Geuthner.) 
DIETERICHI, FR. H.: Works, passim. [See British Museum Catalogue.]

GÜTERBOCK, K.: 'Islam im Lichte der byzantinischen Polemik.' (Berlin, 1912, Guttentag.)

IBN KHALDUN: 'Prolegomena <Muqaddamāt>.' (In Arabic, edition of complete works, 7 vols., Bulaq, A. H. 1284; French translation by Baron M'G. de Slane, 3 vols., Paris, 1863-8, Imprimerie Impériale.)

NICHOLSON, R. A.: 'Studies in Islamic Mysticism.' (Cambridge, 1921, University Press.)

O'LEARY, DE L.: 'Arabic Thought and its Place in History.' (London, 1922, Trübner.)

SHAHRASTANI: 'Kitabu'I-Milal wa'n-Nihal <Book of Religious and Philosophical Sects>.' (Arabic text edited by W. C. Cureton, London, 2 vols., 1842-6; German translation, with notes, by Th. Haarbrücker, 2 parts, Halle, 18501.)

SPITTA, W.: 'Zur Geschichte Abu'I-Hasan al-Ash'aris.' (Leipzig, 1876.)

STEINER, H.: 'Die Mu’taziliten oder die Freidenker im Islam.' (Leipzig, 1865, Hirzel.)

STEINER, H.: 'Die Mu'taziliten als Vorläufer der islamischen Dogmatiker und Philosophen.' (Leipzig, 1865.)

WELLHAUSEN, J.: 'Religiös-Politischen Oppositions-Parteien im Alten Islam'=K. Ges. Wiss. zu Göttingen, Phil. Hist. Klasse, N.f., v, 2. (Berlin, 1901, Weidmann.) 
(iv) Adhamándios Koraïs (pp. 335-337).

KORAÏS, A.: 'Apánthisma Epistolón <Selected Letters>,' edited by I. Rotas. (2 vols., Athens, 1839 and 1841, Rallis.)

KORAÏS, A.: 'Epistolé <Letters>,' ed. by Dhamalas, N. M. (3 vols., Athens, 1885-6.)

KORAÏS, A.: 'Mémoire sur l'Etat Actuel de la Civilisation dans la Grèce.' (Paris, 1803)='Ypómnima perì tis parúsis katastáseos tu politismù en Elládhi.' (Athens, 1853, Philadhelphéfs.)

THERIANÓS, DH.: 'Adhamándios Koraïs.' (3 vols., Trieste, 1889-90, Austrian Lloyd Press.)

(v) The names 'Éllinas' and 'Romyós' (pp. 336-337).

BURY, J. B.: 'History of the Later Roman Empire.' (2 vols., London, 1889, Macmillan.) [See vol. ii., bk. iv., pt. 2, ch. vii.: 'The Language of the Romaioi in the Sixth Century.'] POLÍTIS, N. G.: Éllines I Romyi? <Hellenes or Rum?>.' (Athens, 1901, Sakellarios.) [This pamphlet originally appeared as a letter to the Press, in answer to one from the poet Kostis Palamás, in which the latter had maintained that 'Romyós,' and not 'Éllinas' <or, in purist form, 'Éllin'>, was the true national name of the Modern Greeks. Mr. Politis sets out to prove not only that the name 'Éllinas' was occasionally employed during the Middle Ages as a literary affectation by the learned, but that it had never dropped out of the popular consciousness - in fact, that its use during the War of Independence and 
thereafter was a survival rather than a revival. Without wishing to show disrespect to the memory of this distinguished scholar, I venture to state my opinion that in this controversy he has not proved his case.]

(vi) Economics and Climatology of Nomadism (pp. 338-341).

CONSTEN, H.: 'Weideplätze der Mongolen im Reiche der Chalcha.' (2 vols., Berlin, 1919, Dietrich Reimer).

DEMOLINS, E.: 'Comment la Route crée le Type Social,' vol. i., chi. i.: 'La Route des Steppes: Type Tartare-Mongol.' (Paris, no date, Didot.)

HERBETTE, F.: 'Le Problème du Dessèchement de l'Asie Intérieure=Annales de Géographie, 1914, vol. xxiii., No. 127. (Paris, 1915, Colin.)

HUNTINGTON, ELLSWORTH: 'The Climatic Factor as illustrated in Arid America'=Carnegie Institution, Publication 192. (Washington, D.C., 1914.) HUNTINGTON, ELLSWORTH: 'The Pulse of Asia: A Journey in Central Asia illustrating the Geographical Basis of History.' (Boston and New York, 1907, Houghton Mifflin.)

PEISKER, J.: 'Die älteren Beziehungen der Slawen zu Turko-Tataren und Germanen und ihre sozial-geschichtliche Bedeutung.' (Stuttgart, 1905.) PEISKER, J.: 'The Asiatic Background'=Cambridge Mediaeval History, vol. i. (Cambridge, 1911, University Press.)

PEISKER, J.: 'The Expansion of the Slavs'=Cambridge Mediaeval History, vol. ii. (Cambridge, 1913, University Press.) 
PUMPELLY, R.: 'Explorations in Turkestan, Expedition of 1903.' (Washington, D.C., 1905, Carnegie Institution.)

PUMPELLY, R.: 'Explorations in Turkestan, Expedition of 1904: Prehistoric Civilisations of Anau; Origins, Growth, and Influence of Environment.' (2 vols., Washington, D.C., 1908, Carnegie Institution.)

(vii) Eruptions of Nomads during the Dry Period A.D. 950-1250 (pp. 340-341 and 114-115).

BLOCHET, E.: 'Introduction à l'histoire des Mongols de Fadl Allah Rashid edDin'=Gibb Memorial Series, xii. (London, 1910, Luzac.)

CAHUN, L.: 'Introduction à l'Histoire d'Asie: Turcs et Mongols, des origins à 1405.' (Paris, 1896.)

CURTIN, J.: 'The Mongols: A History.' (Boston, 1908, Little, Brown \& Co.)

CZAPLICKA, M. A.: 'The Turks of Central Asia in History and at the Present Day.' (Oxford, 1918, University Press.) [Full Bibliography.]

DIETERICH, K.: 'Byzantinische Quellen zur Länder-und Völkerkunde: Teil II., Das Gebiet der neueren Wandervölker.' (Leipzig, 1912, Wigand.)

HAMMER-PURGSTALL, J. VON: 'Geschichte der Goldenen Horde in Kiptschak.' (Pest and Vienna, 1840.) [With bibliography.]

HOWORTH, SIR H. H.: 'History of the Mongols.' (3 parts in 4 vols., London, 1876-88, Longmans.)

PLANO CARPINI, JOHN DE: 'Libellus historieus Ionnis de Plano Carpini, qui missus est legatus ad Tartaros A.D. 1246 ab Innocentio IV., Pontifice 
Maximo.' (Ed., with Hakluyt's English version, by C. R. Beazley, London, 1903, Hakluyt Society.)

RUBRUQUIS, WILLIAM DE: 'Itinerarium anno gratiae 1253 ad partes

Orientales.' (Ed., with Hakluyt's English version, by C. R. Beazley, in same volume as Plano Carpini, q.v.)

POLO, Book of SER MARCO, edited (in English translation) by Col. Sir H. Yule ( $2^{\text {nd }}$ edition revised by H. Cordier, 2 vols., London, 1903, Murray, and Supplement, 1920.)

STRAKOSCH-GRASSMAN, G.: 'Der Einfall der Mongolen in Mitteleuropa in den Jahren 1241-2.' (Innsbruck, 1893.) [5 maps.]

(viii) Russian Colonisation of the Pasture-Lands (pp. 341-342).

BRITISH ADMIRALTY, INTELLIGENCE DIVISION, GEOGRAPHICAL SECTION:

'Handbook of Siberia and Arctic Russia, vol. i., General.' (London, 1921, H.M. Stationery Office.) [With map.]

MAVOR, J.: 'Economic History of Russia.' (2 vols., London, 1914, Dent.) RUSSIAN DEPARTMENT OF AGRICULTURE, IMMIGRATION COMMITTEE:

'Aziatskaya Rossiya.' (3 parts 4 and Atlas fol., Petrograd, 1914.)

WIEDENFELD, K.: 'Sibirien in Kultur and Wirtschaft.' (Bonn, 1916, Weber.)

(ix) The Volga Tursk (PP. 355-357). 
ALL-RUSSIAN MOSLEM CONGRESS, held at Moscow in May 1917: Speeches of the delegates, especially M. M. Tsalikov and Rasulzadé. (German translation in Neuer Orient of Berlin, vol. ii., No. 10 , of the $20^{\text {th }}$ February 1918.)

ALTDORFFER, H.: 'Kongresse der Mohammedaner Russlands in Kazan.' (Neuer Orient, vol. ii., Nos. 11 and 12, of the $20^{\text {th }}$ March 1918.)

ALTDORFFER, H.: 'Ethnographische Verhältnisse zwischen Wolga und Ural.' (Neuer Orient of Berlin, vol. ii., Nos. 11 and 12, of the $20^{\text {th }}$ March 1918.) BRITISH ADMIRALTY, INTELLIGENCE DIVISION, GEOGRAPHICAL SECTION: 'Manual on the Turanians and Pan-Turanianism.' (London, 1921, H.M. Stationery Office.) [With map.]

ERUSLANOV, P.: 'Mahometan Propaganda among the Cheremiss < pagan Finns> of the Ufa Government.' (Moscow, 1895.) [In Russian.] TURNERELLI, E.T.: 'Kazan.' (2 vols., London, 1854, Bentley.)

(x) The Capitulations (p. 358).

BROWN, P.M.: 'Foreigners in Turkey: Their Juridical Status.' (Princeton, 1914, University Press.)

*CASTELLANI, E.: 'Privilegi degli Stranieri in Oriente e nel Estremo Oriente.' (Rome, 1915.)

'DIPLOMATE ANCIEN': 'Le Régime des Capitulations: son histoire, ses applications, ses modifications.' (Paris, 1898, Plon-Nourrit.) 
FRENCH AND OTTOMAN GOVERNMENTS: Texte des traductions originales des Capitulations et des Traités conclus avec la Sublime Porte Ottomane (in 'Mémoires sur l'Ambassade de France en Turquie,' by le Comte de St. Priest, Paris, 1877, Leroux.)

GERMAN AND OTTOMAN GOVERNMENTS: Series of ten treaties in lieu of the previous Capitulations, signed by plenipotentiaries of the two Governments on the $11^{\text {th }}$ January 1917. (Reichs-Gesetzblatt, Jahrgang 1918, No. 55, published in Berlin on the $17^{\text {th }}$ May 1918.)

LIPPMAN, K.: 'Konsularjurisdiktion im Orient, ihre historische Entwicklung von den frühesten Zeiten bis zur Gegenwart.' (Leipzig, 1898.)

${ }^{*}$ OTTOMAN LAW of the $3^{\text {rd }}$ April 1917, regulating the status of Ottoman citizenship. (See Deutsche Levante-Zeitung, vol. vii., No. 22.)

OVERBECK, A. VON: 'Kapitulationen des Osmanischen Reiches'=Zeitschrift für Völkerrecht, Beigabe, vol. x. Heft 3. (Breslau, 1917.)

PEARS, SIR E.: 'Turkish Capitulations and the Status of British and other Foreign Subjects residing in Turkey.' (Law Quarterly Review, vol. xxi., No. 84, October 1905.)

PELISSIÉ DU RAUSAS, G.: 'Le Régime des Capitulations dans l'Empire Ottoman.' (2 vols., Paris, 1902 and 1911.) 


\section{ADDITIONAL NOTE ON CHAPTER V}

WHILE Chapter V. was in the press, the official apologia of the Greek

Administration in the occupied territories of Anatolia came into my hands. ${ }^{1}$ While the general tone of this document is naturally self-laudatory, the only point on which it contradicts my statements of fact is with regard to the Moslem École Polytechnique at Smyrna (see pp. 171 and 174 above. While admitting that the control of this institution had been taken over by the Greek authorities, the Greek 
official publication states that 210 Moslem children were still 'boarded, educated and taught various trades' in it, and that the Greek Administration 'expends for this purpose LT. 36,000 paper yearly.' My information was to the effect that the Greek Administration had not only taken over control but had appropriated the endowment to its own purposes. On the other hand, since I had no time to make a personal visit to the school, and cannot therefore speak at first hand, I must put on record the Greek as well as the Turkish version of what was done with regard to it, and must accept the defendant's statement unless or until I obtain stronger evidence controverting it. I note that the Greek apologia does not mention the proportion borne by the alleged number of inmates in 1921 (210) to the number maintained while the school was still under Turkish management, and it is conceivable that the same policy was adopted as in the case of the Turkish Hospital (see p. 176 above). I started further inquiries as soon as I read this passage. $^{2}$

In other respects, the Greek apologia contains several serious omissions and mis-statements. Not only is there no reference whatever to the Sultaniyyah School or to the Turkish Hospital, but the Greek Administration claims 'never once' to have 'requesitioned buildings belonging to the management of the Vakufs no laid a hand on their revenues,' and to have 'contributed to the improvement of all [the italics are mine] the Mohammedan schools which were in

\footnotetext{
${ }^{1}$ Greek Ministry for Foreign Affairs, Press Bureau: Greece in Asia Minor, Athens, 1921 [in English].

${ }^{2}$ At the moment of going to press, the answer to these inquiries arrived. It appears that the Greek Administration have appropriated part of the building to Greek military purposes (a point not mentioned in the apologia).
} 
operation under the former régime in the region ceded.' These statements are irreconcilable with the undisputed facts in regard to the treatment of the Sultaniyyah.

The apologia further mentions (p. 37) a dispensary for Moslem refugees opened since the $1^{\text {st }}$ March 1921 in the 'Rue Ketsedjidika, in the Turkish quarter.' Not knowing the street, I cannot say whether this is identical with the dispensary opened, by Turkish initiative and with Turkish funds, in the Iki Cheshmelik [lki Chesmé Jadesi] in lieu of the requisitioned hospital. The Greek apologia does not expressly state that the dispensary to which it refers was either administered or paid for by the Greek authorities. Finally, I note that the apologia confirms ( $p$. 6) my information (p. 176 above) that the new Turkish Educational Commission had only been given control over primary education.

The preface to the apologia contains the following passage:-'Certain organs of the European Press, misled by the enemies of Greece, recently published inexact information with regard to the Greek administration in Asia Minor. We regret that they should thus have become the defenders of Turkish barbarity, which has now withdraw[n] into the

\footnotetext{
On the other hand, the remainder has been left to the École Polytechnique, and the revenues of this institution (which is evidently identical with the Turkish

Orphanage referred to on p. 168) have been supplemented (as stated) out of the public funds of the occupied territories. On the balance, therefore, their treatment of the École Polytechnique is to the credit of the Greek Administration, and the references to this institution in Chapter V. must be corrected. I also learn that a second Turkish school (though not one of such importance as the Sultaniyyah) has been closed by the Greeks, and that, in place of the two, they have opened a (not at all equivalent) high school, as stated on p. 6 of their apologia.
} 
interior of Asia. On the other hand, we rejoice at the appearance of, and indeed we thank those who have given publicity to, these falsehoods, as they afford us the opportunity, in our reply, of making known to the general public the colossal civilising work carried out by Greece in Asia Minor, a work which no bona fide observer who has passed through Smyrna has failed to perceive and acclaim.'

In view of this passage, I must draw attention to the fact that, on my second visit to Smyrna ( $3^{\text {rd }}$ to $8^{\text {th }}$ August 1921$)$, I twice wrote to Mr. Sterghiádhis, reminding him of the kindness with which he had received me on my earlier visit, and asking him, in entirely courteous and inoffensive terms, to give me the favour of a further interview, in order to discuss with him frankly the events which I had witnessed in the interval. In each note, I mentioned the date of my departure and placed myself at his disposal at any previous hour convenient to him, and I delivered both notes at his house with my own hand. I received no answer, either written or verbal, to either of them, and, in the light of this, the protest quoted above from the Greek apologia appears to me hypocritical. 


\section{ADDITIONAL NOTE ON CHAPTER VII \\ The Greek version of events on the $15^{\text {th }}$ May 1919 \\ and the following days at Smyrna.}

DURING my visits to Smyrna in 1921, when I was seeking information with regard to the outbreak of atrocities which accompanied the original Greek landing there, I confined my inquiries to British eye-witnesses not born or bred in the Levant. Greek and Turkish witnesses are ex hypothesi interested parties, and French, Italian, and Levantine ${ }^{1}$ witnesses might be suspected a priori of an anti-

\footnotetext{
${ }^{1}$ I hasten to add that I altogether dissent from the view, frequently insinuated in Greek propaganda, that Levantines in the technical sense of the name (that is, people of Western descent who have been born and bred in the Levant) ought not to be heard in evidence because
} 
Greek bias, and therefore I felt it safer not to have recourse to them. Since my return to England, however, and particularly since Chapter VII. went to press, I have had submitted to me documents giving the Greek version of what occurred. I have hesitated to take them into consideration, first because it seemed sounder to rely exclusively upon the evidence of third parties, and secondly because I have no ex parte statements from the Greek side. On the other hand, the principal complaint (whether justified or not) from the Greek side against the Inter-Allied Commission of Inquiry which investigated these events in the summer of 1919 , has been that the Greeks were not at that time given a sufficient opportunity of presenting their case, and Greek apologists have argued that since they have been placed in the position of defendants, they are entitled to its privileges. I have therefore decided to discuss this Greek evidence in the present additional note, to which reference is made in a footnote to the text of Chapter VII.

My Greek informants are four in number:--

they are notoriously bad characters. The very numerous and important Western colonies in the Levant contain families of every class and individuals of every shade of character. So far as they differ from their kinsmen in their countries of origin, it is through having intermarried with local Orthodox and Gregorian Christians and having (in varying degrees) adopted their ways.

Reflections upon their credibility as witnesses, in such a case as the events that occurred at Smyrna on the $15^{\text {th }}$ May 1919, therefore reflect at least equally upon Greek witnesses. Indeed, the name Levantine had acquired a certain odium in the West because in popular usage there it is not confined to Levantines of Western origin, but is applied wholesale to the non-Moslem inhabitants of the Levant ports. Greek propaganda sometimes takes improper advantage of the double use of the name, by the singular device of using an existing prejudice against the Greek nation in order to create one against other people. 
(A) a gentleman who had been at Smyrna for many weeks before the events occurred, was present during their occurrence, ${ }^{1}$ and had the best opportunities for seeing what was going on;

(B), a naval officer on board a Greek warship anchored in the offing;

(C) and (D), two gentlemen in official positions connected with the late Venizelist Government, both of whom were peculiarly concerned with the facts and had special access to Greek official sources of information. (D) was in a higher position than (C), but had not the same opportunity for personal investigation, and except in so far as his evidence is derived from (C)'s, it seems to me considerably less valuable than that of the other three witnesses.

Informant (B) is Captain George Panás, C.M.G., at that time in command of the battleship Límnos. The other three desire to remain anonymous (all for legitimate reasons, which have no bearing on the value of their evidence). Their statements were avowedly transmitted to me in order to put the least unfavourable construction (from the Greek point of view) upon the events in question. On the other side, it is perhaps worth mentioning that these witnesses, while all Greeks, are none of them Anatolians.

In general, they do not dispute the broad facts of the massacre of Turks and looting of their property by Greek soldiers and civilians, but they seek to prove that the extent of both forms of excess was less than that alleged by nonGreek witnesses; that the Turks had previously arranged for resistance to the

\footnotetext{
${ }^{1}$ Not leaving Smyrna till the $21^{\text {st }}$ May 1919 , the day of Mr. Sterghiádhis's arrival.
} 
Greek occupation of the city; that the Turks fired the first shot; and that the Greek authorities subsequently took steps to stop the atrocities committed by their own side and to punish the offenders. I propose to summarise and compare their evidence very briefly on certain crucial points:--

(i) Numbers of killed and wounded.

(a) On the Turkish side.

On the $15^{\text {th }}$ May, (A) saw the Greek crowd on the quay kill two Turkish policemen, who had been arrested by Greek soldiers on the charge of firing from the windows of houses, and throw one Turkish officer into the sea. Visiting the Greek Red Cross Hospital after lunch, he saw dead and wounded Turks and Greeks being brought in, and carts full of corpses standing at the entrance. He testifies that, by the $17^{\text {th }}$ May, the American hospital at Smyrna had collected 48 Turkish corpses, and that 18 more had been found in the grounds of the British Gas Company, into which they had been thrown. On the $20^{\text {th }}$ May, he estimated the total Turkish casualties during the $15^{\text {th }}$ and $16^{\text {th }}$ May at 124 dead and 112 wounded. If the corpses subsequently washed up from the sea are taken into account, and allowance is made for those which did not come to his notice, this estimate does not conflict with that mentioned in Chapter VII.

(C), who made his investigations some time later, estimates the total deaths on both sides on the first day at about 100, and states that 'all witnesses agree' that the number of disarmed Turkish soldiers killed on the quay after their surrender was between 15 and 20 .

(b) On the Greek side. 
(A) quotes Captain Papayoryíu, commanding the company of évzoni (light infantry) which headed the column dispatched about 10 A.M. from the main point of disembarkation towards the Turkish government building (konak), as having stated to him (A) personally that, at the first outburst of firing, five Greek civilians and one soldier were shot dead, and fifteen persons (apparently including both Greek civilians and soldiers) were wounded. Captain Papayoryíu added that, in the process of occupying the konak, barracks, and prison he lost one more soldier killed, one who died of wounds a few days afterwards, and eleven wounded. On the afternoon of the $15^{\text {th }}$, (A) himself saw one dead and one dying evzone brought into the Greek Red Cross Hospital; and these must be identical with the two killed that morning in Captain Papayoryíu's company, for next day (A) attended the official funeral of 'the two evzones killed yesterday.'

(C) alleges that in an attack on the Greek Consulate, which was guarded by a detachment of Greek sailors, the latter were compelled to return the fire in self-defence, and that two 'military persons' ('stratitikí) who exposed themselves recklessly were killed. It is not clear whether the casualties thus described refer to Greek sailors or to persons in Turkish military uniform among the alleged assailants, but had two Greek sailors as well as two Greek soldiers been killed on the $15^{\text {th }}$, it is evident that they would have shared the honours of the official funeral next day. ${ }^{1}$

\footnotetext{
${ }^{1}$ A fuller version, since communicated to me, of (C)'s statement mentions explicitly that these two victims were Turks.
} 
On the Greek evidence, one may therefore safely reckon the casualties in killed among the Greek naval and military forces as one evzone killed outright on the $15^{\text {th }}$, one who died of wounds the same day, and one who died of wounds several days later. It is noteworthy, however, that this evidence is obtained by piecing together unofficial accounts; and although there must be exact records in the Archives of the Greek Ministry of War, the Greek Government have never, as far as I can make out, published any official return of casualties incurred on this occasion. This omission tells us strongly against them as similar omissions to publish statistics which must automatically have been recorded told against the British Government during the Irish terror.

(C) gives no estimate of Greek casualties. (D), to whom all official returns were accessible, lumps together the total Greek military and civilian casualties and puts them at 11 killed and 47 wounded. On the $20^{\text {th }}$ May, $(A)$ reckoned the total Greek casualties on the $15^{\text {th }}$ and $16^{\text {th }}$ (civilians and soldiers being similarly lumped together) at 25 killed and 72 wounded.

I must draw attention to the presumption, on which one of my English witnesses strongly insisted, that many of these Greek casualties were caused by Greek bullets. Both these English witnesses described to me how, when once the firing had begun, the Greek soldiers started shooting wildly in all directions, and they declared that this went on for several hours. Captain Panás writes that 'two men from my ship, forming part of the covering landing-party, were slightly 
wounded while at the Port Office ${ }^{1}$ [at the entrance to the northernmost of the two piers enclosing the inner harbour] from shots coming from the direction of the Custom House.' Now (A) mentions that the Custom House, as well as the Port Office, was occupied as early as 7:30 A.M. that morning by naval detachments from the Avérof, Límnos (Captain Panás's ship), and Léon; and the Custom House stands on the southern pier enclosing the inner harbour, while the Turkish firing broke out (according to Captain Papayoryíu's account) at a point south of this again. Captain Panás's and Captain Papayoryíu's statements only fit into one another on the hypothesis that the Greek naval detachment at the Custom House, seeing firing break out to the south, lost its head and began to shoot in all directions, incidentally wounding two Greek sailors stationed on the pier to the north.

(ii) Extent of the looting and destruction of Turkish property by Greek soldiers and civilians.

(A) testifies, as a first-hand witness, that general looting of Turkish shops and houses in the city of Smyrna began on the afternoon of the $15^{\text {th }}$ May, as soon as the Greek forces had passed through the city to the heights commanding it from the land side; that, while it was mostly perpetrated by native Greek civilians, soldiers were also implicated; that on the $16^{\text {th }}$ May, Mr. Mavrudhís, the Greek official representative at Smyrna before the military occupation, asked Colonel Zaphiríu, commanding the occupying forces, to land

\footnotetext{
${ }^{1}$ For the topography, see map between pp. 332 and 333 of Baedeker's Konstantinopel und
} 
naval detachments in order to restore order in the city and stop the plundering of Turks by Greeks; that Colonel Zaphiríu declined to do this, on the ground that he had already taken all necessary measures for the preservation of order, and contented himself with issuing a severe proclamation; and that official measures for the preservation of order were not in fact taken till the $19^{\text {th }}$ and $20^{\text {th }}$ May.

(A) also mentions incidentally the lifting of cattle belonging to Turks in the residential suburb of Bujá, and the partial or total looting and destruction of eight Turkish villages in the district of Vurla by the local Greek population.

Like my English witnesses, he describes the strong impression made on him, when he went out of doors on the morning of the $16^{\text {th }}$ May, by the fact that no Turkish shops were open and that no one was wearing a fez (the reason, given by my English witnesses, being that any one wearing a fez had been in danger of his life since the outbreak began the day before). In this connection, he adds that there was still intermittent firing that morning.

(iii) Was there a Turkish plan for armed resistance? ${ }^{1}$

(A), (B), and (C) all lay stress on inflammatory proclamations alleged to have been distributed among the Turkish population of Smyrna the night before the landing. They also put a sinister interpretation upon the fact that when the

\footnotetext{
Kleinasien (Leipzig, 1914, Baedeker).

${ }^{1}$ I must note that American informants reported to me very similar stories (on which they laid no stress, as they had no more proof of them than the Greeks have against the Turks) of the smuggling in of arms by the Greeks during the preceding weeks, particularly through the agency of the Greek Red Cross. (C) does not refer to this, but, in the fuller version now before me, he admits that, before the disembarkation of the Greek troops, the Greek civilian population of Smyrna had armed themselves by looting the military stores in which the local Turkish warmaterial had been deposited [by the Allied control-officers]. On the other hand, he states in this connection that the Greek military authorities, so far from distributing arms themselves, put a stop to the looting of the Turkish stores-a step which is greatly to their credit.
} 
news spread that Greek troops were to occupy the city the following morning, the Turkish population was panic-stricken and streamed out of the Turkish quarter on to the hills inland, where they lit fires and passed the night. This, however, was surely a symptom of fear (only too well justified by the event) and not of aggressive intentions, ${ }^{1}$ and the possibility of any widely-organised plan of resistance is ruled out by the time-table given by $(A)$. He states that the official announcement of the impending occupation was made simultaneously by Mr. Mavrudhís to the Greek community and by the representatives of the Allies to the Turkish community at 6:30 p.m. on the $14^{\text {th }}$ May, i.e. just thirteen hours before the landing began, and that it was only after this that the news spread through the city. Finally, $(C)$, while maintaining that a party among the Turks did make plans and arm itself, expressly exculpates the Turkish civil and military authorities, ${ }^{2}$ on the ground that, had they been implicated, they would not have 'limited their resistance' ${ }^{3}$ to the buildings round the konak, or have themselves remained in that locality.

(iv) Who fired the first shot?

The statements of all my four informants, in regard to this, can be traced back at second or third hand to the account given by Captain Papayoryíu, commanding the leading company of the evzone regiment which started, at 10 A.M. on the $15^{\text {th }}$ May, to march south along the quay, from the main point of

\footnotetext{
${ }^{1}$ See translations of the Turkish proclamations on p. 404.

${ }^{2}$ (D) incorrectly ascribes the opposite opinion to (C).
} 
disembarkation north of the inner habour, towards the konak. According to $(A)$, who obtained his version direct from Captain Papayoryíu, this company of evzones, and the crowd of Greek civilians that was following at their heels, were suddenly fired upon, on their march, from the Custom House warehouses on the one side and from Turkish kaiks, moored at or close to the quay, on the other. These indications fix the point at somewhere along the quay to the south of the Custom House pier, between it and the konak, for while the Custom House itself stands on the southern pier enclosing the inner harbour, the Custom House warehouses flank the quay on the land side for several hundred yards, running parallel to the thoroughfare along the quay, and the moorings of the Turkish kaiks are south of the Custom House pier. Moreover, this is about the point from which my English witnesses judged that the first sound of firing came. It therefore seems reasonably certain that the first firing did break out here, but who started it? We may dismiss the phrase 'volley-firing,' employed by (A). Volleys fired, literally at two or three yards' distance, into troops in column of route and a dense crowd of civilians, would certainly have inflicted far heavier casualties than those reported by the Greeks themselves. But was the trouble started by isolated shots fired by Turks? On this point I will quote a statement by (B) Captain Panás:--

'Captain Boyle, of H.M.S. Adventure [the British warship which was "in the port with its stern made fast to the quay," as stated by Captain Panás in another passage], one day

\footnotetext{
${ }^{3} \mathrm{~A}$ few lines further down, $(\mathrm{C})$ contradicts these words by affirming the 'absolute certainty' that
} 
while we were chatting over matters together, insisted also that no shots were fired from buildings around and [from the] Custom House, and based his belief on [the fact] that no arms were found afterwards, neither on a small Turkish gunboat in the harbour nor in the Custom House; but I certainly do not think that is proof enough, as rifles or revolvers may be easily hidden or thrown in the sea. Lots of Turkish boatmen were seen firing and were brought to me, but nothing was found in their boats, so evidently they had managed to sink whatever they had used for firing.'

This passage bears evident marks of frankness and good faith, but I doubt whether readers of it will be convinced by Captain Panás's reasoning. Obviously the burden of proof lies not upon the Turkish boatmen, to demonstrate their innocence in spite of the fact that no evidence was found against them, but upon the Greeks to show grounds for their accusation. Neither Captain Panás nor my three other Greek informants nor Captain Boyle nor the two English witnesses on whose information I have based my account in the text, were eye-witnesses of these particular occurrences, and the whole story goes back to the statements (unsupported by material evidence) of Captain Papayoryíu. I know nothing either to the credit or to the discredit of this Greek officer, but in view of what followed, he (as the responsible officer in command at the point where the outbreak 
occurred) had a stronger personal interest than any other individual concerned, in making out that the firing was started by Turks. On the strength of his account, presented at second-hand, I cannot alter my judgment, given in Chapter VII., that the provenance of the first shot is an open question. It is for the Greek Government to throw further light upon this vital point by obtaining and publishing sworn depositions from Captain Papayroyíu and from other Greek soldiers, Greek civilians, and Turkish boatmen who were actually eye-witnesses. Possibly the question has been investigated adequately by the Inter-Allied Commission of Inquiry, which a priori is a more impartial body than any Greek or Turkish official or non-official investigators; but that must remain unknown until the veto placed by the Allied Governments upon the publication of the Commission's Report has been removed.

With regard to subsequent firing by Turks, my English witnesses never witnessed any. On the other hand, (A), who was standing on the quay near the main point of disembarkation, states that when, about 10:10 A.M. on the $15^{\text {th }}$ May, word arrived of the outbreak further south, some Turks, concealed in the hotels along the quay, fired from the windows upon the disembarking troops, quite close to where he was. He does not state, however, either that he himself identified the persons firing as Turks, or that the Greek troops fired upon suffered any casualties. Readers acquainted with the circumstances of the first landings on the Gallipoli Peninsula during the Dardanelles Expedition, will receive this with skepticism. On that occasion, the casualties suffered by troops crowded upon transports and lighters brought up to the shore were murderous, and the points 
from which they were fired upon by the Turks opposing their landing were considerably further off than were the houses facing the Smyrna quay. (A) further mentions that at 8 A.M.-more than two hours earlier-certain suspected hotels along this part of the quay had been cleared of their occupants, as a safeguard, by Greek naval detachments. It is therefore improbable that the firing was directed against the disembarking troops, or that those who fired were Turks. My English witnesses testify, when once the firing had started, to firing having broken out all round them, but all the persons whom they actually saw firing were Greek soldiers or Greek civilians who had borrowed or seized soldiers' rifles. ${ }^{1}(A)$ himself repeatedly recurs to the fact that the civilians had got out of hand; mentions that one of his own friends, in his exaltation of spirits, borrowed a military rifle and uniform; and censures the troops for not having been sufficiently severe with the Greek crowd. Thus, while I do not doubt (A)'s word that he saw firing from neighbouring windows, I am not convinced by his explanation. Those who fired may have been Turks with a singularly bad eye for their targets, or they may have been Greeks firing at random. In the Near and Middle East, it is customary for people with firearms in their hands to fire into the air whenever their emotions are aroused, either pleasantly ${ }^{1}$ or unpleasantly. The other further information given by (A), or by my other Greek informants, on this question is at second-hand. (A) saw two Turkish policemen (those massacred by the Greek crowd: see above) and one 'komitajy' (i.e. as far as ocular evidence

\footnotetext{
${ }^{1}$ For the arming of the Greek civilians, see footnote on p. 395.
} 
went, a Turk in civilian clothes) being marched along under arrest, by Greek soldiers who alleged that they had been firing from windows.

The whole controversy as to who began the firing on the $15^{\text {th }}$ May 1919 at Smyrna, reminds me irresistibly of the similar controversy in regard to the outbreak at Louvain on the $25^{\text {th }}$ August 1914 , which I once had the unpleasant task of examining rather closely. After the publication of voluminous documents, interpretations, and counter-interpretations from the Belgian and the German side respectively, it became evident that the Germans could not substantiate their charge that the Belgians had fired first, while the Belgians (almost from the nature of the case) could not demonstrate what parties in a court of law are never asked to demonstrate—namely, that their opponents' charges against them were not merely unsubstantiated by the evidence brought forward, but were impossible in themselves. This, it seems to me, is the position in which the present controversy must be left until the Inter-Allied Commission's Report is published or further investigations are made. On the available evidence, it is not yet proved that the Turks fired the first shot, nor, on the other hand, is that yet disproved by counter-evidence to the effect that the first shot was fired by the Greeks. It may be added that whether the Greeks at Smyrna on the $15^{\text {th }}$ May 1919 , or the Germans at Louvain on the $25^{\text {th }}$ August 1914 , had or had not received any provocation for the acts which they committed, those acts completely eclipse in their atrocity the utmost provocation which those guilty of them respectively allege.

\footnotetext{
${ }^{1}$ E.g. on Easter Day.
} 
(v) Steps taken by the Greeks themselves to stop the Greek atrocities and punish the offenders.

This is the strongest part of the Greek case, for while such measures as were taken incidentally reveal the gravity of the crimes that had been committed, the fact that steps were taken offers a certain atonement (the only possible one) and, what is perhaps more important, a certain hope for the future. Atrocities, whether committed by Near Easterners, Middle Easterners, or Westerners, will never be brought to an end by repressive measures from outside, but only by shame or remorse in the minds of the guilty parties themselves.

While the Greek commandant, Colonel Zaphiríu, appears to have been guilty of culpable negligence in regard to the restoration of order, and the Greek soldiery of somewhat less culpable indulgence towards the Greek crowd, active steps towards stopping the killing and looting were apparently taken from the beginning by individual Greeks. ${ }^{1}$

Moroever, on the $18^{\text {th }}$ May, a court-martial was held by the Greek military authorities, and some severe sentences were passed. I give the statistics, which do not entirely coincide, of my several Greek informants:--

\begin{tabular}{|l|l|l|l|l|l|l|}
\hline Death & Hard & Hard & 'Irktí (C); & 'Phylákisis' (C); & Total \\
Sentence. & Labour & Labour & 'Détention' (D): & 'Emprisonnement' & Number \\
& for Life. & for a & 10 to 20 Years' & (D); 2 to 5 Years' \\
& & $\begin{array}{l}\text { Term } \\
\text { of } \\
\text { Years. }\end{array}$ & $\begin{array}{l}\text { Imprisonment } \\
\text { (M). }\end{array}$ & Imprisonment (M). & Sentences. \\
& & & & \\
\hline
\end{tabular}

${ }^{1}$ E.g. at Buja a Greek lawyer, Mr. Athenoyénis, is stated to have stopped the looting, with the assistance of other Greek inhabitants of good repute and of the local Greek Boy Scouts, and to have obtained the restoration of sixty per cent. of the stolen cattle to their Turkish owners. 


\begin{tabular}{|l|l|l|l|l|l|l|}
\hline & & & & & & \\
\hline$(\mathrm{C})$ & 3 & 4 & 3 & 12 & 53 & 74 (sic) \\
$(\mathrm{D})$ & 3 & 4 & 2 & 15 & 53 & {$[77]$} \\
$(\mathrm{M})^{2}$ & 3 & 4 & - & 14 & 53 & {$[74]$} \\
\hline
\end{tabular}

All three informants agree in stating that the persons condemned consisted of 48 Greeks, 13 Turks, 12 Armenians, and 1 Jew. The total of 74 is therefore probably correct, and the statistics of the various sentences (taken in the order of the schedule above) are probably 3 sentences of death; 4 of hard labour for life; 2 of hard labour for a term of years; 12 of longer, and 53 of shorter periods of ordinary imprisonment. None of those who give the above statistics mention how the different sentences were apportioned among the different nationalities, except for a statement by Mr. Mavrogordato that all three death sentences were passed upon Greeks. This is confirmed, for two out of the three, by (A), who, though he gives no general statistics, was present at the courtmartial, and describes the passing of the death sentence upon Konstandínos Tsigarás, a Greek civilian of Bujá, and upon Dhimítrios Tsarukhás, an evzone. ${ }^{1}$

(D) further mentions that Colonel Zaphiríu and Lieutenant-Colonel Stavrianópulos were both deprived of their commands and placed on the retired list, on account of their conduct during these days, and that Lieutenant-Colonel Stavrianópulos was also subjected to forty days' rigorous arrest. On the other

\footnotetext{
${ }^{2}$ Mr. John Mavrogordato, of 5 Linnell Close, Hampstead Garden Suburb, London, N.W. 11.
} 
hand, (C), and (D) following him, invoke the authority of the British naval officers on board H.M.S. Adventure for stating that both the Greek naval detachment stationed at the Custom House, and Lieutenant-Colonel Skhinás, commanding the $4^{\text {th }}$ Infantry Regiment, with the officers under him, made energetic efforts to restore order, to keep the crowd's hands off the Turkish prisoners, and to shelter the latter in warehouses.

(D) adds that a Graeco-Turkish mixed tribunal, for assessing damages and making reparations, was afterwards set up by the new Greek High Commissioner, Mr. Sterghiádhis, on his own initiative, and Mr. Mavrogordato estimates the total sum paid on his head at four million francs.

These facts are creditable and ought in fairness to be given just as much publicity as the others, but unfortunately the latter weigh considerably more heavily in the balance. In concluding this résumé of the Greek version of the case, I must again draw attention to the facts that none of my information, either in this supplementary note or in Chapter VII. itself, comes from Turkish sources; that the Report of the Inter-Allied Commission, which investigated these events within the first four months after they took place, has been withheld from publication, by a decision contrary to the usual practice of Governments in such circumstances; and that while the Turks have always pressed for its publication, Mr. Venizelos made energetic diplomatic demarches in order to prevent it. The Greeks take it for granted that the Commissioners were prejudiced against them;

\footnotetext{
${ }^{1} \mathrm{He}$ adds that they were executed the same evening.
} 
but they advance no proof of this, ${ }^{1}$ and there is no a priori likelihood of it. Insomuch as the four countries which the Commissioiners respectively represented were in alliance with Greece, and as their Governments had themselves taken the decision to send the Greek troops to Smyrna, the presumption is that the Commissioners were biassed in favour of Greece, if either way. But in view of the fact that they were distinguished public servants of four of the greatest civilised Western nations, and that the honour of none of the nations (as distinct from the Governments) to which they belonged was directly implicated in their verdict, there was a reasonable expectation that they would be impartial. If the Turks (the recent enemies of the Entente Powers) were eager that their verdict should be made public, and this in circumstances in which, ex hypothesi, they could not know for a fact what the verdict was, it is reasonable to infer from this a conviction on the Turks' part that an impartial inquiry into the events of the $15^{\text {th }}$ May 1919 and the following days at Smyrna, was bound to result in their own favour. Did Mr. Venizelos himself believe that any inquiry, properly conducted, would result in anything but discredit to his fellowcountrymen?

The Turkish Proclamations distributed at Smyrna on the evening of the $14^{\text {th }}$ May 1919.

\footnotetext{
${ }^{1}$ The facts which they adduce all find their natural explanation in the anxiety of the Commissioners to shield their Turkish witnesses. See Chapter III., pp. 79-80 above.
} 
I have made the following English translations from Greek translations, communicated to me, of the Turkish originals, to which I have not had access:--

'DOWN-TRODDEN TURK,--Your country [has been given] to the Greeks. Raise your voice in protest, to repudiate this flagrant injustice. All Moslems and all friends of the Turks will assemble this evening, and remain till morning, at the Jewish hospital. Attend, if possible, with all your household. This is your last day; do not neglect [this appeal], oppressed Turk!'

'UNHAPPY TURK,--They are robbing you of your rights and trampling on your honour, under the pretext of the Wilsonian Points. They say that the Greeks here are many [?the majority], and that the Turks will welcome the annexation of this region to Greece. On this account, they are handing over to Greece your beautiful country. We ask you: Are the Greeks more numerous? And do you consent to Greek domination? Show now of what sort [ . Query emend to =how many] you are. All your brothers are at the Jewish hospital. Flock there in your thousands, and show to the whole world your crushing superiority of numbers. Proclaim and demonstrate it, and [Lacuna in the Greek text]. On this occasion there is no distinction between rich and poor, educated and illiterate-only an 
overwhelming mass repudiating Greek domination. This is the supreme duty incumbent upon you. Do not fail. Faintheartedness is good for nothing. Hasten in hundreds of thousands to the Jewish cemetery. Put yourselves under the orders of the National Committee.

[Signed] 'The National Committee for the rejection of Union' [with Greece].

In these documents, at any rate in the form in which they have reached me, there is no incitement whatever to resist the Greek landing by force of arms. On the other hand, there is an explanation of the actual behaviour, as reported independently, of the Turkish population of Smyrna during the night between the $14^{\text {th }}$ and the $15^{\text {th }}$ May. The assembly en masse on a conspicuous hillside above the Turkish quarter, and the lighting of bonfires which made the crowd visible from the warships in the harbour, were evidently naïve and pathetic attempts at an improvised plebiscite or ocular demonstration of how the destiny of Smyrna ought to be decided on the principle of self-determination—as if a priori principles—Wilsonian or any other—had determined the decision of the 'Big Three' to send the Greeks to Smyrna, or as if Admiral Calthorpe could, on his own initiative, suspend his superiors' orders at the eleventh hour! No, the Smyrna Turks were obviously in need of a mandatory. They were far too ignorant of the methods of Western politics and administration to be fit to govern themselves. 


\section{ADDENDUM TO CHAPTER V, PAGE 194}

THE opinion, expressed in the text, that the Karamanly Orthodox Christians have never previously performed their ritual in Turkish, must be corrected by two pieces of testimony on the other side, which have just been brought to my notice by members of my seminar at the London University Institute of Historical Research. The references are to vol. i. p. 126 of Poujoulat, B.: 'Voyage à Constantinople' (Paris 1840-1, Ducollet, 2 vols.), and to p. 41 of Bowen, G. F.: 'Mount Athos, Thessaly and Epirus' (London, 1852, Rivingtons). Both these travellers state expressly that the Orthodox Christians in the interior were in their time using Turkish for their ritual (Poujoulat's words are 'l'Évangile et les prières de l'Église') as well as for their vernacular. Poujoulat testifies to this for the Christians of Kula and Ushaq, two places which he visited himself. 


\section{INDEX}

[Not including Table of Dates or List of Books or Additional Notes to Chapters V. and Vii.]

Note-the letter $\mathrm{n}$ after a number means that the reference is to a footnote on the page in question, but I have not added it in cases where there is a reference to both text and footnote on the same page. Particular references to certain general heads will be found classified respectively under these heads, in alphabetical order, and not indexed separately. the heads are:--Colonies, Commissions of Inquiry, Conferences (including Congresses), Education, Elections, Languages, Law, Minorities, Navies, Railways, Refugees (including Deportees), Revolutions, Treaties (including Agreements, Conventions, and 
Protocols), and Wars.

Abbasid Empire: see Arab Empire.

Abdu'l-Hamid, Sultan: 29, 131, 135-6, 166 n, 182-3, 202-4.

Abioi: 339.

Abyssinians: $359 n$.

Adalia, Gulf of: 216-17.

--town of: $51,77,120,218,226 n$.

Adam: 347.

Adana: $312 n$.

Adnan Bey, Dr.: 179.

Adrianople: 61.

Adriatic Sea: 197.

Aegean Sea: 34, 37-8, 69, 88, 121-2, 132, 142, 149, 220, 222, 231 n, 239, 333.

Aeschylus: 347.

Aetolia, Ancient: 41.

Afghanistan: 30, 46, 155.

Afium Kara Hissar: 57, 215-16, 218-19, 226 n, 228, 231, 233-4, 236, 239, 246.

Africa, Continent of: 334 .

--North: 30, 35.

--Tropical: 46, $60 \mathrm{n}$.

Africans, South: 334.

Agesilaos, King: 221. 
Agra: see Taj Mahal.

Agreements: see Treaties.

Ahmed at Constantinople, Mosque of Sultan: 10.

Aidin, District of: $290-1,319$.

--Town of: 123, 135, 151-2, 161, $166 n, 168,193,196-8$, 226-7, 229, 273-4, 299.

--Vilayet of: 68, 71, 78, 116 (Principality of), 120, $134 n, 280$.

Ainegöl: 247, 253.

Aivali, 17, $95 n, 121-2,125-7,141,143-4,168,332,355 n$.

--, Academy of: 122, 124.

Aivalyk: see Aivali.

Akbar, Emperor: $10 n$.

Akhissar, District of: 318.

--Town of: 289-90.

Akkeui (Kaza of Yalova): 263, 301-5, 307, 311.

--Acting hoja at: 303.

Alashehir: $173 n, 201,229,290$.

Albania: 18-19, 59.

Albanians:--Moslem: 136; Orthodox: 195.

Alcohol, Prohibition of: 240.

Aleppo: 56, 85 .

Alexákis, Mr. loánnis: $161 n$.

Alexander the Great: 22, 29, 128, 149, 222, 238.

--King of Greece: 83. 
Alexandretta: $85 n$.

Alexandria, Orthodox Patriarchate of: 8 .

Alfred, King: 128.

Algeria: $211 n, 224$.

Ali Bey of Ödemish: $171 n$.

Allenby, General Lord: 86.

Allied Governments, Note of $11^{\text {th }}$ January 1917 to President Wilson from the: 328.

'Alpine' Racial Type: 113, 119.

Alsace-Lorraine: $88-9$.

Amanus Tunnel: 85, 218.

Amasia, Sanjak of: 311.

--Town of: 154.

Ambassadors, Conference of, concerning Aegean Islands: 70 .

Ambelákia: 124.

America and American Citizens: see United States of America.

Amorion: 218.

Anatolia:--Allied control-officers in: 145-8, 153-4, 179, 186-7, 227, 270, 273;

Central and Eastern: 107, 110-14, 146, 186-7, 192, 213-14, 218, 220, 224, 237; Central Desert of: 59, 214, 217, $226 n, 231,238$; Cradle of Near Eastern Civilisations in: 11, 109-10, 332; Evacuation of, by Greek Army: 100, 299; Feudalism in East Roman: 110-14; French Zone in: 49-50, 567, 104, 214; Invasion of, by Russians (1916-18): 50, 191, 213; Italian 
Zone in: 51-2, 56-7, 151, 154, 161, 196-7, 201, $226 n$; Plateau of: VI. passim; Western: 17-18 (racial war in), 34-6 (Greek military occupation), 68-71 (Mr. Venizelo's claims), 73-4, 84, 107, 114-15, 122-4 (Modern Greek colonisation in), 140-5 (Turkish reprisals against Greeks in), Chapters V., VI., VII. passim.

Anatolia College at Marsovan: 154.

Anglo-Franco-Russian Rivalry with Germany in the East: 44, 46.

--French correspondence concerning the Franklin-Bouillon Agreement: 105.

--French Rivalry in the East: 3, 44-62, 80, 83-106, 153, 254-8.

--Russian Rivalry in the East: 44, 46.

Angora: 128, 154, 159, 162, 170, 179-180, 190, 218-19, 226 n, 231, 237-8, 243, $275,290,333$.

--Government: see Turkish National Government.

Anna Comnena: 7 .

Antioch, Ancient: 222.

Antwerp: 225.

Anzavur Bey Cherkess: 183-4.

Arab Empire, Ancient: 9, 22, 111, $194 n, 214 n, 267-8$.

Arab:--Nationalist Movement: 18, 45, 47-9, 55, 86, $105 n, 117,214$; Provinces of Ottoman Empire: 49, 55, 136, 145, 189, 207, 209, 212.

Arabia: 20.

Arabian Desert: 213-14, 224.

Aratos of Soloi (quoted by St. Paul): 364 . 
Archaeologists:--Austrian: 149; German: 65, 166 n; Western: 238.

Archipelago, Aegean: 123, $231 n, 325$.

Ardahan: see Kara-Ardahan-Batum District.

Argonauts: 216.

Aristion of Ancient Athens, Professor: $178 n$.

'Aristoménis and Gorgó, History of': 338.

Aristonikos of Ancient Pergamon: 223.

Armenia: $18,110 n$; see also Erivan, Republic of.

Armenian:--National Home: 95; Nationalism: 18; Patriarchate at Constantinople: 187; Vilayets of Ottoman Empire (Cossack colonies in): 50.

Armenians:--In Anatolia and Constantinople: 32-3, 130, 136, 176, 191, 206, 271, 30, 307-8, 310, 323; in Cilicia: 84, $104 n, 119,121$; in Russia, 50; massacred in 1895-7: 17, 27, 261; massacred in 1909: 265, $269 n$, massacred in 1915-22: 49, 140, 143, 191, 265-6, 276-7, 280, 284, 291, 312-13, 342, 354; British Government's Blue Book on Treatment of (Miscellaneous No. 31, 1916): 50, $266 n, 312 n$.

'Armenoid' Racial Type: 113.

Armistice of $11^{\text {th }}$ November 1918 with Germany: 262.

--of $30^{\text {th }}$ October 1918 with Turkey: $3,36,77-9,85,117 n, 131,145,151,153 n$, 168, 178, 181, 187, 189, 207, 209, 212, 256, 320, 353.

Armudlu (Yalova-Gemlik Peninsula): 143, 148, 269, 276, 286, 293-6.

Arnautkeui (Bosphorus): $180 \mathrm{n}$.

--(Yalova-Gemlik Peninsula): 282 n, 287, 296. 
Arnold, Professor Sir T. W.: $114 n, 267 n$.

Artemis of the Ephesians: 150.

Asia, Central: 111, 114, 203, 339, 342, $343 n$.

Assumptionist Brothers at Ismid, French: 298.

Assyria, Ancient: $213 n$.

Athenian Confederacy, Ancient: 220-1.

Athenians, Ancient: 220-1, 364.

Athens, Academy at Ancient: 336.

--Modern:--Armed conflict in ( $1^{\text {st }}$ December 1916): 67, 89; Dukes of: 38 ;

Government of Greek Kingdom at: 93, 98 n, 106 n, 163, 244 n; Holy

Synod at: 195; People of: 194, 242; University of: 173.

Athos, Mount: 333.

Atlantic Ocean: 334

Atrocities: passim.

Australasia: $134,334$.

Australians:--Blackfellows: 134; Whites: 134, 334.

Austrasian Franks: 29.

Austria (Proper): 43, 112, 130, 132, 189, 323; see also Hapsburg Monarchy.

--Hungary, see Hapsburg Monarchy.

Austrian Army: 257.

Austrians, German: 129, 132, 180.

Avghyn: 255.

Aya Sofía: 30, 336. 
Ayasoluk (=Modern Ephesus): 161.

Azaerbaijan, Transcaucasian Republic of: 42-3.

Bafra, District of: 289, 292.

--Town of: 289, 292.

Baghchejik (near Ismid): 292.

Baghcheshmé (Ismid): 298.

Baghdad: 56.

Baku: 42.

Balcha Ova (Aidin Vilayet): 169.

Balfour, Sir Arthur: 76.

'Balkanisation': 25-7.

Balkan Peninsula: 108, 110, 160-1, 194 n, 219, 221-3, 279.

Balykesry: 143.

Bantus: 334.

Bashkirs: 198.

Bashlamysh (Aidin Vilayet): 288.

Bash-Bozuks: 27, 279.

Basil II., East Roman Emperor: $110 n$.

Basques: $342 n$.

Basra: 213.

Bas-Reliefs, Ancient Egyptian: 113.

Batum: 257, 283 n; see also Kars-Ardahan-Batum District. 
Bavarians: 65 .

Bayndyr, District of: 290, 318.

Bazar Keuf: see Pazarkeui.

Beicos: 275.

Beirut: 56, 213.

Beirut, American College at: 256.

Bekir Samy Bey: 93 n, 94, $97 n$.

Belfast: 262.

Belgians and Belgium: 16, 26, 83, 225, 262, 275, 342.

Beneè, Dr.: 43.

Benghazi: 352.

Bergama, District of: $156 n, 161,170$.

--Town of: 123-5, 140, 143, 168, 227.

Bible: 119, 193-4.

Bigha, Peninsula of: 47, $57 n, 183$.

'Big Three' at Peace Conference of Paris: 78-9.

Bismarck, Prince: 4.

'Black and Tans': 262.

Blackfellows: see Australians, s.v.

Black Sea: 34, 59, 68, 150, 162, 194 n, 215, 283 n, 291, 313.

-- -- Riverains of: $48,71,92$.

Blockade, Naval, during European War: 26, 67.

Boars, Wild: 199. 
Bohemia: 112, 269.

Bohemians, German: 129.

Bolsheviks: see Revolutions, Russian and Russia, Soviet Government of, at Moscow.

Bosnia-Herzegovina: $211 n, 352$.

Bosniaks: 139.

Bosphorus: 71,78 .

Boz Oyuk: 248, 250-1.

Breslau, University of: $178 n$.

Bristol, Admiral: 78.

British:--Army: 20, 32-3, 86, 88, 154, 229 n, 235 n, 239, 252; Columbians: 134; Empire (including Great Britain): 31, 34-5, 40, 42, 117 n, 171, 174, 189$90,211 n, 254,348,352-3,360-1$.

Brooke, Rajah: 38.

Brusa: 10 (Green Mosque at), 115, 143, $157 n$ (Military Hospital at), 159 n, 216, 228-30, 232-6, 240-1 (Turkish officer prisoners at), 246, 249, 253-5, 256 (Military Hospital at), 294, 299, 317.

Brussels: $166 n$.

Bryce Reports: 80; see also Armenians, British Government's Blue Book on Treatment of.

Byrony, H.M.S.: ; 264, 285-6.

Buldur: 218.

Bulgaria: 18, 27-8, 43-4, 64-7, 69, 71-2, 96, 195, 239, 244, 323-4, 352. 
Bulgars: 44, 91, 110, $120 n, 129,136,138,161,176,323,342$.

Bureaucracy: 132.

Byzantine: see East Roman.

--Churches: 129, 150.

Californians: 134 .

Caliphate, Ottoman: 24, 28-32, 182-5, 208, 210, 352.

Caliphs, Arab: see Arab Empire, Ancient.

Calthorpe, Admiral: 78.

Calvinism: 8.

Capetian Dynasty of France: 110.

Capitulations: 94, 163, 189, 209-210, 321, 358.

'Cappadocia': 119, 124, 194.

Carnegie Endowment for International Peace: $138 n$.

Carolingian Dynasty: 11, 29.

Carpet-making: $170,355-6$.

Carthage, Ancient: 41.

Caspian Sea: 194 n, 213.

Catholic Church: 184, 329-330, 345.

Catholics, Roman: 26 (Irish), $118 n$ (Arabic-speaking), 132 (English), 262 (in Ulster).

Cats, Angora: 357.

Cattaro: 334 . 
Caucasia, Northern: 281.

Caucasus Mountains: 213, 224.

Cayster, River: 149, 161, 200-2, 229.

Chalyjakeui (Kaza of Yalova): 311.

Chamberlain, Mr. Austen: $97 n$.

Chanak Kalé (Dardanelles): 55, 184.

Charlemagne: 29 (sword and crown of), 268.

Charles, late ex-King of Hungary: 90.

Chatalja Lines: $68,71,138$.

Chengeller (near Gemlik): 284.

Cheshmé, Peninsula of: 333.

Chettés: 140, 156-7, 161, 183, 186, 200, 226 n, 230, 232, 234, 239, 258,

Chapter VII. passim, 278-280 (definition of).

Chibukli: 275.

Chicago: 28.

Chichérin, Mr. George: 178.

Childs, Mr. W. J.: 265.

China (Far East): 28 (Genoese overland trade with), 144 n, 342.

China (town in S. W. Anatolia): 196.

Chinese:--Moslems: 29; Emigrants: 134.

'Christendom': 74, 329.

Christian Church, Early: 328.

Christianity: 74, 90-1, 268, 327-31, 336, 346. 
Cilicia: 22, 49-51, 59, 84-7, 107, $110 n, 312-13,364$.

Cilician Campaign: see Wars, Franco-Turkish, in Cilicia.

Circassians: 130, 139, 156-7, $160 n, 171,183-4,227,281-3,288$.

'City, The' (=Constantinople): 61.

Classes, Relationships between social: 346-7.

Clemenceau, M. Georges: 76, 83, 86-7, 89.

Climatic Cycles: 114 n, 339-42.

Coal Strike in Great Britain (1921): 3.

Colonies:--Ancient Greek in Anatolia: 108, 220-2; Modern Greek in Western Anatolia: 122-4; Modern Greek in the West: 28, 345; Western in Constantinople: $144 n, 148,154$; Western in Smyrna: 122-3, 144 n, 148, 158, 165.

Colour Prejudice: $327 n$.

Commandments, Ten: 283.

Commissions of Inquiry, Inter-Allied:--At Smyrna (1919): 78-80, 151, 227, 270; In the Yalova-Gemlik and Ismid Peninsulas (1921): 169, Chapter VII. passim.

Commons, House of, at Westminster: $79 n, 86,97 n, 99$.

Conferences:--Berlin (1878): 40. 10; Boulogne (1920): 228, 232 n: Erzerum (1919): 187; London (1921): 3, 93-7, 133 n, 134, 198, 232-3; Paris (1919): 48 n, 67-78, 81-2, 86, 131, 133, 313; Paris (1922): $106 n, 244 n$, San Remo (1920): 227; Sivas (1919): 187; Vienna (1814): 45.

Confucianism: 330 . 
Conscription, Military: 18-19 (in Turkey), 360 (hypothetical, in India).

Constantine Dhraghasis, last East Roman Emperor: 342.

--King of Greece: Chapter III. passim, 67 (abdication of), 164, 180, 183, 232, 235, 243, $244 n, 315,322$.

'-Porphyrogenitus': 336.

Constantinople:--Allied High Commissioners at: 55, 179, 185, 188, 259 n, 287, 291-2, 312; Allied Occupation of: 32, 55, 57, 80, 153-4, 175, 182, 190, 227, 237, 242; American College for Girls at: 180; General refrences: 29, 30, 34, 38, 45, 47 (Russia to annex), 56, 61, 70-3 (Mr. Venizelos's policy regarding), 77, 89, 94 (contingent expulsion of Turkey from), 107, 108-9, $114,120,122,130,132,138,139$ n, 148, 153 n, 159, 162, 169, 172-3, 185-7, 194-5, 206, 208, 210, 243, 245, 254-5, 263, 296, 299, 301, 305, 307-8, 333, 336, 353; Greek High Commissioner at: 301, 307; Oecumenical (Orthodox) Patriarchate at: 8, 120 n, 187, 192-6,259, 294; Ottoman University of: 173.

Constanza: 34 .

Consulates (Western): 45, 58, 104, 158 n, 165, 290.

Copts: $117 \mathrm{n}, 118$.

Cordelió (Smyrna): $157 \mathrm{n}$.

Cossacks: $50,281,341$.

Costas: see Kostas.

Council of Ten at Peace Conference of Paris: 71.

--Supreme, of the Allies: 78-9, 226-7, 229, 232, 259. 
Crimea: 38, 89, 223, 225.

Croats: 44.

Cromer, Lord: 167.

Cross, Sign of the: $240,297-8$.

Crusade, Fourth: 7, 114.

Crusaders: 9, 11.

'Cuius regio, eius religio': 269.

Currant-culture: 123, 245.

Curzon, Lord: 106 n, 178.

Cyprus: 51, 64, 75, 211 n, 222 n.

Cyzicus, Ancient: 222.

Dagh Emir (near Aidin): 197-200.

Dalmatia: 126, 130.

Damascus: 55-6, 213.

Danube, River: 188, 248.

--Delta, Islands in the: $211 \mathrm{n}$.

Danzig: 126.

Dardanelles: 45, 56, 71, 184, 219.

--Expedition: 66, 179, 225, 233.

Darius (last King of the Achaemenid Dynasty): 204, 224.

Dark Ages:--Western and Near Eastern: 9, 108, 111, 127; Middle Eastern: 9, 115 n, 268. 
Dawkins, Professor R.M.: 119 n.

Deirmenderé (Gulf of Ismid), Skala and village of: $288,316$.

Democratic Control of Foreign Policy: 60.

Denikin, General: 83, 225.

Denizli, Sanjak of: 69.

Deportees: see Refugees and Deportees.

Derekeui (Kaza of Yalova): 311.

Deucalion: 334.

Dhimitri of Koiru: 294.

Dhraghúmis, late Mr. loánnis: 81.

Dijankeui (Kaza of Gemlik): 284.

Dikeli: 140, 143, 168.

Dispensary, Turkish, at Iki Cheshmelik (Smyrna): 176.

Dobrujalys: $139,194 \mathrm{n}$.

Dodekanese: $211 \mathrm{n}$.

Don, Genoese Colonies on River: 38.

Dörpfeld, Dr. W.: 65.

'Dorylaion': see Eski Shehir.

Downing Street: 39 .

Drachma, Exchange value of the Greek: 235, 244-5.

'Dragon's Teeth': 259.

Drang nach Osten (of the Hapsburg Monarchy): 4.

Druses: 45. 
Duma, Russian: 342.

Dúsmanis, General: 235.

Dutch dominion over non-Western civilised peoples: 29, 31, 106.

Dynasties:--of the Modern Kingdom of Greece: 65, 322; Ottoman Dynasty: 29, 182-3, 247.

Eastern Question: 1, 9, 41, 45, 76, 99, 255.

East India Company, British: 38.

--Indies, Moslems in: 29.

--Roman Empire: 6, 38, 109-16, 193, 194 n, 214 n, 218, 243, 332, 335-7.

Edhem Bey of Salyhly: 156, 171 n, 281.

Edirné: see Adrianople.

Education:--Modern Greek: 21, 33, 120, 124, 132, 172, 176, 245, 356; Turkish: 132, 171-7, 184; Volga Turkish: 356; Western in the East: 45, 104, 154, $176,180,182,184,190,359$.

Educational Commission, Turkish, in Smyrna Zone: 173-5.

Eftim (Efthýmios), Papa, of Keskin: 192-5.

Egirdir, Lake: 191.

Egypt, Ancient, Ptolemaie Great Power in: 41, 222.

--Modern: 11, 45, 86, 127, 166 n, 171, 174, 181, 190, 211 n, 213, 256, 348, 352.

Egyptian Civilisation, Ancient: 9, 22, 113, 222, 329, 363-4.

--Nationalism, Modern: 117 n, 118.

Eisner, Kurt: 262. 
Elections:--In Greece (November 1920): 68, 81, 244 n; in Turkey (1919-20): $153,187-8$.

Eliot, Sir Charles: $338 \mathrm{n}$.

Elmalyk (near Yalova): 284, 307.

Embassies: 32, 45, 58, 104, 279.

Emery mines in Greece: 245.

Eminé of Armudlu: 295.

Engheré (Yalova-Gemlik Peninsula): 282 n, 297.

England: 110-11, 178, 228, 299, 342.

Entente (Anglo-French): see Anglo-French Rivalry.

--Little: 43-4.

Enver Pasha: 179, 186, 191.

Ephesus: 10 (Great Mosque at), 120, 148-52, 161, 221.

Epirus: $164-6$.

Eregli (under Taurus): 218-19.

--(on Ismid Gulf): 288.

Erivan, Republic of: 42, 56 n, 107, 191, 313, 323-4, 326.

Ertoghrul, father of Osman: 114, 247.

Erzerum: 154, 218-19.

Eshref Bey of Sokia: 156, 171 n, 281.

Eski Shehir: 57, 98, 128, 159 n, Chapter VI. passim, 275, 278, 299, 315, 319.

Established Church, English: 132.

Euphrates, River: 224. 
--Railway Bridge over River, at Jerablus: 85.

Eurasia: 333.

Europe:--Concert of: 35, 279, 324; Continent of: 328, 332-4, 346; Wetsern: 9, 16, 28, 111, 128, 177, 202-3, 257, 334-5, 342 n, 359.

Evanyelikì Skholí at Smyrna: 124.

Evrenós. Family of: 115.

Fan Noli, Bishop: 195.

Far Eastern Civilisation: 330, 332, 359.

Feisal (bin Husein), Emir: 39, 60, 86, 118, 228.

'Felicity, Abode of': see Constantinople.

Ferid Pasha, Damad: 181, 183-5, 227, 281.

Finlay, George: $122 \mathrm{n}$.

Finns: 342 n, 355.

Firoz Shah of Delhi: $10 \mathrm{n}$.

Fisheries, North American: 46.

Fistikli (Yalova-Gemlik Peninsula): 286, 296.

Fistikli, villages round: 276, 282, 287, 293.

Fiume: 126.

Flags: 102.

Florence: 38.

'Forty-Five, The: $269 \mathrm{n}$.

France: 40, 42, 54, 128, 178, 189, 246-7, 254, 262, 269, 342, 348, 353. 
--Northern: 148, 275.

Franchet d'Esperey, General: 26.

Francis I. of France, King: 89.

Franco-British: see Anglo-French.

Frangópulos, Mr.: 166, 201-4.

'Franks': see Westerners.

Franz-Ferdinand, Arch-Duke: 262.

French:--Army: $86,88,239,241,252$; Bondholders: 77,321 ; Colonial Party:

76; Dominion over non-Western civilised peoples: 31, 34-5, 190, $211 \mathrm{n}$;

General Staff: 228-9, 232; Vice-Consul at Aivali: 143.

Frontiers:--Scientific: 224 ; Stabilisation of: $325-6$.

Fulajyk (Karamursal District): 284.

'Gaelic Question,' Absence of, in Twentieth-Century Great Britain: 269 n.

Gagauz: see Turks, s.v.

Galata: $37-8$.

--Serai Lycée: 173, 175.

Galatians, Ancient: 219, 222.

Gallipoli Peninsula:--Russia to annex: 47; Allied occupation of: 57 ; Turkish Nationalists raid munition dump on: 227.

Gamaliel, Rabbi: 181.

Gandhi, Mahatma: 359-61.

Gate, Golden: 253. 
Gaulis, Madame: 102.

Gauls, Ancient: 128.

Gedelik (near Gemlik): 296.

Gehri, M. Maurice: 259 n, 278, 284-5, 299-311, 317.

Gemlik, Gulf of: 284, 313, 315.

Gemlik, Town of: 103, 139, 229, 259, 264, 282, 284, 286-7, 292, 294-6, 302, $306,311,313,317 \mathrm{n}$.

Geneva, University of: 8.

Genoese, The: $37-8$.

Georgia (in Transcaucasia): 18, 42-3.

German:--Policy towards Turkey: 88-9, 343; Rivers: 188; Socialist Party: 25;

Ultimatum to Belgium: 83; Universities: 65, 112.

Germans: 112, 149, 176, 179, 224, 231 n, 241, 247.

Germany: 3 (Relations of, with Entente Powers in 1921), 40, 42, 65-6 (Debt of Greece to), 106, 114 n, 189, 225, 235, 323, 358.

Ghajyk (Kaza of Yalova): 306, 309-11.

Ghalaxidi: 124.

Ghunarákis, Mr.: $134 \mathrm{n}$.

Ghúnaris: see Ghoúnaris.

Ghuzz: see Turks, s.v.

Gibbon, Edward (quoted): 7.

Gibbons, Mr. H.A.: 114 n.

Glencoe, Massacre of: $269 \mathrm{n}$. 
'God, The Unknown': 364.

Gökje Deré (Kaza of Yalova): 311.

Gök Su (Tributary of River Sakkaria): 237.

--Tepé (Trans-Caspia): 342.

Gölde (near Kula): 119, 129.

'Golden Ages': 131, 351.

Golden Horde, The: 350 n.

--Horn, The: 38.

Gördez (near Akhissar): 318.

'Gordian Knot,' The: 128, 222.

Gordion, Ancient: 238.

Goths, Ancient: 128.

Göttingen, University of: 166.

Goúnaris, Mr.: 81, 83.

Graeco-Roman: see Hellenic.

Great Britian: see British Empire.

Greece:--European: 109, 118, 220-2, 241-2; Modern Kingdom of, Building up of: 15, 18, 26, 35, 66, 195, 348-9; Modern Kingdom of, Factions in: Chapter III. passim, 144, 163, 173, 195, 231, 242-4, 322; War-weariness in: 81, 243-6.

Greek Army:--Conscription of Ottoman Greeks for: 169, 205, 235 n. 239;

Eleventh Division: 288, 317 n; First Corps: 247, 317; General references: 20, 72, Chapters V., VI., VII. passim; Second Division: 231 n; Seventh 
Division: 233, 247-254; Sixteenth Infantry Regiment: 288; Tenth Division: 102-103, 239, 250-1, 295, 301, 306, 317 n; Third Corps: 235 n; Third Division: 254; Thirteenth Division: 231 n; Thracian Levie: 239; TwentyEighth Infantry Regiment: 286.

--Boy Scouts: 125, 1998; Censorship: 34; Corporate spirit: 124, 132; Merchant Marine: 244; National Assembly (1920-2): 94; National Defence Movement (1916-17): 67.

Gregorian Church: 118-19, 121; see also Monophysites.

Gregory the Great, Pope: 329.

Gryparis, Mr.: 81.

Gul-i-Nihal, Red Crescent S.S.: 263, 276 n. 287, 299-311.

Gurus, Indian: 360.

Haidar, Pasha (Asiatic suburb of Contantinople): 149, 184, 218.

-- -- Peninsula: see Ismid Peninsula.

Hajin (Cilicia): 312-13.

Hajji Mehmed Chiftligi (Kaza of Yalova): 307.

Halidé Hanum: 180.

Hapsburg Monarchy: 4-5, 25, 40, 129-130, 211, 214, 225, 269, 352, 358.

Haramein, The: 198.

Hardy, Mr. Thomas: 39, 361.

'Harmosts': 76, 177, 299.

Hashimite family, Sherifs of the: 30,47 . 
Headgear, Significance of: 204, 256-7, 272, 283, 309.

Hellen, on of Deucalion: 334.

'Hellene,' Name of: 336-7.

Hellenic Civilisation, Ancient: 5, 9, 22, 74, 76, 108-9, 117, 121, 128-9, 220-4, $328-9,334-8,346-7,363-4$.

--Literature, Ancient: 117, 329-30, 335.

Helvetian Republic: see Switzerland.

Hermus, River: 116, 151, 215, 229.

Herodotus: 52, $221 \mathrm{n}, 340 \mathrm{n}$.

Hijaz: 48-9, 52 n.

Hijazis: 30, 45, 213.

Hijjra of the Prophet Muhammad: 329.

Hilmi Reis of Armudlu: 295.

Hindu Civilisation: 11-12.

--Extremists: 322.

Hindus: 25, 261.

Hippocrateum, Corpus (quoted): $334 \mathrm{n}$.

Hittites: 113, 129.

Hohenstaufen Dynasty: 128.

Hoja-Bashys, Moreot Greek: 337.

Hoja Deré=Khoja Deré (Yalova-Gemlik Peninsula): 276, 296-7.

Hojas: see Islamic Ecclesiastics.

Homer: $29,339-40$ (quoted). 
Hospital at Smyrna, Turkish: $171,176-7$.

Hungary: 42-3, 189, 323.

Huns: $334,342$.

Huntington, Dr. Ellsworth: $340 \mathrm{n}$.

Hurriet: see Revolutions, s.v. Ottoman (1908).

Husein, Sherif of Mecca and King of the Hijaz: 47-9, 51.

Husni Bey, Mutesarrif of Manysa: $171 \mathrm{n}$.

Hyperion: 338.

Idrisi of the Yemen, The: 30 .

Ihsanié (near Fistikli): 293.

Iki Cheshmé (Turkish quarter, Smyrna): 157 n. 176.

Imperialism: 40, 357.

India: $10-11,35,38,45-6,115$ n. 163, 171, 174, 224, 343, 359-61.

Indian:--Army: 20, 86, 360; Emigrants: 134; Moslems: 29, 31, 57, 182, 261, 322.

Industrialism: 26, 341, 359-60.

Infanticide in Ancient Greece: 347.

In Önü, Battle of: $38,97,102,157$ n, 233, 235-6, 238-40, 242, 246-54, 275, 278, 295, 315-16.

Intermarriage: $28,241,345$.

'International, Green': 44.

Interpreters: $32-3,167,198,286,307$ 
Interregna between Civilisations: see Dark Ages.

Ionia, Ancient: 220-2.

'Ionia'=Smyrna Zone of the Treaty of Sèvres: 61, 76, 177, 220.

Ionian Islands: 202, 338.

Iraq: 11, 34, 59, 85, 190, 213-14, 225.

--Rising of 1920 in, against British military occupation: 55, 60, $230 \mathrm{n}$.

Iraqis: 29, 134.

Ireland: 3, 26, 112, 158, 167, 184, 262, 269.

Ironic, Spirit: 361.

Iskender Beg (=Scanderbeg): 338.

Islam: 12, 114, 222, 224, 257, 327 n, 328-332, 343, 353 (Fatalism incorrectly attributed to), 354-6.

Islamic:--Ecclesiastics: 132, 181-2, 184-5; Law: see Law, s.v. Islamic; Literature: 117, 329; Traditions: 269.

Islands, Greek: see Archipelago, Aegean.

Ismid, Gulf of: 162 n, 287-8, 292, 296.

--Peninsula and District of: 47, 55, 57 n, 242, 259 n, 274 n, 281, 285, 315.

--Town of: 162 n, 228-9, 230 n, 231, 240, 259, 274 n, 282, 287-8, 292, 297-8, $312 \mathrm{n}, 315-16,317 \mathrm{n}$.

Isnik, Lake of: $275,313,315$.

--Town of: 111, 275, 284.

Istria: 130. 
Italian:--Army: 20, 59, 226 n; City States, Mediaeval: 6 n, 37-8, 44; Delegation at Paris Peace Conference (1919): 77; Dominion over non-Western civilised peoples: 31, 42, 106, 211 n; Risorgimento: 185; Secret Service: 51.

Italy (and Italians); 126, 128, 229 n, 342, 352.

'Izzet Pasha: 185.

Jacobean Architecture: 37.

Janissaries: 10-11, 18, 183.

Japan: 353 n, 359 n.

Japanese Emigrants: 134, 334.

Jaurès, J.: 262.

Jemal Pasha (Colleague of Enver and Talaat Pasha): 186.

Jemil Bey (Turkish Nationalist Governor of Bafra, 1921): 289.

Jerusalem: 198.

Jews: 45, 173, 178, 189, 194 n, 261, 267, 271, 298, 364.

Joan of Arc: 128.

Joneseu, Mr. Take: 44.

Jonnart, M.: 67.

Jugoslavia: 18, 25-8, 43, 52 n, 176, 189, 244, 323.

Jugoslavs: 110 .

Jungle Book, The: 181.

Justinian, Emperor: 336. 
Kaiajyk (near Akhissar): 318.

Kaikos, River: 123.

Kaisaria: 143, 150, 219, 238, 241.

Kaloyerópoulos, Mr.: 94-5.

Kapaky (Yalova-Gemlik Peninsula): 285-6, 293, 295-6.

Kara Bekir Pasha, Kiazym, and his campaign against the Republic of Erivan (1920): 56 n, 257, 313.

Karait Jews: see Turks, s.v.

Karaja Ali (Yalova-Gemlik Peninsula): 293, 295-6.

Karakeui Defile: 232, 247, 250-1, 253.

Karakilissé (Kaza of Yalova): 311.

Karaman, Principality of: 119, 124.

Karamanly Orthodox Christians: 33, 119 n, 120, 157 n, 194.

Karamursal, Peninsula of: see Yalov-Gemlik Peninsula.

--Town of: $288,315 \mathrm{n}, 316$.

Karatepé (Aidin District): 319.

Karatheodhorís, Professor Constantine: 166, 168.

Kars, Town of: 257.

--Ardahan-Batum District: 56-7, 75 n, 188, 208-9, 211 n.

Kasaba, District of: 290.

Katyrly (Yalova-Gemlik Peninsula): 282 n, 287, 294, 296.

Kavala: 69.

Kazaks, Kirghiz: 114 n, 342. 
Kazan Tatars: see Turks, Volga.

'Kemalists': see Turkish Nationalist Government and Movement.

Kerensky, Mr.: 342.

Keskin (in South-Central Anatolia): 192.

Khadija of Karamursal: 288.

Khairié (near Fistikli): 287, 293.

Khilafat Movement in India: 24, 28, 32, 182.

Khios: 17, 38, 70, 130, 140, 143.

Khorofilaki (=Gendarmerie) in Anatolia, Greek: 166-7, 299.

Khosru Nushirwan, Shah: 336.

Khristo of Hajji Mehmedin Chiftligi: 307.

Kristo of Katyrly, Taukju oghlu: 294-5.

Kiatyb oghlu (Smyrna): $157 \mathrm{n}$.

Kilisman (near Smyrna): $157 \mathrm{n}$.

Kinik (near Bergama): 123, 143, 168.

Kirazly (Kaza of Yalova): 311.

Kiresün (=Kerasund): 156, 289.

Kirkinje: 120, 124.

Kiutahia: 98, 236-7, 319.

Klagenfurt: 188.

Klazomenai: $222 \mathrm{n}$.

Klephts: 279, 338.

Klionas, Mr.: 168. 
Knidos, Peninsula of: 333.

'Knock-out Blow': 212, 224.

Kocho of Armudlu, Mumju oghlu: 295.

Koiru (Yalova-Gemlik Peninsula): 294.

Kolchak, General: 83.

Kolokotrónis, Theódhoros: 337-8.

Komitajys: 161, 279.

Kömürderé (near Smyrna): $157 \mathrm{n}$.

Konia: 52, 119, 218-19, 231, 241, 256.

Konstandínos Porphyroyénnitos: see Constantine, s.v.

Koraís, Adhamándios: 9, 332, 335, 337-8.

Koressos, Mount (above Hellenistic Ephesus): 149, 151.

Köshk: 291, 319.

Kostas, Lieut. Ioánnis, of $28^{\text {th }}$ Greek Infantry Regiment: 286-7.

Kosti of Constantinople: 307.

--of Elmalyk: 307.

Koumla: see Kumla.

Kovalyja (=Kovalitsa): 233 n, 248-250, 252, 255, 257.

Kozak, The (north of Bergama): $156 \mathrm{n}$.

Kretan 'Special Constabulary' at Athens (1920): 81.

Krete: 37, 67, 96, 163, 197.

Kula (Aidin Vilayet): 120, 123, 128, 150, 170, 290.

Kum Kale (Dardanelles): 219. 
Kumla, Kuchuk (Yalova-Gemlik Peninsula): 264, 285-6, 296.

Kurdistan:--Hypothetical Government of: 53, 95; Western: 50.

Kürdkeui (Kaza of Yalova): 311.

Kurds: 85, 104 n, 136.

Kurujus, Greek, in Turkish villages: 278, 294-5, 302.

Kush Adasy: see Scala Nuova.

Kutu'l-Amara:--British prisoners from: 142; Seige of: 228.

Kydhoniés: see Aivali.

Kyrillos, Oecumenical Patriarch: see Lukaris, Cyril.

Kyrkagach (Aidin Vilayet): $157 \mathrm{n}$.

Kyzylja (near Smyrna): 319.

Kyzyl Yrmak ('Red River'=Ancient Halys): 119.

Labrador Indians: 127.

Lancashire: $359-60$.

Lane-Poole, Mr. Stanley: $10 \mathrm{n}$.

Languages:--Arabic: 4, 117-18; Armenian: 118-19; English: 112, 249; Flemish:

111; French: 4, 111-12; German, High: 4, 112; Greek, Ancient: 20-1, 109, 194, 335; Greek, Modern: 20-1, 109, 113, 119-20, 123-4, 167, 249;

Indo-European: 342-3; Iranian, Modern: 343; Latin: 109; Near Eastern vernacular: 8-9; Oriental, Department of, in new Greek University at Smyrna: 168; Prakrit, Modern forms of: 4, 343; Pre-Greek in Anatolia: 108, 129, 204; Sanskrit: 343; Syriac: 117; Turanian: 342 n, 343; Turkish: 
117, 119-20, 123-4, 129, 166-7 (ignorance of, among Greek gendarmerie in Anatolia), 192-4; Western, Modern, taught in English schools: 4.

Lapps: $342 \mathrm{n}$.

Law:--Islamic: 184 n, 267, 329; Roman: 329.

Laz (nationality): 283 n, 309.

League of Nations: 94-5, 326-7, 362.

Lebanon: 45, 96.

Légion d'Orient, French: 51, 118, 121, 312.

'Legitimate Warfare': 170, 260-1.

Lenin, Mr.: 83.

Leonardhópulos, General: 264-5, 284, 286, 299-311.

Leonidas, King: 347.

Levant, The: 40, 45-6, 76, 267.

Lewis guns: 151.

Liautey, General: 167.

Liebknecht, Karl: 262.

Liége, University of: $166 \mathrm{n}$.

Liman von Sanders, General: $144 \mathrm{n}$.

Lincolnshire: 215.

Liquorice: 170.

Lira:--Italian: 244; Turkish: 245.

Liutprand of Cremona, Bishop: 7.

Liverpool: 28. 
Lloyd George, Mr. David: 73-80, 86-7, 89-91, 94, 96, 98-9, 178, 181, 228-9, 313. Lombardy: 130.

Londi Kaptan of Engheré: $282 \mathrm{n}$.

London: 28, 34, 104, 151, 178, 244 n; see also Conferences and Treaties, s.v. Lords, House of: $106 \mathrm{n}$.

Lukaris, Cyril: 8.

Lutfié (near Fistikli): 293 n.

Luxemburg, Rosa: 262.

Lybyer, Professor A.H.: $10 \mathrm{n}$.

Lydia, Ancient Kingdom of: 220, 222.

Lydians, Ancient: 116, 129, 204.

Lysimachus (General of Alexander the Great): 149, 150, 152.

Macedonia, Ancient Kingdom of: 41, 222.

--Eastern: 65, 67, 69.

--Modern: 17-18, 27, 70, 115, 129, 140, 145-6, 160-2, 242, 246, 276, 279, 332.

--Western: 243.

Mackensen, General: 26.

Madras Presidency of India: 24.

Maeander, River: 57, 116, 123, 151-2, 170, 196, 198, 200, 202, 215-16, 226 n, 229, 242, 274.

Magyars: $176,342$.

Mahmud II., Sultan: 18, 45, 183, 344. 
Malaria: 168, 238.

Malatia: $110 \mathrm{n}$.

Malta: 38, 153.

Maltaise, Prison in Rue (Smyrna): 204-7.

Manchester: 28.

Mandated Territories: $34,55,57,86$.

Mani, The (in the Peloponnese): 336.

Manysa, District of: 289-90, 318.

--Town of: 95 n, 142, 148, 171 n, 226-8.

Marash: 86.

Margoliouth, Professor D.S.: 267 n.

Marmara, Sea of: $33-4,47,56,69,102,121,142,208,210,216-18,228,260$, 263, 315-17.

Maronites: 45.

Marseilles: 28.

'Mars Hill' (=Areopagus): 364.

Marsovan: 154, 277, 289, 297.

Marx, Gospel according to: 351 .

Masaryk, President: 39, 178 n, 181, 185.

Massacres: passim.

Masséras, Andréas (Private in Greek Army): 288.

Masuria: 188.

Mecca: 30, 198, $329 \mathrm{n}$. 
Mediation in Anatolian War by Western Powers: 93-8, 101, $106 \mathrm{n}$.

Medina: $198,329 \mathrm{n}$.

'Mediterranean' Racial Type: 119, 122.

--Sea: 41, 215, 223, 333.

Mehmed Ali, Pasha of Egypt: 15, 45, $211 \mathrm{n}$.

Mejidié (near Fistikli): 293.

Mesopotamian Civilisation, Ancient: 9, 22, 222, 329, 363-4.

Mesopotamia, Modern: see Iraq.

Messana, Ancient: 41.

Mestrius Florus, L., Proconsul of Asia: 150.

Middle Ages, Near Eastern and Western: 128.

--Eastern Civilisation defined: 9-14.

Midhat Pasha: 190.

Mihal of Hajji Mehmedin Chiftligi: 307.

Millet-i-Rum: see Rum Milleti.

--System: 135, 173, 267-8.

Minorities:--Economic basis of: 16, 126-7, 146-8; German: 25, 176; Intermigration of: 70-1, 141-2, 146-147; Magyar: 25, 176; Moslem: 27; Protection of: $53-4,71,90-1,104-5,127,130,137-8,188-9,192,208$, 210, 241, 321, 322-7; Treaties concerning: see Treaties, s.v.

Missionaries:--Catholic: 8, 38, 45, 104, 298, 344; Protestant: $38,45,104,119$, $344,359$.

Mithridates of Pontus, King: 223-4. 
Mitylini: $70,125,130,140,143,166 \mathrm{n}$.

Modus Vivendi between different civilisations: 14, 31, 36, 177, 190, 321-2, 345, $357,361-4$.

Mogul (=Moghal) Dynasty: 10 n, 45.

Moldavia: 96.

Mongol:--Confederacy: $350 \mathrm{n}$ : Dynasty in China (=Yuen): 330.

'Mongoloid' Racial Type: 113, 119.

Mongols: $115,334,340-1$.

Monophysites: 268, 328-9; see also Gregorian Church.

'Monroe Doctrine': 359.

Montpellier, University of: 335.

Moplahs of Madras Presidency: 24-5.

Morea: see Peloponnese.

Moriscos of Spain: 267.

Morocco, Sherif of: 29.

Moscow: 44.

Mosul: 45, 76, 86 .

Mowgli: 181.

Mudania, Gulf of: see Gemlikk, Gulf of.

--Town of: 218, 229.

Mughla (S.W. Anatolia): 196, 216-17.

Muhammad, The Prophet: $329 \mathrm{n}$.

--(Mehmed) II. Fatih, Sultan: 10. 
--Ghori: $10 \mathrm{n}$.

Museum, British: 178.

Mustafa Kemal Pasha: 39, 178-81, 187, 223, 247, 255, 333.

Mykáli, Cape: 333.

Mysians, Ancient: 219.

Nabi Bey, Representative of the Sublime Porte at Paris: 101.

Nabúris, Mr. I. A.: 166 n.

Nantes, Revocation of the Edict of: 269.

Napoleon I., Emperor: 39, 45, 338.

Narly (Yalova-Gemlik Peninsula): 293, 295-6.

--Deré (Aidin Vilayet): 169.

Nationality, Western idea of political: 4, 15-18, 25, 90, 117-18 (in Syria), 118-48

(in Anatolia), 158, 190, 195, 212, 243, 268, 321-3.

Navarino, Battle of: 349 .

Navies:--British: 35, 74, 88, 99, 103, 121, 143-4, 147, 229, 235 n, 270, 272 n,

349; French: 35, 59 and 77 (mutiny in), 88, 229 n, 298, 349; Greek: 229, 245, 287, 291

Nazyf Pasha (near Brusa): 247, 253-4.

Nazylly (Aidin District): 123, 290.

Near Eastern Civilisation defined: 5-9.

Negroes in United States, Lynching of: 261.

Nestorians: $268,323-9$. 
Neutrality, Declaration of, by Allied Powers (1921): 315.

--Greek, in European War: Chapter III. passim.

New World: 334.

--York: 28.

--Zealanders: 134.

Nicaea: see Isnik.

Nidher, General: $235 \mathrm{n}$.

Nif, District of (Sanjak of Smyrna): 290.

Nihad Reshad Bey, Dr.: $134 \mathrm{n}$.

Nile, Basin of River: $35,45$.

'Noble Liies': 194.

Nomadism, Central Asian: 9, 10-11, 111, 113-14, 203, 223, 268, 331, 334-335, 338-344, 354-6.

Nonconformists, English: 132.

Non-co-operation: 60, 357-61.

'Nordic' Racial Type: 119-20.

Normans: 7, 110-11.

Norway: 202.

Ödemish, District of: 290, 318.

--Town of: 171 n, 227.

Odessa: 77, 202, 225, 245.

Olive-culture: 122-5, 151, 203, 245. 
Olmsted, Frederick Law: $338 \mathrm{n}$.

Olympian Gods, Cult of the: 336 .

Olympus, Mysian Mt.: 216, 249, 253.

Ömer Bey (near Gemlik): 103, 292, 313-19.

--Efendi of Köshk, Sultanhissarly oghlu: 291.

Orange-culture in Greece: 245.

Orphanage at Smyrna, Turkish: 168.

Orta Burun (Kaza of Yalova): 311.

Orthodox Church: 6 (overshadowed by East Roman Empire), 8 (Snynod of 1691), 20, 113-14, 118-21, 128, 161, 192-6 (Turkish-speaking adherents of), 329, 338 (Book of Offices and Chant-Book of), 355-6.

Osman Ertoghrul oghlu, Emir: 114, 247.

--Agha Kiresünlü: 156, 277, 289-290, 297.

Otto of Greece, King: 166 n.

Ottoman Army: 18-20 (Westernisation of), Chapters V., VI., VIII. passim.

--Caliphate: see Caliphate, s.v.

--Empire: 9-12 (institutions of), 15, and 18 (crisis of 1774-1841), 42, 45, 95-6 (autonomy in), 115-17 (rise of), 182-6 (political parties in), 338 n. 343-4, 355 n, 356.

-- -- Intervention of, in European War: 64, 141.

--Parliament: 135, 153, 187-8, 190, 207, 209.

'Ottomanisation': 135.

Oxford, University of: 66 . 
Pacific Ocean: 3.

Paduah, Universitiy of: 8.

Paederasty in Ancient Greece: 347.

Palestine: 34, 38, 45, 55, 86, 118, 190, 213.

--Lord Allenby's victory in (1918): 85, 87, 230 n, 256.

Pamirs, The: 149 .

Panayoti of Arnautkeui, Hajji Topuz (?) oghlu: $282 \mathrm{n}$.

Panderma: 216, 228.

Pan-Islamism: 241, 358.

--Turanianism: 42, 180, 214, $355 \mathrm{n}$.

Papagrigoríu, Captain Dhimítrios: 299-311.

Papoultópoulos, Adjutant (28 ${ }^{\text {th }}$ Infantry Regiment of Greek Army): 286.

Papulas, General: 222, 304.

Paradise Lost: 347.

Paris: 28, 34, 104, 136, 262 (Commune of, in 1871), 335.

--University of: 66, 202.

Parthia, Ancient: 224.

Pashakeui (Kaza of Yalova): 311.

Patriarchate at Constantinope, Oecumenical: see Constantinople, s.v.

Paul, St.: 364.

-- -- Prison of': 149.

Pawns, Small Powers used as: 61-2, Chapter III. passim. 
Pazarjyk (near Brusa): 247, 250-1, 253, 255.

Pazarkeui (near Gemlik): 284, 296, 311.

Peloponnese: 109, 114-15, 122, 124, 242-3, 325, 336-7.

Peloponnesian Governments, Ancient: 220.

Pergamon, Ancient Kingdom of: 41, 222-3.

Pericles: 29, 128, 221.

Persia: 11, 29, 30, 46, 194 n, 213, 343, 359.

--Anglo-Russian Agreement concerning: see Treaties, Anglo-Russian (1907).

Persian Empire, Ancient: 216, 220-2.

--National Movement, Modern: 214.

Persians: 188.

'Personal Statute': $120 \mathrm{n}$.

Pertev Mehmed Pasha Jamy’sy (Ismid): 298.

Peter the Great, Tsar: 8.

Petrograd: 44, 48, 245.

Pétses: 124.

Phanariotis: $166 \mathrm{n}$.

Philhellenism: 28, 139, 177, 240, 245, 305, 338, 355.

Philologists, Western: 343.

Philosophers, The Seven Last Ancient: 336.

Phokiés: 143 n, 169.

Photo of Imraly, Papa (Orthodox Priest of Armudlu): 294.

Phrygian Kings, Citadel and Sepulchres of Ancient: 218. 
Phrygians, Ancient: 113, 116, 129, 204, 219.

Picot, M. Georges: 48.

Pilsudsky, General: 39.

Pitt, The Younger: 39, 64.

Pius IX., Pope: 185.

Plato: 10, 194, 336.

Plebiscites: 164, 188, 208-10.

Poland: 42-3, 89, 148, 176, 189, 214, 261, 323.

Poles: 44, 112, 245.

Polytechnique at Smyrna, Turkish Ecole: 171, 174, 177.

Pompeii: 204.

Pompey the Great: 223-4.

Pontus, Ancient: 223-4.

'Pontus,' Modern Greek Nationalism in: 119, 154, 156, 190, 192, 275, 289-01, 311-3.

Poona: 360 .

Porte, Sublime: 93, 100, 106 n, 154, 172, 179, 181, 183, 185, 187, 208, 210, 259.

Potti (?Photi) of Arnautkeui, Kumarjy oghlu: $282 \mathrm{n}$.

Prag, University of: $112,178 \mathrm{n}$.

Princeton University: $178 \mathrm{n}$.

Prisons at Smyrna, Greek: 169, 204-7.

Professors in Politics: 178. 
Propaganda: $28,344-5$.

Protestant Universities: 8.

Protestantism: 262 (Ulster), 269 (Hungarian and South German), 327 n (American), $328 \mathrm{n}$ (Near and Middle Eastern), 330 (Reformation).

'Proto-Aryas': $343 \mathrm{n}$.

Prussia, Kingdom of: 40, 214, 269.

Prussians, Old: 268.

Psalter: 338.

Quai d'Orssay: 39, 105.

Qur'an: 198, 267.

Rahmy Bey, Ex-Vali of Smyrna: 175.

Railways:--Aidin (=Ottomman) [British]: 58 n, 123, 170, 191, 202, 213, 215-16, 226, 274, 319; Anatolian [German]: 232, 247, 251; Baghdad [German]: Anatolian: 217-19, 230-1, 232 n, 236; General, in Anatolia: 145, 154, 215, 218-19, 231; Iraq, Built by the British Army in: $213 \mathrm{n}$; Kasaba [French]: 123, 213, 216, 226; Oriental [Austrian]: 34, 243; Panderma Branch of Kasaba: 216, 228, 230; Syrian [French] 213; Trans-Caspian [Russian]: 341-2; Trans-Siberian [Russian]: 333; Trans-Turkestan [Russian]: 333.

Rakí: 296.

Rawlinson, Colonel: 154. 
Rayah: 11, 30, 268.

Record Office, British Public: 73.

Red Crescent Society, Ottoman:--Constantinople Branch: 139; Mission of, to S.E. coasts of the Sea of Marmara: 33, 102, Chapter VII. passim; Smyrna Beach: 176.

--Cross at Geneva, International Committee of the: 259 n, 278, 284-5, 299, 306.

--Indians: 134.

--Sea: 197.

Reform Bill of 1832: 66.

Refugees (and Deportees):--Alien, from East Coast of Great Britain: 144; Armenian (1915): see Armenians massacred in 1915-22; Cilician (19212): 242, 312 n; Greek from East Roman Empire: 335; Greek from 'Pontus': see 'Pontus,' Modern Greek Nationalism in; Greek from Western Anatolia: 122, 133, 140-6, 167-8; Kretan Moslem: 120, 139, 171, 281; Ottoman Ministry of: 138-9, 140 n, 169, 191; Rumili Moslem: 138-40, 144-6; Turkish from Anatolia: 133 n, 139, 168-9, Chapter VII. passim; Turkish from Constantinople (March 1920): 153-4, 227.

Relativity: $14,345,350$.

Renaissance, The: 330 .

Renegades: 115.

Reparations, German: 3, 76.

Reshadié (Kaza of Yalova): 284, 311. 
Revolutions:--English “Glorious” (1688): 269 n; French (1788 seqq.): 183, 262, 265, 337-8; Industrial: 359-360; Ottoman (1908): 131, 186, 190, 202, 269 n, 352-3; Russian Bolshevik (1917): 46, 154, 183, 202, 351; Russian Liberal (1917): 48, 342.

Rhine, River: 112, 188.

--Frontier, The: 76.

Rhodes, Cecil: 38.

--Island of: $38,41,222$.

Rif'at Bey, Kaimakam of Alashehir (1921): 290.

Riga: 334 .

Riza Tewfik Bey, 'the Philosopher': 181, 185-6.

Roman Empire: 9, 11, 41, 116, 128, 221-4, 268.

--Senators: 337.

Rome: 106 n, 151.

'Romyi' (=Rum): 130, 194, 336.

Ross, Ludwig: $166 \mathrm{n}$.

Rum: 31, 130, 194.

Rumania: 18, 25-8, 43, 64, 176, 189, 195, 244, 323.

Rumans: 44, 110.

Rumelia: see Rumili.

--Eastern: 96.

Rum Melleti: 120, 122 n, 130.

Rumili: 120, 124, 129-30, 146, 179,m 195, 212, 332, 352. 
Rupel, Fort: 67.

Russia:--General: $6,38,40,42-3,48,110,114 \mathrm{n}, 127,148,195$ (secession of Orthodox Church in, from Oecumenical Patriarchate), 204, 211, 214, 21819, 223, 225, 239, 245, 261, 262 n, 281, 313, 321, 333 (Russia in Europe and Asia), 341-2 (Expansion of, over nomad pasture-lands), 348, 350-1 (attitude of, towards the West), 353 n, 355-6, 362; Soviet Government of, at Moscow: 23, 48, 59, 76, 89, 92, 190, 214, 225, 245; 'Times of Trouble' in: 351.

Russian:--Literature: 350-1; Moslems: 29, 42, 355-6; Music: 350; Muzhiks: 342; 'Whites': 89, 225, 245.

Russo-British: see Anglo-Russian.

Russo-Turkish Entente (1920-2): 23-4.

Saar, Basin of River: 76.

Sabahu'd-Din, Prince: 181, 185.

Sadyk Bey (Turkish Nationalist Commissioner at Marsovan in 1921): 277, 289.

Saguntum, Ancient: 41.

St. Davids, Lord: 158 n, 319.

--John, Order of: 38.

Sakkaria, River: 57, 98, 192, 237, 239, 242, 315, 319.

Sakkaris, Mr. G.: $121 \mathrm{n}$.

Salisbury, Lord: 40.

Saljuqs: see Turks, Saljuq. 
Salonika: 45, 67, 109, 129, 130, 143, 167, $194 \mathrm{n}$.

--Expedition (1915-18): 66-7, 82, 225, 236 n, 239, 252.

Salyhly, District of: 290.

--Town of: 123, 173 n, 201.

Salzburg, Prince Bishop of: 269.

Samanly (Kaza of Yalova): 293-4, 301-5, 311.

--Dagh: see Yalova-Gemlik Peninsula.

Samos: $96,123,130,140,166 \mathrm{n}$.

Samsun, Sanjak of: 311.

San Francisco: 28.

San'a, Imam of: 29.

Sanhedrin, Ancient Jewish: 181.

Sapaunjoghlu, M. (French Vice-Consul at Aivali): 143.

Saraikeui-on-Maeander: 216.

Sarukhan, Principality of: 116.

Sary Su (tributary of Maeander): 200.

Satan, Miltonic: 347.

Saxons, Old: 268.

Scala Nuova (=Kush Adasy): 161 n, 226 n.

Scheldt, River: 188.

Schliemann, Heinrich: 65.

Scientists, Ancient Greek: 333-4.

Scotland: 359 . 
Scots: 188.

Scripts, Armenian and Greek: 119-20, 129, 193.

Scutari (suburb of Constantinople): 180 n, 310.

Scythians: 334 .

Seely, Major-General: $97 \mathrm{n}$.

Seleucidae, Ancient Empire of the: 41, 222.

Self-determination: $188-9$.

Selimié (near Fistikli): 287.

Senusi Fraternity: 30.

Seraglio Point: 310.

Serbia: 64, 67 (Treaty with Greece), 96, 148, 195 (secession of Orthodox Church in, from Oecumenical Patriarchate).

Serbian Army: 20.

Serbs: 44, 129, 136, 138, 161.

Serres: $194 \mathrm{n}$.

Shamanism: $144 \mathrm{n}$.

Shanghai: 37.

Sheikhu'I-Islam, Fetwa of Ottoman: 184-5.

Shere Khan: 181.

Shìis: 9, 29.

Shukri Efendi Chiftligi (Kaza of Yalova): 311.

Siciliy: 110.

'Sick Man of Europe,' The: 96. 
Silesia: 3, 26, 112, 188, $231 \mathrm{n}$.

Sillé (near Konia): $119 \mathrm{n}$.

Simav: 150, 216-18, 228.

Sindaghmatarkhs (=Bimbashys): 299.

Sinn Feiners: 262.

Sivas: 218-19, 238.

Slavophilism: 351.

Slavs, Migrations of the: $109,336$.

--Spread of Near Eastern Civilisation among the: 11.

Slovenes: 44.

Smyrna:--City and Zone of: $34,52,56,64,70,76-7$, and thereafter passim; Landing of Greek troops at (15 ${ }^{\text {th }}$ May 1919): $17,35,78-80,83-5,92-3$, $107-8,130-1,133,145,148,151,153-4,164,168$ n, 173-4, 179, 183, 186-7, 226, 232 n, 244 n, 265, 270-3, 276, 298, 312; New Greek University at 166, 173, 175; Orthodox Metropolitan Bishop of: 271 ; Local Parliament prescribed for: $155,164,172$; Statistics of population in: 93 , 133-4.

Soap-making: $122,151,355-6$.

Sofia: 35 .

Soghanderé District (Aidin Vilayet): 318.

Sokia: $226 \mathrm{n}$.

Soma: $166 \mathrm{n}$.

'Souls, Women and Negroes have no': 327. 
Soviet Government of Russia at Moscow see Russia, s.v.

Söyüd: 217, 219, 247.

Soyuljak (near Yalova): 284.

Spain: 40, 267.

Sparta, Ancient: 177 n, 221, 364.

Sperkhiós, River: 242.

Stambolisky, Mr.: 39, 43.

Stamboul: 132, 263.

Steffens of Breslau, Professor: $178 \mathrm{n}$.

Sterghiádhis, Mr.: Chapter V. passim, 272.

Strabo: 150.

Straits, Black Sea: 34, 46-7, 70-1, 74, 76, 87, 188, 208, 210, 219, 227-9.

--Command of, by Allied Navies: 55, 91, 145, 153 n; Commission of: 94; Zone of: $47,70-1,94$.

Sratighos, $\mathrm{X}: \mathrm{:} 237 \mathrm{n}$.

Struma, Valey of River: 69.

--Stürgkkh, Count: 262.

Stylianós of Arnautkeui: 294.

--of Katyrly (? identical with the above): $282 \mathrm{n}$.

Styrians: 129.

Sudan, Egyptian: 45.

Suez, Isthmus of: 45.

--Canal: 213. 
Suleiman the Magnificent, Sultan: 183.

--of Tiré, Isbartaly Hajji: 291.

Sultan of Turkey, H.M. the reigning: 181-2.

Sultanié (near Fistikli): 187, 193.

--(Kaza of Yalova): 311.

Sultaniyyah (Sultanié) School at Smyrna: 171-7.

Sunium, Cape: 333.

Sunnis: 29.

Susa, Ancient: 220.

Sweden: 40.

Switzerland: 16, 202, 237.

Sword, Knights of the: 268.

Syghyrjyk (Kaza of Yalova): 311.

Sykes, Sir Mark: $48 \mathrm{n}$.

--Picot Agreement: see Treaties, Anglo-Franco-Russian (1916).

Syphilis: 168.

Syra, Island of: 34 .

Syracuse, Ancient: 41.

Syria: $11,34,55,57,60,74,84-7,104,110$ n, 117-18, 190, 213-14, 224, 228, $281,359$.

Syrians: 30,45 .

Taghmatarkhs (=Yuzbashys): 299. 
Taj Mahal (at Agra): 10.

Talaat Pasha: 186, 191.

Talents, Parable of the: 134 .

Tarsus, Ancient: 364.

Taurus Mountains: 213.

--Tunnel: 214, 218.

Taxpayers: 59, 84 .

Techecho-Slovakia: 43, 176, 189, 323.

Tchechs: 44, 112, 132, 181.

Tekké, Deserted (in Cayster Valley): 201.

Telegraph Company, Eastern: 305.

Tepé Keui (near Torbaly): 201-3.

Tepékhané (Ismid): 298.

Terror, French: 262.

Teutonic institutions: 11.

Tewfik Pasha (Grand Vizier): 185.

Theism: 330.

Theophilus, Emperor: $194 \mathrm{n}$.

Thessaly: 132, 202.

Thomas of Elmalyk: 307.

Thrace, Eastern: 17, 27, 34, 56, 68, 73 76, 82, 93, 95, 109, 133 n, 139 n, 194 n, $222,228,332$.

--Western: 68-9, 71, 73, 76, 82, 109, 188, 208, 210, 332. 
Thucydides: 29, $221 \mathrm{n}$.

Tigris, River: 85, 213.

Times Correspondent at Contantinople: 39, 100-1, 192, 237 n, 277 n, 289 n.

Timur Lenk (=Tamerlane): 116.

Tiré, District of: 290, 318.

--Town of: 161, 198-201, 291.

Tisza, Count: 262.

Tiyenli (Aidin Vilayet): 289.

Tobacco-culture in Greece: 245.

Tolstoy, Leo: 198.

Torbaly (Cayster Valley): 161, 168, 202, 290.

Tralleis: 196, 216.

Transcaucasia: 43, 50, 56 n, 59, 74, 110, 118, 145, 211 n, 213, 218-19, 313.

Treaties:--Alexandropol (1920): 56 n; Anglo-Franco-Russian concerning Constantinople (1915): 47-8, 54-6; Anglo-Franco-Russian concerning Asiatic Turkey (1916): 48-51, 53-86; 214: Anglo-Russian concerning Persia (1907): 46, 53-4; Berlin (1878): 75 n, 145, 279, 332, 352; BrestLitovsk (1918): 25; Bukarest (1913): 141; Cyprus Convention (1878): 75 n; Franklin-Bouillon Agreement (1921): 54, 56-7, 60, 84-85, 89, 101, 1045, 178; Kars (1921): 56 n; Kuchuk Kainarjy (1774): 13, 30, 321; London (for pacification of Greece, 1827): 348 n; London (Protocol of 1830): 349; London (Convention of 1832): 65 n; London (Agreement between Entente Powers and Italy, 1915): 51; Minorities, Treaties concerning protection of: 
323; Moscow (1921): 56 n; Saint Jean de Maurienne (1917): 51-3, 56-7, 77; San Stefano (1878): 75 n; Sèvres (Tripartite Treaty of, 1920): 50, 524, 104; Trianon (1920): 43; Versailles (1919): 25, 90.

Trebizond, Town of: 50, $283 \mathrm{n}$.

--Vilayet of: 311.

Trentino: 130.

Trieste: 28, 126, 130.

Tripoli (North Africa): 211 n, 352.

Troad: 216, 228.

Trotsky, Mr.: 83.

Trumbie, Dr.: 185.

Tsardom, Russian: 92, 214, 342.

Tulu Punar (near Ushaq): 234, 236.

Tundras: 333.

Tunis: $211 \mathrm{n}$.

Turcification of Anatolia: 111-17, 220.

Turcophilism: 28-32.

Turco-Russian: see Russo-Turkish.

'Turk, The Unspeakable': 327 ('incapable of progress'), 334.

Turkey: see Ottoman Empire.

Turkish Army: 94, 123 n, 142, 153, 156, 157 n, 188, 205, Chapters VI. and VII. passim, 237 n (strength of), 240-1 (prisoners of war in Greek hands). 
--Empire in Central Asia: 336 n; 'Entente Libérale' Party: 181, 185; Government at Constantinople: see Porte, Sublime: Great National Assembly at Angora: $54,97 \mathrm{n}, 178,190,238,333$; Intervention in the European War: 141, 213; Musicians: 161; Nationalist Government at Angora: 23, 39, 54, 56, 84, 93, 100-1, 104-5, Chapter V. passim, 214, 223, 245, 277, 289-90, 311; Nationalist Movement: 18, 30, 57, 84, 92, 153-4, 179-96, 214, 229, 312, 322, 358; National Pact: 84, 188-190, 207-10, 349; War-material: 153, 186, 227; Women: 180, 344.

Turks:--Christian: 192-6; Gagauz: 194 n; Ghuzz: 194 n; Karait Jewish: 194 n; Saljuq: 111-15, 119, 129, 150, 193, 194 n; Türkmens: 342; Vardariots: 194 n; Volga; 355-6; Young: 129, 135-6, 269 n; see also Union and Progress, Committee of.

Ukranians: 110, 112.

Ulashly Iskelesi: 287 n, 288.

Ulster Auxiliaries: 262.

Ulstermen: 26.

Unemployment in Great Britain (1921): 3.

Union and Progress, Committee of: 129, 135, 151, 178, 186, 280.

United States of America: 28 (Greek colonies in), 60 (Senate of, and Non-cooperation Movement in), 66 (Spoils system in), 82 (Intervention of, in European War), 87, 125, 134 (attitude of, towards Far-Eastern immigrants), 162 (citizens of, traveling in Anatolia), 177, 180, 203-4, 249, 
257, 261-2 (lynching of Negroes in), 289 (citizens of, eye-witnesses of Turkish atrocities), 327 n, and 338 n (Southern States of), 335 (classical studies in), 359 (Non-co-operation Movement in).

Ushaq: 157 n, 176 n, 215-16, 229-30, 233, 236, 290.

Uvez Punar (Kaza of Yalova): 311.

Vacua, International: 40-4.

Varna: 34, 168.

Vases, Ancient Greek: 204.

Vasilikós, Mr. G. P.: $166 \mathrm{n}$.

Vendée, La: 262.

Venetia: 130 ,

Venetian Villa: 37.

Venice: 8, 37-8.

Venizelos (=Venizélos), Mr. Elefthérios: 39, Chapter III. passim, 141, 163-4, 1801, 183, 228-9, 232, 243, 271, 313.

Vespasian, Emperor: 150.

Vienna: 28-9, 204.

Vistritza (=Haliakmon), River: 242.

Vurla: 141.

Wahhabis: 30 .

Wakf: 172. 
Wallachia: 96.

Wars:--Balkan (1912-13): 17, 69-70, 129, 137-40, 145, 160, 231 n, 235, 239, 243, 276, 332, 352; Candia, of (1644-69): 37; Crimean (1854-6): 153; European (1914-18): 2, 36, 47, 58, 62 Chapter III. passim, 107, 112, $1181,141-5,148,151,156,159,175,185,188,190$ n, 202, 211 n, 213, $225,234,236,239,241,244,246,262,294,320,342,358$; FrancoPrussian (1870-1): 262; Franco-Russian (1812): 230; Franco-Turkish in Cilicia (1920-1): 84, 90, 104, 154, 191, 228, 242, 312; GraceoTurkish=Greek War of Independence (1821-9): 15, 17, 18, 64, 66, 122, 131, 167, 190, 243, 279, 337, 348-9, 352; Graeco-Turkish (1919-1922): $27,34-6,39-40,91-2,97-8,100-1,103,107-8,128,155-6,159,162-3$, 192, Chapters VI. and VII. passim, 350, 354, 357; Greek Civili (1823-4): 64 n, 349; Peloponnesian (431-404 B.C.): 221, 363-4; Russo-Turkish (1768-74): 355 n; Russo-Turkish (1828-9): 15, 18; Serbo-Turkish (180417): $17 \mathrm{n}$.

Washington, George: 180.

Western:--Churches: 28, 329; Civilisation, homelands of: 11; Hypocrisy: 353; Imperialism: Chapters II. and III. passim, 357; Intelligentsia: 342; Military attachés: 102-3, 254-8, 263, 294 n, 298, 299-311; Political ideas, Spread of: 4; Press: 28, 59, 91, 360; Public opinion and prejudice: $35,58-62,74$, 76, 89-91, 105, 137, 177 n, 190, 211-12, 327-53; Religious toleration: 8, 267-9; seamen: 188; soldiers: 2, 59, 84, 103, 344 . 
Westerners (=Franks): 9, 31, 108, 259 (conventional humanitarianism of modern), 344 (residing in the East), $359 \mathrm{n}$ (expelled from Japan and Abyssinia in the $17^{\text {th }}$ century).

Whitehall: 132.

Wilhelm II. of German, Emperor: 89.

William III. of England, King: $269 \mathrm{n}$.

Wilson, President Woodrow: 50, 60, 76, 178 n, 328.

Winterton, Earl: $79 \mathrm{n}$.

Wrangel, General: 83, 89, 225.

Xenophon: 216, $221 \mathrm{n}$.

Xerxes: 220.

Yalova, Kaza of: 259, 283, 293.

--Town of: 138, 263, 275, 282, 287, 294, 299-311, 315.

--Gemlik Peninsula: 153, 215, 242, 269, 277-8, 283-8, 292, 294, 297, 311, 313, $315-16$.

Yannina: 139, 164.

Ydhra: 124.

Yemen: 19-20.

Yenijé Vardar: 115.

Yorgo Kaptan of Gemlik: 286-7.

Yortan (Kaza of Yalova): 306, 309, 311. 
Yoryi of Arnautkeui, Yokátos: $282 \mathrm{n}$.

--Ormanjy (Greek Kuruju of Samanly): 294.

Yudenich, General: 50.

Yukara Bey Keui (near Bergama): 161, 170.

'Yunanistan' (=Kingdom of Greece): 130.

Yuruk Ali (Chetté leader in the Maeander Valley): 196.

Yuruks: 199-200.

Yusuf Kemal Bey: 54, 60, 84, 101, 178-9.

Zaghlul Pasha, S.: 181.

Zante: 338.

Zara: 126.

Zimmis: 268.

Zionism: 45.

Zoological Gardens (London): 41.

Zoroastrians: 224, 268.

(map illustration) 



\section{V}

\section{GREEK AND TURKISH GOVERNMENT ${ }^{1}$}

WHEN I visited Anatolia in 1921, war and politics and life and happiness there were dependent upon the rivalries of Western diplomacy, yet Western civilisation had less footing in the country than at any time since the Crimean War. At Smyrna and the places occupied by the Greek Army in the hinterland, the Allied Powers had voluntarily abdicated their control in favour of the incoming Greek authorities. Elsewhere, the control-officers had lost command of the situation as the Turkish National Movement gained it. When once the Greeks had landed, the possible consequences of breaking the armistice with the Allies did not weigh with the Turks against the certain consequences of failing to resist the invaders 
by force of arms. Rifles, breech-blocks, and munitions were no longer handed in; reservists were called up instead of being disbanded; and the Turkish regular army, which by May 1919 had been reduced by the control to less than 20,000 effectives, began to grow formidable again. For the controlling Powers it was an undignified position, and it was only made worse by the measures of coercion which they eventually took. In March 1920, there was a demonstrative naval and military occupation of Constantinople ${ }^{2}$; prominent Turkish Nationalists in the capital were arrested and deported to Malta; and next month the Ottoman Parliament, which had recently reassembled after a general election with an overwhelmingly Nationalist majority, broke up. The result was an open breach between the Nationalist Power in the interior and the Allies. Outlying detachments of British and Italian troops had hastily to be withdrawn to the coast (the French in Cilicia were already involved in military operations); some controlofficers, and an intelligence officer at Amasia, were allowed to leave; others, like Colonel Rawlinson at Erzerum, were imprisoned as hostages for the Malta deportees. The military consequences are described in the following chapter. The political result was that the Nationalist executive at Angora formally renounced its allegiance to the Porte and proclaimed itself the legitimate depository of Ottoman sovereignty. It had already made itself the de facto government of all Anatolia outside the Greek lines, but with this declaration and the withdrawal of the armistice-control, the elimination of Western authority from

\footnotetext{
${ }^{1}$ For the official apologia of the Greek Administration, see additional note to this chapter at the end of the book, p. 387.
} 
Anatolia was completed. That was the price paid by Western statesmanship for a precarious and unprofitable military domination over Constantinople. The English and French merchants there got little satisfaction out of the circumscribed omnipotence of their countries' Generals and High Commissioners, for their own business was boycotted by the productive interior. The railways once laid out by Western capital to serve Western trade were requisitioned by Greek and Turkish commanders, wrecked by raiding-parties, cut in half by the front. Even the American educational institutions, which had secured a privileged position by their scrupulous non-interference in politics, found it difficult to carry on. In the spring of 1921, the American staff of Anatolia College, Marsovan, were banished from the Nationalist territory because some of their Greek colleagues were suspected of complicity in the revolutionary 'Pontus' movement against the authority of Angora. From the moment of the Greek landing in May 1919, Western civilisation fell into the same adversity in Anatolia as in Russia after the Bolshevik Revolution. Not only its military and political control, but its trade, its capital investments, its cultural undertakings were inexorably rooted up. The war of extermination between the local nationalities, let loose by its own diplomacy, was an atmosphere in which it could not live. It was being frozen out and abandoning the field of the native flora of Greek and Turkish rule, which, given a few years of untrammelled growth and struggle for existence with one another, might leave as little trace of the West in Anatolia as there is to be found in Afghanistan.

\footnotetext{
${ }^{2}$ Under the armistice, the Straits had already come under Allied occupation, but the city of
} 
These two experiments in administration by Near and Middle Easteners, unfettered by customary restraints, are the subject of this chapter. It is difficult to separate them from the accompanying military operations and consequent war of extermination. The Angora Government was set up in order to mobilise the country's resources for a military effort, and the Greek High Commissioner at Smyrna assumed a war-dictatorship pending the inauguration of the constitution provided for the Smyrna Zone under the abortive Treaty of Sèvres ${ }^{1}$-a constitution which was still-born, because it could not come into operation until the treaty had been ratified. At the same time, there were some remarkable personalities among those engaged in the civil government on both sides of the front; and their respective merits as administrators may be judged by their comparative success or failure in stemming the fatal current that swept both parties towards excesses against each other.

On both sides there are indications that the leading men were wellintentioned, but in government, as in war, the Greeks were fighting a losing and the Turks a winning battle. Though he arrived too late to prevent the original Smyrna massacre ${ }^{2}$ the Greek High Commissioner started well. He immediately reduced the troops and the civilian Greek population to order and asserted his civil authority effectively in the occupied area. On the Turkish side, on the other hand, the civil authority of the Nationalist Government was weak to begin with, and remained so until the Turkish regular army was re-formed, for during the

\footnotetext{
Constantinople had been nominally exempt from it.

${ }_{1}^{1}$ Articles 65-83, particularly Article 72.

${ }^{2}$ See Chapter VII.
} 
interval the maintenance of the front had to be left to chettés, who in many cases were professional brigands and went on making their customary livelihood in the areas which they were 'defending.' Their depredations, being economic, took little account of nationality, and there are authentic cases of Turkish villages which, in this first phase of the struggle, actually called in the Greeks in order to be rescued from their national 'protectors.' 1 The Angora Government did not yet dare to interfere, for the object of its existence was to carry on the war, and it had nothing so far but this screen of chettés to oppose to the enemy. But there was an unmistakable change in the situation during the eight months that I spent in the area. By the winter of $1920-1$, the Turkish regular army was again in being $;^{2}$ the chettés were no longer indispensable; and the Angora Government promptly invited them either to join the ranks or to lay down their arms. Most of them did one or the other. One or two, like the Circassian brothers Edhem of Salyhly and Eshref of Sokia, preferred to desert to the Greeks. In either event their power came to an end, and they were replaced by regular Ottoman mutesarrifs and kaimakams of the ordinary type and standard. There were exceptions, like the chetté leader Osman Agha of Kiresün, who retained his all but nominal independence and got out of hand in 'Pontus' during the crisis of the final Greek offensive. $^{3}$ But over far the greater part of the country a civil administration was established which Western observers uniformly reported to be not less efficient,

\footnotetext{
${ }^{1}$ I came across several instances in the Kozak-a mountainous district, just north of Bergama, where the population is exclusively Turkish.

${ }^{2}$ See Chapter VI.
} 
and more honest, than the average Ottoman provincial administration before the European War. As Angora extended its rule, it was able to improve its standard. To begin with, it had often to raise revenue in its home territories by methods only distinguishable from those of the chettés by being called requisitions, and this had resulted in several serious revolts among the Turkish population. But in 1921 , as the regular sources of revenue came into its hands, it became able to pay its way. ${ }^{1}$ Its finances were assisted by the fact that there were no imports except free donations of arms, and by the end of 1921 it claimed to be balancing a war-budget without raising loans or printing fresh paper.

On the Greek side the opposite tendency was observable. From taking Circassian chettés into their service it was only a step for the Greek military authorities to raise Christian chetté bands. By April 1921 these were in full operation, ${ }^{2}$ and the High Commissioner at Smyrna could not or would not put them down. Even in the city of Smyrna, I found a distinct change for the worse between my departure in March and my return in August. In the winter, the Greek gendarmerie had been accused of occasional crimes against Moslems in the interior. In August, Moslems were being murdered by Greek soldiers in the city and its suburbs. ${ }^{3}$ Before, my Turkish acquaintances had visited me freely in

\footnotetext{
${ }^{3}$ See Chapter VII.

${ }^{1}$ I was told by a Karamanly Christian surgeon serving in the Nationalist Army, who had been taken prisoner by the Greeks in the battle of In Önü, and whom I visited on the $12^{\text {th }}$ April 1921 in the Brusa military hospital.

${ }^{2}$ See Chapter VII.

${ }^{3}$ I subjoin three instances, from a source in which I have complete confidence but which for obvious reasons I cannot yet specify:

(i) $29^{\text {th }}$ May 1921, at Iki Cheshmé, Smyrna City: Musa bin Ahmed Hajji Huseináki was killed on the way from a café to his house, and the corpse plundered. The murderers must have
} 
my hotel. This time they hesitated to be seen with me in the street, and for fear of compromising them I did not call on them in their houses. ${ }^{1}$ The Western business community, too, though they had complained of the paralysis of trade, had borne witness at the earlier date to the unprecedented security of life and property which the Greek police had established in the city and its suburbs, and had admitted that the falling-off of normal trade with the interior was partly balanced by contracts for the Greek Army. By the summer, the Greek QuarterMaster-General's office was in serious financial straits and its creditors were gloomy. ${ }^{2}$ Even apart from the atrocities which began in April (not only in the few places where there were Western witnesses, but all over the occupied territories), Greek rule in Western Anatolia was then distinctly on the downward path.

been Greek soldiers, for a Greek sergeant's epaulette (evidently torn off in a struggle) was found clutched in the corpse's hand;

(ii) $4^{\text {th }}$ August 1921, at Kiatyb oghlu, Smyrna City: Mehmed Agha was murdered by a Greek soldier, who entered his stable (on the ground-floor of the house) and shot him with his revolver as he came to the door in answer to the soldier's knocking;

(iii) $4^{\text {th }}$ (?) August 1921, at Cordelió (suburb of Smyrna): Emin, brother of Hasan Efendi, Directeur et locataire du Club des Turcs, refused to serve Greek soldiers with alcoholic liquor and in revenge was bayonetted in the neck that evening in the street.

I also have in my possession records (which I can published if necessary) of the murder of eight Turks in all at (a) Burnabad, (b) a country house near Kilisman, (c) Kömürderé, (d) Kyrkagach, and (e) Ushaq during April, May, and June 1921. Of these, five were killed by Greek gendarmes, two by Greek soldiers, and one by persons unknown. Besides these, I have records of numerous cases of beating, violation and forcible detention of women, and other crimes of violence stopping short of murder, which were committed by Greek gendarmes and soldiers, generally in conjunction with robbery.

'One Turkish gentleman of my acquaintance, who was a 'foreign-protected person,' used to hide every Sunday when the Consulate of the protecting Power was closed, because another person protected by the same Power had been kidnapped by Greek gendarmes one Sunday in broad daylight, and the Consulate had failed to obtain satisfaction from the Greek authorities.

${ }^{2}$ See speech by Lord St. Davids, delivered at the half-yearly shareholders' meeting of the Ottoman (Aidin) Railway Company on the $31^{\text {st }}$ March, and reported in the Times of the $1^{\text {st }}$ April 1922. 
It is no wonder that the Greeks failed, for, in sending them to Smyrna, the Supreme Council had set them the most difficult administrative task conceivable - that of governing a country with a mixed population in which one of the elements was of the same nationality as themselves. The parallel situation in Ireland was too much for the British nation, which has more experience than most in the arts of government, and the problem of ruling Turks and non-Turks in the Ottoman Empire had completely beaten the Osmanlis. On the other hand, the great strength of Greece, and of the other independent states founded by Near Eastern peoples formerly subject to Turkey, was the comparative homogeneity of population in the earliest liberated territories, which made the introduction of democratic national institutions on the Western model a not impossible undertaking. In accepting their mandate for the Smyrna Zone, the Greeks saddled themselves not with the White Man's but with the Osmanli's 'burden.' The establishment of the Turkish Nationalist Government in the rest of the country, which was an inevitable consequence, aggravated the problem, and the equally inevitable state of war between the two governments made it impossible to solve.

In comparing their respective achievements, it is only fair to point out that on the whole the Nationalists had the easier task. Though they too had to deal with a mixed population, the Turkish element in the country where they inaugurated their régime was in an overwhelming majority, and the non-Turks were not only hopelessly outnumbered but were accustomed (however painfully) to Ottoman sovereignty. In these territories the administration had been Ottoman 
for a minimum of four and in places for six centuries; ${ }^{1}$ it was not interrupted during the European War; ${ }^{2}$ and the Nationalists had merely to connect up the existing machinery with Angora instead of Constantinople and to overhaul it where it was out of gear. It was an old-fashioned instrument, but at any rate it worked. The Greek High Commissioner, on his side, took over an area in which the non-Greek element was almost certainly in a considerable majority, and where every usage and institution was against him. He stood for a revolutionary reversal of national relationships, which only time and tranquility could possibly have made acceptable to the party which was the loser by the change, and both these essential conditions were denied to him. Finally, while the Nationalists disposed of a broad hinterland only remotely affected by the War, the whole of the Greek Zone was sensitive to the disturbing influences of the front, and there was no physical barrier between the Turkish element in its population and the main body of the Turkish nation on the other side of the military lines.

The geographical difficulties of the Greeks' position round Smyrna are discussed from the military point of view in the next chapter. The administrative aspect can be illustrated from the partially parallel conditions created in Macedonia by the award of the Berlin Conference in 1878 and perpetuated until the Balkan War. The parallel is only partial, because the conditions of Turkish rule in Macedonia during that period were more favourable in two respects than

\footnotetext{
${ }^{1}$ The original nucleus of the Ottoman Empire, between Eski Shehir and Brusa, was in the Nationalists' hands till July 1921, but passed under Greek occupation as a result of the summer campaign of that year (see Chapter VI.).
} 
those of Greek rule in Anatolia. In the first place, while the Greek High Commissioner at Smyrna had uninterrupted war on his frontiers, Turkey and the Balkan States adjoining her Macedonian provinces were at any rate nominally at peace from 1878 to 1912, except for the brief and successful campaign against Greece alone in 1897. In the second place, these Balkan neighbours of Turkey and their respective kinsmen in Macedonia were more hostile to one another than to her. In took them thirty-four years to agree upon even a temporary military co-operation, and during the interval Turkey was able to 'divide and rule'-a policy for which Nationalist Anatolia, with its solid Turkish majority united under a single national government, gave the Greek High Commissioner little opportunity. ${ }^{1}$ In Macedonia, the Ottoman Government was also the customary sovereign of the country. Yet peace, custom, and the division among her enemies did not enable Turkey to administer successfully these outlying provinces inhabited by an alien majority and only marked off by artificial frontiers from a ring of hostile territory. The last phase of Ottoman rule in Macedonia was a byword, and the prospects of Greek rule in the Smyrna Zone were even more gloomy from the beginning.

Along the southern border of the Greek occupied territory, for instance, the conditions were least unfavourable when I visited it in February 1921, since there were no regular military operations in progress on this part of the front. It was too remote from the principal theatre of war, and detachments of Italian troops were

\footnotetext{
${ }^{2}$ Except for the temporary Russian occupation of the extreme north-east.

${ }^{1}$ For the Greek attempt to play off the Anatolian Circassians against the Turks, see p. 156 agove, and Chapter VII. below.
} 
holding the ring. Yet the Italians could not or would not prevent Turkish raiders from crossing the border, as Greek, Bulgar, and Serb 'komitajys' used to cross from the Balkan States into Macedonia, and there was a zone at least twenty miles deep in which the Greek authorities could not establish security. I had to have an escort of two gendarmes to explore the walls of Ancient Ephesus, only a mile or two from the railway-station of Ayasoluk; ten soldiers and five gendarmes to cross the mountains from Aidin to Tiré $;{ }^{1}$ and six troopers (on the alert at every village we passed) to ride over the Cayster plain from Tiré to the railway-junction of Torbaly. I was told by Greeks of daily encounters, with casualties, between Greek gendarmes and Turkish chettés, and by Turks of Turkish villages 'shot up' by the gendarmes for having given the chettés compulsory hospitality. It was the old story of Macedonia, word for word. Of course, there were exceptional districts. In the Bergama district, which was far from the border and where the High Commissioner was represented by an admirable lieutenant, ${ }^{2}$ I rode for two days through wooded mountains under the escort of a single gendarme, and at Yukara Bey Keui I found a detachment of half-a-dozen men in charge of ten scattered Turkish villages. The commander of this isolated detachment had just brought his wife out from Greece to join him, and the day I arrived being some festival of the Orthodox Church, they were being entertained by a party of Turkish musicians, with whom they were on the most friendly terms. No doubt

\footnotetext{
${ }^{1}$ See 'A Journey through the Mountains,' p. 196 below.
} 
such idylls could have been witnessed in Macedonia between 1878 and 1912, but in both cases they were no more than gleams of light in the gathering darkness of internecine war. ${ }^{1}$ My considered judgment is that it was as impossible for the Greeks to establish a good administration in Anatolia as it was for the Turks in Macedonia after 1878, and that if circumstances had allowed them to prolong their dominion there by force, it would soon have had the worst possible reaction upon their standards of government at home.

Before attempting to illustrate this view from my own observations, I must state that my final opinion of the Greek administration has proved considerably less favourable than my first impressions in the winter of 1921, partly because the Greek civil government seriously deteriorated afterwards in consequence of the military crisis in the spring and the outbreak of atrocities, but also partly because it took me time to realise the seamy side of what I had seen on my first survey. Of necessity, I had travelled under official auspices and was shown things from the official standpoint. ${ }^{2}$ I should also add that I have not had firsthand experience of the Turkish Nationalist administration. At the time when I was at Constantinople, Turkish resentment against the British Government's policy was so intense that it was impossible for a British subject to get a visa for travelling in Nationalist territory, and most of my information about conditions in the interior is derived from American relief-workers, missionaries, business-men,

\footnotetext{
${ }^{2}$ Mr. loannie Alexákis, 'nomárkhis' of Bergama, an Ottoman subject from Kush Adasy (=Scala Nuova), where he had been a landowner and British vice-consul, like his father before him. His profession, before entering the High Commissioner's service, had been the law.

${ }^{1}$ See Chapter VII.
} 
and journalists who were travelling freely between Constantinople and Angora by several routes from different Black Sea ports, and who thus saw between them a considerable part of the country. This information, though good, is of course second-hand, and I do not wish to lay stress on four days which my wife and I passed, by chance, in an area under Nationalist authority, ${ }^{3}$ as the time was short and the conditions, though testing, were exceptional. Whether personal experience would have given me a more or a less favourable opinion of the Nationalist administration than I have actually formed, I cannot say, and I must offer my impressions, such as they are, with this reservation. But I can speak with more authority of the Nationalist programme and point of view, of which some account is given at the end of the chapter.

In 1921, the dominating personality on the Greek side in Anatolia was the High Commissioner, Mr. Sterghiádhis. He began his career as a successful barrister in Krete, and bears the marks of his country and profession. He is highly-strung—resourceful and courageous but capricious and hot-temperedand his method of administration was to strike unexpectedly and hard, as if he were pleading a weak case or fighting a desperate duel. This fencing style of government, with its lunges, feints, and dexterous avoidance of hostile thrusts, is un-Western and particularly un-English, but then Mr. Sterghiádhis did not command the means of an Indian lieutenant-governor. To begin with, he was perpetually in financial straits, for he had to pay his own way without assistance

\footnotetext{
${ }^{2}$ This comes out in the two narratives written at Smyrna on the $21^{\text {st }}$ February 1921 , and printed at the end of this chapter.
} 
from the Greek Government; the local revenues had dwindled with the commercial isolation of Smyrna from the hinterland; and the Capitulations (which remained provisionally in force) made it difficult to tap new sources. He had no judicial system and no civil service. He had to hold his own against the military, who became less amenable as the military situation grew more grave. He was not sure of backing from Athens, for he was a nominee of Mr. Venizelos, and the Royalist Ministers only asked him to remain because it was impossible to find a successor. He had to improvise everything, pending the inauguration of the Sèvres régime, and to act as if he believed in the prospects of Greek rule in Anatolia, when every month it was becoming more evident that the Supreme Council's irresponsible decision would have to be reversed. On the other hand, if the Treaty of Sèvres had eventually come into force, he would have found himself in a still more delicate position, for under Article 83 he might have been confronted after five years with a plebiscite on the definitive attribution to Greece of the Smyrna Zone. If the demand for a plebiscite had been presented, as prescribed, by a majority in the local parliament, and if the popular vote had then gone in favour of Greece, he would infallibly have been accused of having misused his powers during the previous five years in order to bring about the decision; while if the vote had gone the other way, his fellow-countrymen would have made him the scapegoat for their national disappointment. Such difficulties might paralyse a professional Western administrator, but Mr. Sterghiádhis, who had been urged for a long time without effect to enter public life by his friend and

\footnotetext{
${ }^{3}$ At Ismid and neighbouring places along the south coast of the Gulf, between the $27^{\text {th }}$ June and
} 
fellow-islander Mr. Venizelos, had only been attracted towards it by abnormal conditions. Finally, after failing to excite his ambition, Mr. Venizelos had appealed successfully to his love for tour de force, and had persuaded him to undertake the Governor-Generalship of Epirus after the fall of King Constantine, when the province was in a chaotic condition owing to its temporary occupation by the Italians. Sterghiádhis went to Yannina, gathered some able young men about him, and got his hand in so successfully that Mr. Venizelos appealed to him a second time, in May 1919, to save the situation for Greece in Anatolia, after the disgraceful episodes which had accompanied the landing of her troops. ${ }^{1}$ That was how Sterghiádhis came to Smyrna. He could hardly have had a worse start or performed a more brilliant acrobatic feat than to keep afloat as he did in such a sea of troubles.

An anecdote from his apprenticeship in Epirus is worth recording. He had disposed of all but the one most redoubtable of the provincial brigands, when this gentleman invited him by letter to a tête-à-tête conference-in the mountains. The Governor-General accepted the proposal by return, with the stipulation that neither party should bring armed followers within a stated distance of the rendezvous. Arriving along at the appointed hour, he found the chieftain waiting for him in the open, but also observed rifle-barrels trained on him from behind every rock. Sterghiádhis was not the man to miss his opportunity. Without hesitation, he took the verbal offensive and overwhelmed the trickster with such a torrent of invective that, between shame and astonishment, he lost his head and

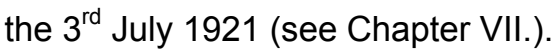


was immediately rushed by the Governor-General into satisfactory terms of capitulation, which he afterwards observed.

These qualities are invaluable in a dictator, especially when circumstances compel him occasionally to assume the brigand's role himself. People with a case against his administration at Smyrna certainly did not find Sterghiádhis easy to tackle. He was not loved either by Western consuls or by unofficial petitioners of any nationality, whom he had an unlimited capacity for ignoring, unless he chose to embarrass them by doing them more than justice, in order to choke off future applications. This was his favourite sleight-of-hand in holding the balance between the different elements in the local population. He gained some unpopularity among the Smyrna Greeks, but more credit among Western visitors and even among residents who ought to have known better, by occasional spectacular acts of partiality towards Turks, when Turks and Greeks were in conflict. He could not or would not prevent or redress the far more frequent injustices, great or small, which were done to Turks by the Greek military or gendarmerie or subordinate members of his own civil administration, or still more frequently by the Greek population with local official connivance; and he was quite clever enough to know that if general oppression of this kind went on, melodramatic personal interventions did not appreciably alleviate the hardships of the Turkish population and only embittered their feelings by masking the real situation. Probably, however, these gestures were the most effective that he could make in the circumstances.

\footnotetext{
${ }^{1}$ See Chapter VII.
} 
Every administrator is dependent on his instruments, and most contemporary administration in the Near and Middle East breaks down in its rank and file. Mr. Sterghiádhis had some worthy seconds, like my friend Professor Constantine Karatheodhorís ${ }^{1}$ of Göttingen, who in 1921 was organising a university for him and advising him on all manner of educational and social questions, or like the brilliant young agriculturist Mr. Frangópulos, of whom some account is given elsewhere. ${ }^{2}$ But what were they among so many? When he left Epirus, he insisted on bringing his nursery of young officials with $\mathrm{him}^{3}$ (a course which must have left his successor in difficulties), but in the larger zone of Smyrna they were not nearly numerous enough to go round. In the last resort the character of Greek rule in Anatolia depending not on the High Commissioner but on the ordinary captain or sergeant or even private of gendarmes, and these men were not fitted to rule over an alien population. Drafted out from Greece, they knew no Turkish and took no trouble to learn it, because they were

\footnotetext{
${ }^{1}$ Professor Karatheodhorís belongs to the well-known Greek 'Phanariot' family of the name, which has supplied the Ottoman Government with many distinguished public servants. The late Prince of Samos was a relative of his. His uncle was a government engineer in Mitylini under Abdu'l-Hamid, who devised an ingenious system of commuting taxes for labour locally employed on public works, so as to ensure to the taxpayer that his expenditure would be reproductive. By this method he enlisted the sympathies of the communes and got labour for equipping the island with excellent roads. Professor Karatheodhorís's father was Ottoman Minister at Brussels, and he himself was educated at the University of Liége. After a varied experience in Egypt and elsewhere, he was appointed to a Chair of Mathematics in the University of Göttingen, which he occupied with distinction for twenty years. He was interested in everything-archaeology, hygiene, economics, languages-and constantly reminded me of what I had read about Ludwig Ross and the other German savants who came out to Greece in the thirties of last century in the train of King Otto. In fact, Professor Karatheodhoris was a Westerner abroad-constructive, broad-minded, humane, and out of water.

${ }^{2}$ See 'An Agricultural Experiment,' p. 201 below.

${ }^{3}$ I was favourably impressed by the two whom I happened to meet: Mr. G. P. Vasilikós at Aidin and Mr. I. A. Naburis at Soma.
} 
uncertain how long they would be serving overseas. I came across Greek gendarmes who had been stationed for as long as nine months on end in purely Turkish rural districts without picking up more than a word or two of the language; and in one case, when I was being escorted, my companion knew so little that I had to do the talking when we wanted to ask the way. There was something more in this than laziness, for Greeks are good linguists and industrious in acquiring knowledge which may help them to get on. Their disinclination to learn Turkish was fortified by national hostility and disdain. Under-dog must speak topdog's language, and if he could not, so much the worse for him. He ought not to have made Greeks speak Turkish in the days of his own ascendency. So the unfortunate Turkish peasant with some vital petition to make, or under arrest on some serious charge, might have to hire the services of a Greek translator, who as likely as not would do his business badly; and when the Turk appeared in court he might be cross-examined by a hectoring interpreter on this Greek version of his case, of which he did not understand a word, until the presiding officer, bored by the dialogue, impatiently cut it short—having convinced himself once again that the Turks were a brutish and malignant people. Sterghiádhis might cherish the honourable ambition of being the Greek Cromer of Liautey, but national animosity stultified his efforts as inexorably as if he had been a wellmeaning Ottoman Vali of Salonika in 1912 or a liberal-minded English Viceroy of Ireland in 1921.

Undoubtedly his administrative operations reveal a deficit when one strikes the balance. On the credit side, the chief item was the repatriation of 
more than 120,000 Greek refugees and deportees, which was admirably done. In helping them, care was taken not to pauperise them or to weaken the tradition of local self-government (the great blunder made in building up the Greek Kingdom during the past century, after the War of Independence). As far as possible they were given loans rather than grants, and the total expenditure was well below the original estimate. Bergama and Aivali got on to their feet after the harvest of 1920; Kinik was struggling up by the winter of 1921; only the people of Dikeli had been disheartened by a plague of field-mice, which had cost them the fruits of a whole year's work. Relief was also given to the Turkish population. I saw destitute Moslem women receiving rations of food from the High Commissioner's representative at Aidin, ${ }^{1}$ and subsidies were paid to the Turkish orphanage (Daru'l-Yetim) at Smyrna. Besides this, certain positive measures were taken for economic and social development. In rural districts, cheap light ploughs were put on sale at cost price by the administration; an experimental farm for mechanical agriculture was established at Torbaly; ${ }^{2}$ and Professor Karatheodhorís began to organise his new university, of which the departments of hygiene (to combat malaria and syphilis, the two scourges of Anatolia) and oriental languages were to be launched in the autumn of 1921. If this scheme was prematurely ambitious, nothing could have been more practical then the

\footnotetext{
${ }^{1}$ On the other side it must be remembered that the devastation of Aidin was wholly due to the war let loose by the Greek landing (see Chapter VI. p. 226, and Chaper VII., pp. 273-4).

${ }^{2}$ See 'An Agricultural Experiment,' p. 201 below.
} 
overhauling of the municipal administration of Smyrna City, which was entrusted by the High Commissioner to a Greek refugee from Varna, Mr. Klionás.

Each of these items, however, is cancelled, or more than cancelled, by something in the debit column. The repatriation of Greeks, for example, was marred by the expropriation of their Turkish neighbours. Titles had of course been confused by the criminal violence of the Turks themselves between 1913 and the armistice, and it was natural that the Greek population should be tempted to retaliate when they returned as the dominant nationality. But the minor functionaries of Mr. Sterghiádhis's administration ought not to have been so incompetent or casual or partial as to grant false claims, and the High Commissioner himself ought to have seen to it that they did not do so. These inroads upon Turkish property continued after the repatriation of the Greeks had been completed. At Narly Deré and Balcha Ova, for instance, I was informed that certain Greek inhabitants had persuaded the Greek authorities in the summer of 1921, immediately before harvest, to give them possession of land owned and sown that year by Turks, on the ground that it was originally theirs. At Phokiés, not only expropriation but murder and violence were suffered, at the hands of the repatriated Greeks, by the Turkish element. In a place so near the centre of government, such excesses ought not to have occurred. The result was that from May 1919 onwards, even before systematic atrocities began, there was a vast emigration of Turks from the occupied territories. By the spring of 1921, the Ottoman Ministry of Refugees at Constantinople estimated the numbers at something between 200,000 and 325,000 , and there is no danger of 
exaggeration in at least equating them with those of the repatriated Greeks. ${ }^{1}$ No scientific agriculture or distribution of ploughs could make up for the diminution of productivity caused by such a drain on the population. The services of many Turkish peasants who remained were requisitioned for weeks and months at a time for military transport. They had to bring their mules and ox-carts with them, and many of these were destroyed, to the further impoverishment of the country. After the spring of 1921 , if not earlier, military service was also imposed on the local Ottoman Greeks. According to the report of an inter-Allied commission of inquiry, dated the $1^{\text {st }}$ June 1921 , 'The Greek Army have instituted conscription of those Ottoman subjects who are Christian refugees, who have to leave their families in great distress. ${ }^{2}$ In August I myself saw in prison at Smyrna a Greek Ottoman subject who had differed with the Greek military authorities as to whether he was of military age. ${ }^{1}$

The debit account also included military destruction, which may be none the less ruinous for being the result of 'legitimate warfare' (as distinguished from the 'atrocities' dealt with in Chapter VII.). Though there was no concentration of artillery, the Anatolian War did widespread damage owing to the constant shifting of the front. Even at the remote mountain village of Yukara Bey Keui, north of Bergama, I found nearly half the houses destroyed through having been shelled

\footnotetext{
${ }^{1}$ There are no exact statistics, because these refugees nearly all drifted eastwards into territories still held by the Nationalists, and did not pass through Constantinople or any other single distributing centre where count could be kept of their numbers.

${ }_{1}^{2}$ Parliamentary Paper, Turkey No. 1 (1921)=Cmd. 1478 (see Chapter VII.).

${ }^{1}$ See 'Greek Prisons at Smyrna,' p. 204 below.
} 
and set on fire at the time of the original Greek occupation, and hardly a village had escaped damage in really bad areas like the Maeander Valley. Still more deadly was the paralysis of trade-the stagnant port, the severed railways, the holding up of food-stuffs in the interior by the military authorities. In February 1921 , at Kula, one of the seats of the carpet industry, they were still executing orders for the Smyrna firms, but the wool which they were using came from the Angora district, on the other side of the front. They had certain stocks in hand, but what would become of their output when these were exhausted? Smyrna, again, is the headquarters of the largest liquorice firm in the world, because the best grade of root is collected in the Maeander Valley. This firm used to forward it from their up-country collecting-stations by the British Aidin Railway; but the chances of war placed the line in the hands of the Greeks and the principal rootbearing districts in those of the Turks, and severed the communications between them. Under such conditions, how could business be carried on? But I have sufficiently enlarged upon these economic losses already. I only refer to them again in order to insist that they must be reckoned into any estimate of the economic profit or loss which the Greek administration was bringing to the country.

It might, of course, be pleaded that the points examined so far throw more light on Mr. Sterghiádhis's predicament than on his personality. The anti-Turkish instincts of his subordinates and the economic ravages of the War were factors with which he had to contend but for which he was not responsible. There was, however, one 'acid test' of his statesmanship, and that was his personal policy 
towards the Turkish educated class and their institutions. To secure the goodwill of this class is the most difficult task for a foreign administrator in any subject country; yet without their co-operation good government is ultimately impossible (as British experience in Indian and Egypt shows), and to alienate them gratuitously is an unpardonable error. The heaviest indictment against Mr. Sterghiádhis is on this head. In some things, like the special attention paid to Kretan and Circassian in contrast to Turkish Moslem notables of the province, he was perhaps merely injudicious. ${ }^{1}$ But he inflicted a wanton wound in attacking the Sultaniyyah Secondary School, the École Polytechnique, and the Turkish Hospital in Smyrna City—institutions for which enlightened and patriotic Turks cared intensely, as precious instruments of national development.

Mr. Sterghiádhis, having appropriated the Sultaniyyah School building and converted it into law courts, attempted to defend his action ${ }^{1}$ by reference to the Treaty of Sèvres. When Articles 68 and 240 are read together, the local Greek

\footnotetext{
${ }^{1}$ During the Greek occupation some of the Kretan Moslem settlers, who had originally left their native island to escape from the Christians and are usually reputed to be more anti-Greek than the Turks, showed a surprising readiness to co-operate with the Greek authorities. Ali Bey, a Kretan landowner of Odemish, was the High Commissioner's liaison officer, or would-be liaison officer, with his Turkish administers, and Husni Bey, who had been Ottoman Mutesarrif of Manysa at the time of the Greek occupation, remained there as the High Commissioner's representative, being now surrounded entirely by Greek functionaries and gendarmes. This complacency on the Kretan Moslems' part towards their old Christian enemies seems due partly to community of language, partly to their bad relations, since their settlement in Anatolia, with their new Turkish neighbours. As regards the Circassian chetté-leaders Eshref and Edhem Beys, the empressement with which they were received in the winter of 1921, when they deserted from the Nationalists (see above), may have been due to the Greek military authorities rather than to Mr. Sterghiádhis. At any rate, the results were unfortunate, for, rightly or wrongly, educated Turks inferred that the Greek administration was trying to drive in a wedge between them and these non-Turkish Moslem minorities.
} 
administration appears to be entitled, if and when the treaty is ratified, to 'acquire without payment all property and possessions... registered in the name of the Turkish Empire or of the Civil List' and situated in the Smyrna Zone. Mr. Sterghiádhis claimed that the Sultaniyyah fell within this category, because the Imperial Treasury at Constantinople used to make it an annual grant of L.T. 40,000-a proof, in his estimation, that it was an Imperial and not a communal institution. The Turks replied to this, first, that the treaty had not come into force because it had never been ratified. They pointed out that on this account they had not yet enjoyed such benefits as the treaty secured to them-for example, the local parliament (Article 72) —and that it was therefore unjust to subject them by anticipation to provisions detrimental to their interests. But they laid more stress on the fact that, though there had been an annual government grant, the site of the Sultaniyyah was wakf land (that is, a religious endowment) and that the building had been erected twenty or thirty years before by public subscription. They therefore maintained—with evident justice—that Articles 68 and 240 were inapplicable.

The Greeks retorted that anyhow the Ottoman Government had ceased to pay the grant, that the Greek administration was quite unable to pay it, and that there were no educational grants on this scale in the Kingdom of Greece-the Sultaniyyah School having had nearly a hundred per cent. of free places. To this the leaders of the Turkish community answered that Mr. Sterghiádhis had never

\footnotetext{
${ }^{1}$ My presentation of the Greek case in this Sultaniyyah controversy is based on notes furnished to me by an official in the Greek High Commissioner's office. I have also discussed the subject with Mr. Sterghiádhis himself.
} 
given them a chance to raise funds themselves or to negotiate about the grant with the Ministry of Education at Constantinople.

The Greeks' next line of defence was that the Sultaniyyah was intended as a ladder of the Galata Serai Lycée or to the University at Constantinople, and that since the Smyrna district had been separated provisionally from Turkey, they saw no reason for maintaining special educational links with that country. If the Turks of the Smyrna Zone wanted higher education, they could go to the new Greek University at Smyrna or to Athens. The Turkish comment on this was that if the Sèvres Treaty involved the severance of such vital and well-established links as this, that merely showed once more how artificial and unjust it was.

The Greek authorities also pleaded that they were setting up a local Moslem Educational Commission, to exercise the powers enjoyed by the various Christian and Jewish Millets in the Ottoman Empire. I obtained confirmation of this from the Turkish side in August 1921, but with important qualifications. In the first place, it was not a new departure, for before the Greek occupation all provincial educational endowments had been allocated to provincial uses and were already administered by a commission of local notables (the Ministry of Education at Constantinople confining itself to supervision). In the second place, I was informed that the Greek High Commissioner had only offered to place funds allocated to primary education under Moslem administration.

This limitation, if it was a fact, struck me at once as significant, because it fitted in with an impression which I had formed, during my first visit in the preceding winter, regarding Greek policy. While the Greek rank and file were 
instinctively anti-Turk—an instinct which, unless kept in order, was bound to break out into excesses like those committed at the landing in May 1919 and again since April $1921^{1}$ — the higher civil authorities and certain enlightened Venizelist generals ${ }^{2}$ had evidently wanted to conciliate and gain the confidence of the Turkish peasantry - with the idea, I think, of detaching them from the Turkish governing class, whom they frankly regarded as irreconcilable to Greek rule. The war of extermination which began in April 1921 of course wrecked any chances that such a policy might have had, even if the first Smyrna massacre could have been got over; but the precedents in Egypt and India were in any case against its success, and I fancy that the Greek exponents of it were misled by having studied the first chapter of British administration in Oriental countries and ignored the second. It would be in accordance with this policy to encourage primary and at the same time to sabotage higher Turkish education, and the High Commissioner's proposal for reorganisation, if correctly reported to me, had very much this air. As far as primary education went, it was not ungenerous. The new Turkish Educational Commission was to administer, apparently, not only all provincial endowments for primary education but also the proceeds of the special virghi (tax) previously collected for educational purposes by the Ottoman Government-the Greek High Commissioner reserving the right to decide whether further funds were necessary. On the other hand, all the local

\footnotetext{
${ }^{1}$ See Chapter VII.

${ }^{2}$ The four whom I met in February at Alashehir, Ushaq, and Salyhly were replaced in their commands a few weeks afterwards by Royalists.
} 
endowments—both primary and secondary — hitherto administered by the Commission of Notables under the Ottoman Ministry of Education, had been taken over by the Greek authorities since the beginning of the occupation, and during the six months preceding August 1921 the income of neither branch had been paid over. Meanwhile, as has been explained, the Sultaniyyah endowment (both the site and the building) had been confiscated, as well as that of another important higher educational institution, the Turkish École Polytechnique, which had been maintained entirely out of private donations and had a governing body of local men. Even, therefore, if the reconstituted Turkish Educational Commission recovered control over primary education funds, the Turkish community had been robbed of its two principal endowments for secondary education, and had no assurance with regard to the remainder.

The High Commissioner's last line of defence in the Sultaniyyah controversy was to protest his readiness to pay the rent for a suitable alternative building, if the School could find one; but it was notorious that in Smyrna, as in most large cities after the European War, there was a dearth of housing accommodation-always excepting the two large unfinished buildings in which the new Greek University was being installed. Considering that one of these buildings had been started by Rahmy Bey, the previous governor of the province, with the intention of making it into a new Turkish University, ${ }^{1}$ the fair course would surely have been to house the new law courts there or else to assign the

\footnotetext{
${ }^{1}$ The other, I believe, was to have been a maternity hospital.
} 
building to the Sultaniyyah in exchange for its own. The Sultaniyyah was a going concern, fulfilling an ascertained need. Pupils were annually passing through it from the lower schools of the province to Constantinople. The new Greek University was a castle in the air, without local foundations-a doubtful experiment even if made at the cost of nothing else. These facts dispose of Mr. Sterghiádhis's otherwise not unreasonable plea that a judicial system was an administrative necessity, and law courts a public utility from which Turks as welwl as Greeks would benefit, so that he was merely transferring the Sultaniyyah building from one department of the public service to another. If the Sultaniyyah was not government property, and if Rahmy Bey's buildings were available, this contention falls to the ground.

The notes supplied to me by the Greek High Commission end, however, with a home thrust: 'At Constantinople the French, British, and Italians have occupied schools and wakf buildings' for their own military and administrative purposes. In truth, at Constantinople I found the French actually installed in one wing of the Galata Serai Lycée. 'Tant pis,' said the Turks: 'The Western Powers have set a bad example.'

A similar fate had overtaken the Turkish Hospital at Smyrna. This institution had an annual revenue from endowments of L.T. 7000 gold, was administered by a governing body of private individuals belonging to the province, and used to maintain in permanence 400 beds. The Greek High Commission took over the hospital and its revenue, cut down the number of beds first to eighty and then to forty, pocketing the whole amount of the savings on the 
revenue thus effected, and by August 1921 had entirely appropriated this hospital—a private endowment intended for the civilian public of the province-to the accommodation of wounded Greek soldiers. Accordingly, the Smyrna branch of the Ottoman Red Crescent Society (a private organisation dependent on local voluntary contributions) had opened a dispensary at Iki Cheshmelik, staffed by one physician, one surgeon, one midwife, and one dispenser, and attended by an average of 2500 out-patients a month. Of course this could not supply the place of the Hospital, but, in a time of poverty and under a foreign occupation, it testified to the initiative and public spirit of the Turkish community.

I have deliberately gone into detail in discussing the Greek High Commissioner's treatment of these Turkish institutions. It may not have been an exceptional piece of injustice. I should not be surprised to learn that equal or worse treatment had been meted out to dozens of German, Magyar, and Bulgar institutions in the vast territories newly acquired by Poland, Tchecho-Slovakia, Rumania, and Jugoslavia; and the same story may have to be told about Greek, Armenian, and American institutions in the territory held by the Turkish Nationalists. But it is generally recognised, in spite of the passions aroused by war, that these other defeated nationalists are fundamentally civilised and progressive, and it is regarded as a misfortune that members of them should have been brought under foreign rule by the accidents of geography or belligerency. On the other hand, the subjection of Turks to foreign rule, particularly in this controversial case of Smyrna, has frequently been defended on the ground that they are uncivilised and irreclaimable. This is not the case, 
but it is $\mathrm{t}$ rue that, for reasons touched upon in previous chapters, it is difficult for them to work out their modus vivendi with the West, and that they are backward in matters of private enterprise and organisation. Many of their own leaders are acutely aware of this, and have been struggling against odds to remedy it. The Sultaniyyah School, the École Polytechnique, and the Turkish Hospital at Smyrna were monuments of this endeavour, and it was heart-rending for those who had done such work to see it deliberately undone. While Greek propagandists in Europe and America, and their Western sympathisers, were representing Greek aspirations in Anatolia as the cause of civilisation, the Turkish population under Greek rule was actually being cut off by it from access to Western culture. The provisions of the Treaty of Sèvres in regard to Smyrna would stand condemned on this result alone, even if they had not also resulted in war and atrocities. 'The smoking flax he will not quench.' That text ought to inspire all Western dealings with non-Western peoples in our generation. Under the opposite treatment, how can the Turks or their fellow-Moslems in other countries be expected to persevere in the arduous enterprise of adjustment upon which the most enlightened among them have entered? This seemingly trivial injustice cuts through all the cant, prejudice, and misconception in which the 'Western Question' is habitually muffled, and goes straight to its heart.

Yet whatever colour Mr. Sterghiádhis's character may assume under the 'acid test' of his treatment of the Sultaniyyah School, the magic title 'Harmosts of 
Ionia' may be trusted to correct the visual impression. ${ }^{1}$ On the other hand, very few of my readers will credit the following description, drawn from life, of a 'People's Commissary of the Great National Assembly of Angora.' The individual of whom I am thinking was wearing (at least when I met him) a top-hat and morning coat which would not have betrayed him either inside—or for that matter outside-a London club, though he was less at home in England than in France. The attraction which had drawn him to London on previous occasions had been the reading-room of the British Museum. His study was comparative jurisprudence, about which he had interesting things to say and spoke with animation. In peace-time he was a university professor, but like other stormy petrels of that remarkable tribe, ${ }^{1}$ who love to venture out upon the sea of politics in revolutionary weather, he had temporarily abandoned his vocation for affairs of state. In fact, he was playing the part of a Minister of Foreign Affairs, and that was conspicuous ability. In a brief career he had already driven two very hard bargains-one with Mr. Chicherin at Moscow and another with M. FranklinBouillon at Angora. At the time when I met him, he was just going to try his hand on Lord Curzon, if not on Mr. Lloyd George. His name was Yusuf Kemal.

I infinitely regret that the policy of His Majesty's Government prevented me, as a British subject, from visiting Yusuf Kemal Bey's colleagues in the course of my travels in 1921, but as I was unable to make their acquaintance, I shall not

\footnotetext{
${ }^{1}$ Except in the eyes of that small minority of the Western public that is familiar with the history of Ancient Sparta.
} 
attempt an appreciation of them at second hand. In regard to Mustafa Kemal Pasha I have therefore only to say that he is not a Jew; not a member of that group of politicians who controlled the Committee of Union and Progress, and through it the Ottoman Empire, for half-a-dozen years between the coup d'état in January 1913 and the armistice of October 1918; and not under suspicion of making money or other personal gain out of his present position. He comes, I understand, from a Rumili Moslem family; he is a professional soldier; and at a time when smart officers in Turkey had as brilliant prospects in politics as smart lawyers in Greece, he distinguished himself, like Mr. Sterghiádhis, by sticking to his profession. At the Dardanelles he is reported once to have saved a critical situation by taking the command out of his German superior officer's hands. At any rate, he made sufficient mark to incur the jealousy of Enver, who used his powers as Minister of War to keep Mustafa Kemal in the background from that time onwards till his own downfall. The effect was the opposite to what Enver had intended, for when the triumvir fled the country, Mustafa Kemal emerged as a popular figure-a soldier with a fine record who had been persecuted by the men responsible for the national disaster. Just because he was known to be a personal opponent of Enver, the tame government kept by the Allied Powers at Constantinople let him loose in Anatolia (with the approval of the Allied military authorities) as an inspector-general of the Ottoman forces in the early summer of 1919, a few weeks after the landing of the Greek troops at Smyrna. Once there,

\footnotetext{
${ }^{1}$ Aristion of Athens, Steffens of Breslau, Massark of Prag, and Wilson of Princeton may serve as examples.
} 
he taught his countrymen a new answer to an old riddle. ${ }^{1}$ High Ottoman officials, at the instance of outraged Allied High Commissioners, recalled, degraded, and condemned the audacious rebel, but to no purpose. He proved by a personal demonstration that a Turk can be his own master in Anatolia without having to wait for a better world, and under his inspiration the National Movement sprang to life.

Other striking personalities gathered round him at Angora. Besides Yusuf Kemal Bey there was Dr. Adnan Bey, universally praised for his effective interest in the social welfare of the Anatolian peasantry, on which the future of the Turkish nation depends. A remarkable figure was Adnan Bey's wife, Halidé Hanum, the most celebrated pupil of the American College for Girls at Constantinople, ${ }^{1}$ who is one of the pioneers of the modern movement in Turkey for the emancipation of women, as well as a novelist, a political journalist, and an apostle of 'Pan-Turanianism.' But any selection of names must be arbitrary, for it is no exaggeration to say that, in some place and in some capacity, every Osmanli of character and energy became a worker for the national cause, and no individual names stand out like those of King Constantine, Mr. Venizelos, or Mr. Sterghiádhis on the Greek side.

\footnotetext{
${ }^{1}$ The riddle is: 'Where is a Turk his own master?' The traditional answer is: 'In Hell.' The inventor must have been some Chief Dragoman of a foreign embassy at Constantinople who had spent his life in applying the Capitulations in the capital of that 'sovereign independent state' the old Ottoman Empire.

${ }^{1}$ Now at Arnautkeu, on the Bosphorus, formerly at Soutari.
} 
Though Mustafa Kemal Pasha's name is far better known than Mr.

Sterghiádhis's, the Turkish administration in Anatolia did not derive its character from the dictator at Angora to the same extent as the Greek administration did from his counterpart at Smyrna. Nothing could be more dangerously misleading than the nickname 'Kemalists,' which both the Government and the Press in Great Britain were pleased to employ. It suggests that a military adventurer with a few confederates had somehow—by terrorism, cajolery, or magic — got hold of the interior of Anatolia and started a bogus 'movement,' which every selfrespecting Turk would have repudiated if the legitimate Government at Constantinople could have given the loyalists effective support. It implies an artificial, stagey, and scandalous pretension, of which respectable Governments could not take cognizance without loss of dignity, and which would certainly collapse sooner or later under the weight of the 'Principal Allied Powers' ‘ displeasure. This is, of course, the well-known ostrich-attitude which consecrated authority regularly adopts towards those who defy it. No doubt our ancestors once used to refer to the Americans as 'Washingtonists'; our Austrian contemporaries saw nothing but impertinent 'Massarykists' in the Tchechs; and we ourselves have recently been experimenting in this form of political 'suggestion' upon twelve million 'Zaghlulists' in Egypt. Of course, there are such things as spurious national movements, but every genuine national movement can also be explained away. All corporate action is started by individuals and carried on mainly by an active minority while the mass follows behind. But readers of the Jungle Book will remember that it was the stolid herd of buffaloes, 
and not Mowgli on the leader's back, that trampled the life out of Shere Khan. Opponents of political movements claiming to be national should take to heart Gamaliel's advice to the Sanhedrin: 'Refrain from these men and let them along, for if this counsel or this work be of men, it will come to naught; but if it be of God, ye cannot overthrow it-lest haply ye be found even to fight against God.' But it is hard for imperial peoples to avoid the paths of destruction. Their prophets prophesy falsely, and their people love to have it so.

Though I have not met Mustafa Kemal Pasha in the flesh, I can certify that he is not a 'Kemalist.' He is a Turkish Nationalist, and in 1921 I only met or heard of half-a-dozen Turks who were anything else. One was a merchant in a provincial town near Smyrna, who delivered in my presence the double-edged remark that he disliked the Nationalists as much as the Greeks. Another was Damad Ferid Pasha - the unfortunate son-in-law of the Sultan who twice let himself be lured into taking office at Constantinople during the period after the armistice, and burnt his fingers in trying to pull the Allies' (or rather, the British and Greek Prime Ministers') chestnuts out of the fire. A third (by hearsay only) was the Sultan. To these one must add the well-intentioned Prince Sabahu'd-Din and his friends (the would-be leaders of an 'Entente Libérale' Party), an uncertain number of Moslem ecclesiastics in the capital, and the encyclopaedic scholar Riza Tewfik Bey 'The Philosopher.'

It is amusing to note that the British Government's relations with the Sultan during the Allied occupation of Constantinople were attacked by the Turkish Nationalists and by the Indian Moslems with equal bitterness, but with 
diametrically opposite presumptions as to their character. Apparently the Indians considered that the Sultan was a prisoner under duress, and that the British Government were restraining him from exercising his lawful authority as Caliph of Islam. Undoubtedly the Turkish Nationalists regarded him as an opponent of constitutional government and almost as a traitor to his country, who was lending himself to British designs against their movement in the hope of recovering the autocratic power formerly enjoyed by Abdu'l-Hamid. In the Indians' eyes he was a tragic captive, in his own countrymen's a sordid tool. I do not think that this statement misrepresents the Nationalists' attitude, though they were naturally not so indiscreet as to publish it from the house tops. It was a symptom of the important and indisputable fact that the Angora movement was national and not religious in character. Its originators may not have been democrats (they certainly were not communists), and probably they contemplated a form of government in which an oligarchy of officials, officers, and other persons of Western education would be paramount over the hojas (ecclesiastics) and the peasantry. But however narrow the actual, if not the nominal, franchise might be, they were determined that the class enjoying it, and not the Dynasty, should be master in the country.

As Caliph, the Ottoman Sultan may be sacred to Indian Moslems, and his will (as far as it affects them) may be law, but in his own dominions he has always been subject, in the last resort, to the will of his servants. The Ottoman Dynasty has lasted because it has created a permanent professional public service; and this service (the efficiency of which has always affected the fortunes 
of the Empire at least as much as the character of the reigning sovereign) has constantly limited the Sultan's power. Even Suleiman the Magnificent had to humour the Janissaries by putting his name on their rolls as a private and ostentatiously drawing rations and pay. Later Sultans have lost their lives not only through palace intrigue but over controversial political questions like that of army reform (which was eventually carried through by Sultan Mahmud II.). Abdu'I-Hamid was not the first Ottoman autocrat whom his subjects deposed. Only Westerners ignorant of Ottoman history will make the mistake of treating the resistance of the Nationalists to the Sultan's authority as a bad joke and sneering at them as if they were truants from an infant school. This was really one of many chapters in the development of a genuine constitutional issue, and the precedents gave fair warning that foreign backers of the Sultan would once more lose their money. As for the formula that Great Britain was in duty bound to support the 'legitimate' Government of the Sultan at Constantinople, it was neither 'correct' nor sagacious. The schism in Turkish internal politics was the consequence of our occupation of Constantinople, and by favouring, on transparent diplomatic pretexts, the claimant to legitimacy who happened to be under our thumb, we were only strengthening his rivals. The history of France in 1792-5 and of Russia in 1917-20, and the triumph of King Constantine over Mr. Venizelos, ought to have taught diplomatists once for all that nothing is more surely fatal to either side in a domestic struggle than foreign support. If the Greek landing at Smyrna created the Turkish National Movement, the British support of the Sultan at Constantinople made its fortune. 
Damad Ferid Pasha, the only convinced opponent of the Nationalists whom local British policy succeeded in raising to the Grand Vizierate, exploited the Sultan's prestige in every possible way. In the winter of 1919-20, when the National Movement was still dependent upon chetté forces, he encouraged a Circassian chetté named Anzavur to start an anti-Nationalist movement in the Sanjak of Bigha (on the Asiatic side of the Dardanelles) and lavished titles and decorations upon him for a few local successes. ${ }^{1}$ There was even talk of organising a 'loyal' Turkish Army under British officers to reconquer the interior! But in April 1920, when the campaigning season came on, Anzavur's operations broke down, and a Greek offensive was needed to prevent the Nationalist Army from presenting itself at Chanak Kalé and Haidar Pasha. The Circassiansbroken reed though they had proved-were afterwards taken up by the Greeks, ${ }^{2}$ but Damad Ferid had another weapon which non-Moslems could not use--the appeal to religion.

There is some plausibility in the view that an Ottoman Caliphate and an Ottoman Constitution are incompatible ideals, and the hojas (ecclesiastics) as a class might be expected to support the Caliph in his claims to autocracy, on the ground that Nationalism threatened their influence as much as his. Undoubtedly a national consciousness and an organised religion are both exacting masters, and in contemporary Turkey it must be as difficult for hojas to steer their course as it is for Catholic bishops in Ireland. Can the professional representative of

\footnotetext{
${ }^{1}$ See Chapter VI. for the military aspect of Anzavur's activities.
} 
Islam afford to let the Western-trained officer and official and schoolmaster and physician capture the peasant's mind? On the other hand, can he venture to denounce a movement which has been so much more efficacious than all the ulema of Islam in defending Moslem territory against the infidel? Damad Ferid Pasha put these questions to the test by obtaining a fetwa from the Sheikhu'lIslam, in which the conduct of the Nationalists was condemned as contrary to religion. ${ }^{3}$ But in Turkey, too, there are such things as anachronisms, and the Grand Vizier's antiquated petard had the same effect as the artillery which Pius IX. used to bring into play against the leaders of the Italian Risorgimento. No one was injured by its explosion except the Grand Vizier himself. It made him so odious and ridiculous in the eyes of his fellow-country-men that he became an embarrassment to his patrons the Allied High Commissioners. When he offered his resignation, they did not press him to withdraw it, and thenceforth they found it advisable to tolerate at the Porte grand viziers of a more and more Nationalist complexion. Public opinion, when genuine, has a mysterious power. Constantinople was under effective military occupation, and the Turkish element does not amount to much more than fifty per cent. of the population, the remainder being more or less decidedly hostile to Turkish Nationalism. Yet, even here, Turkish feeling counted sufficiently to induce the Occupying Powers to

\footnotetext{
${ }^{2}$ See Chapter VII.

${ }^{3}$ The Sheikhu'I-Islam is the principal jurisconsult for Islamic law in the Ottoman Empire and the legal adviser of the Government. He is a member of the Ministry and falls with it, but as he is a legal officer as well as a politician, his opinions do not always accord with ministerial policy. A fetwa is a 'legal opinion,' whether given in response to a private or to an official question.
} 
defer to it. Tewfik Pasha, ${ }^{1}$ Izzet Pasha, and the other statesmen who took office in the capital during and after 1921, were in sympathy-even notoriously in sympathy—with Nationalist aims, but the High Commissioners shrank from the difficulties of trying to govern the occupied territory without them.

As for the 'Entente Libérale,' their claims to represent the Turkish nation were discredited by the very test which vindicated those of the Nationalist leaders. No inference, perhaps, could have been drawn from the fact that they were in exile during the European War, for while it lasted, entire nations were held down by force, and other exiles, like Professor Masaryk or Dr. Trumbié, afterwards returned to govern by popular consent. But all the King's horses and all the King's men could not set up Prince Sabahu'd-Din at Constantinople. Nor could the adhesion of Dr. Riza Tewfik Bey patch up the prestige of this decrepit political party. The 'Philosopher' had played a picturesque part in the 1908 Revolution, and had subsequently withdrawn from politics in disgust, like most of the best original members of the Committee of Union and Progress. But while many of the others offered their services to the new National Movement after the fall of Enver, Talaat, and Jemal, Riza Tewfik Bey turned his face in the opposite direction. In 1921 I found him honoured by his countrymen at all parties as a poet and a scholar, and I never once heard his independence of mind and disinterestedness of motive called in question. But I am certain that in his political views he was as exceptional as in his intellectual achievements. The

\footnotetext{
${ }^{1}$ Turkish Ambassador in London before the European War, not to be confused with the scholar
} 
only other name on my list of anti-Nationalist Turks known to me personally is that of a distinguished official whom I must here leave anonymous. As for those villagers who in the first phase of the Anatolian war took sides with the Greek troops against the Nationalist chettés, I have already explained that the conditions which had influenced them at the time were modified a few months afterwards. If I had had an opportunity of eliciting their views at the time of my visit in 1921, I should have found, I fancy, that they had changed their minds.

The rapid and spontaneous spread of the National Movement over the greater part of Anatolia may be illustrated by the following account of how the news of the Greek landing at Smyrna was received in the far interior. It was given to me in 1921 by an Englishman who in May 1919 had been Allied controlofficer in the town of X. Up to the end of May, he had been conducting the local process of disarmament without difficulty, though he had no troops with him and indeed no assistants but a couple of orderlies and clerks. In pursuance of the armistice, the Allied High Command at Constantinople was sending him orders for the progressive handing over of breech-blocks, rifles, ammunition, and other military stores. He was transmitting the orders to the Ottoman civil and military authorities, and they were obeying them to his satisfaction. Then one day there was a commotion in the market-place, and he was informed that an agitating rumour was the cause of it. Greek troops had landed at Smyrna and begun to massacre the Moslem population. He denied the rumour by proclamation, and the disturbance died down. Three days later, there was another and more 
serious commotion. This time the local Greek and Armenian bishops had received confirmation of the news from their Patriarchates at Constantinople. The officer denied it again, declaring that the story was impossible because the armistice terms were well known and Greece could not act in defiance of the Allies. Next day he received an urgent message from the Turkish commandant, and, calling at his office, found him in a state of collapse, with an official telegram from the Ottoman War Office at Constantinople on his desk. The telegram reconfirmed the news, and added that the Greeks had landed under the auspices of the Allies. Then the British officer wired urgently to his own chiefs to learn the truth, and eight days later received for the first time from them the information which had already reached him through every other channel. But his orders were already ceasing to be obeyed. The Turkish authorities were re-arming and drilling their men, and when he was eventually recalled to Constantinople, he was lucky to escape detention.

The doctrines to which the Turkish nation thus rallied under the influence of the Greek invasion were first preached openly by Mustafa Kemal Pasha while he was travelling as inspector-general up and down Anatolia. They were formulated into a programme by two congresses of notables held during the summer of 1919 at Erzerum and Sivas. The new party won a sweeping success in the parliamentary elections held during the following autumn and early winter; ${ }^{1}$

\footnotetext{
${ }^{1}$ The Nationalists were accused of having secured their majority by intimidation, but even if this
} charge were proved, the effect of intimidation on their part must at least have been 
and a solid phalanx of Nationalist deputies took their seats under the noses of the Allied High Commissioners at Constantinople, while the military leaders were reorganising the Turkish Army well out of the reach of British battleships or Greek divisions. In the Turkish capital, on the $28^{\text {th }}$ January 1920 , these deputies set their names to the celebrated 'National Pact'-a briefer and more interesting document than the Treaty of Sèvres.

The text of this Solemn League and Covenant is printed at the end of the chapter. Its historical importance does not lie so much in the specific resolutions, which were framed to meet a temporary situation, as in the spirit which informed them. A Persian army once chained itself together in order to conquer or die upon the field, and in the eighteenth century Western seamen used to nail their colours to the mast. The similar device of binding oneself to a creed by oath appears to have been a Scottish invention, and undoubtedly the authors of the Turkish Covenant had Western precedents in mind. Their demands can all be brought under a single formula: 'Most-favoured-Western-nation treatment for the Turkish people.' If the right of self-determination has been established for Western nations, the Turkish nation will insist upon sharing it. If it has been exercised by plebiscite in disputed areas like Silesia or Masuria or Klagenfurt, then there must be plebiscites in the Kars-Ardahan-Batum district and in Western Thrace. If administrative and military servitudes have been attached to international waterways passing through national territories, as has in fact been done with the Scheldt, the Danube, and certain German rivers, then Turkey will 
accept a similar statute for the Black Sea Straits. But like every Western Power, she must remain complete mistress of her capital, and the interests of foreign commerce must accommodate themselves to the necessities of national defence. Again, if certain rights have been secured to minorities, by treaties arising out of the European War, in defeated Western countries like Germany, Austria and Hungary, or in newly created or aggrandised countries of a Western or Westernised complexioni like Poland, Tchecho-Slovakia, Jugoslavia, Rumania, and Greece, the Turkish people have no objection to granting the same. In fact, they would gladly be quit, in exchange, of the more extensive cultural autonomy which hitherto they have allowed on their own initiative to Christians and Jews. Only, before they go further, they would like to make sure that Moslem minorities in South-Eastern Europe are benefiting by the minority treaties already signed. Finally, as regards the Capitulations, they might feel differently if Powers like England and France tolerated similar restrictions upon their sovereignty, but, from what they know about our domestic institutions, they assume that we agree with their own view that 'entire independence and complete liberty of action are a sine qua non of national existence, if a country's national and economic independence is to be assured and it is to be endowed with an up-to-date well-ordered administration.' They do not forget that they have been defeated or expect not to suffer for it, for Germany and Austria, their former Western Allies, have not been treated leniently. Accordingly, they resign themselves to losing the provinces inhabited by Arab majorities within the area 
subject to Allied military occupation under the terms of the armistice signed on the $30^{\text {th }}$ October 1918-but on the understanding that this occupation will be temporary, and that the destiny of the Arabs will be decided on the Western principle of self-determination, the application of which they have already claimed for themselves. The document begins and ends on a note of challenge. We await your terms, gentlemen of the West, but meanwhile we are taking our precautions, in case your terms should turn out to be in contradiction to your principles. By your principles we stand. After all, you invented them!

This is the spirit which breathes through the laconic articles of the Turkish National Pact, and gives them a permanent interest. The Pact was something more than a statement of war-aims or a party programme. It was the first adequate expression of a sentiment which had been growing up in the minds of Western-educated Turks for three or four generations, which in a half-conscious way had inspired the reforms of Midhat Pasha and the Revolution of 1908, and which may dominate Turkey and influence the rest of the Middle East for many generations to come. It was as emphatic an adoption of the Western national idea as any manifesto of the Greek War of Independence, and it was at the same time an appeal to Western public opinion. You revile us, it pleaded in effect, for having failed to establish a modus vivendi with you, but such adjustments have to be reciprocal. As one among your own prophets has said: 'Do unto others as ye would that they should do unto you.'

The Allied occupation of Constantinople, the break-up of the Ottoman Parliament, and the formal establishment of a National Government at Angora- 
events which followed one another during the spring of 1920—have been mentioned at the beginning of the chapter. The Great National Assembly was the body in whose name the new government at Angora was carried on. Fugitive deputies from the dispersed Parliament were given seats in it, as well as newly elected representatives from the Anatolian constituencies, but, like other wartime chambers, it did not exercise the sovereign power, and the ministers of state constituted a body of executive magistrates with the fashionable title of commissioner, which in Soviet Russia, British Egypt, Palestine, and Mesopotamia, French Syria, and Greek Smyrna was borne at the time by the de facto rulers. ${ }^{1}$

Before the war of extermination spread from the Greek occupied territories to 'Pontus' in June $1921,{ }^{2}$ the Angora Government had, as far as my information goes, a fairly good record. In the north-eastern provinces of the territory under its rule, the Constantinople Ministry of Refugees claimed, by the early summer of 1921 , to have repatriated 461,062 out of 868,962 Moslem refugees who had been uprooted by the Russian invasion of $1916-18$, as well as 335,000 Greeks and Armenians-statements which I reproduce with the reservation that I have had no opportunity to verify them. On the other hand, an unknown number of Armenian women and children appropriated by Moslem households during the terrible atrocities of 1915 remained in captivity, and I have not heard of steps

\footnotetext{
${ }^{1}$ The difference in connotation between the sinister word 'Kommissar' and the untarnished respectability of 'Haut Commissaire' and 'High Commissioner,' is a philological curiosity of the post-war period.
} 
having been taken by the Angora Government to release them, as it behoved them to do if they were to dissociate themselves effectively in Western eyes from the régime of Talaat and Enver. There were also something like 300,000 Armenian refugees from the same atrocities in the territory of the Erivan Republic, who had been living there for five years in extreme destitution and with an appalling death-rate, but who were not enabled to return to their homes in Ottoman territory, even after the formal conclusion of peace between Angora and Erivan at the close of 1920 . These were bad marks against the Nationalist Government, even allowing for the fact that they were omissions to repair the illdoing of their predecessors and not positive misdeeds of their own. As regards atrocities, those incidental to the Cilician campaign fall outside the scope of this book, ${ }^{1}$ while those committed against Greek minorities are discussed in Chapter VII. But, as under the neighbouring Greek administration, there were things that, without being technically 'atrocious,' were deplorable. During the winter of 19201 a number of unfortunate Greek railwaymen, belonging to the section of the Aidin Railway that was in the Nationalists' hands, were interned with their families under cruel conditions on an island in Lake Egirdir; and the accounts of the proceedings of the military tribunals in 'Pontus' which reached the Times correspondent at Constantinople, justify, if correct, his severe comments upon them. ${ }^{1}$ Short of atrocities, the standard of treatment meted out to minorities

\footnotetext{
${ }^{2}$ See Chapter VII.

${ }^{1}$ But see in this connection 'The Area of the Organised Atrocities,' at the end of Chapter VII. below.

${ }^{1}$ See the Times of the $18^{\text {th }}$ and $22^{\text {nd }}$ October 1921.
} 
seems, unfortunately, to have been set by the subordinate authorities on the Turkish as well as on the Greek side of the Anatolian front.

Perhaps the most curious episode of Nationalist administration in Anatolia was that of the 'Christian Turks.' From the summer of 1921 onwards, there were persistent reports, always emanating from Turkish Nationalist publicity agencies, of a new movement, headed by an Orthodox priest named Eftim (Efthymios) from Keskin in South-Central Anatolia, for founding a Turkish Orthodox Patriarchate independent of the Oecumenical Patriarchate at Constantinople. The Oecumenical Patriarchate appears to have considered the movement sufficiently substantial to require denunciation, and the Angora Government afterwards stated that, in view of this, they had refrained from giving encouragement to Papa Eftim and had not acted on his proposals until his movement had declared itself again, and this time unmistakably, after the Greek retreat from the Sakkaria. ${ }^{2}$ In fact, they claimed that it was a spontaneous manisfestation of Turkish national feeling among the Orthodox Christian minority, and stoutly denied that it owed anything to official pressure or inspiration.

This would, of course, have been a sensible and advantageous line for the Anatolian Orthodox minority to take. As has been explained already in Chapter IV., it is evident to any outside observer that their very existence depends on a good understanding with their Moslem neighbours, with whom they do possess the important link of a common vernacular language. But this hardly affects the

\footnotetext{
${ }^{2}$ See Chapter VI.
} 
credibility of the story, for in the Near and Middle East common-sense rarely governs action, and rulers are shameless in forging testimonials from their victims. For example, the Turkish villages round Aidin had suffered particularly from outrages by the Greek troops in the summer of 1919; many of them had been 'shot up' and burnt; but when I visited Aidin in February 1921, the Greek authorities showed me an 'original' document—duly written in Turkish and sealed by dozens of Turkish mukhtars (village headmen) from this very districtpetitioning for the perpetuation of Greek rule! 'Be it known until your worships,' ran the preamble, ${ }^{1}$ 'that your humble petitioners are not of the cursed tribe of the Osmanlis. The ancient and noble blood of the Saljuqs flows in their veins, and, like your worships, they have groaned under the tyranny of the Ottoman conqueror for centuries. Now that they have been liberated by Hellenic chivalry, the categorical imperatives of humanity and civilisation forbid their being abandoned to their tyrants again!'

The seals were the seals of the mukhtars, but the voice was the voice of an examinee in universal history, and there is the same suspicious erudition about the thesis attributed to Papa Eftim. According to this theory, the present Turkish-speaking Christian minorities in Anatolia are descended from Turkish immigrants earlier than the Saljuqs, or perhaps from Saljuqs converted to Christianity before the majority of the tribe was converted to Islam. They have always read the Bible and performed the Orthodox ritual in the Turkish language.

\footnotetext{
${ }^{1}$ I am quoting from memory only.
} 
Nothing connects them with the Greeks except their use of the Greek alphabet and their acknowledgment, hitherto, of the ecclesiastical supremacy of the Oecumenical Patriarch at Constantinople—both mere historical survivals from the cultural influence of the East Roman Empire.

This myth has no foundation. The Greek origin of these Turkish-speaking Christians in Anatolia is betrayed by the identity of the name 'Rum,' by which they are known in Turkish, with that of 'Romyí' (Romaîoi, or East Romans), which the Greek-speaking Christians of Constantinople and Athens still apply to themselves in their everyday vernacular. The transitional stage-half-way from Greek to Turkish—through which the language of the Cappadocian 'Rum' is passing at present, illustrates the process by which others, like the Karamanly, have become entirely Turkish-speaking. ${ }^{1}$ As for their ritual, it is not true (I believe) that they have ever previously performed it in Turkish. ${ }^{2}$ Like their Greekspeaking co-religionists, they have hitherto employed Ancient Greek for this, and the Turkish Bible in Greek characters was a Protestant gift from the American missionaries, at which Orthodox prelates at first looked askance. All this has

\footnotetext{
${ }^{1}$ There are, however, real 'Christian Turks,' of Turkish descent, in the Balkan Peninsula. The East Roman Emperors, like the Arab Caliphs, employed Turkish mercenaries from the Steppes in the ninth century after Christ, and these adopted the religion of their masters. A colony of them was settled by the Emperor Theophilus (A.D. 829-42) in the neighbourhood of Salonika, and these 'Vardariots' may be the ancestors of the little Turkish-speaking Orthodox communities that still exist to the east of Serres. Some of the Anatolian Orthodox also may be descended from such colonists, but there is no evidence for it. There are, besides, the Gagauz Orthodox Christians in Dobruja and Eastern Thrace-descendants, these, of Ghuzz nomads who invaded the Balkan Peninsula by the route north of the Caspian and Black Seas at the same time as the Saljuqs invaded the Anatolian Peninsula through Persia. But the Gagauz-like the Karait Turkish Jews and unlike the Anatolian Rum —not only speak Turkish but preserve their Turkish tribal name.

${ }^{2}$ See Addendum on p. 405.
} 
been narrated in Chapter IV., but the historical truth would not matter, if Papa Eftim really had the will to believe, or to make $\mathrm{h}$ is flock believe, the legend. In politics, what Plato calls 'Noble Lies' are often beneficial, and this one could be grafted on to the Tree of Knowledge so as almost to counterfeit nature.

Ecclesiastical autonomies and the translation of the Bible and liturgy into vernaculars are in the best tradition of Orthodox Christendom. The Orthodox Church, to its credit, never made Ancient Greek a sacred language or erected the Oecumenical Patriarchate into a Papacy, and it does not depend on external uniformity for the maintenance of a common communion and creed. There were four independently governed churches in the Orthodox communion from the beginning. There are now at least a dozen, an increase due almost entirely to peaceful secessions from the Patriarchate of Constantinople under the influence of the Western idea of nationality. In this fashion the local Orthodox Church became autonomous in Russia, and more recently in the Kingdom of Greece (1850-2), in Serbia (1879), and in Rumania (1885), and an autonomous Albanian Orthodox Church has recently been started by Bishop Fan Noli. Hitherto, the Oecumenical Patriarchate has never offered strenuous resistance of this tendency except in the case of Bulgaria, who had to struggle for her ecclesiastical independence in the ninth and tenth centuries, and again in 1870. But the almost complete triumph of political nationalism in the remnants of the Ottoman Empire between 1912 and 1920 portends the final extinction of an ecclesiastical institution which, however accommodating, is in the last resort incompatible with the national principle. The Greek-speaking Orthodox Christian 
inhabitants of the new provinces permanently acquired by Greece from the Ottoman Empire in Rumelia after 1912, are bound to be transferred, sooner or later, from the ecclesiastical jurisdiction of the Patriarchate at Constantinople to that of the Holy Synod at Athens, for the traditional relations of Church and State in the Near Eastern world require that the boundaries of ecclesiastical and political jurisdiction shall coincide. When this inevitable event occurs (and the party feud between Royalists and Venizelists has no doubt hastened its advent), the Oecumenical Patriarch will be left with no flock except the Greek-speaking Orthodox population of Constantinople and its immediate neighbourhood and the minorities in Anatolia. It is therefore to be expected that the Patriarchate will fight even harder to retain the Anatolians than the Bulgarians; and thus, whether Papa Eftim is the leader of a genuine movement (as Bishop Fan Noli certainly is) or an accomplice in an ingenious fake, his gesture has created a new situation. The issue rests with the Anatolian Orthodox minorities themselves, for considering their well-proved faculty for holding out against persecution, it is certain that the Patriarchate cannot coerce them into preserving nor the Angora Government into abandoning their old ecclesiastical affiliations against their own wishes. At this stage it is impossible to say whether common-sense and ties of neighborhood or sentimentality and contrariness will prevail with them. But pressure from either of the interested parties will only drive them into the arms of the other. Both the Patriarchate and the Angora Government will therefore be wise to maintain a passive and 'expectant' attitude, for each has great interests at stake-the Patriarchate, possibly, its existence, and the Nationalists the crowning of their 
endeavors, for a Turkish nation cannot live and flourish in Anatolia until the Christian minorities as well as the Moslem majority in the country have given it their voluntary allegiance.

\section{A JOURNEY THROUGH THE MOUNTAINS}

[Narrative written at Smyrna on the $21^{\text {st }}$ February 1921.]

We started from the konak at Aidin after lunch—myself, the sergeant, nine soldiers, and two horses. That morning I had climbed the acropolis at Tralleis-a steep, isolated hill on the plateau behind Aidin, where the ancient city stood-in order to get some notion of the road we should follow, but it had shown me little. The ravines, ploughed deep into the flanks of the hills by the abundant streams, wound away out of sight, and the nearest spurs hid the summits of the mountains. Southwards, in the opposite direction, the marvelous plain of the Maeander was in view, with the winding river, the bridge where the Greek and Italian outposts face each other, and beyond that the mountains of China and Mughla. However, that was not my direction. The village beyond the bridge, on the Italian side of the river, is the headquarters of a young man called Yuruk Ali, and the Italian Government does not guarantee your nose and ears if you trespass there. ${ }^{1}$

We followed the track up the stream that comes down from the mountains between the Turkish and Greek quarters of Aidin. For the first hour we passed

\footnotetext{
${ }^{1}$ When I wrote this, I was looking at the Italians and all their works through Greek spectacles.
} 
ruined and abandoned water-mills, then a ruined Turkish Village on the further side of the ravine. Then we began to climb a zig-zag path through ever thicker brushwood, and emerged after two hours on a spur of the mountains cleared of trees and occupied by the Turkish village where we were to pass the night.

Dagh Emir is a good village, as Turkish villages go. There is a Greek gendarmerie post there, and the headmen of the neighbouring villages came to call on us in the section commander's house. Afterwards we adjourned to the house of the headman of Dagh Emir, where the other men of the village were assembled. The section commander and the headman were on good terms. I could see that there was a familiarity between them which could not have been assumed for my edification. But how times have changed! The headman had done his first term of military service (thirty-six months) in Krete, when it was an Ottoman province. The section commander was a Kretan, and his father (he himself was young) must have been one of the rayahs whom the headman had to hold down. Now, the Kretan was master and the Turk the subject race, and if one race had to rule the other (which is a bad arrangement either way round), it seemed more natural that it should be so. ${ }^{2}$ The Kretan was a smart soldier-well shaven and clothed, intelligent and educated. The Turk was a primitive being. I do not know into what distant exile his subsequent terms of service may have carried him. Perhaps to the Adriatic of the Red Sea. But you would never have guess that he had been out of his native village, and those who had been 
fortunate enough to avoid military service had, in fact, never travelled more than a day's journey beyond their homes.

Next day we took a guide from Dagh Emir, and when we halted to eat I offered him a sardine. He told me then that it was the first fish he had eaten in his life (he was getting on for sixty), yet from Dagh Emir you look right down the plain to the Maeander mouth and see the glint of the sea. I asked him how far he had been. To Aidin and Tiré (the two market towns on either side of the mountains), and once in his life to Smyrna (a short day's journey from either town by train). This is the life of the Turkish peasant in the mountains, even in so comparatively civilised a district of Anatolia as the Smyrna Zone.

In the headman's house every man put his tobacco in the middle for common use (a gracious custom), and chestnuts and water were handed rounds. What should we talk about? In a Greek village we should have talked politics, especially when a conference had been convened for our special benefit in London. ${ }^{1}$ But my sergeant-the scoutmaster of Aidin and interpreter for Turkish and English in the Colonel's office—-knew better. He began to tell a story from the Qur'an: 'Once upon a time. ...' 'Yes?' murmured the Turks with a childlike expectancy, and listened open-mouthed. Seeing that the tale had a moral, I thought of Tolstoy's short stories, and as my Turkish does not run to narrative, I got the sergeant to translate. I began with the two pilgrims to Jerusalem. They were easily transformed into Hijjis going to the Haramein. 'The English

\footnotetext{
${ }^{2}$ In the light of subsequent experience, I withdraw this judgment and emphasise the words in brackets.
} 
gentleman says that once upon a time there were two Hajjis. ...' The mouths opened wider still. They had not expected to learn about Hajjis from a Frank, and the story went down well. I followed on with the peasant who bought land from the Bashkirs, and the company laughed when the sun went down and he fell dead half-way up the hill. But the sergeant knew best after all. 'Once upon a time,' he began again, 'a man was sitting under an oak tree and looking at a melon patch. He said: "God was mistaken in making the small fruit grow on the big tree and the big fruit on the small." Just then an acorn fell and hit him on the nose. "Thank God it was not a melon," he said. "God knows best after all."' This was the success of the evening, and I realised that if you talk to Turkish peasants you must be simple indeed.

The party broke up in good humour, and the sergeant and I stayed to sleep on the headman's floor. But the sergeant was taking no risks, and a sentry with fixed bayonet stood on guard all night at the headman's door.

Next morning we started early, for we had many hours-we could never discover quite how many - to go. At first it was six, it had risen to eight by midday, and it was ten before we actually arrived at Tiré. Towards the end of our journey we discovered that our old guide from Dagh Emir did not really know the road. He had determined to come with us for protection on the way, and had assumed a knowledge of the road in order to secure our company. The road wound downwards and upwards for hours through a tangle of valleys and hills-a narrow mule-track with thickets all round and the soil rooted up everywhere by

\footnotetext{
${ }^{1}$ I now realise that these Turkish villagers could not possibly have talked politics in our company,
} 
the wild boars. There are innumerable boars in this country just now. To Moslems they are unclean, and, before the Greek occupation, the Christians could not hunt them because they were disarmed. It is a magnificent countrynot unlike Greece, but ampler and more generously endowed. The mountains are made of softer stuff which disintegrates more readily than the Greek limestone, and the soil is clothed with trees and permeated with water. In every ravine water was flowing, though this has been an exceptionally dry year. Instead of goats (the scourge of Greece) there were cattle, small but fat and good yielders of milk. The tents of the Yuruks (Turkish nomads) were pitched here and there, and a little Yuruk girl with glossy brown hair made us a gift of salt when we stopped by the Sary Su stream for our midday meal. All over the mountains there were wild fig trees and olives, to within less than an hour's distance from the summit of the pass (though the altitude of the summit is nearly 3600 feet above sea-level), and the higher we climbed the more villages we saw and the more cultivation. The whole of this hill-country is fertile. Security, not soil or water, is wanting to make it productive.

Late in the afternoon our path led us through a village, and the men came out, hand on heart, to bid us welcome. Only one man, fat and swarthy, remained sitting on his sheepskin. We sat down beside him. 'I am feeling very ill,' he muttered. 'Where?' 'All over, head, arms, and legs, and I have had no appetite for six months.' It was a strange medical history for so stout and well-liking a man, and my sergeant remarked to me in Engish that he was a bad fellow. We 
continued our journey, and sure enough after half an hour our guide's tongue was loosed. 'That was a bad man,' he said, 'a chetté (brigand). Once at Dagh Emir, when we were all in the mosque, he came and took everything from our houses.' 'Why haven't you killed him?' I asked. 'He has still years to live,' was the answer. I took it to mean that he has associates who would avenge his death. Our sergeant offered to arrest the fat man, if our guide would give evidence against him. But no, he preferred to let well alone.

And so we marched along, always climbing higher and never seeing the summit, though now the sun was sinking fast. But at last the trees came to an end. We passed the springs from which the streams started, and suddenly we were on the edge of a precipice, looking straight down upon a plain as low and level as the plain of the Maeander from which we had been mounting steadily for a day and a half. It was the famous plain of the Cayster. Before us Tiré, our destination, was spread out like a city in an aeroplane photograph. Beyond, the sunset was tinging the snow on the mountains of Salyhly and Alashehir, which I had seen a week before from the further side. It was a wonderful moment, and God was kind. We were lighted by the moon down the rocky zig-zag track into the town, an hour and a half's journey more, and the weather did not break till we were safely in bed. Next morning, when I looked out of my window at Tiré, it was pouring with rain. The clouds were clinging to the sides of the mountains, and above them I could see the snow lying on the heights which we had crossed the evening before. 


\section{AN AGRICULTURAL EXPERIMENT}

[Narrative written at Smyrna on the $21^{\text {st }}$ February 1921.]

We arrived at Tepé Keui in the dusk. We had made the twenty-five miles from Tiré in not much more than four hours. The old chaussée, grass-grown and left unmetalled for years, was excellent for trotting. The road matched the country-derelict too. I think we passed through two (small) villages and one deserted tekké (dervish monastery). Yet the soil, I imagine, is one of the richest in the world. Far away, on the slopes of the mountains on either side of the Caystrian plain, we could see here and there some larger settlements, and I suppose there is cultivation in their neighbourhood. But in the middle of the plain, where our road took us, there is nothing. It is an empty land. The cause of this was indicated by the way in which we travelled: an advance guard of two soldiers riding 100 yards ahead; the captain from Tiré, my sergeant, and myself in the middle, and three soldiers bringing up the rear. We took special precautions when we passed through the villages, and the sergeant got worried if any horse lagged behind. We were still within the area infested by the chettés (brigands) who slip over from the Italian Zone. The captain pointed out to me a hill to the south. 'There was a scrap behind there yesterday. One killed on each side.'

At Tepé Keui my friends left me at the gate of the experimental farm and rode on to Torbaly — the junction of the Cayster and Maeander valley railways, with a considerable Greek population. I was greeted by the director of the farm and enjoyed his hospitality for the night and the following day. 
I had already heard the director's history. His father had been a shipowner in one of the Ionian Islands off the west coast of Greece, and had made money, like other people in that business. The son had been brought up in Europe (he told me that he had been in every European country except Norway) and had pursued a long course of study in scientific agriculture in Switzerland, and afterwards in Paris. Later, the family business had been transferred to Odessa, and my host, while young (he is a young man still), found himself very rich. He had a car of his own, and did what pleased him. Then came the War and Bolshevism. The father and brother were killed, the property disappeared, and he was left without a penny in the world. He bethought him of his studies in agriculture, and of the new method of performing agricultural operations by motor-tractors-a by-product of the 'tank,' which had just been invented. So he went into an engine works for eight months as an ordinary hand, acquired a thorough knowledge of the engines by which these tractors are driven, and was then employed by the Greek Government to cultivate a large estate in Thessaly for supplying the army with food. An old fellow-student from Paris joined him there, and they came on together a month or two ago to Tepé Keui, where they are no win the service of Mr. Sterghiádhis, the Greek High Commissioner for the Smyrna Zone.

Tepé Keui is Government property. The estate originally belonged to Abdu'l-Hamid. After the Revolution of 1908 it was transferred from the Crown to the State, and allowed to go to rack and ruin. My friend found the house dilapidated, the cattle-sheds choked with dung, the currant bushes suffocated 
with undergrowth and unpruned, the fig trees left to degenerate. He brought with him two old tractors which some Americans had scrapped as useless, but which he has managed to repair. He has with him twelve soldiers, seven pupils (all local Greek peasants), and a mechanic. He reckons that, with tractors, one man can perform all the agricultural operations for ten hectares in the year. At present he is only beginning, but the possibilities of expansion are almost infinite. We climbed to the roof of a building (the grand-stand of the Sultan's racecourse, now being transformed into a combined lecture-room and engine-shed) and surveyed his kingdom. The estate stretched away as far as the eye could see.

The villages on the horizon were in it, and the mountains beyond. The plain between us and the villages could grown currants and figs and olives, cereals and cotton. On the mountains there were innumerable wild figs and olives already, and he was offering possession of them to any peasant who would graft them and make them bear fruit.

In the director's mind (and in the mind of Mr. Sterghiádhis who appointed him) the real importance of Tepé Keui is educational. By this example, the peasantry-Turks and Greeks alike-are to learn to exploit the agricultural riches of the Smyrna Zone. But the experiment at Tepé Keui is of more than local significance. For all Anatolia it may mark the turn of the tide. For nine centuries now, the nomadism introduced by the Turkish conquerors from Central Asia has been divorcing Anatolia from agriculture, and now, perhaps, the plough 
(reinforced by the motor-tractor) is going to last to recover the ground it has lost. ${ }^{1}$ But the importance of this new mechanical farming may be greater still. We talked of the unnatural concentration of population, during the last century, in the great cities of Europe and America; of the countryside's revenge upon the city during the War; of the tension between town and country which has arisen all over the world, from Russia to the Middle West of America; and of the downfall of certain cities, like Vienna and, possibly, Smyrna. In my friend's opinion, we are on the even of a centrifugal movement of population, a demobilisation, as it were, of the overgrown towns. But in returning to the fields humanity will not forget what it has learnt in the factories. The great invention of the last centuryscientific machinery—will be retained and developed, and the earth will be cultivated as it has never been before.

This is what we talked about in Abdu'l-Hamid's villa, and I felt how strange a country Anatolia is. It combines the romance of the new and the old. Next day, as my train stopped at the stations on the railway to Smyra, I studied the headdress of the Turkish peasants on the platforms. It is the same kerchief or mitra, wound round the head and sometimes under the chin as well, that you see Asiatics wearing in the paintings on Ancient Greek vases. Darius wears just such a mitra in the famous battle-mosaic of Pompeii. These peasants are the Ancient Lydians and Phrygians, with nothing but their language changed. Yet the dominant impression is not the memory of Classical Antinquity. Old as its

\footnotetext{
${ }^{1}$ For a criticism of Mr. Frangópulos's view of nomadism and its influence in the Ottoman Empire,
} 
history is, you feel that the country has never been used by its inhabitants. The forests, the waters, the plains, still wait for the hand that will gather in their

riches. ${ }^{1}$ The romance is less of the past than of a new world in the making.

\section{GREEK PRISONS AT SMYRNA}

[Written at Athens on the $14^{\text {th }}$ August 1921.]

When I was at Smyrna the other day, I visited two prisons, one being the Central Prison near the konak (Government buildings) and the other an extemporized house of bondage in the Rue Maltaise. The former was decent as far as I penetrated—and that was only to the 'no-man's land between two parallel lines of bars, across which the prisoners were allowed to talk to their friends from outside. The second prison was not decent. It flanked both sides of one of those cul-de-sac passages which branch off at right angles from the narrow streets of Smyrna, and the principal cell on the ground floor had been a private warehouse under the Turkish régime. The bars which once protected the produce of the interior now penned in human beings. When I walked up to the bars and talked through them, there were about forty men inside, and I was told that at times the number rose to a hundred. Their misdemeanours varied from being suspected of a wish to join the Nationalist Army (if Turks) or not to join the Greek Army (if Greek Ottoman subjects), to being taken up drunk and disorderly in the streets, but they were all subjected to the same filthy and insanitary conditions. When I inquired about sanitary arrangements, the Greek warders burst out laughing and 
enlightened me by pointing to a corner of the room-undrained and on the same level as the rest of the floor, on which the prisoners slept without bedding.

Several of these unhappy people told me that they were ill, and certainly most of them had the appearance of being so. They told me further that the prison was never visited by a doctor, and that they were not provided with sufficient water to drink. I must do this much justice to the Greek warders, that they let me look and talk as much as I pleased, but then I do not think it occurred to them that there was anything to be ashamed of in the condition of the people and the building under their charge.

In the other and more decent prison, I visited two prominent Turkish inhabitants of Smyrna whose imprisonment since about two months previously had created some stir. With one of them (like myself, a professor and journalist) I managed to exchange a few words in the presence of the prison authorities. To the second-a provision merchant-I only succeeded in shouting across 'noman's-land' through the bars, but I afterwards made inquiries about his case from several sources, and give my results, with the necessary reservation that I had no time to verify them and that they represent only the prisoner's side of the case.

There seems no doubt that, rather less than two months ago, this gentleman had suddenly been thrown into prison (where he still remains without trial) on the ground that he had been selling sugar in Smyrna at a price several piastres per 'oka' below that of his fellow-merchants, who are of course mostly

\footnotetext{
${ }^{1}$ For the bearings of this, see p. 134 above.
} 
Greeks. He imported his sugar from Constantinople, not on his own account, but as commission-agent for an Armenian merchant in business there. Sugar so imported does not pay duty on arrival at Smyrna, because Smyrna is still juridically Ottoman territory, and the sugar is supposed to have paid the Ottoman customs-duty when it originally enters Ottoman territory at Constantinople. His accusers declared that the duty on this sugar had not in reality been paid at Constantinople; that, by making a false declaration to this effect, he had evaded paying duty altogether; and that this was how he had managed to undersell his competitors. The prisoner, on his side, maintained that duty had been paid at Constantinople; explained the lower price on the ground that the sugar sold consisted of old stocks originally bought below the current wholesale price; and pleaded that in any case he was not responsible, since he had not sold the sugar on his own account but merely as agent for a principal in Constantinople. He had memorialised the Greek High Commissioner, and in support of his contention had submitted, six weeks before my visit, twenty-four business letters, addressed to him by the merchant of Constantinople for whom he had been acting. But the Greek authorities had postponed the case pending inquiries in Constantinople, and these may take months, while the merchant remains in prison and his business goes to pieces. It appears that he has offered to find sureties up to LT. 12,500 , or to deposit that sum himself as bail in a bank, but the Greek authorities refuse to release him on bail unless the money is paid over to themselves. This is natural, but it is also natural that the merchant should refuse, in the belief that if once he paid the sum over to the authorities he would never recover it. So in 
prison he remains. Turkish circles in Smyrna believe that he is the victim of a plot by the Greek merchants to ruin his business. This may or may not be true, but certainly it is not incredible.

This is all that I was able to see of the Greek prisons in Smyrna during a short visit. Of course the question is one of comparison. How do these Greek prisons compare with those of the civilised countries with which Greece claims to rank, and with those of the Ottoman Empire over which she claims so great a superiority? The comparatively decent prison was originally built and equipped by the previous Ottoman authorities. The obscene prison is a new creation of the Greek régime. Perhaps the Greek authorities will claim indulgence for the conditions which I observed in the Maltesica prison on the ground that it is an emergency arrangement. But, then, how is it that the Greek administration in Smyrna needs more prison-accommodation than its predecessor?

\section{THE TURKISH NATIONAL PACT}

(L'EMPIRE OTTOMAN EST MORT! VIVE LA TURQUIE!

FRENCH TEXT, OBTAINED FROM A TURKISH SOURCE 'CHAMBRE DES DÉPUTÉS OTTOMANE.

'Les Députés du Parlement Ottoman ayant approuvé et signé le Pacte National, don't nous donnons ci-dessous la copie, déclarent les principes qui y sont énoncés comme renfermant en eux le maximum de sacrifices possibles 
auxquels la Nation Ottomane pourra consentir, en vue de s'assurer une paix juste et durable.

\begin{abstract}
ARTICLE I.
'Le sort de territories de l'Empire Ottoman exclusivement peoples par des majorités Arabes, et se trouvant, lors de la conclusion de l'armistice du 30 octobre [1918], sous l'occupation des armies ennemies, doit être réglé selon la volonté librement exprimée par les populations locales.

'Les parties de l'Empire situées en deça et au delà de la ligne d'armistice et habitués par une majorité musulmano-ottomane dont les elements constitutifs, unis par des liens religieux et culturels et mus par un même ideal, sont animés d'un respect réciproque pour leurs droits ethniques et leurs conditions sociales, forment un tout qui ne souffre, sous quelque prétexte que ce soit, aucune dissociation ni de fait ni de droit.
\end{abstract}

ARTICLE II.

'Quant au sort des trios Sandjaks de Kars, Erdehan et Batoum, dont la population avait dès sa libération affirmé, par un vote solennel, sa volonté de faire retour à la mere patrie, les membres signataires du present Pacte admettent qu'au besoin il soit procédé à un second plebiscite librement effectué.

ARTICLE III. 
'Le statut juridique de la Thrace Occidentale, dont le règlement avait été subordonné à la paix turque, doit se baser sur la volonté de sa population librement exprimée.

\begin{abstract}
ARTICLE IV.
'La sécurité de Constantinople, capitale de l'Empire et siege du Khalifat et du Gouvernement Ottoman, ainsi que celle de la mer de Marmara, doivent être à l'abri de toute atteinte.

'Ce principe une fois pose et admis, les soussignés sont prêts à souscrire à toute decision qui sera prise d'un commun accord par le Gouvernement Impérial, d'une part, et les puissances intéressées, de l'autre, en vue d'assurer l'ouverture des Détroits au commerce mondial et aux communications internationals.
\end{abstract}

\title{
ARTICLE V.
}

'Les droits des minorities seront confirmés par nous sur la même base que ceux établis au profit des minorities dans d'autres pays par les conventions ad hoc concludes entre les Puissances de l'Entente, leurs adversaires et certains de leurs associés.

'D'autre part, nous avons la ferme conviction que les minorities musulmanes des pays avoisinants jouiront des mêmes garanties en ce qui concerne leurs droits. 


\section{ARTICLE VI.}

'En vue d’assurer notre développement national et économique et dans le but de doter le pays d'une administration régulière plus moderne, les signataires du present Pacte considèrent la jouissance d'une indépendance entière et d'une liberté complète d'action comme condition sine quâ non de l'existence nationale.

'En consequence, nous nous opposons à toute restriction juridique ou financière de nature à entraver notre développement national.

'Les conditions de règlement des obligations qui nous seront imposes ne doivent pas être en contradiction avec ces principes.

'Constantinople, le 28 janvier 1920.'

\section{CLOSE TRANSLATION FROM THE TURKISH, MADE INDEPENDENTLY OF} THE FRENCH VERSION, OF THE TEXT OF THE NATIONAL PACT, AS PRINTED IN THE PROCEEDINGS OF THE TURKISH CHAMBER OF DEPUTIES OF THE $17^{\text {TH }}$ FEBRUARY 1920.

'The Members of the Ottoman Chamber of Deputies recognise and affirm that the independence of the State and the future of the Nation can be assured by complete respect for the following principles, which represent the maximum of sacrifice which can be undertaken in order to achieve a just and lasting peace, and that the continued existence of a stable Ottoman Sultanate and society is impossible outside of the said principles: 
First Article.- Inasmuch as it is necessary that the destinies of the portions of the Turkish Empire which are populated exclusively by an Arab majority, and which on the conclusion of the armistice of the $30^{\text {th }}$ October 1918 were in the occupation of enemy forces, should be determined in accordance with the votes which shall be freely given by the inhabitants, the whole of those parts whether within or outside the said armistice line which are inhabited by an Ottoman Moslem majority, united in religion, in race and in aim, imbued with sentiments of mutual respect for each other and of sacrifice, and wholly respectful of each other's racial and social rights and surrounding conditions, form a whole which does not admit of division for any reason in truth or in ordinance.

Second Article.-'We accept that, in the case of the three Sandjaks which united themselves by a general vote to the mother country when they first were free, recourse should again be had, if necessary to a free popular vote.

Third Article.- 'The determination of the juridical status of Western Thrace also, which has been made dependent on the Turkish peace, must be effected in accordance with the votes which shall be given by the inhabitants in complete freedom.

Fourth Article.-'The security of the city of Constantinople, which is the seat of the Caliphate of Islam, the capital of the Sultanate, and the headquarters of the Ottoman Government, and of the Sea of Marmora must be protected from every danger. Provided this principle is maintained, whatever decision may be 
arrived at jointly by us and all other Governments concerned, regarding the opening of the Bosphorus to the commerce and traffic of the world, is valid.

Fifth Article.- 'The rights of minorities as defined in the treaties concluded between the Entente Powers and their enemies and certain of their associates shall be confirmed and assured by us_-in reliance on the belief that the Moslem minorities in neighbouring countries also will have the benefit of the same rights.

Sixth Article.- - It is a fundamental condition of our life and continued existence that we, like every country, should enjoy complete independence and liberty in the matter of assuring the means of our development, in order that our national and economic development should be rendered possible and that it should be possible to conduct affairs in the form of a more up-to-date regular administration.

'For this reason we are opposed to restrictions inimical to our development in political, judicial, financial, and other matters.

'The conditions of settlement of our proved debts shall likewise not be contrary to these principles.

'January $28^{\text {th }}, 1920 . '$ 


\section{THE MILITLARY STALEMATE}

THE failure of the Greek campaign in Anatolia was an event of more than local and temporary importance. It marked a distinct turn in a tide which had been flowing for over 200 years. The Western public has grown so used to the breakup of the Ottoman Empire that it takes the process for granted and assumes that it will go on till there is no Turkish state left on the map, while some publicists have gone so far as to prophesy the extinction of the Turkish nation. But if this process be examined, it will be found to have passed through two different phases, and to have entered on a third in which it is tending towards equilibrium. During the first phase (1682-1814) Turkey lost territory almost exclusively to Austria and Russia, the nearest Western or Westernised Great Powers. From 1814 to 1913 , on the other hand, her losses to other Powers were inconsiderable, ${ }^{1}$ and her progressive break-up took the form of successful internal secessions—by subject nationalities in her Near Eastern and by ambitious viceroys in her Middle Eastern provinces. In the third phase, which began with her intervention on the losing side of the European War, it looked at first as if she might suffer total shipwreck. The appetites of the Powers were unleashed as they had never been before; Greek and Arab nationalism joined in

\footnotetext{
${ }^{1}$ To Russia, only (i) the fortresses of Akhaltsikh and Akhalkalaki and the three districts of KarsArdahan-Batum in Transcaucasia, and (ii) the islands of the Danube Delta; to Austria-Hungary, Bosnia-Herzegovina; to Italy, Tripoli and the Dodecanese; to Great Britain, Cyprus (neither Cyprus nor the Dodecanese being formally annexed till after the outbreak of the European War). France took Algiers and Tunis, and Great Britain Egypt, not from the Ottoman Empire directly, but
} 
the hunt; and Turkey at the armistice seemed to be at the mercy of overwhelming hostile forces. In reality, perhaps, her salvation was at hand. The loss of the Arab provinces in addition to Rumelia made it possible for her at last to concentrate her strength in her home-lands. The Western leaven of nationalism, which had weakened her for a century while it was working only among her Near Eastern subjects, was now at work in her own people, and was beginning to call out their latent energies. The Western peoples, more sober than their statesmen, were imposing vetos on their partition schemes. Turkey suddenly found herself face by no serious opponent except Greece, and that in a military arena where all the advantages were on Turkey's side. By September 1921, in the twenty-ninth month of the Anatolian campaign, it had become evident that there would be no military decision, and that the war would be ended either by the mediation of the diplomatic protagonists, that is, of the Entente Powers, or by the national exhaustion of one of the belligerents. It was further evident that, if it were to be settled by exhaustion, Greece would break down first. The diplomatic developments which caused the Anatolian question to be decided by singlecombat between Turkey and Greece, have been discussed in previous chapters. This chapter is concerned with the military factors contributing to the final result. The most important of these factors was the geography of the theatre of war. Neither belligerent had sufficient military resources to dominate the zone of operations, corner his adversary, and deliver the 'knock-out blow.' Even in the summer of 1921, when each had mobilised his maximum man-power and 
begged or borrowed all the munitions and equipment that he could get from abroad, Anatolia still looked like a chessboard on which there were too few pieces to finish the game. There they must stay till the players got up and left them, or superior beings swept them into a box and folded up the board. There could be no checkmate.

After the entry of the Ottoman Empire into the European War, its pre-war territories were invaded on three sides (leaving out of account the abortive Russian invasion of the north-eastern provinces) by foreign powers more or less resolved on permanent occupation. Mesopotamia was invaded by the British; Palestine and Syria by the British, the Hijazis, and the French in combination; and finally Western Anatolia by the Greeks. The second of these operations was perhaps the most difficult of the three. It had to be based on Egypt, with the Suez Canal and the desert across the invaders' communications, and in its second act-that is, the conquest of the Syrian interior by the French from the Hijazis ${ }^{1}$ - the aggressors had to operate from the sea and cross two parallel ranges of mountains, only traversed by a rack-and-pinion railway, in order to get from Beirut to Damascus. But if once you have successfully invaded Syria and Palestine, they are comparatively easy to hold, for the sea on one side and the Arabian desert on the other provide practicable military frontiers enclosing a territory of manageable size. In contract to this, Mesopotamia and Western Anatolia are not so difficult to occupy. From Basra a navigable river, ${ }^{2}$ and from

\footnotetext{
facto.

${ }^{1}$ In July 1920.

${ }^{2}$ Duplicated by military railways during the British invasion.
} 
Smyrna a railway-system radiating up open valleys, offer access to the interior. The problem is not so much to conquer these areas as to hold them when you have done so, for neither of them has any natural boundaries. The incautious invader of Mesopotamia must push on and on to the Taurus passes and the Persian plateau, ${ }^{3}$ if not to the Caspian and the Caucasus, before he finds frontiers which he can hold securely. He cannot be indifferent to the reoccupation of Transcaucasia by Russian garrisons or to Bolshevik raids in NorthWestern Persia, and the restoration of Ottoman sovereignty over a section of railway between the Taurus tunnel and Nisibin disturbs his peace of mind. Indeed, he is sensitive to military movements hundreds of miles away from the original territory which he set out to hold, and the invader of Western Anatolia is in much the same position. He, too, can find no comfortable frontier till he strikes the Taurus from the other side ${ }^{1}$ or reaches the north-eastern escarpment of the Anatolian plateau. Pan-Turanianism is a bogey to him, an entente between Angora and Moscow almost a cause for despair. Had the Tsardom remained in existence, the Greek occupation of Western Anatolia and the British occupation of Mesopotamia would have been less unmanageable problems. The forces opposing each of them would have had a powerful enemy in their rear, and might have been overawed or pinioned. This was the presupposition of the Secret Agreement of 1916. The frontiers between the projected British, French, and Russian Zones in the Middle East would have been as artificial as those which

\footnotetext{
${ }^{3}$ The frontiers which drained away the strength of the Ancient Assyria.
} 
formerly divided the Prussian, Austrian, and Russian holdings in Poland. But the three invaders might have strengthened the foundations of their rule by buttressing each other. On the other hand, with Russia on their side, Turkish and Arab and Persian nationalists, Pan-Islamists, Pan-Turanians, and all other Middle Eastern opponents of Western domination obtained a boundless manœuvring ground and a secure line of retreat. They could venture on resistance, and the longer they kept it up, the more the invaders would be embarrassed by the configuration of the country.

Western Anatolia has, it is true, a patch of desert in its hinterland, but this possible frontier lies at an average distance of more than 250 miles from the west coast (instead of the 100 miles which separate desert from coast in Syria). Moreoever, there are gaps at the end of this desert, leading on, round its northern and its southern border, into the vast interior of Central and Eastern Anatolia. The value of the Anatolian desert as a frontier for a conquerer of the western part of the country must therefore not be over-estimated.

Starting from the west coast at Smyrna or the neighbourhood and following the two main river valleys (the Hermus and Maeander, each provided with a railway) inland and eastwards, the invader first traverses a hundred miles or so of open river valley, with a landscape like that of Greece, except for the softened outlines and the greatly enlarged scale. Then he encounters a plateau with a steep escarpment, and, when he has climbed it, he has still 150 miles to go across a bleak, rolling surface not unlike the Lincolnshire wolds-especially in

\footnotetext{
${ }^{1}$ The frontier between the East Roman Empire and the Arab Empire.
} 
winter, when the great open fields are either miry or frost-bound or covered deep in snow (as I found them at Ushaq in February 1921). Scrubby oaks and irregular outcrops of rock, rising her and there into mountains, hardly break the monotony or diminish the openness of the country. Roads and railways are rare, and the soil unfavourable for transport apart from them. They are also devious; for while it is only 250 miles as the crow flies from Smyrna to the western edge of the desert, it is $2621 / 2$ miles by railway to Afium Kara Hissar, which is hardly more than half-way towards the desert from the escarpment of the plateau. In the end, when the desert is reached by the centre of an advancing army, the gaps on either side leave that army's flanks as much exposed as ever.

The problem of closing these gaps against counter-attacks is made more difficult by the fact that the plateau—which covers the almost the whole peninsula except the 100-mile wide strip of lowland along the western coast—has a rim of mountains. Successive tiers of parallel ranges, running roughly east and west, separate the interior from both the Mediterranean and the Black Sea coasts; and these ranges push out westwards, outflanking the lowlands and the routes up the river valleys, till their last spurs plunge into the Aegean Sea. On the north flank there is the miniature range of the Karamursal (or Yalova-Gemlik) promontory, the mighty Mysian Olympus towering above Brusa, and the vast mountain labyrinths of Simav and the Troad. On the south there is a similar labyrinth round Mughla. I looked out at the snow-covered mountains of Simav through a periscope, from the northern sector of the Greek lines round Ushaq, on the $3^{\text {rd }}$ February 1921 . On the $15^{\text {th }}$ of the same month, I climbed the ancient acropolis of 
Tralleis to gaze across the Maeander at the mountains of Mughla. In the following summer, I also acquainted myself with the Karamursal district, as will appear in Chapter VII., and I can certify that all three fastnesses looked formidable to an amateur. From the Simav and Mughla fastnesses, the Anatolians of Xenophon's time used to harass the communications of the Persian Empire, while the still more venerable brigands of Karamursal gave trouble to the Argonauts. The same crags and forests served their Turcified descendants as bases for very effective operations against Greek military communications. They commanded the railways from Smyrna to Panderma, Kara Hissar, and Saraikeui, and the roads from Brusa towards Eski Shehir.

These outlying groups of mountains also give a strategical as well as a tactical advantage to the defence. They stand in the way of any concerted advance from the Marmara coast or the Gulf of Adalia in support of an invasion from Smyra. The routes leading inland from these other possible maritime bases only communicate with the valley routes from Smyrna round the eastern ends of the Simav and Mughla mountains - that is, at points 200 miles inland, as the crow flies, from the west coast. Till they have been carried this distance into the interior, operations conducted by the same invader from these three bases must proceed in dangerous isolation from one another.

These various geographical factors in combination tend, whenever Anatolia is invaded from the west, to produce a military front along one of two lines. The first line (described from the point of view of the defence) runs from north to south somewhere near the western escarpment of the plateau, with the 
right flank buttressed on the Simav and the left on the Mughla mountains. As long as this line is held by the defence, the invader is confined to the western lowlands, denied the possibility of concerted operations from Adalia or the Marmara, and harassed (if he has a competent opponent) by guerilla warfare against his communications. The second line, about 150 miles further east, also runs north and south, from the main northern to the main southern mountain-rim of the plateau, with the desert making a break in the centre and the wings respectively covering the two gaps between the desert and the mountains. This second line is perhaps technically less advantageous to the defence. It cuts its front in two, while it allows the invader to feed a united front from three maritime bases. On the other hand, it vastly increases the area which the invader has to occupy, lengthens his communications, leaves mountains hospitable to guerillas in his rear, brings him up on to the inclement plateau, and yet does not present him with a physically strong frontier which he can hold without effort. The defence, on its side, can still (though with difficulty and delay) co-ordinate its northern and southern sectors by communications east of the desert, and can carry on guerilla operations even more effectively than before. In fact, the second or more easterly line may give the invader a certain military ascendency, but not the means of terminating the campaign, while it seriously increases the drain on his national resources. At the same time, the difference in strategic value between these two lines is sufficient to make the area between them-a strip about 150 miles wide along the western edge of the plateau-the western key, in the military sense, to the mastery of Anatolia. For this reason it has often 
been a focus of war and government. The cradle of the Ottoman Empire was the district between Söyüd and Aski Shehir, where the route from the Marmara mounts the north-western escarpment. The citadel and sepulchers of the Phrygian kings, and Amorion, the principal fortress of the East Roman Empire in Anatolia, were both situated between the desert and the mountains of Simav. Conforming to the same permanent geographical conditions, the recent GraecoTurkish campaign turned principally upon the control of a section of railway running north and south, over this part of the plateau, from Eski Shehir to Afium Kara Hissar.

This railway forms the junction between the five following important lines of communication:

(i) The railway from the west coast (Smyrna to Afium Kara Hissar);

(ii) The route, mostly by road, from Adalia (Adalia to Afium Kara Hissar, using a few kilometres of railway north of Buldur);

(iii) The route into Central and Eastern Anatolia through the southern gap (the track of the Anatolian and Baghdad Railways from Kara Hissar to Konia, Eregli, the Taurus and Amanus Tunnels, and Nisibin);

(iv) The route from the Marmara (either from Haidar Pasha by railway, or from Mudania mostly by road, to Eski Shehir);

(v) The route into Central and Eastern Anatolia through the northern gap (from Eski Shehir to Angora and then eastwards, through Sivas and Erzerum, into Russia). 
This convergence of routes gives the Eski Shehir-Kara Hissar railway undoubted strategical importance, but only for an invader disposing of forces and resources commensurate with the size of the country. It is little use securing the key if you cannot take possession of the citadel, and this citadel is so vast that the garrison, even if it abandons the gate, has almost boundless room to retreat and manœuvre before it finds its back against the wall. Eski Shehir and Kara Hissar, distant though they seem when you arrive at them from the coast, are only on the outer fringe of Anatolia. Two tables of distances sufficiently illustrate this fact.

Take a map and a pair of dividers and fix one limb at Kum Kalé, almost the most westerly point on the Anatolian mainland, lying on the fortieth parallel of latitude at the entrance to the Dardanelles. Then move the other limb eastwards, diverging a little to measure the respective distances from the Dardanelles to Söyüd (where the Marmara routes unite and mount on to the plateau, N.N.W. of Eski Shehir); to Angora (the Nationalists' capital); to Sivas (their reserve capital); and finally to Erzerum (their last fortress before they retire into the vast hinterland of Russia). The following distances will be registered:

(i) Dardanelles to Söyüd, 200 miles.

"Angora, 350 "

"Sivas, 570 “

"Erzerum, 800 " 
This is as the crow flies. By railway, the following distances have to be traversed from Smyrna:

(i) Smyrna to Kara Hissar, 420 kilometres $=262 \frac{1}{2} 2$ miles.

(iv) Smyrna via Eregli to Kaisaria, ${ }^{1}$ about 1120 kilometres $=$ about 700 miles

(v) Smyrna to Eski Shehir, 582 kilometres $=364$ miles.

$$
\text { " " Angora, } 845 \quad 528 \text { " }
$$

'"Won't you walk into my parlour?" said the spider to the fly.'

The moral of these figures is reinforced by historical precedents. Western Anatolia has sometimes been conquered, or partially conquered, successfully overland. The Phrygians and Mysians achieved this about the twelfth century, and the Galatians in the third century B.C. from the northwest, coming across the Straits out of the Balkan Peninsula. It has also been conquered from the northeast by Powers already in possession of the east and the centre of the countryin the sixth century B.C., for instance, by the Persians and in the thirteenth century after Christ by the Turks. All these conquests except the Persian,

\footnotetext{
${ }^{1}$ The section from Eregli to Kaisaria being by road.
} 
however, were tribal migrations, not annexations by a foreign state situated beyond the boundaries of the country. There are even fewer instances of conquest from the west coast by a foreign state situated overseas.

The Ancient Greek colonies of the twelfth century B.C. (on which Modern Greece largely founds her claim to 'lonia') are not a case in point, for they too were planted by emigrants who retained no political connection with the country from which they came. They were not colonial possessions of any Greek state or states on the other side of the Aegean, and in the seventh and sixth centuries B.C. they were annexed without difficulty by the Kingdom of Lydia, the first considerable land-power that arose in the interior of Western Anatolia after their foundation. Soon after the middle of the sixth century, they were taken over, with Lydia, by the Persian Empire. About 499 B.C. they revolted and received some naval and military assistance from the independent Greek overseas. But though Athens was not three days' sail away, while the capital of Persia was three months' journey overland, the insurgents were reconquered.

In 479 B.C., however, they slipped out of Persia's hands again, in a moment of demoralisation due to the disastrous failure of Xerxes' invasion of European Greece, and an interesting controversy immediately arose between the two leading states in the victorious Greek alliance.

'The Allies held a conference to discuss the evacuation of the civil population of lonia, and debated where to settle them in the parts of Greece at their disposal, supposing that they abandoned Ionia to the Orientals. It seemed to them out of the question that 
they should remain under arms for ever protecting the lonians, and without their protection they had no hope of the lonians successfully measuring themselves against the Persians. The Peloponnesian Governments accordingly proposed to evict the inhabitants of ports belonging to nations in Greece which had sided with the Persians, and to hand the districts over to the lonians to settle in. The Athenians, however, would not hear of any evacuation of Ionia or accept proposals from the Peloponnesians in regard to a population of Athenian origin. ${ }^{1}$ They raised such violent opposition that the Peloponnesians gave way. ${ }^{2}$

The result was that a war which had already lasted, off and on, for twentyone years (499-479 B.C.) was prolonged to fifty-one (499-449 B.C.) and terminated by a mutually unsatisfactory peace. The terms of it are obscure, because the Athenians referred to them as little as possible and the Persians never wrote their own history. Apparently, the lonian cities on the mainland remained members of the Athenian Confederacy but were 'demilitarised'-their fortifications being dismantled ${ }^{3}$ and their territories declared neutral ground. No doubt they paid double tribute to the sea and the land power which had made peace at their expense. Afterwards, the fratricidal conflict into which Greece fell in 431 B.C. gave Persia an opportunity of reasserting her claim to sovereignty;

\footnotetext{
${ }^{1}$ In the conventional mythology, the original lonians were settlers from Attica.

${ }^{2}$ Herodotus, ix. 106. Compare the anecdote in v. 50.
} 
and then, when Athens had at length succumbed to Spara, the Ionians appealed to King Agesilaos to carry on the Anatolian policy of Pericles. Agesilaos landed troops at Ephesus and delivered a series of offensives against the Persians (3995 B.C.), over much the same ground and with much the same results as the operations conducted from the adjacent base of Smyrna in 1919-21. Victories were gained and territory was occupied, but with no effect upon the enemy's will to continue the war. Finally, the campaign was broken off by a diversion in the Balkans. Sparta was attacked by her neighbours, and Agesilaos evacuated Anatolia on an urgent summons from his Government. For eight or nine years, the countries round the Aegean relapsed into general warfare. Then, in 386 B.C., peace was negotiated in European Greece by Persian mediation, and the broker's fee was a formal recognition, by all states 'consenting to the peace,' of Persia's sovereignty over the Anatolian mainland. ${ }^{1}$

Then there are the conquests of Alexander-jubilantly trumpeted by the Greek Press of all parties in 1921, whenever their troops advanced. The 'Gordian Knot' was to be cut once again by General Papulas! They forgot that Alexander had not after all outwitted the oracle. Whoever untied the knot was to rule Asia. Alexander cut it, and destroyed the Persian Empire (which had tied the Middle East together for two centuries) without founding another. His enduring achievements were negative. By overthrowing the Oriental world-state he threw open the Middle East to Hellenic civilisation, but he did not permanently annex to

\footnotetext{
${ }^{3}$ See Thucydides, iii, 33.2; viii. 14.3; 16.3; 31.3; 62.2; 107.1; also Xenophon, Hellenica, i. 2. 15 ; 5. 11.

${ }^{1}$ As well as the islands of Klazomenai and Cyprus.
} 
his ancestral kingdom of Macedonia either Western Anatolia or any other of the vast territories which he overran. After his death, Western Anatolia was fought over for more than a century by rival Powers-a Greek kingdom at Antioch, pushing up north-westward along the modern route of the Baghdad Railway; a Greek kingdom in the Balkans, first in Thrace and then in Macedonia, which never secured any hold; a Greek kingdom in Egypt, operating coastwise from overseas; local Powers like Pergamon (a revived Lydia) and the city-states of Cyzicus and Rhodes; and the immigrant Galatian tribesmen. In the midst of this political anarchy, Hellenic civilisation only made progress in Anatolia because there was no counter-influence like Islam in the field against it (the civilisations of Mesopotamia and Egypt being remote and by that time enfeebled). Moreover, even this cultural progress was comparatively slight until it was assisted by the Roman conquest and political unification of the country.

What happened after the annexation of Western Anatolia by Rome illustrates the immense difficulty of any permanent conquest of that country from overseas. The moment was extraordinarily propitious. By 133 B.C., the west of the peninsula had been united for fifty-six years under a local Government (the Kingdom of Pergamon) protected and aggrandised by Rome, and the remainder was divided among a dozen petty states; all likewise clients of Rome, jealous of one another, and united by no community of language, religion, or national feeling. Rome was the only surviving Great Power in the Mediterranean world. She annexed light-heartedly, sent her officials to take possession, and was involved in an interminable succession of wars. Roman imperialism had by that 
time made its reputation, and peoples overshadowed by it fought desperately to beat it off. The late king's bastard raised chettés, declared his conversion to Bolshevism (styling his outlawed followers 'Citizens of the City of the Sun'), and gave Rome trouble for three years (131-129 B.C.). Later, Mithridates of Pontus, one of the client princes of the centre and east, took up the struggle with welldrilled troops, well-filled coffers, and an effectively administered territory; drove the Romans into the sea and followed them into the Balkans; started a second round after barely losing the first; and threatened to let loose on the West an avalanche of invasion from the steppes of Russia. Mithridates evoked something like an Anatolian national feeling, and as he had no quarrel with contemporary Western culture, the Hellenised minorities sometimes took his side. Before the Roman Government had finished with him, they were as sick of the names Mithridates and Pontus as the British Government latterly became of Mustafa Kemal and Angora. They had to spend stupendous sums, send gigantic reinforcements, and put Pompey, their best general, in command with unprecedented military and political powers. Pompey did finish Mithridates, but his remedy was almost worse for Rome than the disease. Before he slipped away to the Crimea, the enfant terrible of Ancient Anatolia had led the Romans a dance to the Caucasus and the Euphrates, and they were never able to shuffle back. At the other end of Anatolia they encountered a new Oriental Great Power (the strongest since the fall of Darius) with a military technique that baffled them and the formidable backing of a popular anti-Hellenic reaction. The best that Pompey could do was to trace a frontier for Rome from the Caucasus to the 
Arabian desert, and for seven centuries (64 B.C.-A.D. 628) Rome shouldered the burden of Atlas. The frontier-wars grew more frequent, more violent, and more long-drawn-out; they turned into wars of religion; and after the last and longest, in which each combatant received and inflicted mortal wounds, the Arab tribesmen rushed in under the sudden intoxication of Islam, and at once blow felled Rome and Hellenism. If only the Modern Greeks would study Ancient history without sentiment, it might be an antidote instead of a stimulant to their disastrous romanticism.

After taking in this background, one can look back in better perspective over the course of the last Anatolian campaign. The problem for the Greeks was not simply to occupy manu militari a certain zone in Western Anatolia, but to maintain effective political sovereignty there after reducing their garrison to a peace-footing. They had not only to drive the enemy out of the territories which they wished to hold. They had either to find defensible positions of such strength that they could be indifferent to chronic border-warfare, or else to break the enemy's will and power to continue the war so absolutely that he would be compelled to accept satisfactory terms of peace and to observe them for an indefinite period, however weak in themselves or weakly-held the Greek frontier defences in Anatolia might be. The first alternative solution was a 'scientific' frontier, like the mountain-frontier of British India or the desert-frontier secured by the French in Syria and Algeria. The second was a 'knock-out blow,' like that delivered by the Allied Armies on the Western Front in the summer and autumn of 1918. One can discern the interplay of these two ideas in the minds of the 
Greek Staff as one traces the course of their operations. Almost every time that they advanced, some ideal 'scientific' frontier was their objective. Yet every time that they reached a new line, it disappointed their expectations, and they veered round -always too late-to the alternative strategy of annihilation.

The Turks, on their side, had, first of all, to reconstitute their army and keep it in being, sacrificing territory to avoid hazarding a decision. Ultimately, they had either to drive the Greeks into the sea or force them to evacuate Anatolia through national exhaustion. The first method had recently been applied with success in several similar situations. During the European War the Turks themselves had forced an Anglo-French Army out of the Gallipoli Peninsula; the Germans had forced the Belgians out of Antwerp; and, on a much larger scale, the Bolsheviks had forced the troops and Governments of Denikin and Wrangel out of Southern Russia, Odessa, and the Crimea-though the 'Whites,' like the Greeks in Anatolia, had been backed by Allied diplomacy, warships, and munitions. On the other hand, in a parallel situation, the Central Powers had failed to dislodge the Allies from Salonika. The precedents for a military decision in favour of the Turks were thus doubtful, while the economic and psychological conditions prevailing after the European War were favourable to the method of exhaustion. During the summer of 1920 the Arabs of Mesopotamia induced the British Government, by such tactics, considerably to relax their hold upon that country, and the common factors in Mesopotamia and Anatolian military geography have already been noticed. On the whole, the Turkish Staff were consistent in refusing battle when the Greeks attacked in superior strength, and 
the moral of the Turkish nation stood the repetition of this depressing strategy. The judgment of the military leaders was more often at fault during the Greek retreats. They assumed too readily that the Greek troops would be demoralised by the strategic failures of their commanders, counter-attacked rashly and unskillfully, and wasted to no purpose strength which they could ill afford to lose. In nearly every Greek offensive, after initial Greek successes, the Turkish defence was successful in the decisive phase, and then the Greeks were heartened again by being enabled to punish Turkish attempts to hinder their retreat.

It is worth glancing at the several stages in this curious struggle. ${ }^{1}$ The first lasted from the landing of the Greek troops at Smyrna in May 1919 to the May of 1920. The Supreme Council had sanctioned a Greek occupation without defining the area! And the Greeks, after disembarking under cover of Allied warships, naturally pushed inland, as fast as they could go, up the railways leading to Aidin and Manysa. They met with no serious resistance, for under the Allied armisticecontrol the Turkish regular army had by that time been reduced to less than

\footnotetext{
${ }^{1}$ It must be noted that the south-west corner of Anatolia was artificially excluded from the field of operations by the presence of detachments of Italian troops at Scala Nuova, Sokia, and on the south bank of the Maeander opposite Aidin, as well as at Adalia. The only operations here were raids by Turkish chettés into the Greek occupied territory from behind the screen of Italian troops, which prevented the Greeks from retaliating by punitive expeditions. But in any case this district would not have been the scene of major operations in this particular war, because the centre of the Nationalist power-both military and political-was located in the northern gap leading round the desert from Western to Central and Eastern Anatolia, so that it would have been difficult for the Turks and useless for the Greeks to make great military efforts in the opposite corner of the peninsula. On the other hand, the route from Adalia to Angora west of the desert was valuable to the Turks as an inlet for supplies, and it was therefore important for the Greeks to cut it; but they could do this at Afium Kara Hissar more effectively than at any point south of the Maeander.
} 
20,000 effectives. The temporary recapture of Aidin town was the work of Turkish chettés, and only happened because the Greek Staff (making hay while the sun shone) had pushed forward too quickly and the local Greek commander had lost his nerve. This reverse, though it incidentally ruined the richest country and the most promising provincial city in Western Anatolia and caused appalling suffering and misery, ${ }^{1}$ had almost no military importance. Aidin was reoccupied after a day or two, and when the Allies, awaking too late to their responsibility, sent a commission of inquiry and fixed a local armistice-line, the towns and districts of Aidin, Ödemish, Manysa and Bergama, as well as Smyrna, were left in the Greeks' hands. The Greek Staff had thus secured elbow-room for holding Smyrna and its maritime approaches, but they had not advanced beyond the lowlands or encountered regular troops. There they sat for a year and waited for the Treaty of Sèvres, while in the interior the Nationalists' military organisation went forward.

The second stage began in June 1920 and lasted until the following December. The Greeks advanced again, but this time, instead of merely omitting to restrain them, the Supreme Council, or at least the British Government, encouraged them to go on. A succession of events in the spring had created an awkward situation for the arbiters of the world. In January the Nationalists had put out their claws and raided a dump of Ottoman war-material which had been

\footnotetext{
${ }^{1}$ See Chapter VII., pp. 273-4.
} 
deposited, in pursuance of the armistice, in the Gallipoli Peninsula. ${ }^{2}$ The formal occupation of Constantinople and the deportation of militant Nationalists in March had not overawed the Turks but exasperated them. In April, while the details of the Treaty of Sèvres were being settled finally at San Remo, the Allied detachments and control-officers in Anatolia were being withdrawn to escape internment, and Damad Ferid Pasha's Circassian irregulars were retreating towards the Straits. When the official summary of the Treaty was being published in May, the Allied Governments were privately facing the disagreeable alternatives of a humiliating evacuation of Constantinople or the dispatch of reinforcements for which they dared not ask their respective nations. The Nationalist forces were already working round the flank of a British battalion stationed at Ismid. They attacked it about the $15^{\text {th }}$ of June, and when the news reached England, Mr. Venizelos, who had arrived in anticipation of it, offered to pull the chestnuts out of the fire. There was a conference at Boulogne, and French military experts—correctly calculating the Nationalists' potential strenth— uttered warnings against acceptance. But the British Government could not risk a disgrace at Ismid which would have eclipsed Kutu'l-Amara. Turkey was a beaten enemy and appearances must be kept up. The French Government, too, had political temptations. A Greek offensive might give them relief from the unpopular war in Cilicia and an opportunity to conquer Eastern Syria from the

\footnotetext{
${ }^{2}$ An armed party landed from the Asiatic shore, disposed (by what methods?) of the French guards, loaded large quantities of material on lighters, tugged them across the Dardanelles, unshipped them, and transported them into the interior at leisure!
} 
Emir Feisal. The statesmen hovered between the arguments of their colleague and those of their expert advisers. In the end, a Greek offensive was authorized, but geographical limits were laid down. The Greek forces were to interpose themselves between the Nationalists and the Straits, and in reward they were to occupy Eastern Thrace (in anticipation of the Treaty of Sèvres) and additional territory east of Smyrna which even the Treaty did not assign to Greece; but they were not to advance to Kara Hissar or Eski Shehir.

The Greek operations, thus sanctioned, were promptly started on the $22^{\text {nd }}$ June and were rapidly and brilliantly executed. There were four simultaneous movements. ${ }^{1}$ One force advanced northwards from Manysa along the Panderma Railway, which threads its way, between the mountain-tangles of the Troad and Simav, to the south coast of the Marmara. East of Panderma there are lowlands again, and Brusa was occupied by the Greek cavalry ranging ahead of the other arms. A second force advanced simultaneously eastwards from the Hermus and Cayster valleys to Alashehir, at the foot of the escarpment, and then, in August, up to Ushaq on the plateau. A third force, further south, moved from Aidin in a parallel direction up the north bank of the Maeander, to a point from which there were easy communications with Ushaq and Alashehir. A fourth force, consisting of a single division, was sent by sea express to Ismid, and relieved the pressure on the British battalion, while Mudania and Gemlik were also occupied from the sea by Graeco-British naval and military units. 
The strategy of these operations was good, ${ }^{1}$ the marching and moral of the Greek troops excellent, the Turkish resistance negligible. The Nationalist forces either retreated without offering battle (as at Brusa) or were driven headlong (as in the neighbourhood of Alashehir). Within less than a fortnight everything was over except the subsidiary advance to Ushaq, and the British and Greek Premiers were laughing at the French generals who did not even know (or perhaps had slyly pretended not to know) their own business. In the circumstances it was natural for the statesmen to assume that the soldiers had been disingenuous, but the truth was that the soldiers—rightly including politics in their military calculations—had been the better politicians. Probably they had foreseen all along that the Greeks could successfully cover the Straits and so save the Supreme Council from the immediate political necessity of taking cognizance of Turkish Nationalism; but they had also foreseen that the Greeks could not break up the Nationalist military organisation, and that they would subsequently be weakened, from the military point of view, as a result of their advance. There would be no compensation for this military disadvantage unless the Turkish National Movement were crippled politically by a military retreat, and of this, as it turned out, there was no symptom. The Turkish leaders were not discouraged, because their new army was not yet ready and they had never expected their chetté screen to be a match for Greek regular troops. They had

\footnotetext{
${ }^{1}$ Omitting the occupation of Thrace (an admirable piece of work from the military point of view), which had no direct bearing on the problem of Anatolia.

${ }^{1}$ No doubt the staff of the British Army of the Black Sea contributed to the plans. The British Navy, too, took part whenever possible, while the French and Italians, though they had assented to the offensive, rather ostentatiously abstained from participation.
} 
intended all along to barter territory for time (their manœvring ground was so immense that, militarily, they could well afford it), and they had no fear of a political debacle. Backward nations are not neurotic, and the Russian strategy of 1812 could be followed with impunity by the Turkey of 1920 . What were Brusa and Ushaq? The Eski Shehir-Kara Hissar Railway, the key to Western Anatolia, remained in the Nationalists' hands, and their busy reorganisation of the army had suffered no interruption. ${ }^{1}$

The Greeks, on the other hand, experienced some disillusionment as their exhilaration subsided and the winter came on. They had exchanged a continuous front in the lowlands near their base for three fronts isolated from each other and each ill-connected with Smyrna. The division encamped at Ismid for the benefit of the Allies had only sea-communications. The railway from Smyrna to Panderma was exposed to attack by guerillas, while between Panderma and Brusa there was no railway at all. In the third place, their southern front had been pushed up on to the plateau. Within six months of its occupation, Ushaq had acquired an unpleasant reputation in the Greek Army, and when I saw it under winter conditions in the February of 1921, I sympathised with their repugnance. The defences had been organised with reasonable thoroughness, and the enemy screen of chettés had retired out of contact. But

\footnotetext{
${ }^{1}$ The Greek occupation of Ushaq, Brusa, and Ismid not only did not discourage the Turks, it did not even deter another Moslem population from following their example. The Arab rising in Mesopotamia began at this very moment and lasted till the autumn, just as the most serious of the risings in Egypt had occurred a few months after Lord Allenby's great victory over the Turks in Palestine.
} 
Ushaq was at the tip of a salient enclosing like a sheath the last twenty-five miles of the railway from Smyrna, and the bridges and tunnels by which the line wound its way up the escarpment of the plateau were uncomfortably vulnerable. The two divisions ${ }^{1}$ stationed at the further end of this potential trap had much to put up with and little to do. They despised the enemy whom they had driven before them so easily the preceding summer, and did not realise that they were soon to be confronted with better trained and equipped formations. This was demoralising, and it was made worse by the change of government in Greece and the consequent change of personnel in the army of Anatolia. The commander-in-chief was replaced first, and a few weeks before the campaigning season of 1921 began, the majority of the previous Venizelist corps and divisional commanders were superseded by officers who did not know the troops, the country, or even in many cases the latest developments in the art of war. $^{2}$ If there was to be another 'walk-over,' Royalists generals were to reap the laurels. Meanwhile the Turkish High Command worked hard behind the scenes, and did nothing at the front to disturb their opponents' illusions.

The third phase lasted from January to April 1921. Before the winter was over, the Royalists were feeling so acutely the drawbacks of the position in which the had been landed by the Venizelists' 'limited' offensive, that their hearts were set upon Kara Hissar and Eski Shehir. So long as he held these places and the

${ }^{1} 13^{\text {th }}$ (Khalkís) and $2^{\text {nd }}$ (Athens), both composed of men from the Aegean, accustomed to milder winters. 
railway connecting them, the enemy possessed the interior lines, while the Greek front was discontinuous and not conveniently accessible. Drive him out and the tables would be turned. His right and left wings, pushed back respectively on Angora and Konia, would be separated by the desert, while the Greek front would be reunited and served by a continuous chain of railway from Smyrna to Ismid. What had prevented the victorious Greek Army from taking Eski Shehir and Kara Hissar the previous summer? Obviously, the limitation suggested to the Supreme Council by the malice of the French General Staff and weakly accepted by Mr. Venizelos. But the King had always stood for independence towards the foreigner. He would not hamper Greek generalship by submitting to servitudes imposed by the Powers, and the refusal of the Allies to recognise his Government had at least this advantage that it absolved them from any obligations that the preceding Government might have contracted. Confidently, Greece took a free hand to finish the war, ${ }^{1}$ leaving out of account the potentialities of her adversary.

\footnotetext{
${ }^{2}$ Some had been interned in Silesia by the Germans, many more by the Venizelists in the Archipelago, and all these had seen no active service since the Balkan Wars.

${ }^{1}$ It is impossible to say whether the Greek forces under arms in the summer of 1920 were really strong enough to advance much further than they did, if the Allies had sanctioned it. But it is certain that this would have made very little difference to the course of the campaign. Before the Greeks could have reached the Eski Shehir-Kara Hissar line, the Nationalists could have evacuated their training camps and arsenals eastwards, and the remaining stages of the campaign would merely have been fought a hundred miles or so deeper in the interior. As has been explained, this western key to Anatolia is still only on the fringe. The 'limitation' laid down in June 1920 at Boulogne, like the armistice-line traced on the summer of 1919, is chiefly interesting for the light it throws on the Supreme Council's muddle-headedness. Were the Greeks allies and the Turks recalcitrant defeated enemies, or were they both naughty boys? The Supreme Council could never make up their minds. Logically, either they themselves had done wrong in sending the Greeks to Smyrna, or else the Nationalists deserved no mercy. They would not admit the former alternative, but had not the nerve to act ruthlessly up to the latter.
} 
In January 1921, the Greek Northern Army made a reconnaissance in force from Brusa, struck the Anatolian Railway where it penetrates the north-west escarpment of the plateau through the Karakeui Defile, and got within sight of the upland plain of Eski Shehir. They met with little resistance and retired unpursued, deciding to repeat the excursion when the weather was milder and their delegates had tried their luck at the forthcoming conference in London. ${ }^{2}$ Evidently the chettés were as contemptible as the year before-but this was the fatal error in their calculation. This time the new Turkish Army had been almost but not quite ready. It had been timed to be ready by the spring, and the January raid had taken it by surprise. But it profited by the warning, and during February and March, while the conference was dragging on ineffectively in London and the Greek forces at Brusa were marking time, the Turks were fortifying the approaches to Eski Shehir as feverishly as they had fortified the Dardanelles in 1915 after the first naval bombardment.

The conference came to nothing, and on the $23^{\text {rd }}$ March 1921, the Greek Northern and Southern Armies took the offensive simultaneously from Brusa and Ushaq. After encountering stiff resistance, the Southern Army occupied Kara Hissar, but the three northern divisions beat in vain against the heights which they had taken in their stride two months before. The approaches were now swept by a well-served artillery; the slopes were scientifically entrenched; and the trenches were manned by troops who held their ground. After several days'

\footnotetext{
${ }^{2}$ See Chapter III. above.
} 
murderous fighting, the Greek $7^{\text {th }}$ Division on the right carried the Turkish positions opposite them with the bayonet and looked down once again upon the plain of Eski Shehir. ${ }^{1}$ But the Turks had reinforcements and the Greeks had none; the Greek centre and left were pushed back over the escarpment; the right had to follow, and the failure of the Northern Army necessitated a strategic retreat of the Southern from Kara Hissar. By the $4^{\text {th }}$ April the Greeks were back in their old lines. They had lost heavily with no result. They could only congratulate themselves that they had escaped destruction. On the $2^{\text {nd }}$ and $3^{\text {rd }}$ April, as I walked back the forty-odd miles to Brusa with the $7^{\text {th }}$ Division-an interminable procession of troops, mules, ox-carts and lorries crawling along a foundered road-we could not make out why no enemy attacked us from the mountains commanding our southern flank. It turned out that all Turkish units still fit for action had been sent south to cut the railway between Kara Hissar and Ushaq. They nearly succeeded, and the Southern Army's retreat was only kept open by the gallantry of a single regiment in reserve at Tulu Punar.

The Greek failure, as I can testify, was not due to the rank and file, who fought with the same determination as their opponents and retreated in good order, but to the staff. Although they had command of the air, and the eventual battlefield was within easy reach of their aerodrome at Brusa, they had apparently obtained no intelligence of the new Turkish entrenchments and formations. Expecting to meet nothing but chettés and to disperse them as

\footnotetext{
${ }^{1}$ This ridge above the village of Kovalyja was held by the Greek $7^{\text {th }}$ Division from the $29^{\text {th }}$ March
} 
easily as before, they did not regroup their forces, but simply sent forward on each front the divisions that had been in winter quarters there. The three northern divisions were thus thrown without reserves against fortified positions at forty to fifty miles' distance from their base at Brusa and with no communications but roads never intended for motor transport. The Turks had railways at their disposal and made bold use of their interior lines in order to concentrate on the defence of Eski Shehir-deliberately risking the temporary loss of Kara Hissar, on the sound calculation that the Greeks could never retain it if they were repulsed on the principal battlefield. These causes alone would account for the result, but the Greeks could not get over their surprise at the transformation of the chettés into soldiers, and scented the 'hidden hand.' The Turkish artillery must have been served by Russian or German gunners to make such good shooting, Italian sappers must have traced the trenches, French officers have kept the infantry steady. I convinced myself to my own satisfaction that this was a hallucination, ${ }^{1}$ and in reality there was no puzzle to solve. There had been many trained soldiers in the Old Ottoman Army, and they had had rather more opportunity than the Greeks of learning from the European War. The Greeks' unchallenged ascendency during the preceding two years had been due to the fact that, before their landing, the Allied control had broken up the Turkish military machine. By the spring of 1921 the Nationalist organizers had assembled it again, and at the battle of In Önü ${ }^{1}$ Greek and Turkish regular forces had met for

to the night of the $1^{\text {st }}$ to $2^{\text {nd }}$ April. I visited it on the $1^{\text {st }}$ April. (See 'The Battles of In Önü,' p. 249.)

${ }^{1}$ See 'The Origin of a Legend,' pp. 254. seqq.

${ }^{1}$ So named after the principal village on the battlefield. 
the first time in the Anatolian War. The repulse of the Greeks under the first test of these conditions was the turning-point in the campaign. ${ }^{2}$

There was a certain inevitability about the stages that followed, but neither party had yet put out their full strength, the season was young, and before autumn there was time for a more extensive slaughter. The Greek Government began to gamble. They mobilised class after class ${ }^{3}$ and multiplied their artillery and munitions. The drachma dropped, the people grew restive, but who would shrink from a few months' strain with a prospect of victory? Deliver the 'knockout blow, and the drachma and King Constantine would recover their credit. This fourth phase lasted from the $5^{\text {th }}$ April 1921 to the $21^{\text {st }}$ July. Ninety-five days were consumed in suspense and preparations, twelve in the supreme effort to obtain a victorious decision.

In the Greek offensive launched on the $10^{\text {th }}$ July 1921 there was no failure of strategy. The most able of the Royalist officers, General Dúsmanis, who had been trained in Germany and had distinguished himself in the Balkan War, had been entrusted, as Chief of the General Staff, with the working out of the plans. ${ }^{4}$

\footnotetext{
${ }^{2}$ The Greeks were naturally tempted to dispute this, and to attribute the Nationalist Army's achievements almost entirely to French, Italian, or Russian assistance-just as the Turks explained the Greek successes in 1920 as being the result of British support. It is true that both parties did receive foreign munitions and diplomatic encouragement, and the Greeks-down to the return of King Constantine-actual naval and military support from Great Britain. But each party over-estimated the foreign contribution to the fighting power of the other.

${ }^{3}$ Including the troops already under arms, eleven classes from Old Greece and twenty-one from the provinces acquired after the Balkan War appear to have been mobilised by the beginning of the July offensive, besides considerable numbers of Ottoman Greeks impressed by compulsory levy in the occupied territories.

${ }^{4}$ I understand that at least the outline of the plans actually adopted was suggested by a young Venizelist staff-officer of the $3^{\text {rd }}$ Corps, who had not been deprived of his post like his chief, General Nidher. It might not be discreet to mention this officer's name, but if the story is true, it
} 
This time the first objective was Kiutahia, a town a few miles west of the Eski Shehir-Kara Hissar Railway and about equidistant from the two termini. The principal concentration was on the southern front, which was directly connected with the Smyrna base by railway. The strongest column moved due north from Tulu Punar-the position in advance of Ushaq which the Greeks had successfully held in the April retreat and had never abandoned. A second column was sent north-east to make a wide encircling movement through Kara Hissar. A third—from Brusa—was timed to meet the Tulu Punar column outside Kiutahia by a daring march through the mountains. On this occasion the Greeks reached their objectives. The converging columns met; Kiutahia fell; the positions covering Eski Shehir were turned from the south, and the encircling column threatened the garrison's railway communications with Angora. Eski Shehir was evacuated and occupied by the columns which had taken Kiutahia, and only then the remaining Greek forces at Brusa sallied out for the third time to the In Önü battlefield, walked through the abandoned Turkish defences, and arrived in turn at Eski Shehir. On the $21^{\text {st }}$ July the Turkish Army attempted to recover Eski Shehir from the Greek forces wearied by eleven days' fighting and marching, but reunited. This counter-attack failed, the Turks broke contact, and the operations came to an end, leaving the western key of Anatolia in the Greeks' possession.

Had they got a decision? Their strategy had been as good as the summer before, and though the reservists were not equal to the seasoned troops that had 
fought in the European War, their marching and fighting powers still impressed foreign military attachés. They had taken the long-coveted positions of Kara Hissar and Eski Shehir, only—as in 1920—-the Turkish Army had again eluded them. During the first two months of preparations and counter-preparations, the Turkish Staff had been keeping careful watch upon the relative increase in strength of the opposing forces, ${ }^{1}$ and about a month before the Greek offensive they again decided not to risk standing on their positions but to barter territory for time. The decision was singularly clear-sighted. Laboriously constructed and successfully defended fortifications were scrapped, the arsenals, munition-works, and training-camps at Eski Shehir dismantled, sentiment thrown to the winds, and, the moment the Greeks moved, the bulk of the Turkish Army withdrew. The defenders of Kiutahia were a devoted rearguard. ${ }^{2}$ The forces which counterattacked at Eski Shehir were virtually intact, and they did not this time weaken themselves by persistence. They slipped away eastwards again into the interior and dug themselves in on the east bank of the Sakkaria and its tributary the Gök Su, covering the western and southern approaches to Angora. The decision on which the Greeks had gambled had been successfully postponed.

\footnotetext{
trained by British officers on the Salonika front.

${ }^{1}$ A few days before the Greek July offensive, I learned from a first-rate Allied military source that the Turkish regular army had by then risen to 200,000 men from the 19,000 which had been its strength in May 1919.

${ }^{2}$ Apparently one strong and one weak Turkish division were left at Kiutahia, with orders to retreat after fighting a delaying action for twenty-four hours. The weak division carried out its instructions. The commander of the strong division was heroically insubordinate. He fought on and, after inflicting heavy losses, was killed with the majority of his men.
} 
The fifth phase ${ }^{3}$ lasted from the $22^{\text {nd }}$ July to the $23^{\text {rd }}$ September 1921. Jaded by an unprofitable victory, and with no further military prospect of terminating the war, the Greeks pushed forward through the northern gap towards the boundless hinterland of Central and Eastern Anatolia. It was a crazy enterprise, for every rational objective had disappeared. The annihilation of the enemy? Three times already that stroke had missed its aim. The occupation of his temporary capital? As if the loss of Angora would break a Turkish moral which had survived the loss of Constantinople, or would prevent the Great National Assembly from resuming its activities at Sivas or Kaisaria. Everything was against the invaders. The three bare weeks which they gave themselves for recuperation were time enough for the Turks to prepare their new positions, and the incidents of the battle of In Önü were repeated on a larger scale. Starting on the $14^{\text {th }}$ August, ${ }^{1}$ the Greeks halted and marched and halted again for ten days before they found themselves face to face with their opponents. The heat and drought and malignant malaria of summer were more cruel than the frosts of early spring. They exhausted themselves by a detour through the desert which was to turn the Turkish left flank, and then apparently changed their tactics to a frontal attack. They delivered the attack on the $24^{\text {th }}$ August and kept it up till the $4^{\text {th }}$ September. Once more, as at In Önü, some divisions fought their way

\footnotetext{
${ }^{3}$ A very clear and convincing account of it was written by the Times correspondent at Constantinople. See the Times of the $14^{\text {th }}$ and $24^{\text {th }}$ October 1921. There is also an official account from the Greek side by Stratig[h]ós, X., of which an English translation (place and date of publication not indicated) has been printed, with excellent maps.

${ }^{1}$ I take my dates from the Greek official account.
} 
through the last line of the Turkish defences and only had to halt because their neighbours had failed to make equal progress. The attack was within an ace of success at the moment when it became evident that it had failed. Then, on the $8^{\text {th }}, 9^{\text {th }}$, and $10^{\text {th }}$ September, Turkish counter-attacks showed the necessity for a retreat. Next day it began, and again, as in April, the Turks failed to prevent it. By the $13^{\text {th }}$ September the Greek Army had withdrawn west and north of the loop of the Sakkaria without further disaster, and were trailing back, devastating the country as they went, to Eski Shehir. The site where Western archaeologists had located Alexander's Gordion lay on their road. Would a Greek army ever penetrate that distance into Anatolia again?

From that moment it became evident that the Anatolian campaign would not be terminated by a military decision. The Greeks had shot their bolt without either striking a scientific frontier or transfixing their enemy, but the Turks had also missed their chance. In attempting to march on Angora the Greeks had delivered themselves into their hands, and they had let them escape. If they had been unable to destroy them on the battlefield east of the Sakkaria, when the Greeks' attack had failed and Turkish cavalry were raiding their communications, they could have little hope of driving them by force out of Eski Shehir and Kara Hissar, still less of driving them into the Aegean. From the military point of view, stalemate had been reached and further offensive operations by either party were foredoomed to failure. The remaining alternatives were mediation by the Western Powers or a passive contest of national endurance. The role of the Powers has been discussed in Chapter III., but while Western diplomacy was 
making further revelations of its bankruptcy in Eastern affairs, Greece and Turkey were drifting towards collapse.

Which would break down first? There was a stubborn spirit in both the fighting forces. The Greek divisions in Anatolia before the mobilisation of 1921 were mostly troops who had fought on the Salonika front in the European War and had had a varied experience in Bulgaria or Southern Russia before they came to Anatolia. They were accustomed to much hotter artillery fire, their moral had been fortified by participation in the Great War on the victorious side, and they were proud of having had French and English troops as comrades in arms. They were wonderfully good marchers; capable of sustained attacks against prepared positions; not easily demoralized by casualties; stoical and cool-headed in retreat. Of course, by the time of the retreat from the Sakkaria, the remnants of these divisions had been swamped by the reservists, but they too had seen service in the Balkan Wars and had the expectation of victory. The only really bad troops were the Thracian and Anatolian levies. At the battle of In Önü, the $10^{\text {th }}$ (Asia Minor) Division had been the first to give ground.

The Turkish troops on their side consisted of three categories-regulars, volunteers, and local chettés. I had a glimpse of all three from the $29^{\text {th }}$ June to the $2^{\text {nd }}$ July 1921 at Ismid, and was impressed by their discipline. The chettés were undoubtedly under the Army's control. The volunteers, who came like the regulars from distant parts, were properly organised units. The regulars 
themselves, in spite of their miscellaneous uniforms, were unmistakably fine soldiers. I saw them in circumstances of extreme provocation, ${ }^{1}$ but they stood the test. There had been no retaliation upon the churches for the state in which the Greeks had left the mosques; no wrecking of the deserted Greek and Armenian shops, though the sign of the cross still remained chalked on their shutters to distinguish them from the Turkish shops, which the Greeks, before they left, had systematically looted; no violence against the few native Christians who had remained, in revenge for the previous massacre of Turkish civilians. The sale and consumption of alcoholic liquors had been effectively prohibited by the military governor. At night the town was quiet, the troops sober and orderly, and a Westerner could walk the streets in the dark with no adventures except courteous challenges from sentries and the offer of a lantern to light him on his way. Ismid was an outlying theatre of operations, and the best Turkish divisions were at that time concentrated behind Eski Shehir in anticipation of the Greek offensive, so that the troops that I happened to see were not likely to have been exceptionally favourable examples of the Nationalist Army.

Their temper differed from that of the Greeks. They had fewer illusions. They were not the spoilt children of fortune or of Western sentimentality nor intoxicated by historical romance. While, like the Greeks, they had been at war for years, they had generally been beaten, so that they had no mental capital of self-confidence or exhilaration to draw on. They were simply going on fighting so 
long as an invader remained on their soil. I was particularly struck by the quiet determination of the officers taken prisoner by the Greeks at the battle of In Önü, whom I visited a few days after in their place of detention at Brusa. They were all reservists, and not one of them, I think, had spent less than four out of the last ten years on active service. They were mostly small landowners-yeomen or squires_-and came from such parts as Konia and Kaisaria, in the centre and east of Anatolia, well beyond the range of possible Greek invasion. They had thus no personal or parochial interests at stake, and to have been taken prisoner recently is a depressing position. But these men did not display a trace of irresolution. After frankly admitting their weariness of war, they added in a matter-of-fact way that this war would be carried on by the Turkish nation until the Greeks had evacuated all Anatolia. In fact, the difference in temper between the Greek and Turkish armies was not unlike that between the Germans and the French in the European War. The Turkish soldier had the immense moral advantage of resisting an invader, and fighting in his own country gave him material advantages as well. He was accustomed to the climate, and had the sympathy of the majority of the population.

With the individual Greek soldier, chivalry towards the Anatolian Greek minorities was perhaps the strongest motive for enduring hardship and disappointment and exile from home. The minorities had suffered during the ten years before the Greek Army came; they had welcomed the Army as their deliverers and shown them hospitality and kindness. European Greek soldiers had married Anatolian wives. The minorities had been compromised by the 
Greek occupation, and their protectors had no confidence that, if they left the country, their kinsmen and co-religionists would be shielded effectively by Western intervention from Turkish reprisals. During their brief ascendency, the minorities had in many cases more than paid off old scores against the Turks, and were unwilling to risk another settlement of accounts with them. At the end of June 1921, when for purely strategic reasons the Greek forces voluntarily evacuated the enclave round Ismid and the Yalova Peninsula, almost the entire native Christian population accompanied them, and, in view of their record, it can only be said that they were wise. ${ }^{1}$ Still, migration means ruin and suffering, whether the parties have brought it on themselves or not. The spectacle was unpleasant for the retiring troops, the disposal of the refugees embarrassing to the Greek Government. In Cilicia, during the winter of 1921, the departure of the French garrisons produced a civilian emigration on a larger scale. The appalling prospect of more than half-a-million Greeks fleeing destitute from all over Western Anatolia under similar conditions, steeled the Greek Army to face an uncomfortable present and a blank future. Yet the Moreot or Macedonian conscript was fighting overseas, and Anatolia was for him a foreign country. $\mathrm{He}$ could not be expected to hold out to the same extremity as if the front had been on the Vistritza or the Sperkhiós instead of the Sakkaria and the Maeander, or as the Turkish soldier would hold out to defend his national home-lands.

${ }^{1}$ See Chapter VII. 
At this stage, however, the issue depended even more upon the temper of the civilians. I had no opportunity of observing this in the Nationalist territory, but I was struck by the confident spirit that prevailed in Constantinople and Smyrna. The Turkish inhabitants of the capital and of the principal port of Turkey were living under foreign military occupation, but they never seemed to doubt that sooner or later the Nationalist troops would march in; and though, during 1921, those troops were constantly retiring further into the interior, their confidence was perceptibly increasing. They seemed to feel instinctively that Turkey could hold out longer than Greece. 'Nous les aurons' they were saying after In Önü, 'Nous les avons' after the Sakkaria.

During the battle of the Sakkaria I was observing the 'home front' in Greece. There was little to be learnt in Athens, for in August (as in the preceding January) party politics were engrossing people's attention. The 'general post' of placemen-from cabinet ministers down to elementary schoolmasters-was still going on. Whose place had been, or was going to be, given to whom? Everybody in the capital was making or losing his career, and personal interest was bound to thrust into the background the national question of the war, in spite of the steady arrival of wounded and the progressive conversion of public buildings into military hospitals. I spent my time in the country. For ten days I walked about in the Morea, sleeping in the villagers' houses, talking with them over the evening meal, and continuing the conversation on the mountain-tracks next morning; and afterwards I made a more rapid excursion into Western Macedonia. The Morea was the heart of 'Old Greece' and had been solidly 
Royalist. The Greeks of Macedonia had only been united to the Kingdom after the Balkan War, and, like most of their newly liberated kinsmen, had been supporters of Mr. Venizelos. The Moreots are provincials, the Macedonianslinked up with the West by railway more than a generation ago-are comparatively in touch with the world. By visiting both and comparing impressions, I got some notion of the general state of feeling in the country.

They were in a puzzled state of mind, accepting with strange credulity their newspapers' assurances of an immediate victorious conclusion of the war, yet full of uneasiness at the growing economic pressure. In three days Angora was to fall; in three months King Constantine was to march into Constantinople; the Turkish resistance was broken; in this hundredth year after the beginning of the War of Independence they were to see the realisation of the 'Great Idea.' Crudely coloured broadsheets of their King riding over the corpse of the Turkish dragon through the Golden Gate, with his namesake the last East Roman Emperor riding at his side, were passed from hand to hand, and the children were repeating doggerel prophecies, but there was no atmosphere of elation. The people seemed like a long-distance runner who thinks that he is winning the race but wonders if he has dangerously overstrained himself. Even in conversation with a stranger, they spoke less of the supposed victory than of its cost—of the young men absent for years at the war and of the remorseless rise in prices.

The depreciation of the drachma seemed to have had a greater effect than separation from sons and husbands and shortage of hands in the fields. The fall 
had not been great compared to that of other European currencies or of the Turkish pound. The drachma still stood higher than the Italian lira. But the political importance of the exchange is largely psychological, and a rapid fall of moderate extent may demoralise a country more than one three times as great spread over six times the period. The financial position of Greece had been exceptionally favourable during the European War. The internal struggle of parties had prolonged her neutrality, and she had earned handsome profits froom her merchant-marine. The armistice left her with the drachma above par and with the expectation of prosperity. It was a depressing experience to be reduced unexpectedly to the level of her neighbours and to drift on at war while they were all returning to more normal conditions. ${ }^{1}$ Moreover, an equal depreciation in her case involved greater actual hardships, for while Jugoslavia, Bulgaria, Rumania, and still more Turkey, were mainly agricultural and proportionately selfsupporting, the national livelihood of Greece was dependent on her foreign trade. She exported currants, tobacco, olive oil, oranges, emery and other specialized

\footnotetext{
${ }^{1}$ Fluctuations of the Drachma.
}

Date. Number of Drachmas to the Pound Sterling on the London Exchange.

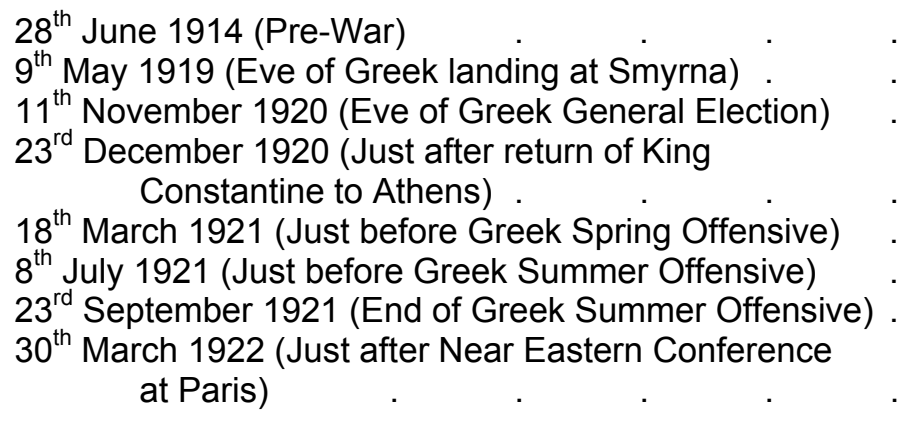

$104.50-106.50$ 
agricultural products and rare minerals; she imported in exchange a large part of her clothing and food. Depreciation therefore raised the cost of living for almost every family in the country. It hit the peasant and shepherd as well as the merchant, ship-owner, and financier. On the other hand, the heavier fall in the Turkish pound was felt less severely by the population of the Nationalist territory. They were living on their own production, with almost no imports except munitions of war presented to them gratis, or on long credit, by their backers. There was terrible hardship among Turkish officials and pensioners and refugees at Constantinople-a great over-crowded city, competing for its supplies in the world-market, and deprived of the revenues and commerce of Anatolia. Indeed, the Angora Government would have found the defence and maintenance of Constantinople during their war with Greece as great a burden as Petrograd was for the Moscow Government while they were fighting the 'Whites' and the Poles. But the Allies had relieved them of this responsibility, while the Greeks themselves had relieved them of Smyrna—a port as indispensable to Turkey in peace and as superfluous in a campaign against an enemy commanding the sea as Odessa is to Russia. The Nationalists had no economic impedimenta and a minimum of military expense. Greece was hampered by a costly overseas war and a delicate national economy. As one takes the measure of this difference and its bearing on the contest of endurance into which the war had lapsed, one perceives that it was another product of the omnipresent factor of Westernisation. By Westernising earlier and more radically, Greece had gained many advantages in her long struggle with Turkey—she had gained education, skill, wealth, 
organisation, and foreign sympathy. But to purchase all this she had had to attach herself to the economic system of the Western world, and that systemthough its fruits may be desirable in peace and though its energies can be diverted, by a tour de force, to strike titantic blows in a war of decision-is illadapted to stand the strain of a war of exhaustion. The Turkish strategy had achieved its object. It had prolonged the Anatolian conflict into a stage in which Greece's Western accomplishments were a handicap and Turkey's relative imperviousness to Westernisation (the cause of so many of her past misfortunes) was working in her favour.

\section{THE BATTLE OF IN ÖNÜ}

[Narrative written at Brusa on the $5^{\text {th }}$ April 1921.]

I arrived at Greek headquarters here the day the Southern Army took Afium Kara Hissar, and before the Turkish defensive on the Eski Shehir front had proved itself more than a match for the three Greek divisions attacking there. During the next two days I became conscious of a growing tension at headquarters and of a dearth of news. The situation on the northern front was settling down from a war of movement into a war of position like that on an old western front in France, without either side possessing the resources in men and munitions of which the combatants in the European War disposed. Something must snap soon on one side or other, and I decided to get as far forward as I could before the crisis occurred. Though the Greek military authorities must have suspected by then that the break would come on their side, they gave me 
every facility, and I hope that what I witnessed and shall describe will repay their frankness and hospitality.

I went up to corps headquarters in an empty motor ambulance returning early in the morning after bringing down wounded to Brusa the day before. It was a long day's journey, for there were two steep gradients to climb, and the Greek motor transport-a legacy of equipment from the Great War-is the worse for years of campaigning on the roads of Macedonia and Anatolia-roads metalled for ox-carts and not for heavy motor transport designed for use in France. As we climbed painfully up the heights of Nazyf Pasha, that separate the plain of Ainegöl from the plateau of Pazarjyk (a journey that I repeated on foot in the reverse direction several days later), I began to realise on how narrow a margin the Greeks had gambled for a military decision in Anatolia, and how adverse were the circumstances under which they were playing for victory over Kemal.

That evening we reached Pazarjyk, the headquarters of the corps that we conducting the offensive, and next morning another lorry, loaded this time with artillery ammunition, carried me on towards the $7^{\text {th }}$ Division, which was holding the Greek right wing. Dumps of material and parks of arabas (ox-carts) announced our approach to the scene of operations. Then suddenly the road plunged down from the plateau in curves between low hills, past some carcases of animals, and we found ourselves running parallel with a river and a railway track along a deep defile. 
The place was infested with the atmosphere of war, which makes inanimate hills and valleys seem malevolent and adds something sinister to the most ordinary landscape. But this place was haunted by history as well. That railway, with its magnificent embankment and culverts and bridges intact, and even its telegraph wires uncut, but with neither rolling-stock nor staff, was the Anatolian Railway — the first section of the Baghdad line. In its derelict condition it seemed symbolic of a great nation's frustrated ambitions. The giant had fallen, and smaller people were fighting for this fragment of the heritage which the German had marked out as his own. But that smoke rising above the hill to our left front as we dipped into the ravine was symbolic too. It marked the site of Söyüd, the first Anatolian village possessed by the ancestor of the Ottoman Dynasty, and now the Osmanlis were fighting for their national existence on the very spot where that existence had begun. Ertoghrul, the father of Osman, coming through the defile from the south, had founded an empire which in two centuries spread north-westward to the Danube. To-day, along that line of hills through which the defile made its way, the Greeks were fighting for a lodgment to the south-east which might eventually give them the empire of all Anatolia.

As we approached the southern end of the defile, the guns began to be heard. That afternoon it was too late to visit the front line, and I sat there discerning nothing but the extreme tension in the air. There was an extraordinary silence, only emphasised by the occasional faint sound of artillery from the other sectors. A column of smoke began to rise sluggishly from behind the hill to our left rear (I afterwards discovered that it was the burning of Boz Oyuk, the 
attractive little town through which I had ridden up a few hours before). As it grew dusk, this smoke caught the reflection of the unseen fire below, and stretchers came down slowly from over the hill to our left front, where the artillery observers were standing on the sky-line. Then as the light vanished it grew suddenly very cold. I was invited into a tent and went to sleep. Evidently the battle to-day had been on the other sectors, and its issue there would decide our division's action.

Dawn was like the evening. A stretcher moving down very slowly, intense cold, and a clinging, bewildering mist. But I had a whole day before me, and I asked the chief of staff if I might visit Kovalitsa, ${ }^{1}$ the Turkish position which the $7^{\text {th }}$ Division had taken at great cost the day before I came. He pointed to the skyline of the mountain straight in front of us, two or three kilometres away. 'There it is,' he said; 'go when and where you like,' so I started away. I will confess that I did not enjoy going off alone through the mist up that empty valley to the sky-line with the Turks beyond it, though I was more afraid of sudden death from some Greek patrol, which might fire at a man not in Greek uniform without waiting to inquire whether his papers were in order. But no one took any notice of me. I caught up a sapper on his way to join the divisional detachment of engineers, who were reorganising the captured Turkish positions on the hill, and we climbed up the slopes together through the mangey oak-scrub. He had been in America,

\footnotetext{
${ }^{1}$ The Greek transcription of Kovalyja.
} 
and we talked alternately in English and Greek. On the top I fell in with the divisional commander of engineers, and we walked round the position together.

As the sun rose and the mist cleared away it became evident how magnificent the position was. The Turkish trenches facing north commanded the southern exits of the defile through which I had come the day before. From the crown of the hill a rift in the mist suddenly revealed a corridor of plain stretching away towards Eski Shehir, with nothing between us and it except a low ridge, a mile or so off, on which a few Turks were still visible through the periscope. To our right rear the great snow-capped Mysian Olympus that towers above the city of Brusa, appeared unexpectedly through a gap in the nearer hills (that gap often recurred unpleasantly to my mind when we were retreating next day). The summer which I had ascended was one of the three or four that constitute the Kovalitsa ridge, and the position must have been a terrible one to attack. All along the northern rim of the crest there was a tilted outcrop of limestone scrag, turning the slope for a few yards into a precipice, and here, where the nullahs met the scrag, lay most of the Greek dead (the Turkish dead, killed by shell-fire, lay in their trenches).

I wondered how any one could think the military possession of those summits worth the price, and then I looked down the plain of Eski Shehir and thought of the historical consequences which the capture of those summits might involve. I had not realised yet that, even from the military point of view, they had been captured in vain. 
I know that retreats have been described too often already. The general features of all retreats are probably the same. But perhaps any one who has taken part in one has a right to describe it again. As far as I was concerned, this particular retreat began when, after having seen all I wanted of Kovalitsa, I made my way back downhill towards divisional headquarters, but I did not know this till four o'clock next morning. I thought that I was merely going down to find some lunch, and that I should have time to visit Kovalitsa again before the division descended from Kovalitsa into the plain and advanced to Eski Shehir.

As a matter of fact, I was already disturbed on my own account (though no doubt not nearly so acutely as the divisional staff) by the exposure of our left flank. During my outward journey to Kovalitsa there had been a burst of rifle fire which sounded disconcertingly near to divisional headquarters. The cannonading, which broke out furiously when I was on the top of Kovalitsa and then rather suddenly stopped, seemed to come not only from our left, but from very much to our left rear. When I got down to headquarters I found only officers and telephones. Tents and baggage had gone. Where should I find my rucksack? At Karakeui, a little way back. Inquiries for Karakeui led me right back to the northern end of the defile, where the road zigzagged down from the Pazarjyk plateau, and where, the day before, I had first encountered the atmosphere of war. I found my baggage and determined to stick to it, which let me in for an exasperating series of marches and counter-marches with the baggage train of the divisional staff up and down the defile. I should think the site of our camp for the night was settled and unsettled half-a-dozen times. Late 
afternoon passed into evening, and the little town of Boz Oyuk went up in brighter and brighter flames, illuminating not only the smoke but the surrounding hills.

Finally, towards 10 P.M., we got the order to pitch the tents where they had been the night before. A rumour came that there had been a great battle on the $10^{\text {th }}$ Division's sector in the centre; that the $10^{\text {th }}$ had repulsed all attacks, and had counter-attacked in turn; and that a Greek aeroplane had seen the Turkish forces retreating in confusion. As a matter of fact, that morning the $10^{\text {th }}$ Division, holding the Greek centre, had been pushed so far back that our own retreat through the defile had been menaced for several hours, and the airmen had reported that fresh Turkish divisions were coming into line. At the moment when the staff's baggage was moving up to its old position, a general retreat had already been decreed.

I was dozing (one could not sleep consecutively for the cold) against the outside of a tent, when some one came round and began to pull up the pegs. As I got up I found the mules already being loaded. The battery under the hill limbered up and fell into line in front of us. The cavalry mounted and followed. We moved out, but back and down the valley, passed through the streets of Boz Oyuk, where the fire was now at its height, and turned once again into the road leading northward up the defile. It was a weird march, between 4 A.M. and dawn, in choking dust transfused with moonlight and reeking with the odour of animals and men. I did not in the least realise our danger, and I am sure that 90 per cent. of the column were as unaware of it as I. 
Then we passed out of the defile, left the road where it wound away up to our left, and unloaded the mules in a field by the railway. We were told that this was to be our position for the day, and I was thinking of wandering back to corps headquarters to get news of the other divisions, when an urgent order came for us to load and start again. There was a visible impatience among the men, who were already very tired. Where were we to go? To Pazarjyk or beyond? The orderly only knew that we were to go backward and start at once. By a side track we regained the main road, and then the truth burst upon us. The field artillery were well ahead. The heavy guns, drawn by motor lorries, were lumbering up another road that made a junction with ours. Even the infantry were emerging from the defile. It was a general retreat, and heaven knew how far we were to go.

Being a mule train and belonging to the divisional staff, we made our way through the fields at a faster pace than the column, and were able to survey it from one end to the other before the close of the day. I must record my admiration of the discipline and good temper which the retreating division maintained from beginning to end, and I was an eye-witness of the $7^{\text {th }}$ Division's retreat from the moment it left the valley below Kovalitsa till the time when, on the second afternoon, one section after another of the interminable column passed through the wire entanglements and trenches which they had held twelve days earlier, before the offensive began, and settled down in their old quarters to hold their old line. 
The men were angry—angry at spending so much blood and labour in vain, but even more humiliated at a defeat which broke a long record of victory of which they had been intensely proud. A great deal is written about the southern temperament and its tendency to give way under adversity, but the temperament of a crowd (whatever may be the case with individuals) is not innate and unchangeable, but is the product of habit and training. This crowd, whose bearing in adversity I was privileged to witness, was a body of men toughened and knit together by four years' experience of modern warfare. They had learnt much from their contact with the other Allied armies of the Salonika front, and this training was not to be undone by one reverse, however bitter or however serious it might be. Certainly the quality of this veteran division came out in adversity more than when they were still confident of success. Heavy guns, field guns, mountain artillery, lorries, ox-carts, and mules-all were safely brought away, and such ammunition as could not be transported was blown up.

The single road along which we were moving was badly broken up by the constant passage of heavy traffic, and ox-carts and motor transport seemed equally apt to break down. But the break-downs were repaired, the stream of wheeled traffic was kept constantly moving in single file, the mules were passed along in parallel columns across the fields, and officers were detailed to direct the movement at bridges and fords. As we emerged from the defile, the cavalry were sent back through it to keep the Turkish cavalry in play, the mountain artillery was sorted out and kept at the rear of the column, and the heavy artillery was hurried on towards the van. 
There was no panic and little confusion, and yet our situation was not a comfortable one. The positions we had just left were at right angles to the old positions, covering Brusa, to which we were retreating. The road we were following roughly described the arc of a circle, seventy kilometres long, with the concave side towards the enemy. Would the enemy cavalry move along the chord of the arc and cut into our flank before our journey was done? But no enemy appeared. We camped that afternoon at 2 P.M. on the Nazyf Pasha heights, between the plateau of Pazarjyk and the plain of Ainegöl. We did not leave them till 3 A.M. next morning, and it was not till we had safely passed through barred and bolted Ainegöl town, and were nearing the further heights, where we were to stand, that any Turkish cavalry made contact with our rearguard.

I marched through Ainegöl with the divisional commander of engineers and bivouacked with his detachment for half an hour just beyond. The mules were ranged in line and unloaded, and, the day being Sunday, a church parade was held for the men. That was the end of my walking. My friend put me into a passing motor lorry which dropped me at the crown of the hill, just above the wire and trenches of the period before the offensive, which the division was to reoccupy again. From the bank above the road I commanded a marvelous view of kindly Olympus, the plain and town of Ainegöl, and the Nazyf Pasha heights on the horizon, eight hours' march away. I sat there watching the immense procession and looking out for the mule which was carrying my knapsack—I 
could identify him because he was also carrying two deal folding tables belonging to the divisional staff.

As I watched, one of two oxen yoked to a cart just below me lay down deliberately in the road, and the whole file of carts, guns, and lorries halted behind him for miles. It was a dramatic act on the part of the ox, for there, far away on the road zigzagging down into the plain from Nazyf Pasha, I could see the dust raised by the Turkish cavalry as they came down at last in pursuit. In some circumstances an ox may decide the fate of an army, but the driver of this ox was more than a match for him. After kicking and prodding the animal with no result whatever, he stooped down, picked up its tail, and, to my amazement, started carefully parting the hairs. Then, assuming a ferocious expression, he dug his teeth into the tail flesh. Perhaps this was an ultima ratio for dealing with oxen which had been handed down in the man's family for generations. Anyhow it worked. The ox got up with alacrity and walked on, the whole column followed, and I myself was caught up in a motor-car, whirled away to see the progress of the $3^{\text {rd }}$ Division, and finally deposited in a hotel at Brusa at two o'clock next morning, after a twenty-three hours' day.

\section{THE ORIGIN OF A LEGEND}

[Written at Constantinople on the $15^{\text {th }}$ April 1921.]

There is a widespread belief among the Greeks and Turks that Allied officers have been taking an active part in the recent operations on one side and the other. It has even been explained to me that this really a war between 
England and France for influence in Anatolia. The legend is founded on the fact—which the local nationalities know as well as we do-that the views of the Allied Governments on the Anatolian problem diverge. But only the megalomania which besets the minds of all nationalities, without exception, out here could suppose that this divergence over what is a very minor issue in world politics could break the Entente. The Entente is not going to be broken because the incorrigible 'Eastern Question' is a question still, and I have been able to ascertain at first hand (what I should have assumed á priori) that there have been neither British officers fighting on the Greek side nor French and Italian on the Turkish.

When I got back to Constantinople from the Brusa front the other day, I was assured by my Turkish friends, who had stayed in Constantinople all the time, that British officers had been directing the Greek offensive. There is, of course, not a shadow of truth in this. The truth is that officers belonging to all three Allied Powers were attached to the Greek Army to watch the operations. When the front was at Avghyn and Kovalitsa, I travelled from Brusa to the corps headquarters at Pazarjyk in the same lorry as an Italian officer and his orderlies. When I arrived at Kovalitsa, I found British officers examining the captured Turkish positions; and when I got back to my hotel at Brusa, I found a larger number of French officers there than the British and Italian attachés posted themselves in the Greek front lines and were visible from the Turkish positions.

The most ingenious periscope could not have revealed to the Kemalists the Italian officer at Pazarjyk or the French mission at Brusa. Why these latter 
gentlemen did not visit the front itself it is impossible for me to say. The Greeks will tell me that the reason was political-that France and Italy do not wish to lose favour with Kemal by being observed in Greece's company. I should be more inclined to attribute the lesser activity of the French and Italian attachés to their lack of motor-cars and horses, with which the British attachés were supplied, and also possibly to a difference of age, physique, and temperament. But I was considerably amused when I found a French garrison in the Brusa hotel, because I had just been hearing from Greek soldiers of all ranks that French officers were directing operations on the other side.

I watched this second legend spreading through the Greek Army and growing in dimensions hour by hour. First a French uniform had been observed in the Turkish trenches. Then an officer in French uniform had been bayoneted by an evzone in one of the Greek attacks, without having time to utter more than the single word 'Pardon.' And later, a long way behind the front, I met the evzone who had both killed the one and captured the other! The French had also inflicted casualties on the British. One of the English attachés, who had been shot by a Kemalist one day, was shot all over again by a French colonel the day after, and was welcomed by the waiters as one risen from the dead when he turned up at the hotel that evening for dinner.

A day or two later I went with this same British officer to visit the Greek and Turkish wounded who had been brought down to the Greek military hospital at Brusa, and we discovered the origin of the story. It had all arisen out of a new fashion in headgear (which in the East has a political significance that it does not 
possess in the West). An apparently unwounded officer, wearing a grey, Italianlooking uniform, with three stars on either flap of the collar, explained to us, in almost perfect English, that he was a Greek doctor from a village near Konia, who had been educated in the American College at Beirut, conscripted for the Turkish Army during the Great War, captured by the British Army on the Palestine front, released after the armistice from his internment in Egypt, and then, after returning home, had been conscripted a second time by the Kemalists. As we talked, he lifted some clothes lying beside his bed to look for a matchbox, and there, underneath, was his military cap. It was a round, flattopped thing of grey cloth, stretched on a stiff frame, rather like the képi of the old Austrian Army, except that it had two flaps buttoned together over the top and had no peak (for to wear a peak to your cap is contrary to the Muhammadan religion, because it would prevent you from touching the ground with your forehead when you prayed). The English major put on a solemn face. 'So you are the officer,' he said. 'What officer?' asked the poor Greek doctor a little nervously. 'The French officer who killed me,' replied the major, 'and that is the hat you did it in.'

Thus the cut of a cap is capable of starting a legend in the Near East which, if not treated with the proper skepticism, might ultimately have an adverse effect upon the relations of two Great Powers in Western Europe. Upon such evidence, it would be possible to start any legend you pleased. You meet Greek staff-officers wearing lion-and-unicorn buttons, and Kemalist prisoners turn up in U.S. Army greatcoats. When I visited the Turkish trenches captured by the 
Greek right wing on the heights of Kovalitsa, the only Turkish ammunition-boxes I saw there bore English inscriptions. I happened to know the history of this ammunition. It had been shipped to Batum and transported to Kars for the use of the Armenian Army several months ago, and had arrived at its destination the day before the Armenian garrison in Kars capitulated to the Kemalist forces on that front. In anticipation of the Greek offensive, the Kemalists had then carried it right across Anatolia and shot it off from these positions covering Eski Shehir.

Such are the material foundations of legends, but of course the cause, as distinct from the basis, of a legend is psychological. Why was the Greek Army, from divisional commanders down to privates, so ready to believe, on such inadequate evidence, that the army opposed to them was under French command? Neither I nor the British attachés nor any of our Greek informants had ever seen with our own eyes the French prisoner or the French corpse. Normally, grown men, even in the Near East, do not give credence to such grave charges as this on the strength of mere rumour. I think that in this case the Greek Army's 'will to believe' arose out of a very human desire to find some honourable reason for their failure to reach their objective. As a matter of fact, the record of the Greek combatant forces in this battle was honourable enough. They fought like lions_-attacking strongly-fortified positions for six days running without reserves. In these circumstances it was an almost irresistible temptation to believe, on the slenderest evidence, that the enemy who had baffled them was not a horde of chettés (brigands), but a great military Power. 
So the story of the French officers spread from mouth to mouth, and it was curious to see its effect upon the Greek Army's moral. At first it made them angry and combative. 'We should have got through the first day but for the French, and we shall get through now in spite of them.' But later, as victory failed to come, I could see how the rumour bred discouragement. 'We are not up against the Kemalists but against the French,' or 'How can we fight the French?' were phrases repeated to me during the last days of the battle by many Greek soldiers. If the Greek High Command are not sensible enough to explode this legend quickly, its ultimate effect on the Greek Army's moral may be extremely bad. But that is their affair. It is our business to see that Near Eastern legends without truth behind them do not trouble the good relations of England and France.

(map illustration entitled THE THEATRE OF WAR IN WESTERN ANATOLIA)

\section{VII \\ THE WAR OF EXTERMINATION}

THE policy of the Supreme Council towards Turkey and Greece is sufficiently condemned by the misgovernment, economic dislocation, war and military destruction which were its direct consequences. But Western statesmanship was also responsible in a measure for the atrocities which these engendered. Atrocities were, and were known by experience to be, the inevitable fruits, if these other evils were allowed to seed themselves and grow, and the experience 
was duly repeated in Anatolia. Armed men sprang out of the ground and slaughtered one another, but, as in the Ancient Greek legend, the heroes who had sown the dragon's teeth kept at a tactful distance from the shambles and expressed the horror requisite among sensitive Westerners when Orientals shed one another's blood.

This chapter is not an inventory of the outrages committed on the Greek and the Turkish side of the front during the Anatolian War. There have been official publications on the subject (or rather, on isolated halves of the subject) by the Sublime Porte and the Oecumenical Patriarchate, and two important reports by authoritative neutral investigators. ${ }^{1}$ My wife and I are also witnesses for the Greek atrocities in the Yalova, Gemlik, and Ismid areas, with which the reports of these latter investigators are largely concerned. We not only obtained abundant material evidence in the shape of burnt and plundered houses, recent corpses, and terror-stricken survivors. We witnessed robbery by Greek civilians and arson by Greek soldiers in uniform in the act of perpetration. We also obtained convincing evidence that atrocities similar to those which had come under our observation in the neighbourhood of the Marmara during May and June 1921, had been started since the same date in wide areas all over the remainder of the Greek occupied territories. My dossier of evidence is in order, and I should

\footnotetext{
1 1. Cmd. 1478=Turkey no. 1 (1921): Reports on Atrocities in the districts of Yalova and Guemlik and in the Ismid Peninsula (London, 1921, H.M. Stationery Office). [This White Paper contains two separate reports: (a) on the Yalova-Gemlik district by the senior members, and (b) on the Ismid district by the junior members of an Inter-Allied Commission of Inquiry sent to make investigations on the spot by the three High Commissioners at Constantinople.]
} 
publish it if I felt at any time that it would be useful to do so. But it has no proper place in this book, and it has been my misfortune to handle such documents so many times that I have no wish to repeat a very distasteful task. The genesis and nature of atrocities, as illustrated by occurrences since May 1919 in Anatolia, are the subject of this chapter.

How are atrocities to be defined? The demarcation between atrocities and acts of 'legitimate warfare' has varied in different generations of different societies. If our Western civilisation makes any further progress, all warfare may eventually be classed as an atrocity in our moral code, as on the other hand part of what we now so class was regarded as legitimate by our Western ancestors, and is still so regarded as legitimate by our Western ancestors, and is still so regarded in their heart of hearts by modern Near and Middle Eastern peoples. At present, however, there is a moral distinction in Western minds, drawn at a definite though constantly shifting line, which we have not yet transcended by abandoning the notion of 'legitimate warfare' altogether, and which younger contemporary societies have so far accepted that they do lip service to it and are ashamed to be detected when they transgress it. It seems important to keep this distinction clear ${ }^{1}$ while our neighbours remain inwardly unconverted and we ourselves are perpetually relapsing, though this is only desirable so long as the

\footnotetext{
${ }^{1}$ There was a division of Western opinion on this point during the European War. Some people felt that the implications of 'legitimate warfare' were so abominable that the idea was bound to do more harm than the complementary idea of 'atrocity' could do good by setting limits to it. These 'extreme pacifists' therefore agreed with the 'extreme militarists' (though for contrary reasons) in
} 
definition of 'atrocities' is all the time being extended so as to encroach upon and finally evict from our minds the hideous concept of a 'legitimate' infliction of physical injury on living creatures.

As we stand at present, 'legitimate warfare' may perhaps be defined as the infliction of every kind and degree of physical injury on enemy combatants not yet hors de combat, so long as it is inflicted with a view to success in military operations; 'atrocities,' as the infliction of any kind or degree of injury on anybody when it is not directed to this end. Whether the victims are combatants in action or hors de combat, non-combatants in a theatre of military operations, noncombatants behind the front, or soldiers and civilians in time of peace, to injure them without a military object is 'atrocious' or illegitimate.

When and how do atrocities in this sense occur? Nearly always when there is something abnormal about the general condition of society, and especially in the two abnormal states of war and revolution. Such states are not invariably accompanied by atrocities. Indeed, if they were, the distinction between atrocities and 'legitimate warfare,' being empirical, would hardly have arisen. But in these states atrocities are at any rate far more common than under conditions of internal and external peace. In peace they are rare-even in uncivilised or immature societies—except among populations morally divided by colour, nationality, religion, class, political tenets or any other potential cause of dissension, and then they may occur in otherwise humane and progressive communities. The mutual outrages of Moslems and Hindus in India, the 
massacres of Armenians by Turks in the Ottoman Empire, and the pogroms of Jews in Poland and Russia have their parallel in the lynching of negroes in certain states of the American Union and in the murder of Catholics by Protestants and Protestants by Catholics in Belfast. Under abnormal conditions, however, history proves conclusively that atrocities may also be committed in civilised societies of average homogeneity. The September Massacres, the Terror, and the war of extermination in la Vendée were possible in modern France during the Great Revolution; the excesses of the Commune at Paris in 1871 and its blood-thirsty repression were consequences of the Franco-Prussian War; the European War of 1914 occasioned both the German atrocities in Belgium and Northern France and the similar atrocities by 'Black and Tans,' Ulster Auxiliaries, and Sinn Feiners which occurred in Ireland after the armistice. Then there is the tale of political assassinations. That of the Arch-Duke FranzFerdinand may have partly provoked the War, but the War itself provoked the assassination of Jaurès, Stürgkh, Tisza, Karl Liebknecht, Rosa Luxemburg and Kurt Eisner. ${ }^{1}$

Atrocities, in fact, seem to be outbreaks of bestiality normally 'suppressed' in human beings but almost automatically stimulated under certain conditions, and that so powerfully, if the conditions are sufficiently acute or protracted, that the most highly civilised people are carried away. During the early summer of 1921, I was for some weeks in intimate contact with Greek soldiers and civilians then engaged in atrocities upon Turkish peasants, and with the survivors of their 
victims whom the Ottoman Red Crescent was attempting to rescue. My strongest impression during this horrible experience was of something inhuman both in the bloodthirstiness of the hunters and in the terror of the hunted. At the moment of embarkation, especially, when we were on the point of getting these defenceless men, women, and children, with a remnant of their worldly possessions, out of their tormentors' clutches, the tension used to mount and mount till it seemed as if the Greek soldiers and chettés must spring upon their prey. But for the presence of the three Allied officers attached to the Red Crescent Mission, I think they would have done so. They were furious at being cheated of their kill, and resisted the evacuation not only of men capable of military service but of old men, women, and children whose residence in the occupied territory was if anything a military disadvantage to the Greek Army. The Turkish survivors, on their side, were paralysed with terror, and could not realise that they had been rescued from their pursuers. Our interview on the evening of the $24^{\text {th }}$ May 1921 with the acting hoja of Akkeui is described in the separate narrative of our experiences at Yalova. ${ }^{1}$ A less painful incident two days later made a still more vivid impression. It was the early morning of the $26^{\text {th }}$ May on board the Red Crescent S.S. Gul-i-Nihal, at anchor in Constantinople harbour, waiting to pass the inter-Allied control. We had left Yalova the evening before, made our passage during the night, and the refugees with whom our decks were crowded were at last in safety, after months passed under the shadow of death. But they could not shake off the nightmare. Wishing to check

\footnotetext{
${ }^{1}$ Confining the list to Western countries and omitting half-Westernised Russia.
} 
the information that I had been collecting about the Greek chetté leaders, I went up to a fairly stalwart-looking refugee and asked him to repeat their names for me. At my question, the man burst into tears. 'How can you ask me their names, when we have had to leave some of our people behind at their mercy? If I tell you, they will hear, they will hear, and will take revenge on our relations!' Even in Stamboul harbour, the hunted animal was still under the fascination of the beasts of prey. Though we had left them on the other side of the Marmara, the breath of their pursuing still haunted his imagination. It was like some metamorphosis in classical mythology. In both hunter and hunted, the 'subconscious' pre-human animal had come to life.

The terror of the hunted is illustrated by the following passage, dated the $15^{\text {th }}$ May 1921, in the report of the Inter-Allied Commission: ${ }^{1}$

'At 4.30 the Commission landed at Kutchuk Kumlar [=Kuchuk Kumla], a village a bout $2 \frac{1}{2} \mathrm{kilom}$. from the point of debarkationi [i.e. the skala]. The houses on the beach were entirely destroyed, and one was in flames. Horses had been sent by the Greek general, who the day before had been informed of our intention to visit the village.

'The Commission made for Kutchuk Kumlar. Several hundreds of terror-stricken inhabitants, mostly women, were waiting for the Commission to land.

'It was difficult to obtain exact information, so great was the panic among the population, but it was gathered that a

\footnotetext{
${ }^{1}$ See 'Yalova,' p. 303.
} 
detachment of Greek soldiers and brigands had gone through the village a few days before and had returned that very morning, passing the Kumlar landing-place. The Commission returned on board, followed by the entire population, which placed itself under the protection of the Allies and refused to leave the beach, imploring us to take them to quiet and safety. That end of the jetty which was nearest to the "Bryony" was most densely covered with people. A letter was then written to General Leonardopoulos, asking him to take immediate steps for the protection of the village of Kumlar.

'It was only possible to hand him this letter at 6 A.M. next day. The "Bryony" remained at anchor beyond the landing-place, throwing her searchlights over the beach and the adjoining hills all night long, in order to reassure the refugees.

'May 16._At 9 A.M. the Commission landed, in order to collect all possible information from the refugees on the beach. One wounded and two dead men were brought along by the natives.

'The refugees stated that the day before a group of them, about twenty strong, tried to get to Guemlek in order to procure bread. They left the village, and, on arriving at the landing-place, met a detachment of Greek soldiers and brigands, commanded by a Greek officer. The women were sent back to the village, and the men were forced to follow the bandits. On the way some of the men were given

\footnotetext{
${ }^{1}$ Cmd. 1478 (1921).
} 
the order to return, and others were killed, the muktar being among the latter.

'At 10 o'clock the Commission reached the village, which was completely destroyed. A corporal and ten men sent by General Leonardopoulos (before the arrival of the letter sent that morning, which he could not have received) were on guard. The corporal was questioned by the Commission.

'On returning to the landing-place, a Greek staff officer, sent by the general commanding the Greek division, was waiting for the Commission. At the request of the latter he assured the refugees that they would be properly protected, a promise which had no effect on the population.'

The metamorphosis of the hunters into wild beasts comes out in a reminiscence of the Turkish atrocities against Armenians in Cilicia during 1909, recounted by an American eye-witness to Mr. W. J. Childs: ${ }^{1}$

'Grim silence and intentness on the part of the slayers, and the despairing silence of their victims, had been one of the most impressive characteristics of the scenes. And next, he said, had been the innate mercilessness and cruelty revealed in the character of those who killed; not in the way of torturing-

\footnotetext{
${ }^{1}$ Across Asia Minor on Foot (London and Edinburgh, 1917, Blackwood).
} 
of that he saw nothing — but in the insatiable desire to kill, and satisfaction in the deed.... The besiegers [of a house in which Armenians had taken refuge] were a crowd rather than a mob, a party of old men, young men, and youths, told off as if it were to this duty. Old men were their spokesmen, and the rest kept silence. But silent or speaking, they sat or stood patiently in the street before the door with foam on their lips, like waiting wolves.'

This is an ugly possibility in all of us; but happily, even when the stimuli are present, atrocities are seldom committed spontaneously by large bodies of human beings. Such outbreaks do occur. There was a bad case, described below, on the occasion of the original Greek landing at Smyrna. But more commonly the rabies seizes a few individuals, and is communicated by them to the mass, while in other cases the blood-lust of the pack is excited by coldblooded huntsmen who desire the death of the quarry without being carried away themselves by the excitement of the chase. There seems to be much evidence for this in the history of the French Revolution, but the most signal modern instance was the attempt to exterminate the Armenians in 1915. In this case, hundreds of thousands of people were done to death and thousands turned into robbers and murderers by the administrative action of a few dozen criminals in control of the Ottoman Empire. ${ }^{1}$ The atrocities which began throughout the

\footnotetext{
${ }^{1}$ On this point see Blue Book Miscellaneous No. 31(1916), pp. 651-3.
} 
Greek occupied territories in April 1921, were also organised from above, as I shall try to show. So far as it goes, this fact is a hopeful symptom for the eventual stamping out of the disease. But criminals by suggestion are guilty besides those who instigate the crime, and even if the extent of the moral disaster in such organised atrocities is less, that of the bloodshed and agony produced by them is generally far greater than when people simply run amuck. When once the stimuli are there, no amount of civilisation is a certain antidote against their operation. The only infallible remedy is prevention. Such stumbling-blocks ought never to be laid in the way of human beings, and for statesmen who lay them, however little they may have foreseen or intended the consequences of their action, 'it were better that a mill-stone were hanged about their necks and that they were drowned in the depth of the sea.'

These general considerations have a practical bearing on my subject, for they indicate that Orientals have no greater predisposition to atrocities than other people. Indeed, when the circumstances outlined in Chapters I. and IV. are taken into account, it will appear that the greater frequency of atrocities in the East has simply been proportional to the more intense operation of the stimuli there than in the contemporary West. If the history of Oriental atrocities is ever scientifically investigated, it will be found, I believe, that they have been worse during the last dozen years than during the rest of the last century, and worse again during that century than between the years 1461 and 1821 . If this proved correct, there would be a strong presumption that they were not endemic, and that the revolutionary process of Westernisation was one of their causes. The 
two curves of atrocities and Westernisation would practically coincide, and the true diagnosis of the atrocities might be that they were a prolonged epidemic, to which the Near and Middle Eastern societies were subject from the time when they lost their indigenous civilisations until they became acclimated to the intrusive influences of the West.

This view is borne out by the recentness (and precariousness) of cour boasted Western superiority. Educated Osmanlis are aware that the Spanishspeaking Jews who are so prominent in the principal cities of the Levant, are descended from the Jews of Spain, who were expelled by the Spanish and given asylum by the Ottoman Government at the close of the fifteenth century. Following up this clue, they have studied the martyrdom of the 'Moriscos,' the Moslem population of the Moorish states in the Peninsula reconquered by the Christians. They have read in Western histories how this civilised and industrious Middle Eastern people was forcibly converted, driven by oppression into desperate revolts, and then massacred, despoiled, and evicted by its Western conquerors, at the very time when in the Near East the Osmanlis were allowing conquered non-Moslems to retain their cultural autonomy and were organising Orthodox, Armenian, and Jewish millets as official departments of a Moslem state. I have heard Turks express ironical regret that they did not Westernise in the fifteenth century after Christ. If they had followed our example then, they would have had no minorities to bother them to-day!

It is undoubtedly true that down to the latter part of the seventeenth century the Middle East had the more tolerant tradition towards alien subjects, 
and this tradition was of Eastern derivation. It was based on Islamic law, which had been codified from the Qur'an and the Traditions during the first two centuries of the Arab Caliphate and largely embodied the practice of that empire. The status of the conquered communities is clear. ${ }^{1}$ Conversion or a super tax, not conversion or the sword (as is often believed in the West), was the alternative offered them; and as the super-tax was the backbone of the Imperial budget, the Treasury (staffed for the first two generations by Christian clerks) did not encourage the multiplication of true believers. This arrangement was not altogether inequitable, since, in return for the special revenue which it exacted from communities that capitulated on these terms, the Islamic Government guaranteed them protection, and the relationship between Moslems and 'clients' was regarded as a bilateral covenant. So long as the Government remained effective, the non-Moslems had little inducement to change their condition, and mass-conversions of Monophysites, Nestorians, and Zoroastrians to the ruling religion seem to have been uncommon until the ninth and tenth centuries after Christ, when the Empire was breaking up. There is little evidence that they were the result of official pressure. The more probable cause was that instinctive desire for a new social bond capable of surviving the impending break-down of civilisation, which-in the parallel circumstances of the fourth and fifth centuries after Christ-had produced mass-conversions to Christianity in the Western provinces of the Roman Empire.

\footnotetext{
${ }^{1}$ See Margoliouth, D.S., Early Development of Mohammedanism (London, 1913, Williams and
} 
This ancient Islamic tradition was inherited by the Osmanlis, was coordinated (in the millet system) with the new nomadic institutions of their empire, and has never entirely disappeared. During the last two centuries Ottoman subject communities have been massacred for pursuing Western-made political ambitions, but they have never, like dissenting subjects of Western Governments, been compelled to emigrate or else conform. One need not go back to the methods by which Saxons and Prussians (or the survivors of them) were brought by Charlemagne and the Knights of the Sword respectively into our Western fold. They do not compare favourably with the statesmanship of the Arabs, but they are an old story. On the other hand, one can fairly compare with the Ottoman Government's record the conduct of Western Governments since the Reformation. The principle of 'Cuius regio, eius religio,' on which the new map of religions were drawn by the mutual consent of the rulers in Western Europe, was repudiated east of the Turkish frontier, and in the seventeenth century Hungarian Protestants still preferred Ottoman to Hapsburg sovereignty. In France, the Edict of Nantes was revoked as recently as 1685, and in 1731-2 the Prince-Bishop of Salzburg expelled 30,000 Protestant subjects from his dominions. The diplomatic intervention of the King of Prussia barely secured them the privilege of selling instead of forfeiting their property. I can picture the sale, having seen one conducted in similar circumstances at Armudlu, on the 
Yalova-Gemlik Peninsula, on the $24^{\text {th }}$ and $25^{\text {th }}$ June $1921 .{ }^{1}$ Our Western ancestors were more provident than those of our Turkish contemporaries. In most Western states, they took the necessary steps, before the end of the seventeenth century, to secure homogeneity of population where it did not exist already. ${ }^{2}$ But in provinces like Ireland and Bohemia, where they scamped their work, their descendants have reacted to the same stimulus as the Turks and the Greeks in Anatolia.

In judging Greek and Turkish atrocities, Westerners have no right to be self-righteous. They can only commit one greater error of judgment, and that is to suppose that the Turks are more unrighteous than the Greeks. Much mischief has been done in the Near and Middle East by this common Western opinion. The argument generally advanced is that Turks have committed a very much greater number of atrocities upon Greeks than Greeks upon Turks since the two peoples first came across each other. The fact is true but the deduction is fallacious, because a second factor has to be taken into consideration, and that is the opportunities enjoyed by the two parties for respective ill-treatment. From 1461 to 1821 , very few Greeks in the world were not in the power of the Turks, while the Greeks never had considerable numbers of Turks in their power till

\footnotetext{
${ }^{1}$ The Turkish inhabitants were being evacuated by the Red Crescent. The Greek military authorities would not let them take away their cattle, but 'bought' the animals as a concession. The owners were cheated in three separate ways.

${ }^{2}$ The massacre of Glencoe, personally ordered by that model constitutional monarch William III., early in the fourth year of the 'Glorious Revolution,' bears an uncanny resemblance in motive and circumstance to the crimes of Young Turk rules against Armenians in the era of the Ottoman 'Hurriet.' But it needed the more systematic measures taken after 1745 to ensure that there should be no 'Gaelic Question' in twentieth-century Great Britain.
} 
1912. To obtain properly comparable figures (if one really can give quantitative expression to moral values), one ought to divide the total number of atrocities inflicted by each people upon the other by the number of its opportunities to inflict them, and then correct the result (if the evidence suffices) by the strength of the stimulus in each particular case. I shall not attempt this calculation, but I recommend it to any one who believes that there is much to choose between the Greek and the Turkish record.

In Anatolia there were both spontaneous and organised atrocities on either side after the Greek landing on the $15^{\text {th }}$ May 1919. The worst spontaneous outbreak occurred on that very day. The report of the Allied Commission of Inquiry has never been published, ${ }^{1}$ but I have obtained two independent accounts by eye-witnesses. One is a Western resident of long standing and distinguished position at Smyrna, who spent that morning in a house looking on to the sea-front. The other-an officer in the Royal Naval Reserve-was on board a British warship moored stern-on to the quay. ${ }^{2}$ The Greek expeditionary force was convoyed by a squadron of Allied warships with a British admiral in command, and, the evening before, the plan of disembarkation had been worked out at a conference of Greek and Allied officers on board the British flagship. The Turkish troops in the city had previously been disarmed by the local Allied control-officers, but they had not all been evacuated. A party, including a large

\footnotetext{
${ }^{1}$ See Chapter III, p. 79.

${ }^{2}$ See also 'The Greek Version of Events on the $15^{\text {th }}$ May 1919 and following days at Smyrna,' pp. 390 seqq. below.
} 
proportion of officers, still remained in the barracks behind the konak

(Government Offices), and to avoid the possibility of incidents, it was agreed that the Greeks should land unobtrusively at the two extremities of the city, march round the suburbs, and enter simultaneously from the land side. The meeting broke up, and next morning the Greeks landed at the middle of the quay! The Orthodox Metropolitan Bishop appeared to state to greet them; there were religious ceremonies and a national dance; and then the troops marched in column southwards, along the quay (the most conspicuous thoroughfare in Smyrna) towards the konak, with a mixed crowd of local civilians-Greeks, Armenians, Jews, and Turks-looking on. As they approached, the atmosphere grew electric, and when the head of the column came within a few hundred yards of the building, somebody fired a shot. I have met no witness of this fatal occurrence, and reserve judgment as to the side from which the shot came (each party of course attributing it with equal vehemence to the other). My witnesses, who were both at points further north, only heard the sudden fusillade that followed. It is certain that the Greek troops fired promiscuously into the crowd, killing and wounding Christian as well as Moslem civilians. One or two Christians were found lying among the wounded Moslem civilians when people came to attend to them and take them to hospital, and it was evident that they had been hit by the same volleys. The barrack-buildings were kept under so hot a fire that the Turkish officers inside had difficulty in displaying a white flag in token of surrender. When at length the signal was accepted and the Greek troops rushed in, these officers were formed into column and marched northwards along the 
quay. They had to hold their hands above their heads and shout either 'Zíto o Venezélos' or 'Zíto I Ellás'1 — they could choose which they preferred, so long as they shouted sufficiently loud to satisfy their captors. Some who stumbled or fell out of the ranks were immediately bayoneted by the Greek escort and their bodies pitched into the sea. ${ }^{1}$ Later, as they waited on the quay for further disposal, local Greek civilians were seen to snatch the rifles out of the soldiers' hands and massacre this or that prisoner. The soldiers, unacquainted with Smyrna customs, attacked any civilian wearing a fez, and a number of Smyrniot Greeks, Armenians, and Jews—who till that day had worn the common Ottoman headgear-fell victims to this error or barely escaped. The killing went on for two days, and for many days after not a fez was to be seen in the streets. The looting lasted a fortnight, and probably more of this was done by Ottoman Greek civilians than by the soldiers. Not only in Smyrna but in villages within a radius of half-a-dozen miles from the city, local Greeks—suddenly possessed of armsraided their Turkish neighbours' houses, stripped them of their furniture, and lifted their cattle. This was allowed to go on by the occupying authorities until Mr. Sterghiádhis arrived on the scene.

It is difficult to estimate the number of the killed. When the slaughter was over, my first witness visited the morgue and counted there forty unreclaimed

\footnotetext{
1 'Long live Venizelos' or 'Long live Greece.'

${ }^{1}$ British naval officers and seamen on board warships moored to the quay had to witness these atrocities at a few yards' distance. They clamoured for shore leave, in order to intervene, but leave was refused. The admiral had instructions from higher quarters to leave the Greeks a free hand when once their disembarkation had taken place. It is not, of course, suggested that the
} 
bodies in addition to parts of bodies and limbs. Before his visit, the majority had been recognised and removed for burial by their relations. For days afterwards, fresh corpses were washed up by the sea, those killed on the sea-front having been thrown into the water. At least 200 Turks in all appear to have been murdered. On the other hand, I have failed to obtain evidence that the Greek troops suffered casualties. My two Western witnesses had neither seen nor heard of any, and I have inquired in Greek quarters without result. ${ }^{2}$ This is a point of great importance, though of course it does not prove that the original shot was not fired by the Turks, for bullets do not always hit their target.

A second spontaneous outbreak, this time on the Turkish side, occurred a few weeks later at Aidin. Hearing of what had happened at Smyrna, the ablebodied Turks of the town and district broke open the arsenal where surrendered war material had been stored by the Allied control, armed themselves, and took to the mountains before the Greek forces arrived. The temporary recapture of the town by these Turkish chettés has been mentioned in Chapter VI. During the few days that they held it, they wiped out the Greek quarter. Women and children were hunted like rats from house to house, and civilians caught alive were slaughtered in batches—shot or knifed or hurled over a cliff. The houses and public buildings were plundered, the machinery in the factories wrecked, safes blown or burst open, and the whole quarter finally burnt to the ground.

authors of these instructions foresaw how the Greeks would use their licence. Yet it required little foresight to do so!

${ }^{2}$ But on this point see further, p. 393. 
Many of the women who escaped with their lives were violated, and others were kidnapped and never again heard of by their families.

When I visited Aidin eighteen months afterwards, ${ }^{1}$ I found that a large part of the Turkish quarter ${ }^{2}$ had also been burnt. All the mosques that I saw were ruined and abandoned, and there were practically no Turks left in the town. Were these all reprisals, or had some of this destruction been done by the Greeks during their first occupation? I received two contradictory answers. The members of a Western family whose honesty is above suspicion and who had been living in a house a mile or two outside the town while all these events were happening, informed me that to their knowledge the Greeks had done nothing during their first occupation to exasperate the Turkish population. The other story was that the Greek commander, finding the arsenal cleaned out, had published a proclamation demanding the surrender of a stated quantity of arms by the Turkish inhabitants within a stated number of hours, and threatening, if he did not obtain them, to fire a portion of the Turkish quarter. The requisite number of arms was not forthcoming (they had been carried out of reach) and the quarter designated was burnt down.

Whether the Turks had this provocation or not, it does not diminish the guilt of what they did themselves, nor do their atrocities justify the reprisals which the Greek troops took, during their retirement and return, in the surrounding Turkish villages as well as in the town. I afterwards met a Turkish landowner

\footnotetext{
${ }^{1}$ See 'Two Ruined Cities,' p. 148 above.
} 
from one village whose whole family had been butchered and the bodies thrown into a well. At the time of my visit, ruins flanked the railway for miles as one came into Aidin by the Smyrna train. It had needed no organisation to desolate the richest parts of the Maeander Valley. The beast had come to life spontaneously in Turk and Greek, and acted after his kind.

There were further spontaneous outrages on both sides at each revival of military operations-for example, during the Greek offensive in the summer of 1920, on which the following observations were made by the Inter-Allied Commission of Inquiry:--

'Attacks on Christians, which had become less numerous since the armistice, increased in numbers and ferocity-more particularly with regard to the Greeks—in March 1920, and even more so in June and July 1920, when preparations were being made for Greek offensives. ${ }^{1}$

'The principal excesses of which the Greeks are accused took place after July 1920, when the Greek military forces occupied the territory. ${ }^{2}$

'These excesses are attributed either to regular troops or to bands.

'When they arrived in the territory (in July and August), the regular troops attacked various Moslem villages, principally those

\footnotetext{
${ }^{2}$ On the western side of the konak.

${ }^{1}$ Cmd. 1478 (1921), p. 11, referring to the district north of Ismid.
} 
in the region east of Beicos. Inhabitants were killed, cattle carried off, and houses and even whole villages burnt. To this should be added individual offences on the part of soldiers belonging to Greek detachments, such as extortion of money, theft, violence, and murder. In the occupied regions the Greek military authorities first made numerous arrests and caused people to be summarily executed (more particularly at Beicos-Chibukli).

'A good many searches made for hidden weapons gave rise to individual offences, violence and theft. These individual offences, caused by insufficient discipline, were not usually stopped. $^{1}$

'Acts of violence and barbarism, as well as massacre on a large scale, were undoubtedly committed in 1920 by Kemalist bands, or by soldiers of the regular army, against the Christian population of the region not occupied by the Greek army, east of Yalova, north of the Lake of Nicaea, and in the region of Nicaea. ${ }^{2}$

But those spontaneous atrocities were only the first phase. They were succeeded by organised atrocities on either side as soon as the military operations became critical. The Greek organised atrocities began half-way through Aprili 1921, immediately after the Greek Army's reverse at In Önü.

\footnotetext{
${ }^{2}$ In the Ismid district. The report was written before the events which accompanied the Greek evacuation of Ismid at the end of June and beginning of July, 1921.

${ }^{1}$ Cmd. 1478 (1921), p. 10.
} 
Having for the first time encountered the new Turkish regular troops and realised the formidable character of their antagonists, they vented their anger and alarm upon the civil population behind the front, just as the German Army committed their worst atrocities in Belgium and Northern France in areas to the rear of battlefields where they had met with unexpected opposition. The Turkish atrocities against Christian civilians in 'Pontus' began early in the following June, when the Turkish General Staff were anticipating the big Greek offensive against Eski Shehir and Angora.

On both sides, these atrocities were afterwards represented as necessary and justifiable military measures against attacks by guerilla bands. The Turks declared that the revolutionary organisation of the 'Pontic' Greeks was in touch with the Greek General Staff; that the latter had supplied them with arms and even with officers; and that, as soon as the offensive started, they were to make a diversion in the Turkish Army's rear. The Greeks, for their part, declared that the Turkish villages which they had destroyed had harboured Turkish bands, which had penetrated the Greek lines and had been raiding their railway communications. Probably there was truth in both statements, for guerilla bands are always likely to be at work in such conditions as those created in Anatolia after the $15^{\text {th }}$ May 1919. This used to be the excuse of the Turkish troops in Macedonia before the Balkan War for the 'shooting up' and pillaging and burning of villages, and it is quite possible that (as the Turks allege) there was similar provocation for the atrocities against the Armenians in 1915. Only, as the last

\footnotetext{
${ }^{2}$ Cmd. 1478 (1921), p. 3.
} 
instance illustrates, such provocation generally bears no proportion whatever to the reprisals taken for it; and while the guerillas who have given it generally escape, many times their number of innocent and unarmed people suffer abominations. In fact, the provocations alleged generally turn out to be no more than welcome pretexts for the indulgence of covetousness and bestiality, and certainly this is the impression made by the evidence about the organised atrocities in the Anatolian War on either side. I have no information that they were committed in the course of fighting. The victims had almost always been disarmed beforehand—sometimes months beforehand; the crimes were committed in cold blood and the plundering was leisurely and systematic. During the first raid of Greek chettés upon Armudlu on the $19^{\text {th }}$ April 1921 (see below), kaiks sailed round the coast from the chettés' home-villages to carry away the loot, and the spoil from Hoja Deréyi-Bala was transported by trains of mules. I personally questioned ${ }^{1}$ a number of survivors from the group of Turkish villages round Fistikli about the temper of the Greek chettés during their operations. They all agreed that they were not in a state of fury or excitement. They plundered first and killed afterwards, and they sang at their work, even when they got to the killing. It was the exhilaration of a cat who has caught a mouse to play with.

A significant feature was the murder of rich men and subsequent seizure of their property. Sometimes the whole family was killed and the house burnt, to

\footnotetext{
${ }^{1}$ On board the Red Crescent S.S. Gul-i-Nihal on the $18^{\text {th }}$ June 1921.
} 
cover the tracks of the criminals. I have in my possession accounts of many such murders committed by Greek soldiers or chettés or by both together in the course of raids on villages in different parts of the Greek occupied territory. The rich often fell victims to their great possessions when the poor escaped with their lives. On the other side, I note an example from the raid of Osman Agha Kiresünlü and his chettés upon Marsovan in the last week of July 1921. In an account derived from neutral eye-witnesses, ${ }^{1}$ it is stated that a certain Sadyk Bey, Commissioner at Marsovan for the Angora Government, took the opportunity of the raid to murder two rich Armenians to whom he owed L.T. 6000. In these organised atrocities, the economic motive was certainly uppermost in the minds of those who carried them out-though when they had tasted blood, the rabies sometimes carried them away and they burnt or otherwise ruined valuable property. The political motive was also important. For the local members of the nationality in power, it was a pleasure to get rid of their alien neighbours, while the more exalted persons who armed and instigated them (playing on their covetousness for the purpose), were no doubt anxious to eliminate awkward minorities_and still more awkward majorities—in territories which they hoped to keep for their own national state. Military considerations may have entered in, but in the Yalova-Gemlik Peninsula, where I made my closest personal investigations, the evidence was against this. I do not think that bands of Turkish chettés had been at work here before the organised atrocities

\footnotetext{
${ }^{1}$ Reported by the Times correspondent at Constantinople, and published in the Times of the $26^{\text {th }}$
} 
were committed by the Greeks against the Turkish civilian population. I do not judge merely from the fact that this district was behind the front-guerillas might have crossed the lines_-but from the circumstance that during May and June isolated Christian villages were still occupied by their inhabitants, and that the military pickets and the squads of Greek kurujus (irregular guards) posted in the Turkish villages were so small that their lives would not have been safe if Turkish as well as Greek bands had been in the neighborhood. In this area, at any rate, I believe that the Greek troops and chettés had the field to themselves, and this was also the opinion of M. Gehri, the representative of the Geneva International Red Cross:--

'At the time of our investigation, the Peninsula of SamanliDagh [=the Yalova-Gemlik Peninsula] was behind the Greek front, and it has never been a theatre of hostilities since the beginning of the Greek occupation. Until March last, the region was quiet. The crimes which have come to our knowledge fall within the last two months (end of March to the $15^{\text {th }}$ May). They are subsequent to the retreat of the Greek army after the defeat of Eski Shehir [=In Önü]. Possibly they are a consequence of it."1

Since the chettés were the principal instruments (though not the principal authors) of the organised atrocities on both sides, it is necessary to explain more precisely what they were. There had always been 'economic' brigands in 
Anatolia—a straightforward profession, in which people of all local denominations and nationalities had engaged. They were the enemies of constituted authority, which had done its ineffective best to put them down. But these new 'political' chettés, though they were partly recruited from the professionals, and though their personal incentive was still loot, were in quite other relations with the civil and military authorities of their respective nations. So far from discouraging them, the authorities armed them, organised them, and gave them a free hand to accomplish results which they desired to see accomplished but preferred not to obtain openly for themselves.

The 'political' chettés were in fact a form of 'camouflage,' and, as might be expected, they were a recent institution. There was no camouflage about the klephts and bashy-bozuks who committed the atrocities of the Greek War of Independence. They were acclaimed as soldiers and patriots by their fellowcountrymen. But Westernisation imposed metaphorical as well as tailor-made black coats, and Oriental Governments admitted to the Concert of Europe had to observe its decencies. Practices still kept alive in Near and Middle Eastern countries by abnormal conditions had somehow to be reconciled with accepted Western standards. A solution was worked out in Macedonia by the independent Near Eastern nations of the Balkan Peninsula, under the stimulus of the situation created after 1878 by the Treaty of Berlin. It was simple-indeed so simple that Western observers were never deceived; but perhaps it ministered to some nascent uneasiness about atrocities among the people themselves, for they

\footnotetext{
${ }^{1}$ Gehri, op. cit., pp. 3-4.
} 
persevered in it until it became the recognised convention. The Governments merely ceased to acknowledge the agents by whom their policies were carried out. The bands sent across the frontiers were ostensibly organised by revolutionary committees, equipped by patriotic subscriptions, and recruited by self-sacrificing volunteers, and army officers exchanged their uniform for brigand fancy dress when they acted as leaders. Everybody knew that these brigands had the backing of the states whose supposed interests their activities were intended to advance, but the convention enabled the Governments of these states to remain 'at peace' with one another and with the Ottoman Empire, and to maintain diplomatic missions on the Western model in one another's capitals. This certainly postponed the more wide-spread miseries of open war, but it was more demoralising. The relation between Governments and 'komitajys' (the nickname of Western derivation-'committee-men'-by which these new-fangled gentry were appropriately called) was not only equivocal. It was in the nature of things indeterminate, and in the process of disclaiming responsibility the principals sometimes actually lost control. It was curiously like the relation between the Powers and their pawns discussed in Chapters II. and III. In this novelty, as in others, the Turks did not fail to imitate their former subjects. 'Chetté' soon became the synonym for 'komitajy' in Anatolia. Turkish 'political' chettés made their début in 1914 on the Western littoral, ${ }^{1}$ and in 1915, after being reinforced by convicts released for the purpose from the public

\footnotetext{
${ }^{1}$ See Chapter IV.
} 
prisons, they carried out the designs of the Union and Progress Government against the Armenians in every province of Anatolia except the vilayet of Aidin. The Armenian civil population was 'deported' from the villages and towns and marched off for 'internment' under the escort of uniformed gendarmes; but at the first point on their road out of range of Western observers, the chettés appeared and executed the massacre. The uniformed gendarmes arrived without their prisoners at their destination. What had happened? The chettés had waylaid them. It was unfortunate. The Ottoman Government, faithful to its tradition of clemency, had intended only to deport the seditious Armenians instead of taking severer measures; but the chettés, though outlaws, were Osmanlis. Their patriotic indignation had been too strong for them, and their armament too strong for the gendarmes, so that the Government could not be blamed for the mishap to the Armenians. The make-belief was as inept as it was disgusting, yet it was felt to be worth while. These were the precedents for the organised atrocities of 1921.

In war-time, chettés are not difficult to raise. The Inter-Allied Commision of Inquiry drew attention to the field for recruitment afforded by embittered refugees:--

'Where either side is in the ascendancy, the survivors of the other in many cases become fugitive; the men often become brigands. ...

'The members of the Commission [in the Ismid area] are under the impression that those Moslems who have become 
brigands will return to their homes and to peaceful pursuits when assured of settled conditions under Moslem administration, and that Greek brigands, if offered an amnesty, will take the opportunity of trusting the Allies in a scheme for colonisation in a Greek zone. These men appear usually to have become brigands only when driven from their homes or after desertion from Turkish military service. $^{11}$

The Greek recruiting authorities paid special attention to the Anatolian Circassians. At the time of the final subjugation of the Caucasus by Russia, something like half a million survivors of this Caucasian Moslem nation were given asylum in the Ottoman Empire. Their leaders soon made their mark in Turkish public life, but the commonalty never got on with the Turkish peasants. Their different language, customs and costume and higher standard of living were barriers, and they were as turbulent as the Kretans. There were many of these uncomfortable Circassian exiles in Western Anatolia. Damad Ferid Pasha's attempt to raise a Circassian army against the Nationalists, and the desertion of Eshref and Edhem, the Circassian chette leaders, from the Nationalists to the Greeks, have been mentioned already. ${ }^{2}$ These two deserters are reported to have laid suggestions before the Greek High Command for the enlistment of their kinsmen on a larger scale. In irresponsible Greek quarters,

\footnotetext{
${ }^{1}$ Cmd. 1478 (1921), p. 10.
} 
there was talk of imitating the Russian Cossack system and of planting a cordon of privileged Circassian military colonists round the frontiers of the Anatolian territory which Greece hoped to retain in permanence. The Ottoman Government had done this with the Circassians in a haphazard way along the desert border of Syria, but the unsuitability of the climate for Northern settlers had told against the experiment. Whether the Greek authorities really thought of repeating it on their own account it is impossible to say, but in the course of 1921 they certainly raised considerable numbers of Circassian auxiliaries, on whom the Commission of Inquiry passed the following judgment:--

'These Circassians furnish excellent semi-regular combatants, but also form bands whose poorly controlled activity admits of excesses and thus helps to perpetuate the régime of continual reprisals which is gradually ravaging and depopulating the country.'1

At the end of June 1921, a few weeks after that report was written, some of these Circassian mercenaries assisted the Greek chettés and regular troops at Ismid in the massacre of Turkish civilians, on the eve of the Greek evacuation of the town. But so far as I could discover, they played a subordinate part, and there is no warrant for making them the scape-goats for either this or any other Greek atrocity.

\footnotetext{
${ }^{2}$ See Chapter V.

${ }^{1}$ Cmd. 1478 (1921), p. 11.
} 
The majority of the political chettés raised by the Greek authorities in Anatolia, in and after April 1921, were neither professional brigands nor nonTurkish Moslems, but local Christians formerly engaged in peaceful occupations. The survivors from Turkish villages round Fistikli which had been attacked and burnt by Greek chettés in April 1921 (see below), told me that previously there had not been chettés in their district, that the relations between the Greek and Turkish inhabitants had been neighbourly, and that the leaders of the new Greek chetté bands had been shepherds and charcoal burners. ${ }^{2}$ At Yalova, several of them had been shopkeepers or petty merchants. At Gemlik, one of them owned a little factory! They were, in fact, ordinary Greek civilians who, under the brutalizing influence of the war and the encouragement of the Greek army of occupation, had girt on bandoliers, assumed an appropriate head-dress, ${ }^{1}$ and begun breaking the Sixth, Seventh, and Eight Commandments as well as the Tenth. This was, of course, the most deplorable feature in the system. Had the executants of the organised atrocities been only professional criminals or alien settlers like the Circassians, they could subsequently have been killed or driven out without compromising the innocent majority of the nationality whose

\footnotetext{
${ }^{2}$ They gave me the following names of chette band leaders from Greek villages:--From Engheré, Londi Kaptan; from Katyrly, Stylianòs; from Arnautkeui, Yokátos Yoryi ('Loaded George'), Hajji Topuz (?) oghlu ('Palmer Club's son') Panayoti, and Kumarjy oghlu ('Gambler's son') Potti (?)_ not all so very respectable after all, if their family professions were accurately recorded in their surnames.

${ }^{1}$ A sort of turban consisting of a strip of cloth, or of a bashlyk with long lappets would round the head and loosely tied. This is the national head-dress of the Laz-a Georgian-speaking Moslem tribe on the Black Sea coast between Batum and Trebizond, renowned as sailors and assassins. The Greek chetté leaders wore it self-consciously, but the Western peaked cloth cap-their
} 
authorities had employed them. But these civilians turned assassins compromised the whole nation to which they belonged. Their activities started a war of extermination between the two elements in a mixed population, and when once this had begun, it was difficult to see how the two could be enabled to live together as neighbours again. The enrolment of these chettés opened a vista of reprisals and counter-reprisals which all the diplomacy of the West could hardly arrest before it worked itself out to its horrible conclusion.

The irony of the situation was that this diabolical method of camouflage was totally ineffective. On both sides, conclusive evidence was obtained by Western observers that chettés and constituted authorities were acting in cooperation. On this point, the Inter-Allied Commission in the Yalova-Gemlik Peninsula, in their report on the $23^{\text {rd }}$ May 1921 , summed up as follows:--

'The Commission endeavoured to arrive at the causes which, in less than two months, brought about the destruction or evacuation of nearly all the Moslem villages of that part of the kazas of Yalova and Guemlek which is occupied by the Greeks.

'If events which took place at the time of the movements of the Greek army towards the end of March can explain why the villages near to the Greek line (Dijan Keu, Reshadié, Soyuljak, Bazar Keui (Turkish), and Chengeller (Armenian)) were destroyed or abandoned by reason of attack or as reprisals, the case is not parallel on the northern shore of 
the Gulf of Mudania. These latter villages were burned on the $15^{\text {th }}$ May, when military operations were but few, and without the Greek Commander having reported the particular acts of provocation, although the Commission had been at Guemlek since the $12^{\text {th }}$ May.

'A sufficient cause is doubtless presented by the agelong hatred existing between the various races, increased, in so far as the Greek soldiers and the Greek population of Guemlek are concerned, by the presence of 2000 Armenian refugees who suffered greatly at the hands of the Turks during the war, and by that of 3600 Greek refugees, many of whom witnessed the atrocities committed by the Kemalists at Fulajik, Elmalik, and Nicea [sic]. But although this hatred can explain the severity of the treatment suffered by Moslem villages, it does not appear to have been the determining factor of their destruction on so general and rapid a scale.

'A distinct and regular method appears to have been followed in the destruction of villages, group by group, for the last two months, which destruction has even reached the neighbourhood of the Greek headquarters.

'The members of the Commission consider that, in the part of the kazas of Yalova and Guemlek occupied by the 
Greek army, there is a systematic plan of destruction of Turkish villages and extinction of the Moslem population. This plan is being carried out by Greek and Armenian bands, which appear to operate under Greek instructions and sometimes even with the assistance of detachments of regular troops.

'This destruction of villages and the disappearance of the Moslem population consequent thereon doubtless has as its object to guard the flanks and rear of the Greek army against any possible attack by the population in the event of an early offensive, and perhaps even to create in this region a political situation favourable to the Greek Government.

'In any event, the Commission is of opinion that the atrocities reported against Christians on the one hand, and Moslems on the other, are unworthy of a civilised government, and that in the region occupied by the Greek army, the Greek authorities, who are alone in authority there, are responsible, and, in the region under the Kemalist régime, the Turkish authorities.'

M. Gehri, the representative of the Geneva International Red Cross who accompanied the Inter-Allied Commission and subsequently the Ottoman Red Crescent on several of their expeditions, expressed the same opinion:--

'The Mission came to the conclusion that for the last 
two months elements of the Greek army of occupation have been employed in the extermination of the Moslem population of the [Yalova-Gemlik] peninsula. The facts established—burnings of villages, massacres, terror of the inhabitants, coincidences of place and date-leave no room for doubt in regard to this. The atrocities which we have seen, or of which we have seen the material evidence, were the work of irregular bands of armed civilians (tcheti) and of organised units of the regular army. No cases have come to our knowledge in which these misdeeds have been prevented or punished by the military command. Instead of being disarmed and broken up, the bands have been assisted in their activities and have collaborated hand in hand with organised units of regulars. ${ }^{1}$

On pp. 10 and 11 of the White Paper, ${ }^{2}$ similar conclusions are recorded by the section of the Inter-Allied Commission which visited the Ismid district and reported—before the final scenes of the Greek evacuation—on the $1^{\text {st }}$ June 1921.

These general judgments can be supported by examples. My own observations at Yalova are recorded below, ${ }^{3}$ and can be corroborated by

\footnotetext{
${ }^{1}$ Gehri, op. cit., p. 3.

${ }^{2}$ Cmd. 1478 (1921).

${ }^{3}$ See 'Yalova,' p. 299.
} 
reference to M. Gehri's report. ${ }^{4}$ The co-operation between Greek chettés and military at Kapakly and Kumla was observed by both M. Gehri and the Inter-Allied Commission. I quote M. Gehri's account, because it is less accessible in the original to English readers than the White Paper:--

'Monday the $16^{\text {th }}$ May 1921.-The Bryony [the British warship conveying the Yalova-Gemlik Commission of Inquiry] proceeded to Kapakli, which had been burning since 3.0 o'clock the previous day. Here and there among the smoking ruins, a few inhabitants. The rest had fled into the mountains. Eight corpses, four being those of women. Three of them seemed to have been dead about a fortnight. The 5 others had been killed the day before. In the case of one woman, the blood was still flowing. Another woman had been killed on a mattress. The whole posture of the corpses showed that they had been killed where we found them, in their houses. Some had been mutilated.

'The survivors declared that the assassins had been Greek soldiers. The staff officer [attached by the Greek command at Gemlik to the Commission] contested their statements, and, noticing a little girl, demanded that the question should be put to her, because "in the mouths of children the truth is found." The child declared quietly and categorically that the criminals had been Greek soldiers. ...

\footnotetext{
${ }^{4}$ P. 14.
} 
'Tuesday the $17^{\text {th }}$ May.-The Commission received, on board the Bryony, the depositions of Lieutenant John Costas and Adjutant Papoultopoulos, of the $28^{\text {th }}$ Infantry Regiment, who had been in command of the detachment sent to make a reconnaissance in the south of the Peninsula, on the $12^{\text {th }}, 13^{\text {th }}$, $14^{\text {th }}$, and $15^{\text {th }}$ May. Their itinerary and time-table coincided at almost every point with the information supplied by the people of Koumla and of the burnt villages. Lieutenant Costas admitted the possibility of his soldiers having been the incendiaries. He had not considered it his duty to keep himself informed of what was happening. At Koumla landing-place, he had had 4 armed Turks arrested and shot.

'While the Bryony went to Fistikli and Armoudli, I left with the Greek lieutenant and adjutant and our Italian interpreter to identify the corpses of the four Turks who had been shot. In the course of an hour's ride we found 7 , only one of which was identified by the lieutenant as his handiwork. Asked why he had shot them when he had only had orders to arrest them, he replied: "Because I chose." The Greeks returned to Ghemlik and we to Koumla landing-place. On the way back we found 2 more corpses.

'That evening, about 5.0 P.M., we were visited at the landing-place by the brigand leader Yorgo of Ghemlik. He was armed to the teeth and accompanied by a boy and a soldier, also 
armed. They were followed by a detachment of soldiers, who took cover under the trees at some distance from the village. Yorgo boasted of having accompanied Costas's reconnaissance detachment in all its movements and of having set the villages on fire. When they left, the trio stole 3 horses from the people at the landing-place, to go up to Koutchouk Koumla. ... .

'Thursday the $19^{\text {th }}$ May 1921.-By General Leonardopoulos's orders, a divisional liaison officer brought the brigand chief Yorgo on board [the Bryony]. Yorgo declared that he had been drunk when he boasted the day before; that while he had certainly accompanied Costas's detachment in its various movements, he had only done so in the capacity of guide; that it was not he who had set fire to the villages, but Greek brigands from Yalova; and that the officer and he had seen them doing it.'1

The survivors from the villages round Fistikli told me that in their district the work had mainly been done by chetté bands of Greek civilians from the two villages of Katyrly and Arnautkeui. They had been organised and armed by the Greek authorities-partly with weapons taken from the local Turks when these had been disarmed, and partly with arms brought from Gemlik and distributed to the local Greek population by two Greek officers accompanied by a hundred soldiers.

${ }^{1}$ Gehri, op. cit., pp. 8-11. 
Greek troops had participated in the destruction of the three villages of Sultanié, Khairié, and Selimié.

On the $29^{\text {th }}$ June 1921 , my wife and I personally witnessed Greek troops in uniform committing arson without provocation along the south coast of the Gulf of Ismid. We were travelling up the Gulf towards Ismid in the Red Crescent S.S. Gul-i-Nihal, with a representative of the Allied High Commissioners on board, whose presence enabled us to pass the cordon of Greek warships. The Greek forces, which had evacuated the town of Ismid on the morning of the previous day, were retreating along the shore in the opposite direction-from east to west-towards Yalova and Gemlik. Our first intimation of their approach was the sudden appearance of two columns of smoke rising from the shore ahead of us. A little later, and a village ${ }^{2}$ burst into flames just as we came opposite to it, and at the same moment we saw that a column of Greek troops in uniform, coming from the east, had just arrived there. We were coasting only a few hundred yards from the shore, and could see the soldiers setting fire to the houses distinctly with the naked eye. Even the boats moored to the jetties were burning, down to the water-line. Later, as we looked astern, we saw new and larger columns of smoke rise from the little towns of Eregli and Karamursal, which had been intact a few hours before, when we had passed them. The head of the column had reached them and continued its operations. From our anchorage off Ismid that evening, we could see the fiery glow above Karamursal flickering far into the

\footnotetext{
${ }^{2}$ Afterwards identified as Ulashly Iskelesi.
} 
night. On the $1^{\text {st }}$ and $2^{\text {nd }}$ July we landed at Karamursal, Eregli and the skala ${ }^{1}$ of Deirmenderé, and walked up to inspect Deirmenderé itself. Everywhere the destruction had been malicious and systematic. Among the ruins of Karamursal we found two live human beings. One was an old Turkish woman named Khadija, who had been violated and beaten with rifle butts. The other was an exhausted Greek private named Andréas Masséras, belonging to the $10^{\text {th }}$ Company, $16^{\text {th }}$ Regiment, $11^{\text {th }}$ Division. I afterwards got an account from him of what had occurred. During the retreat of the $29^{\text {th }}$ June, he told me his regiment had been the rearguard-except for a detachment of Circassians only twenty or thirty men strong. The villages were all burning by the time that they reached them-a confirmation of our own observations at Ulashly Iskelesi, where we had seen the houses being set on fir by regular troops at the head of the column. At Eregli, Masséras had fallen out with sunstroke; the tail of the column passed him; he dragged himself on as far as Karamursal; collapsed there; and lay in the open till we picked him up. This again confirmed what we had seen for ourselves, that there had been no fighting during the retreat, and that the Turkish towns and villages had been burnt in cold blood, without provocation.

The collaboration of Greek troops with chettés was not confined to the Yalova-Gemlik-Ismid areas. I possess detailed accounts of raids, accompanied by massacre, in which Greek troops participated at Bashlamysh, near Akhissar, on the $24^{\text {th }}$ June 1921 , and (further south) at Tiyenli, near Manysa, on the $25^{\text {th }}$

\footnotetext{
${ }^{1}$ Landing-place, with subsidiary village.
} 
May of the same year, besides less circumstantial records and statistics from many other parts of the occupied territories.

In 'Pontus,' on the Turkish side, during the organised atrocities which began in June 1921, the relations between the Nationalist authorities and their chettés appear to have been similar. Accounts from survivors of the atrocities against the Greek minority in Bafra town and district, which were carried out between the $3^{\text {rd }}$ June and the $18^{\text {th }}$, state that the Nationalist Governor, Jemil Bey, openly organised the proceedings and that Turkish regulars and gendarmes took as much hand in the plundering, raping, killing and burning as the chettés recruited from the local Moslem civilians.

On the other hand, American eye-witnesses ${ }^{1}$ of Osman Agha Kiresünlü's raid upon the town of Marsovan in the last week of July, reported that the raid was made on the chetté leader's initiative; that the Nationalist Governor of the town had shut himself up in his house while it was in progress; and that some of the Christians whose lives were threatened were saved by some of the upperclass Turkish inhabitants. In this instance, the chettés were not local men but came from a distant and much wilder district, and the disapproval of the governor and the local notables was not surprising. At the same time, the Nationalist Commissioner Sadyk Bey apparently did participate (as mentioned above) in the crimes committed by the raiders, and local gendarmes and peasants went on looting after the chettés had gone. The Angora Government are said to have 
instituted an inquiry and to have punished several officers and officials found guilty of misconduct in connection with this raid, but no disciplinary action seems to have been taken against Osman Agha. Possibly they could not have deprived him of his office of Mayor (Beledié-Reis) of Kiresün, where his power was no doubt greater than theirs. But at least they might have struck him off their armylist, in which he had figured, and continued to figure, as a colonel. Probably the 'Pontus' revolutionary movement really was a danger to the Nationalists between June and September 1921, when they needed every regular soldier that they could muster on their western front in order to prevent the Greek Army from reaching Angora. Osman Agha's methods of repression were effective, and they could not afford to quarrel with him if he overshot the mark. Such an explanation, if correct, would not be a justification of their leniency towards him, but only another illustration of the evils which were to be expected from the prolongation of the Anatolian War.

The tactics employed in these organised atrocities on both sides need not be illustrated so fully, for there were few innovations. The indirect method known as deportation was practised on a large scale. On the Greek side, I have information of deportations from the districts of Manysa, Nif, Kasaba, Salyhly, Askhissar, Alashehir, Kula, Ushaq, Torbaly, Bayndyr, Tiré, Ödemish, Aidin, and Nazylly_ in fact, from all over the interior of the occupied territory. The following is an instance from the town of Alashehir itself. Rif'at Bey, the Turkish kaimakam or governor under the Greek occupation, laid a report on outrages committed by

\footnotetext{
${ }^{1}$ An account based on information from them was communicated to the Times by its
} 
Greek troops before the Greek commandant five times over, and the fifth time received a promise of attention. Hearing no more of it, however, he submitted a second report, which received no acknowledgment. Thereupon Rif'at Bey sent copies of both reports with a covering letter ${ }^{1}$ to a Western Consul-General at Smyrna. The Greek authorities discovered what he had done, put him under arrest, and deported him—with the Hakim, Mufti, and twenty-five other Turkish notables of the town-as a 'prisoner of war.' During their march, the party had to pass the night in the open in all weathers. They were known to have arrived at Smyrna and to have been shipped away, and that was the last news of them. I possess precise accounts of similar deportations from fourteen particular towns and villages, the largest recorded number from any one place being fifty, and the average about thirty. The dates range from the $13^{\text {th }}$ April 1921 to the beginning of July, when my informant had ceased to collect information-not because deportations had ceased to occur, but because he was exposing himself, in recording these and other outrages, to imminent personal danger. The deportees were sometimes murdered by their escort on the way-for example, a certain Sultanhissarly oghlu Ömer Efendi, deported on the $20^{\text {th }}$ April 1921 from Köshk, near Aidin, whose corpse was afterwards found lying in the road, while the fate of his fourteen fellow-deportees was unknown. In the Aidin district, the deportees' houses were sometimes looted and their womenfolk violated, after their removal, by Greek officers and non-commissioned officers. At Tiré, a

\footnotetext{
Constantinople correspondent and published on the $26^{\text {th }}$ October 1921.

${ }^{1}$ Kaimakam's official letter No. 84 of $9^{\text {th }}$ May 1921 in local archivesof Alashehir Sanjak. My source of information was not the consulate in question.
} 
certain Isbartaly Hajji Suleiman and another Turkish notable were deported for having given shelter to two refugees from a group of eighteen villages ${ }^{1}$ in the neighbourhood, which had been looted and burnt on the $28^{\text {th }}$ June.

In these deportations, the Greek authorities adhered to their policy of striking at the Turkish upper class. No doubt they hoped to establish their ascendency more rapidly over the peasantry if their national leaders were bodily removed. The Turkish deportations, on the other hand, like those of the Armenians in 1915, seem to have been made wholesale, without distinction of class. They were partly provoked by the operations of the Greek Navy along the Black Sea littoral. A landing was feared in connection with the main Greek offensive and with the 'Pontus' revolutionary organisation in the Turkish rear. On the $27^{\text {th }}$ July 1921 , the Greek and Armenian Section of the British High Commission at Constantinople informed me that they had been receiving very bad reports; that the deportations were attended by great suffering and in some cases by massacre; and that they were occurring in Southern Anatolia as well as in the 'Pontus' area.

Unfortunately, deportations were far from being the worst of the organised atrocities. They were surpassed by the destruction of villages and 'shooting up' of towns. This 'direct action' usually began in the outlying parts of a district. The small coverts were drawn first, and, like skilful 'beaters,' the chettés herded the survivors into the central village or town, where they could be disposed of

\footnotetext{
${ }^{1}$ I obtained the names of twelve of these villages.
} 
conveniently. This tactic was followed by the Greeks in the Yalova-Gemlik Peninsula, and by the Turks in the region of Bafra. The first stage was generally effected quickly, and second at leisure. Having taken the edge off their appetite for loot and blood, the chettés played cat-and-mouse with their remaining victims. They subjected them to a merciless blockade, killing any who ventured out to work in the fields. On occasional dark nights they raided and withdrew and raided again, each time doing a little pillaging and murder. At length they pounced; there was the final massacre; the village went up in flames; and a month's not unprofitable sport ended in the elimination of the rival nationality from that particular area. Before giving examples, I must state my conviction that, as a general rule, both the Greek and Turkish authorities were able to stop this sport at any moment if they chose to do so. The village of Ömer Bey, on the hillside above Gemlik, was effectively protected by the presence of two Greek guards in uniform, though the chettés had wiped out all the villages a mile or two further north. Similarly, after the withdrawal of the Greek garrison and the Christian civilians, the Nationalist military authorities were able to preserve the Armenian village of Baghchejik, opposite Ismid across the head of the Gulf. The local Turkish chettés who occupied it had been instructed that arson was not to occur, and the instruction was obeyed. ${ }^{1}$ These instances of discipline were admirable,

\footnotetext{
${ }^{1}$ Half-a-dozen houses were set on fire by local Turkish civilian pillagers during the night of the $29^{\text {th }}$ June 1921, while the chette detachment stationed in the village was absent on a reconnaissance. The fire was extinguished by the chettés when they returned.
} 
but they increase the responsibility of the authorities in the far more numerous cases in which they refrained from exercising their power.

The drawing of the outlying coverts may be illustrated from the treatment of the six little Turkish villages round Fistikli, about which I obtained details from survivors. Here there were no wholesale massacres. From Selimié, for instance, all 300 inhabitants escaped to Kapakly, Narly, and Karaja Ali, and did not perish till these latter places were overwhelmed on the $15^{\text {th }}$ May (see above). At Ihsanié, only 5 were killed and 2 wounded out of 100; at Sultanié, 1 killed and 1 wounded out of 56; at Mejidié, 2 missing out of 250. Only at Khairié half the population were known to have been killed in this first phase, but that was premature. A murder or two was generally sufficient to terrorise the villagers into abandoning their homes and fleeing either to the forests and mountains (where many perished of exposure and starvation) or to the larger centres. (My own informants had been rescued by the Red Crescent after two months' precarious shelter at Armudlu.) The 6 villages $^{2}$ round Fistikli were evacuated in rapid succession during the week ending the $18^{\text {th }}$ April 1921, and then ransacked and burnt by the chettés at their ease.

In the cat-and-mouse play, which was the next stage, there were variations. Samanly, for example, was one of the only two survivors among the seventeen Turkish villages in the district of Yalova. It harboured the persons and property of refugees from the neighbouring villages which had been destroyed. 
Yet Samanly itself, though closely blockaded, got off with a single raid accompanied by only one murder. Between the $15^{\text {th }}$ April 1921 -the date of that event-and the $5^{\text {th }}$ June, when the Red Crescent evacuated the population, the final catastrophe appears to have been averted by an understanding between the head Greek kuruju, a cheerful ruffian called Ormanjy Yoryi ('Forester George'), and the leaders of the Greek chettés. The Greek authorities preferred to allude to Yoryi as a 'garde champêtre,' but he could hardly have done his job if he had been anything so respectable. When we attempted to evacuate the villagers' cattle, it appeared that more than half the animals (as well as an astonishing number of paper liras) had passed into his ownership during the previous six weeks as 'gifts in return for protection.' No doubt a percentage of this was passed on to the chettés to purchase delay, and they must have felt themselves cheated when we evacuated the village under their noses. ${ }^{1}$ But the villagers had profited—-though for a substantial 'consideration'—by the Forester's diplomacy.

At Armudlu—a large, mixed village near the tip of the Yalova-Gemlik Peninsula, to which I made two three-day visits in June 1921 with a Red Crescent expedition—-the Greek and Turkish communities had previously been on good terms. During the European War, when the Greeks had been deported to Brusa, the Turks had looked after their property for them; and under the Greek military occupation the local priest—Papa Photi of Imraly—did his best for the Turks, who talked of him as their saviour. It is true that his flock eventually

\footnotetext{
${ }^{2}$ From Lutfié, the sixth, only two families (=fifteen persons) had reached Armudlu. The fate of the rest was unknown, but they may have found refuge elsewhere.
} 
petitioned the Patriarchate to remove him for this reason, but, down to the evacuation, they treated their Turkish neighbours with less then the usual inhumanity. The chettés who harried Armudlu came from Katyrly, Arnautkeui, Koiru, Gemlik and Yalova. Taukju oghlu ('Poulterer's son') Khristo of Katyrly, Stylianòs of Arnautkeui, and Dhimitri of Koiru were the names that I noted.

Khristo had some bowels of compassion. During the battle of In Önü (when the chetté bands were being formed) he visited Armudlu on the pretext of buying olives and warned a Turkish acquaintance, Hilmi Reis, to flee, because they intended to burn down the village. About a month later, Khristo visited Armudlu again, and the following day one hundred chettés-the same who afterwards burnt Kapakly, Narly, and Karaja Ali in the sight of the Inter-Allied Commission—duly arrived. ${ }^{1}$ They took money from all the Turkish inhabitants, and the local Greek kuruju, Mumju oghlu ('Chandler's son') Kocho, who acted as their go-between, informed the notables that they would have to find L.T. 3000 . But this time the chettés were not in earnest. Though the money was not forthcoming they went away after killing only two people.

A week later they came again—arriving from Gemlik with a party of soldiers under an officer. The chettés themselves were dressed up in Greek uniforms, but were recognised by their faces. The Turks barricaded themselves in their houses. The raiders took twelve head of cattle and again retired.

\footnotetext{
${ }^{1}$ On the last day they were hiding behind the nearest wood, but did not pounce, owing to the presence of Allied officers with the Red Crescent Mission.

${ }^{1}$ Khristo did not accompany them.
} 
The Turkish community then complained to the headquarters of the Greek Tenth Division at Gemlik, and a permanent picket of thirty soldiers was posted in Armudlu under a second-lieutenant, but this safeguard increased their afflictions. The chettés came more than ever, and the officer made personal raids on the Turkish households at night, extorting money, valuables, and women. In time, the girls learnt to escape by the back-door as he arrived, but he used to beat the head of the household when he did not get what he wanted. A woman named Eminé, seventy years old, who refused to put him on the tracks of her granddaughter, was so cruelly beaten by this hero and his men that she could not move for several days. When the Inter-Allied Commission visited Armudlu on the $17^{\text {th }}$ May, she tried to show them her wounds, but before she could get in touch with them she was driven back into her house by Greek soldiers with fixed bayonets. From first to last many women were violated, for the officer took a different one each night.

After the visit of the Commission, this officer was replaced, and the situation improved. But the maintenance of the Greek picket (including their consumption of rakí) was charged entirely to the Turkish section of the community; the chettés hovered in the offing; and when the Red Crescent offered them the opportunity, the Turkish inhabitants of Armudlu were glad enough to leave their homes and become refugees.

They had not fared so badly as the Turks of Fistikli, who had had to receive three parties of 'guests' in succession-a band of chettés from Katyrly, another from Arnautkeui, and a detachment of fifty-five Greek regulars from 
under an officer. In June 1921, when I obtained my information, the village was being governed by the officer and the two chetté leaders in joint committee. The villages had to supply their followers with a ration of bread, and on the first evening women had been violated and money and other property stolen. Still, up to date my informants had heard of no murders at Fistikli, the place had not been burnt down, and most of the inhabitants were still there, though the mukhtar had got away to Constantinople. Fistikli had so far escaped the final catastrophe.

These places that I have just described were exceptions. They were the few places in that particular area where Turkish inhabitants survived to be evacuated. Elsewhere, sooner or later, the cat pounced and the extermination was completed. I never witnessed the last act except on my voyage to Ismid. It was seldom performed when Western observers were in the neighbourhood, though at Kapakly, Narly, Karaja Ali and Kumla the Inter-Allied Commission was (literally) in at the death. From survivors of the destruction of Gedelik (a village between Gemlik and Pazarkeui) and of Upper and Lower Hoja-deré (twin villages above Engheré, on the north coast of the Yalova-Gemlik Peninsula) I obtained detailed accounts, which can be published hereafter if necessary, while the account previously cited of Osman Agha's exploits at Marsovan may serve as an illustration on the other side. But I shall not reproduce these horrors here. The West has become sufficiently familiar with their counterparts since 1914 for me to leave them to my readers' imagination.

I must, however, say something about the events which preceded the 
voluntary withdrawal of the Greek Army from the town of Ismid, at the end of June 1921. During the year that the Greek occupation of Ismid had lasted (July 1920 to June 1921), the war of extermination had gone to such lengths, and the local Greek civilians had compromised themselves so deeply by participation, that the entire native Christian population took its departure with the troops. Naturally they felt savage. Their brief ascendency had cost them their homes; they had had to leave their immovable property behind; and though they had had time for preparations and the Greek authorities had provided shipping, their prospects were forlorn. They vented their rage on their Turkish civilian neighbours, while they still had them in their power. The villages east of Ismid were evacuated first, and the Turkish peasants with their ox-carts were commandeered to transport the departing Christians' possessions. When we landed at Ismid about thirty-five hours after the completion of the evacuation, the streets leading to the jetties were heaped with the wrecks of these carts and the water littered with the offal of the oxen, which had been slaughtered on the quay in order that the flesh and the hides might more conveniently be shipped away. Corpses of Turkish carters-murdered in return of their services—were floating among the offal, and one or two corpses of Turkish women. In the town itself, the Turkish shops had been systematically looted-the Christian shops being protected against the destroying angel by the sign of the cross, chalked up on their shutters over the owner's name. One Turkish and Jewish quarter in the centre of the town had been set on fire, and the fire had only been extinguished after the Greeks' departure by the exertions of the French Assumptionists (who 
have a College at Ismid, and covered themselves with honour on this occasion). ${ }^{1}$ Cattle had been penned into the burning quarter by the incendiaries in a frenzy of cruelty and had been burnt alive, and the smoking ruins were haunted by tortured, half-burnt cats. The mosques had not only been robbed of their carpets and other furniture, but had been deliberately defiled. In the courtyard and even in the interior of the principal mosque, the Pertev Mehmed Jamy'sy, pigs had been slaughtered and left lying. A general massacre had been prevented by the French liaison officer stationed at Ismid, who started patrolling the streets in company with the commander of a French destroyed as soon as the killing began. But at 1 P.M. on Friday the $24^{\text {th }}$ June, three and a half days before the Greek evacuation, the male inhabitants of the two Turkish quarters of Baghcheshmé and Tepekhané, in the highest part of the town, away from the sea, had been dragged out to the cemetery and shot in batches. On Wednesday the $29^{\text {th }}$ I was present when two of the graves were opened, and ascertained for myself that the corpses were those of Moslems and that their arms had been pinioned behind their backs. There were thought to be about sixty corpses in that group of graves, and there were several others. In all, over 300 people were missing - a death-roll probably exceeding that at Smyrna on the $15^{\text {th }}$ and $16^{\text {th }}$ May 1919.

\footnotetext{
${ }^{1}$ They sheltered several thousand Turkish civilians on their premises until the Greeks left, and when I visited them they were giving asylum to the one or two Christian families that had not got away.
} 
These details are as horrible as those which I have withheld, but I have recorded them with a purpose. The rabies that broke out among the Greeks at the moment of quitting Ismid was a warning of what might happen on a much larger scale of the statesmen whose policy was responsible for this war of extermination in Anatolia should altogether fail to retrieve the mischief which they had made. If the Greek military occupation were terminated by agreement, and the consequent change of régime—whatever it might be-were effected under neutral auspices, the catastrophe might be averted. But if hostilities were still going on at the time when the Greeks, with their taghmatarkhs and their sindaghmatarkhs, their khorofilakì and their armostís, one and all, bag and baggage, cleared out from the province they had desolated and profaned, then the horror which I have deliberately described was almost bound to be repeated through the length and breadth of the occupied territory, from Brusa to Aidin and from Eski Shehir to Smyrna.

\section{YALOVA}

[Narrative written at Constantinople on the $1^{\text {st }}$ June 1921.]

Our steamer anchored opposite Yalova, a few hundred yards from the shore, about 2 P.M. on the $24^{\text {th }}$ May, and at first sight there seemed nothing wrong with the place. The row of neat houses along the sea-front was undamaged. The crops were green on the low hills behind the town, and the woods were green on the little mountains in the background. The landscape was almost ludicrously English. Our first boat put off with the three Allied officers 
attached to the expedition and the representative of the Geneva International Red Cross, who had acted on the commission of investigation the week before. We saw them walk up the jetty, receive the salute of a Greek guard of honour, and pass round the corner of the konak (Government Offices). As soon as the boat came back, my wife and I followed. We had a general permission from the Greek High Command to visit the Brusa front. We showed our papers to the sentry and found ourselves waiting in the Kaimakam's (Turkish governor's) office on the ground floor, while the official members of the party were talking with the Greek commandant, Captain Dhimítrios Papagrigoríu, upstairs. The konak faced away from the sea on to an open space. There were cafés on the other side, with Greeks, Armenians, and a few Turks sitting in front of them and looking on, while groups of Greek soldiers stood about idly in the open.

As we waited, the first event was a rumour from a Greek source. Three women had been killed that morning, on their way down from a village, by Turkish chettés (brigands engaged on 'political' work)! In a few minutes, a strange procession arrived and halted in front of our window-an araba (native carriage) bearing the dead bodies of three women in Greek dress, neatly laid out and covered with flowers. The procession was conducted by a Greek priest, who took part in all the subsequent scenes. He spoke Turkish fluently, and we were informed that he had arrived in Yalova two days before the Inter-Allied 
Commission of Inquiry and had made inflammatory speeches. ${ }^{1}$ Certainly his conduct was inflammatory as we saw it.

Whether intentionally or not, he marshaled the corpses into the square at the moment when the Red Crescent officials (who landed after us) were coming on shore. If the feelings of the Greek crowd had been aroused, as they well might have been at the sight of three of their women newly killed, the Red Crescent officials would have been put in some danger. But the crowd remained strangely calm. Not anger or horror or pity but curiosity seemed to be the dominant emotion. Our presence near the ground-floor window of the konak was not at first perceived. The priest gave a swift upward glance at the first-floor balcony, to make sure that the Allied officers were still closeted with the Greek commandant, and then rapidly directed his assistants to arrange the sheets on which the bodies were laid, so as to show the blood-stains to the best advantage. Several times over this ghastly drapery was rearranged to improve the effect. if was like some obscene milliner dressing her shop window. The upward glances became more frequent, the expectancy of the crowd more intense. Then the officers came out and the spectacle was duly presented to them.

Were the women really Turks or Greeks? To judge by the attitude of the crowd, they were not their compatriots. And who had killed them? I do not see how any Turk could have killed anybody in this district at this moment. The local Turkish civilians are disarmed and terrified, and though Yalova is close to the

\footnotetext{
${ }^{1}$ He was said to be an emissary from the Oecumenical Patriarchate. He told me himself that he
} 
front, none of the Greeks stated to me that Turkish chetté bands were operating behind the Greek lines. They ascribed the atrocities vaguely to chettés, but the only chettés we saw were Greeks. These Greek chettés, as well as the Greek soldiers, are going about the country in small parties, and the Greek and Armenian villages are still intact, while fourteen and a half Turkish villages out of sixteen ${ }^{1}$ have been destroyed. I cannot prove that what we witnessed was a fraud staged for our benefit, but it seems to me probable that the dead women were Turks and that Greek chettés had killed them.

But the afternoon was getting on, and we had much work before us. The Red Crescent had been given to understand, before the steamer started, that the Greek High Commission at Constantinople had consented to the evacuation from the Yalova district of all surviving Turkish inhabitants and refugees who wished to leave. (Since my return to Constantinople, I have called at the Greek High Commission and ascertained that this was the case.) We were prepared to bring away at least 1000 people, and we now asked the Greek Captain for an escort in order to visit the villages and bring the people down. At once he interposed an objection. Only refugees from villages burnt or otherwise destroyed might be evacuated, not inhabitants of surviving places—namely, the two villages of Samanly and Akkeui, which we proposed to visit, and Yalova town. An unseemly argument began, in the presence of the crowd of soldiers and civilians. It was adjourned to the Captain's room, but he alleged categorical orders to this effect from his superior officer General Leonardhópulos, commanding the $10^{\text {th }}$ Division. 
The utmost that we could prevail on him to do was to telegraph to the general at his headquarters at Gemlik, stating our belief that the Greek High Commission had authorized the removal of all Turkish civilians wishing to leave, and asking for orders in this sense. In the meantime we set off to make an inspection of the two Turkish villages—Samanly and Akkeui-which still survive out of the original sixteen of six weeks ago.

Our start for the villages of Samanly and Akkeui was not easy, for our request for an escort drew a string of objections from Captain Papagrigoríu. It was half a day's journey; we should not get back till after midnight; the road ran through a wooded ravine infested by brigands; he could not guarantee our security. We looked at our watches and our maps. It was about five o'clock. We reckoned that we should be back by ten (as we were), and that there was a moon. At last the Captain gave way. He called the sergeant of a patrol and gave him private instructions in his office, and we marched off with the sergeant and about ten men.

At Samanly, the first village, we found the male inhabitants lined up to receive us, and several ruffianly-looking fellows, armed to the teeth but not in uniform, standing guard over them. These, we were told, were Greek 'rural guards.' It soon became apparent why they were present. We put the question to the assembly: 'Do you want to stay or go?' and it was received in silence. At last one man answered: 'I want to go,' but the rest still held their tongues. Then the official members of the party went off to the mukhtar's (headman's) house to

\footnotetext{
${ }^{1}$ Actually, fifteen and a half out of seventeen.
} 
talk to him privately (he told them that the village had recently been pillaged, and that they could not work in their fields without danger to their lives), while I went round the assembled villagers and took down the names of each and the number of his family (I got a record of 132 living inhabitants and 35 living refugees from places already destroyed, and I am going back to call the roll and see if they are still alive). Then I made the soldiers and 'rural guards' stand back, and asked again, very quietly: 'Do you want to stay or go?' Then one and all they answered: 'We want to go! Take us with you; take us! We are afraid.' Their terror was unmistakable, their wish was not open to doubt. They loved the homes they would be leaving, but they would abandon everything if they could save their wives' and children's lives and their own.

At Akkeui, a bigger and evidently once prosperous village, the terror was even more intense. The mukhtar being down at Yalova, we went to see the hoja (Moslem ecclesiastic) in his house. He was a refugee from a destroyed village who had taken the place of the hoja of Akkeu, previously killed by the chettés, and was looking after the mosque. (Though a refugee, and thereafter able to leave under General Leonardhópulos's orders, he stuck to his post and refused to come with us.) 'Do you want to stay or go?' 'I cannot speak for the others, but I think they want to go.' 'Why do you want to go?' Silence. 'Are you afraid?' 'Yes, we are afraid.' 'Are you afraid of chettés?' 'Yes.' 'Of Greek chettés?' 'Yes.' As he said this, the hoja drew nearer and spoke in a whisper, almost sinking on to the floor. 'Are you also afraid of the Greek soldiers?' A very long pause, and at last a faint 'No.' 'Have bad things been happening in Akkeui?' 
'Yes. A week ago, or perhaps as much as nine days (later we learnt from an independent source that it was at any rate less than a fortnight) the Rumchetteleri (Greek chettés) came into the village and killed sixty people [out of about 400]. Some are buried in the open square through which you have just come, others on a little hill between the two mahallas [quarters] of the village.' It was terrible to leave that poor hoja and his fellow-villagers with the night coming on, the 'rural guards' standing by with their rifles and bandoliers and evil countenances, and the Greek chettés (some of whom had ridden out of Yalova ahead of us) lurking somewhere in the neighbourhood. But the official members of the party had to get back to learn what orders had been telegraphed by General Leonardhópulos, and after consultation we decided that it would be unsafe, as well as ineffective, for the rest of us to stay there alone. We had begun to realise how seriously the Greek troops and chettés were out of hand.

Next morning the British and Italian officers visited the two villages again, taking with them members of the Red Crescent Mission. This time they made a list of surviving inhabitants, and of refugees from other places, at Akkeui, as I had done at Samanly the night before, and here also we shall return to call the roll. This time, too, two boys (about thirteen or fourteen years old) found courage to show them the traces of the Greek chetté raid which had occurred about nine days before. They led them to another quarter of the village behind some trees. The houses were gutted, the window and door frames removed (a common phenomenon in the present devastation of Anatolia), the furniture broken open and thrown into the street, and in the backyards there were newly-made graves. 
Out of the round figure of sixty people killed on that occasion, which had been given us by the hoja, our party obtained forty-nine individual names.

The courage of the two boys who exposed these damning traces was wonderful. The whole population was overcome by strain and terror, and while these boys were acting as guides they were being dogged by the 'rural guards.' Whether or not they came within the scope of General Leonardhópulos's telegram, they had, if possible, to be got away, and the party brought them down to the shore. We got one of them on board, and he is now in safety. The British military policeman who accompanied us was keeping his eye on the other till his turn came to get on board, but he was called away for a moment on other business, and when he looked round again the boy had gone. We could find no trace of him, and, though we have his name, we have little hope, when we return, of finding him alive. ${ }^{1}$ Indeed, what proportion shall we find of these terrorised villagers who, because they were inhabitants of still undestroyed villages, were prevented by General Leonardhópulos's express orders from embarking on the Red Crescent steamer? We are working with all our might to save them. If we fail, we shall know, from our records, who have been killed, and shall be morally certain as to who have killed them.

On the morning of the $25^{\text {th }}$ May, those of our party who did not make the second journey to Samanly and Akkeui attempted in various ways to bring Captain Papagrigoríu to reason. Having with me a letter of recommendation

\footnotetext{
${ }^{1}$ Happily we did.
} 
from General Papulas, the Greek Commander-in-Chief in Asia Minor, and having received much kindness from him, I drafted a telegram to him explaining the situation and requesting permission for the surviving inhabitants of Yalova, Samanly, and Akkeui to embark, as well as the refugees. I then sought out the Captain in the café, asked the favour of an interview with him in his office, and handed him simultaneously my credentials and my telegram. Would he be so kind as to send the telegram off? 'The Commander-in-Chief says that you are a Philhellene! In this telegram you are destroying Greece!' 'I think it is to the interest of Greece that the Commander-in-Chief should be informed of what is happening here.' 'I will not send it.' 'Very well, Kýrie Lokhayé ('Mon Capitaine'). I am not an enemy of Greece or acting out of malice, and I did not want to go out of my way to make this telegram public, but now I shall have to send it publicly through the Eastern Telegraph Company at Constantinople.' (I have since done so and received an affirmative answer.)

Meanwhile, Captain Papagrigoríu had been behaving worse than I had realised. He had already gone back on the terms presented in General Leonardhópulos's telegram the night before, and had announced that even the refugees from the burnt or destroyed villages were not all to be evacuated. People from certain villages which he mentioned by name were to be kept back—first of all on the ground that these were still intact, but when we brought evidence that they were burnt, he shifted his ground or gave no reason at all. $\mathrm{He}$ was particularly stubborn over two villages-Ghajyk and Yortan. It was clear that he had some special reason for this. A second condition was that refugees 
resident more than two months in a still existing village or in Yalova were to count as old inhabitants of their new place of residence and were to stay behind-that is, if a family had been homeless and destitute for more than two months, it was to be kept in this condition! These points were discussed between the Captain and those official members of our party who had not gone up to Akkeui and Samanly to bring down the refugees whom we had found there the night before. The Captain was obdurate, and the representative of the International Red Cross made him a formal protest in the name of his Society. The Captain replied that he was merely carrying out his orders, and that, if he had had the means, he would have looked after the refugees and have provided a hospital for them! The allegation of superior orders, which Captain Papagrigoríu repeatedly made, is of serious importance. If true, it implicates General Leonardhópulos, the commander of the $10^{\text {th }}$ Division, and my impression is that the two telegrams received by the Captain from the General during our stay at Yalova (the second I shall mention later) did stiffen him in his resolve to let the smallest possible number of his victims escape from his grip. Moreover, I have absolutely trustworthy first-hand accounts (though here I have not yet been a witness myself) of the same atrocities being committed simultaneously in other parts of the peninsula—-towards Gemlik and the western extremity—where Captain Papagrigoríu is not, but General Leonardhópulos is, in control. Before this article 
is printed, I hope to have met the General himself. ${ }^{1}$ Meanwhile, I will finish the story of what I have already witnessed.

Before these interviews with the Captain were over, the refugees had begun to gather on the beach. It was incredible how quickly they flocked in. (Akkeui was nearly two hours' distance on foot from the Yalova jetty.) They brought just themselves and their families, and whatever they could carry off at a moment's notice. A few had a cow or a calf or some poultry, or boxes loaded on ox-carts. Most had only the bundles of bedding which they could carry on their backs. Most pitiful of all were the women with children, whose men were dead and who had no one to help them. As we reckoned it out afterwards, there were something like 500 persons huddled together there like terrified animals, in sight of the steamer, and looking to us to get them into safety. The British and Italian lieutenants returned with the last arrivals. The Christian civilians (Greek and Armenian) and the Greek soldiers gathered round, half-mocking and halfmenacing. The sinister priest sidled up. Captain Papagrigoríu presented himself, and the leaders of the Greek chetté bands now openly paraded in his company! I secured the names of five: (1) Kosti of Constantinople; (2) Kosti of Elmalyk; (3) Thomas of Elmalyk; (4) Khristos; and (5) Mihal, both the latter being from the village of Hajji Mehmedin Chiftligi (Hajji Mehmed's farm). I have already mentioned $^{1}$ that one of them stood at Captain Papagrigoriu's elbow during the

\footnotetext{
${ }_{1}^{1}$ General Leonardhópulos was almost immediately transferred to another post.

${ }^{1}$ In a previous telegram not reprinted here.
} 
subsequent proceedings, acting as his 'interpreter' and advising him as to which individual refugees should be passed or kept back.

The actual embarkation lasted seven hours. It began at midday on the $25^{\text {th }}$ May and continued till about seven in the evening, when Captain Papagrigoríu, after the receipt of a second telegram from General Leonardhópulos, absolutely refused to let us take any more persons on board. By that time we had succeeded in embarking about 320 out of a total of something like 500 collected on the beach, and of between 1300 and 1500 (adding inhabitants of surviving places and refugees from destroyed places together) whom we had really been authorised to evacuate by the instructions previously conveyed by the Greek High Commissioner at Constantinople (as he has since stated personally to me) to the Greek military authorities. During those seven hours we had to wrestle for their lives, not only family by family but person by person. Captain Papagrigoríu not only kept back the very few men of military age, as was reasonable; he struggled to retain in his power every individual, however feeble or defenceless or old. He separated (I have instances vividly in my mind) wives from husbands and mothers from children.

The proceedings began with a fresh argument as to whether certain categories of refugees should now be excepted or not from the number of those to be liberated. This ended in the dispatch of a second telegram to General Leonardhópulos, and eventually in the receipt of a second reply from him. As I have said, this reply appeared to stiffen Captain Papgrigoríu in his resistance. Fortunately it arrived very late in the afternoon. 
Meanwhile, we started to claim individual cases, and an indescribable confusion arose. The Captain stormed and gesticulated; we argued and expostulated; the soldiers standing at the entrance to the jetty kept on turning back persons whom the Captain had already passed for evacuation; the soldiers and the Captain shouted at each other; both soldiers and Christian civilians crowded in upon the refugees and whispered in their ears (we learnt afterwards that they had been telling them that we intended to throw those who embarked into the sea, half-way between Yalova and Constantinople!); the priest glided in and out; the Christian women looked on and gloated (we took a photograph of them laughing at the scene); the refugees sat numb and patient till their turn came to pass muster, and then the women trembled and sobbed.

I can only mention one or two of the incidents that crowd into my memory. At one moment, I heard a woman call and saw her pointing to her husban, who was being led away by a chetté leader from the shore into the town. I ran after them, led the man back by the hand, and returned with another member of our party to bring the chette before the Allied officers for an explanation. We had a scuffle with him. A Greek officer rushed up from the café and beckoned to the Greek and Armenian crowd; they threw themselves between us, and our chetté ran like a hare down the street. I do not know with which of the five gentlemen I have named I had the honour to make acquaintance, but the leaders are recognizable by the sort of cloth turban they wear. They have borrowed it from the Lazes, a Moslem tribe who do brigandage in Anatolia for their living. The 
object of this (a mean trick) is to be mistaken for Moslems, so that their atrocities may be put down to the other side.

At another moment, some one came on shore from the steamer with a message that they had seen through their field-glasses a woman struggling to show herself at the window of a house facing the sea, and soldiers forcing her back. We rushed along to the house indicated; several soldiers ran away, and others looked on sullenly while the woman emerged timidly from the door and was conducted by us to the jetty. The house from which she came was next door to Captain Papagrigoríu's.

When the second telegram from General Leonardhópulos arrived, the Captain refused to allow the embarkation to continue, and we insisted on taking the names of those refugees (nearly all from Ghajyk and Yortan) who still remained on shore. The Captain and his subordinate officers offered more opposition to this than to any other request we made to them. They suggested every pretext for frustrating us. The Captain offered to guarantee the safety of these unfortunate people on his word of honour! Finally he consented that the list should be taken down by the English military policeman attached to the Allied officers, who had come out less than two months ago and knew neither Greek nor Turkish. We agreed, and, calling up the heads of families one by one, I spelled out to the policeman the name of each, the village he came from, and the number of individuals in his household, while a Greek lieutenant screamed to me to go away. We accounted for 134 persons out of something less than 200, and then the Greek officers brought up soldiers and literally drove the rest away, 
declaring (which was untrue) that they were not refugees from destroyed villages, but inhabitants of Yalova town.

The final scene was the most pitiable, perhaps, of all. We had got off all the people whom we had rescued to the steamer, on lighters, and were now gathered on the quay, with a crowd of Greek soldiers between us and the people abandoned on the shore, when we saw two old men standing in a paralysed attitude on the jetty. Their wives had been kept back, and they would not leave without them. Rallying for a last encounter with the Captain, we went on shore again and hunted out and rescued these poor women. Yet other families were separated, by pure malignity, perhaps for ever. Next morning, when our steamer was lying at anchor between Scutari and Seraglio Point, we found a very old woman on board with several small children in her care. Their mother-her daughter—had been with them on the beach, but the Greeks had prevented her from embarking, and we had learnt of it too late.

The following is a list of the villages burnt or otherwise destroyed in the Yalova district. I myself heard Captain Papagrigoríu state that a number of these places had been burnt, and I have completed the list from other sources. I have not yet been able to visit the sites of these places, but the presence of refugees from them, and their testimony, convince me that they have in fact been destroyed. Nearly all this destruction appears to have taken place during the last six weeks, and Captain Papagrigoríu only mentioned one place-Ghajyk—as having been destroyed as a consequence of military operations. I infer that the 
remainder (like one of the quarters of Akkeui, within nine days of our visit) have been wiped out by Greek or Armenian chetté bands.

\section{LIST OF VILLAGES DESTROYED IN THE YALOVA DISTRICT}

\section{DURING APRIL AND MAY 1921}

Original

Name of Village.

1. Reshadié

2. Ghajyk

3. Derekeui .

4. Sultanié

5. Karakilissé

6. Yortan

7. Kirazly

8. Syghyrjyk .

9. Pashakeui .

10. Kürdkeui .

11. Uvez Punar

12. Gökché Deré

13. Orta Burun

14. Güllük

15. Chalyjakeui
Number of Houses.

400

100

40 to 60

10 (variant 40)

40

40 to 60

60

80

80 to 90

100

50 to 60

30 to 40

40

50 to 60

40 to 50
Number of Houses

Burnt.

All.

Half.

All.

All.

All.

All.

All.

All.

All.

All.

All.

All.

All.

All.

All.

Also the farm called Shukri Efendi Chiftligi.

NOTE.-The district covered by the above villages, together with Akkeui 
and Samanly, is less than a quarter of the total area of the YalovaGenlik Peninsula, the boundaries of which, on the land side, roughly coincide with the road from Gemlik to Yalova via Pazarkeui.

\section{THE AREA OF THE ORGANISED ATROCITIES}

It is important to establish whether the organised atrocities described in Chapter VII. were confined to comparatively small areas or were of general occurrence in the Anatolian territories respectively controlled by the Governments of Athens and Angora.

The region called 'Pontus' in North-Eastern Anatolia, where, after the armistice, the Greek minority started a revolutionary movement for an independent republic, and where organised atrocities were begun by the Turks in June 1921, more or less coincide with the Ottoman vilayet of Trebizond together with the adjoining Sanjaks of Samsun and Amasia. This is a small fraction of the total Nationalist territory, but unhappily the Turkish atrocities against minorities were not confined to these districts. By the $27^{\text {th }}$ July 1921, the British High Commission at Constantinople had received reports of the deportation of Christians further south. (See pp. 291-2 above.) These deportations were probably connected with the Nationalists' military operations against the French in Cilicia, and, if they were, the victims would mostly have been Armenians.

In this connection, the disasters brought upon the remnant of the Ottoman Armenians by the Anatolilan War deserve attention. It is true that there would in any case have been trouble in China, owing to the irresponsible policy of the 
French authorities, who tried at first to lessen the burden of their regular army by partly garrisoning Cilicia with the Armenian volunteers ofo the Légion d'Orient. They even permitted the Armenians to raise and arm irregular bands. If the Armenians took this opportunity to revenge themselves upon the local Turkish population for what they had suffered (principally from other Turks) ${ }^{1}$ in 1915 , they can hardly be blamed. ${ }^{2}$ The French, who exposed them to the temptation and afterwards allowed them to suffer for having yielded to it, have more to answer for. In fact, this French attempt to play off the Armenians against the Turks in Cilicia was of a piece with the British statesmanship that sent the Greeks to Smyrna. At the same time, it is almost certain that if the Greeks had never landed at Smyrna, the Cilician campaign and the consequent atrocities at Hajin and elsewhere on the Turkish side would not have occurred. It was the Greek landing that created the Nationalist Movement and goaded the Turks into a renewal of hostilities against the Allies on all fronts. Thus the Armenians who were massacred at Hajin, as well as the Greeks of 'Pontus' and the Turks of the Greek occupied territories, were in some degree victims of Mr. Venizelos's and Mr. Lloyd George's original miscalculations at Paris. This is still clearer in the

\footnotetext{
${ }^{1}$ During the deportation of the Armenians in 1915, the Turkish civil population displayed more human feeling in Cilicia (as far as the evidence goes) than in any other province. (See Miscellaneous No. 31 (1916), p. 652.)

${ }^{2}$ During the Cilician campaign, the Nationalist forces massacred Armenian non-combatants at Hajin and elsewhere, while the Armenians paid off past and present scores against the Turks in Adana and other places temporarily under French occupation. After the French evacuation and the exodus of the majority of the Christian civil population from Cilicia, I learnt this latter fact independently from two competent and trustworthy Western sources, who cited good evidence for it. This shows the exodus in a new light, when taken in conjunction with the circumstances of the Greek evacuation of Ismid.
} 
case of those Armenian civilians who were robbed, violated, murdered, or evicted during and after the Turkish invasion of the Republic of Erivan in the autumn of 1920. Kiazym Kara Bekir Pasha's operations had a military object directly connected with the Greek War. The Nationalists were obtaining munitions from the Russians, as the Greeks were at that time from the Allies, but the Black Sea route was precarious and it was desirable to open communications overland. The Erivan Republic was a barrier. Kara Bekir broke it down. Thus the Turkish atrocities against the Armenians in the Caucasus and Cilicia after May 1919 had the same genesis as the war of extermination in other parts of Anatolia, though they do not fall within the scope of this book.

The extent of the Greek organised atrocities has been disputed. After their occurrence in the Yalova-Gemlik Peninsula had been proved conclusively by the publication of the Inter-Allied Commission's Report, there was an attempt in some quarters to make out that the crimes thus exposed, which could no longer be denied and which it was impossible to excuse, were at least exceptional. I took pains to investigate this question, and arrived at the opposite conclusion, although my first piece of evidence appeared to point the other way.

The large Turkish village of Ömer Bey stands conspiculously on the hills overlooking Gemlik from the south-east, above the south side of the valley that runs up from the head of Gemlik Gulf to the Lake of Isnik. During our first visit to Gemlik with the Red Crescent, a Greek picket was posted across the mule-path leading up to Ömer Bey from Gemlik town, but, being bored by the interminable obstructiveness of the Greek military authorities, who kept our mission waiting for 
instructions from Smyrna which never came, my wife and I amused ourselves on the $4^{\text {th }}$ June 1921 by taking a walk which brought us to Ömer Bey from an unpicketed direction. It was a good opportunity to discuss the situation freely with the mukhtar and other notables, and we learnt from them the curious fact that conditions (map illustration)

\section{THE DANGER LINE OF ÖMER BEY}

were completely different north and south of the village. Southwards, they could go out in small parties and work all day in the fields with comparative impunity, and so could the inhabitants of other Turkish villages lying in that direction. To venture out northwards, on the other hand, meant almost certain death. Even on the high-road in the valley bottom, a few hundred yards below and visible from where we stood, some of their people had been murdered by Christian chettés, and across the valley not a Turkish village survived. There was a definite 'danger line,' running north of Ömer Bey from the Gulf of the Lake.

At the moment, I was puzzled by this information. It was a fresh indication of what was evident already—-that the atrocities which had been occurring north of this line, in the Yalova-Gemlik Peninsula, for the previous seven weeks, were being executed on some plan-but an explanation only presented itself at the end of the month, when the Greek forces retreating from Ismid successively evacuated Yalova town and the entire Yalova Peninsula, and came to a halt along the very line which the people of Ömer Bey had pointed out to me. The coincidence threw light on the connection between the atrocities and the military 
operations. The Greek troops had gone to Ismid the year before to please the Allies, but their obligation to remain there had been cancelled by the Allies' declaration of neutrality; the reverse at In Önü had demonstrated the danger of an unnecessary dispersal of forces; and a withdrawal from Ismid was a rational preliminary to the projected summer offensive. These considerations must have suggested themselves in April, as soon as King Constantine had overhauled his General Staff, ${ }^{1}$ and, after elaborate preparations, ${ }^{2}$ the retreat was ably carried out between the $25^{\text {th }}$ and $30^{\text {th }}$ June 1921 . Ten days later, the offensive duly followed, but while on the principal front the Greek Army pushed forward to Eski Shehir and the bend of the Sakkaria, they did not attempt to reoccupy any territory on the Marmara. The line to which they had previously retreated in this quarter (that is, the 'danger line' of Ömer Bey) was in fact the most advantageous that they could hold as a military front, and they stuck to it. But it was also the line at which the atrocities committed in the evacuated districts, during the two and a half months before this local retreat, had found their limit. If the atrocities north of this line had been less systematic, or if the new front had only temporarily coincided with it, the coincidence would have been little to build on, and, even as it is, it does not amount to a proof. But it does suggest very strongly that the Greek military authorities, when they decided to simplify and shorten their Marmara front after the battle of In Önü, determined at the same time to

\footnotetext{
${ }^{1}$ See Chapter VI., p. 235, above.

${ }^{2}$ Which included the evacuation of the Christian civilians from the Ismid area and the temporary occupation of Karamursal, in order to secure a line of retreat by land.
} 
devastate the country that they intended to abandon, and accomplished the devastation (by the methods described in Chapter VII.) before they executed the retreat. At any rate, on this hypothesis the organised atrocities which started on the Yalova-Gemlik Peninsula in the middle of April, the events which accompanied the evacuation of Ismid towards the end of June, and the incendiarism committed on the $29^{\text {th }}$ June along the coast from Deirmenderé to Karamursal, ${ }^{1}$ fall into place as parts of a consistent programme. The object of the atrocities, on this showing, was to exterminate the Turkish inhabitants of districts which it was no longer convenient for the Greek Army to hold. They were a 'political' corollary to a military move. On the other hand, the Turkish villages south of the projected new front were preserved provisionally as potential sources of food-supplies, transport-animals, and labour for the Greek Army. They were still in the Army's power, and could be destroyed later, if and when a further military retirement became necessary. This would explain why the line marked out in April, and eventually taken up at the end of June, for the new local front, had impressed itself during the intervening period upon the consciousness of the people of Ömer Bey as the line to the north of which the Turkish population was being exterminated, while it was being spared to the south of it.

\footnotetext{
${ }^{1}$ The Greeks could not devastate this strip of coast at the same time as the Yalova-Gemlik Peninsula, for they only held it for about five days, immediately before the retreat along it took place. Previously it had been in the hands of a force of Turkish chettés, who intervened between the Greek forces at Yalova and those at Ismid. The Greek communications with Ismid had been by sea.
} 
Personally, I find this explanation convincing, and if it hits the mark, it more than justifies the pronouncements made by the Inter-Allied Commission and by M. Gehri regarding the responsibility of the Greek authorities. Such a decision, affecting as it did the areas of two Divisional Commands, ${ }^{1}$ must have emanted at least from the Corps Command at Brusa, if not from the Army Command at Smyrna. On the other hand, though this would, if proved, confirm the worst suspicions against the Greek authorities as regards their conduct in the districts north of the line, it might by itself create a presumption that, in the far more extensive occupied territories south of the line, similar atrocities had not been organised. The 'danger line,' after all, had been a 'safety line' for Ömer Bey and for the Turkish villages immediately south of it. Unless there were evidence to the contrary, the same immunity might be supposed to prevail elsewhere.

During my travels in the hinterland of Smyrna the previous winter, I had been informed of isolated atrocities, from which my informants had already inferred a plan on the part of the Greek authorities for the extermination of the Turkish population. At the time, I had dismissed this inference as wild and unproven, but after what I had seen in May and June 1921 it naturally recurred to my mind, and at the beginning of August I revisited Smyrna to make investigations. On this visit I not only found conditions in Smyrna City changed greatly for the worse, but I obtained accounts of organised atrocities all over the interior, beginning at the same date as the oroganised atrocities on the Marmara

\footnotetext{
${ }^{1}$ Tenth Divisional Headquarters at Gemlik and Eleventh at Ismid.
} 
and affording multitudes of little 'undesigned coincidences,' besides the broad general resemblance, with the events that had come under my personal observation and that have been described in Chapter VII.

Though in these cases I was unable to check the information personally, as I had done on the Marmara, I believe it to be true, apart from the fact that it came to me from a trustworthy source,$^{1}$ for the three following reasons: (i) The situation of the Turks in Smyrna City having become what could be called without exaggeration a 'reign of terror,' it was to be inferred that their treatment in the country-districts had grown worse in proportion - that is, had become obviously very much worse, since it is a well-known fact that, in the Near and Middle East, conditions are never so bad in large semi-Westernised towns as in rural districts.

(ii) There was the coincidence of date. (iii) There were the 'undesigned coincidences' of detail.

This is not the place for a full presentment of my Smyrna information, but the following summary will give a sufficient idea of it:--

ORGANISED ATROCITIES, SOUTH OF THE ÖMER BEY 'DANGER

LINE,' IN TERRITORIES ALREADY UNDER GREEK OCCUPATION BEFORE THE OFFENSIVE OF THE 10 ${ }^{\text {TH }}$ JULY 1921.

(i) Akhissar District-

\footnotetext{
${ }^{1}$ Which for obvious reasons I am not at liberty to name at present.
} 
12 villages (names specified) affected, that is:

4 villages destroyed, with pillage and massacre;

4 villages pillaged, with massacre;

4 villages from which massacres along were reported;

(ii) Soghanderé District-

25 to 30 villages (names not specified) pillaged, inhabitants massacred;

(iii) Gördez and Kaiajyk (east of Akhissar)_

$14^{\text {th }}$ June 1921: both places pillaged and burnt, inhabitants massacred;

(iv) Between Akhissar and Manysa-

82 villages (names not specified) more or less completely pillaged;

(v) Tiré-Bayndyr-Ödemish Districts-

60 villages pillaged and some of then burnt, 18 of the latter being in the Tiré District; these were attacked on the $28^{\text {th }}$ June 1921 (12 names specified); the survivors fled to the mountains;

(vi) Aidin District-

14 villages (names specified) pillaged, women violated, men massacred; of these, 10 were attacked simultaneously on the $2^{\text {nd }}$ May 1921 and the survivors fled to the mountains.

\section{II} ORGANISED ATROCITIES, SOUTH OF THE ÖMER BEY 'DANGER 


\section{LINE,' COMMITTED SUBSEQUENTLY TO THE GREEK}

OFFENSIVE OF THE $10^{\text {TH }}$ JULY 1921.

(i) Aidin District-

50 more villages destroyed by the beginning of October 1921;

(ii) Kyzylja (a village about 15 miles south-east of Smyrna City)— 145 out of 150 hours burnt in September 1921;

(iii) Field of Operations during the Kiutahia-Eski Shehir and the Sakkaria Offensives-

Details unknown to me, but the Greek Army is reported to have carried out systematic devastations, particularly on the retreat from the bend of the Sakkaria to Eski Shehir, in addition to the incidental destruction caused by ‘legitimate warfare.'

(iv) Since the beginning of 1922-

See speech delivered by Lord St. Davids, at the halfyearly meeting of the Ottoman (Aidin) Railway Company, on the $31^{\text {st }}$ March and reported in the Times of the $1^{\text {st }}$ April 1922; further (regarding occurrences on the $14^{\text {th }}$ February 1922 at Karatepé, near Köshk, in the Aidin district), a letter, dated the $9^{\text {th }}$ March, from a Turkish correspondent of mine at Smyrna, which was 
published in the Times of the $6^{\text {th }}$ April 1922.

VIII

\section{NEW FACTS AND OLD VIEWS}

IN the last six chapters, a number of recent events relating to Turkey and Greece have been discussed in order to illustrate the problem of 'Westernisation' introduced in Chapter I. After this detailed and in parts painful survey, it is time to seek conclusions of wider interest and greater permanence than the events themselves. If my presentation has been right, certain general facts have emerged.

The public of the Western Powers on the winning side in the European War have refused to perform military service or to pay taxes on anything like the scale necessary for the execution of the programmes-mapped out during the War by their respective Governments in a series of secret agreements-for the resettlement of the Near and Middle East. 
The Governments, crippled by this unforeseen curtailment of their power, have tried to save part of their programmes by employing as pawns the local Governments and nationalities, which are more directly interested and therefore less unwilling to make sacrifices in the Near and Middle East than the Western public. This move has been a blunder. In the upshot, the Western Governments have retained less control over the Eastern situation than if they had simply accepted their constituents' verdict and abandoned their programmes after the armistice.

Greece—the principal Near Eastern pawn—has proved as incapable as Turkey (or for that matter any Western country) of governing well a mixed population containing an alien majority and a minority of her own nationality.

The Turks have now become infected with the Western idea of political nationality as thoroughly as the Greeks. This idea is partly a destructive force, especially when transplanted into the foreign environment of the Near and Middle East. On the other hand, simply because it is a Western idea, its acceptance by a non-Western people offers the basis for a modus vivendi between their particular non-Western form of society an Western civilisation. It is an implicit abandonment of the claim, hitherto tacitly cherished if not openly advanced by Middle Easterners as well as by Westerners, to impose their own institutions not only upon uncivilised populations but upon other civilised societies.

The Turks have proved themselves impregnable in the interior of Anatolia. Having successfully resisted the maximum military effort of Greece, they are a fortiori capable of resisting the less earnest will of Western Governments and 
nations to impose military, financial, and economic controls (of the kind specifie in the Treaty of Sèvres), to maintain the Capitulations or the rights of bondholders, to enjoy old or acquire new commercial concessions, or to protect native minorities. While the Treaty of Sèvres reduced Ottoman sovereignty to a minimum on paper, Turkey, within her national limits, has become more independent de facto than she has ever been since she signed the Treaty of Kuchuk Kainarjy with Russia in 1774.

The latest attempt of Greece to take further territories by force from Turkey has had no constructive results to set against its flagrant destructive effects, and can have no such results, because there are no longer any even approximately homogeneous Greek populations under the Turkish rule to be liberated. The only positive consequence has been and must be the extermination of minorities on either side, and even of local majorities, where these have been brought temporarily under the military occupation of the enemy state.

These facts are all phenomena of the fundamental process of 'Westernisation,' and illustrate one or other of its two leading features: the indifference of Western minds towards non-Western societies and the omnipresence of the Western factor in non-Western affairs. But they are more interesting and permanent phenomena than the ups and downs of diplomacy and war. The most important new element in them is common to them all, and can be summed up in a single formula: the likenesses between the positions of the Greeks and the Turks have now become greater than the differences, in regard 
to what has long been the governing factor in the lives of both peoples-namely, their respective relations to Western civilisation.

If this formula is true, as I believe it to be, the moral for Greece and Turkey is evident. With a common major problem to solve, they have an identical interest in composing their ancient quarrel—not in order to wage joint warfare against the West (a motive for co-operation which has influenced Moslem and Hindu extremists in India), but in order to leave one another a free hand to work out their particular modus vivendi in their own way. The shadow of the West has been causing increasing discomfort to both peoples, and the Janus-character of recent Royalism in Greece and Nationalism in Turkey betrays their perplexity. Turkish Nationalism is at once the acceptance of a Western idea and a revolt against Western domination. In the same way, the Modern Greeks have twice taken kings from Western dynasties in order to secure for Greece a place in the family of Western states. 'Nay, but we will have a king over us, that we also may be like all the nations.' And yet King Constantine, the son and successor of the second of them, has become popular with his subjects as a symbol of their national resistance to Western encroachments upon the independence of their country.

Both feel the pressure of a problem greater than their local animosities, but a good understanding is not easy for them to attain. When the formula of political nationality is applied to mixed populations where nationality is hard to disentangle from profession or class, an irreducible residuum of minorities is bound to be left on the wrong side of the definitive frontier lines, and this 
residuum is a fruitful cause of estrangement. Each nation fears that its own hostages in the other's territory may be ill-treated, and that the other's hostages in its own territory may undermine its sovereignty, and such expectations have a fatal tendency to realise themselves. Some solution for this problem of minorities has to be found before relations between Turkey and Greece can be expected to change for the better.

Any solution, to be successful, must satisfy the amour proper and set at rest the anxieties of either country. The former point ought to be met by reciprocity in the treatment of minorities, on lines recognised as compatible with national sovereignty by Western states. Neither party can feel humiliated by being asked to endow minorities with rights which the other party is being asked to grant at the same time, and which Western states have granted already. From this point of view, the minority treaties recently signed by Germany, Austria, Techecho-Slovakia, Poland, and Hungary, as well as by Jugoslavia and Rumania and by Greece herself, offer a good diplomatic starting point. But the crux of the minority problem is not to establish rights on paper, but to make sure that they are operative-in other words, to establish guarantees.

One practical guarantee is created by the fact that, wherever the lines of demarcation between the national states of the Near and Middle East may finally be drawn, the respective hostages in the hands of each state will be comparable in number. At the time when there were some millions of Greeks, Armenians, and Bulgars under Ottoman government and few or no Turks under the rule of an independent Greek, Armenian, or Bulgarian state, the Turks had no reciprocal 
advantage to gain by giving guarantees to their non-Turkish subjects. But when the Near and Middle East arrives (if it ever does arrive) at a new political equilibrium on the basis of nationality, there will probably have been about as many Turks brought under Greek, Bulgarian, and Armenian sovereignty as nonTurks left under Turkish. None of the states concerned will be able to safeguard their minorities abroad except through the goodwill of the ruling majority, and they can only secure that goodwill by conceding on their side what they ask for on the other.

A second guarantee (not to be under-estimated because it is impalpable) is moral pressure. The callousness of the Near and Middle Eastern nations during the past century towards their hostages in one another's hands is a reproach under which they will suffer until they show a different spirit. Again and again, the independent sections of these nations, in pursuing territorial ambitions, have deliberately exposed to the gravest dangers minorities which could not benefit even if those ambitions were realised to the full. Indeed, the tragedies of minorities have sometimes been hailed by their more fortunate kinsmen with barely concealed satisfaction as political windfalls, because they have blackened the reputation of the rival nationality. Such an attitude towards minorities is inhuman, and nations claiming admittance into the concert of Western states must make it clear by their actions that they are genuinely concerned for their minorities abroad and are even prepared, in the interests of these minorities, to make sacrifices of sovereignty at home, so long as identical sacrifices are made by the other parties. Western public opinion, if it is exerted in this sense upon all 
Near and Middle Eastern peoples with equal energy and sincerity, might be far more efficacious than its traditional partisanship has allowed it to be in the past.

The most essential guarantee, however, is the elimination of fear. No nation will treat minorities well if it believes that they menace its vital interests, and the history of the Near and Middle East during the past century has given all parties good reason to regard minorities in that light. The subject minority of one decade has not infrequently become the dominant minority in the next, and sometimes (by such methods as have been described in Chapter VII.) the local majority in the following generation. Minority rights, and the guarantees of those rights, have often been the leverage by which these changes have been brought about, and the majorities that have suffered by them have not unnaturally been filled with bitterness and suspicion. It may be stated as a general law that the protection of minorities is incompatible with instability of frontiers. The abnormal instability which was no conspicuous a feature of Near and Middle Eastern history during the last century certainly benefited the comparatively homogeneous populations that succeeded in changing their allegiance. Greeks in the Morea and the Islands, for example when liberated from the Ottoman Empire, were enabled (after a gradual recovery from the shock of the operation) to advance towards happier conditions of life, without destroying the happiness of a corresponding number of Turks. But the scattered kindred minorities paid the price by incurring the resentment of the respective majorities among whom they lived, and the persecutions grew fiercer as the process began to affect the territories inhabited by the minorities themselves, to which the dominant 
majorities felt that they had a just title on the very principle of nationality invoked by the minorities against them. This was an inevitable corollary of the remapping of the East into national states, and could only be stopped either by the stoppage of the process itself or by its completion. Now that the latter is in sight, the stabilisation of frontiers has become not only desirable but practicable.

Statesmanship should take every measure calculated to create in the minds of the several Near and Middle Eastern nations the expectation that the frontiers now drawn will be permanent, and that the instability of the past century has come to an end. It is for diplomatists to find the convincing formula. The local states might guarantee one another's frontiers by treaty, and get the instrument countersigned by the Western Powers. The expectation of stability, however created, would no doubt be unpalatable to Chauvinists safely ensconced in the national capitals, but there could be no stronger guarantee for the minorities than the persuasion of all parties that the frontiers standing between them and 'liberation,' and between the local majorities and subjection, would never be shifted in the minorities' favour. 